\begin{abstract}
CHEN, YE. Effect of Aging on the Bioavailability of Toluene Sorbed to Municipal Solid Waste Components. (Under the direction of Dr. Morton A. Barlaz and Dr. Detlef R. U. Knappe).

The bioavailability of toluene sorbed to individual municipal solid waste (MSW) component [office paper, newsprint, model food and yard waste, high density polyethylene (HDPE) and poly(vinyl chloride)(PVC)] was evaluated. Effects of sorbent decomposition on toluene bioavailability were studied by evaluating biodegradable sorbents in both fresh and anaerobically decomposed form. To determine the effect of aging on toluene bioavailability, bioavailability tests were performed for MSW components that were in contact with toluene for 1,30 , and 180 days. At the termination of bioavailability test, sequential organic solvent extraction, alkali extraction, and combustion were used to determine the fate of toluene that was not available to bacteria. Lignocellulosic waste (fresh and degraded office paper, newsprint) was subjected to enzymatic hydrolysis and acid hydrolysis to determine the effect of individual biopolymers in paper on the sorption and bioavailability of toluene.
\end{abstract}

The bioavailability of toluene sorbed to MSW components was highest in HDPE, a rubbery polymer, followed by the biopolymers and finally PVC, a glassy polymer. Except for HDPE, aging significantly reduced the bioavailability of toluene sorbed to MSW components. Relative to the 1-day aging time, the bioavailability of toluene sorbed to biopolymers was reduced by 11$22 \%$ and 12-29\% after 30 and 180 days of aging, respectively. For fresh and degraded office paper, the reduced bioavailability was a combination effect of aging and $\mathrm{pH}$ increase. Analysis of solid phase at the termination of bioavailability tests indicated that the remaining ${ }^{14} \mathrm{C}$ in sorbents was sequestered within and/or covalently bound to sorbent organic matter. Stronger association between sorbent organic matter and ${ }^{14} \mathrm{C}$ was observed during aging as less ${ }^{14} \mathrm{C}$ was recovered by organic solvent extraction and more ${ }^{14} \mathrm{C}$ was detected in the humic substances when aging time increased. Large molecular weight substances in the humic matter may form covalent binding with toluene and/or intermediates of toluene biodegradation. Humic acid had 3.7-24.3 times higher affinity for toluene than fulvic acid. 
Enzymatic hydrolysis and bioavailability tests were conducted to identify the effect of individual biopolymers in paper on toluene sorption. Toluene release from cellulose and hemicellulose was not enhanced after enzyme addition, indicating that cellulose and hemicellulose exhibited limited sorptive capacity for toluene. Lignin controlled toluene sorption and bioavailability for both fresh and degraded newsprint. Bioavailability tests showed no significant difference between toluene sorbed to biopolymer composite (fresh and degraded newsprint) and their isolated lignins. However, the presence of lignin could explain only $54 \%$ of the sorption capacity of degraded office paper. Bioavailability of toluene sorbed to degraded office paper lignin showed a higher initial biodegradation rate and mineralization extent than toluene sorbed to degraded office paper composite. Crude protein and lipophilic extractives were likely to contribute to the higher sorptive capacity of biopolymer composite. Lipophilic extractives provided highly hydrophobic environment for toluene uptake and caused the declined toluene bioavailability. 


\title{
EFFECT OF AGING ON THE BIOAVAILABILITY OF TOLUENE SORBED TO MUNICIPAL SOLID WASTE COMPONENTS
}

\author{
by \\ Ye Chen \\ A dissertation submitted to the Graduate Faculty of \\ North Carolina State University \\ in partial fulfillment of the requirements \\ for the Degree of Doctor of Philosophy
}

CIVIL ENGINEERING

Raleigh, North Carolina

2003

APPROVED BY

Dr. Morton A. Barlaz

Chair of Advisory Committee

Dr. Francis L. de los Reyes III

Advisory Committee
Dr. Detlef R. U. Knappe

Co-Chair of Advisory Committee

Dr. Michael R. Hyman

Advisory Committee 


\section{著行客 偆}

谁纵千救眼三将闲事十银赵 能死秋赵花杯实过了齿鞍客 书读二挥耳吐啖信拂杀照缦 图骨壮金热然朱陵衣一白胡 下香士㮩后诺亥饮去人马璻

白不烜邚意五持脱深千枫，吴 首噺赫郸气岳解剑藏里沓钩 太世大先素倒劝膝身不如霜 吂上梁震霓为侯前与留流雪 经英城惊生轻赢横 名行星明 


\section{Biography}

Ye Chen received her B.S. of Environmental Engineering from Beijing Polytechnic University, Beijing, P. R. China, in 1996 and her M.S. of Environmental Engineering from the same university in 1999. In the Fall of 1999, she came to the United States to start her Ph.D. studies in the Department of Civil Engineering at North Carolina State University. She received her Ph.D. degree in Aug. 2003. 


\section{Acknowledgements}

This thesis has been made possible by the support and help from numerous people. My deepest gratitude goes to:

- My advisors: Dr. Morton Barlaz and Dr. Detlef Knappe for guiding me through my doctoral study with incredible patience. Their dedication, wisdom and enthusiasm in scientific research will continue to have a huge influence on me in my future career.

- Dr. Michael Hyman, for his generous help and constructive advice. His unique insight and professional expertise made this a better work.

- Dr. de los Reyes, for serving on my committee and willingly devoting his time to assist me in my research.

- Phil Calvert, who deserves my sincere appreciation for providing support during the development of the experiment. With his excellent efforts, the most stressful and potentially miserable part of my research finally became manageable.

- David Black, for his technical assistance and daily guidance on laboratory procedures.

- Christy Smith, who taught me the basic knowledge and techniques in microbiology.

- Jerry Wicks who helped me with the preparation of more than 200 samples.

- Friends and colleagues including Lei Li, Bingyan Wu, Brenda Ress, Matt Pelton, Zhong Zhang, In Chio Lou, Kapo Coulibaly, Yong Jung, and Travis Wagner. Their help is invaluable.

On a personal level, I would like to thank:

- My parents, for their unconditional love and support.

- My husband, the most special person in my life, who loves, trusts and helps me in every possible way. 


\section{Table of Contents}

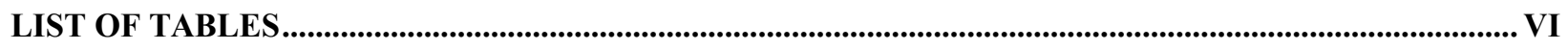

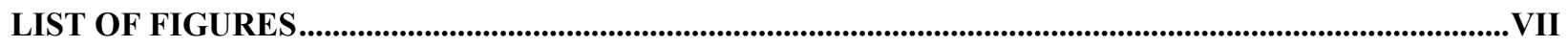

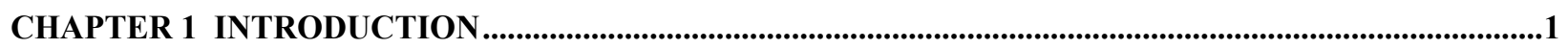

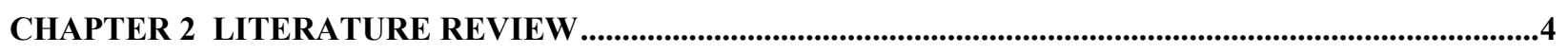

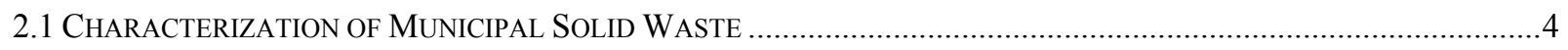

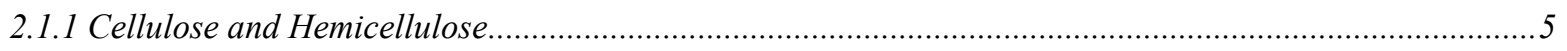

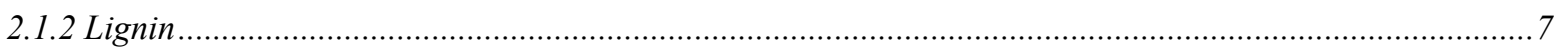

2.1.3 Poly (vinyl chloride) (PVC) and High Density Polyethylene (HDPE) ...................................................

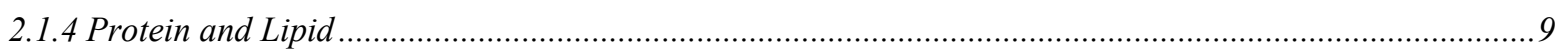

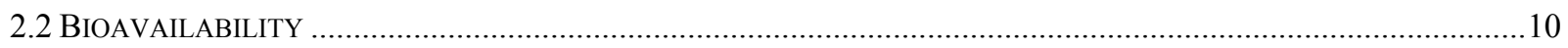

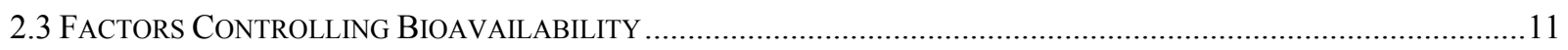

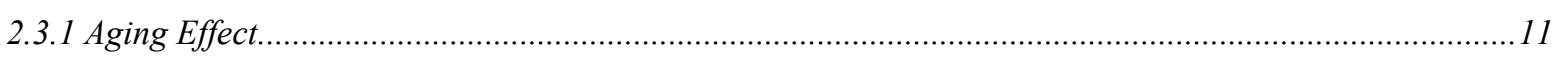

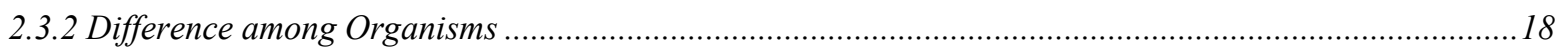

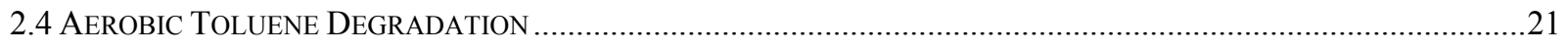

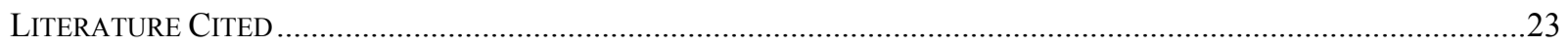

CHAPTER 3 METHOD DEVELOPMENT …................................................................................................................32

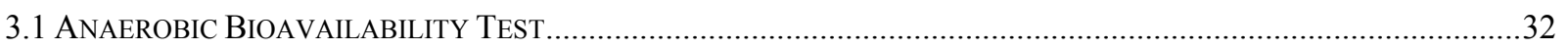

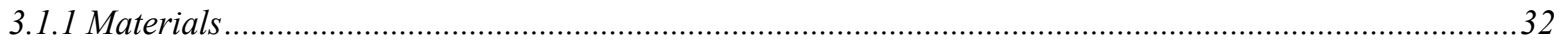

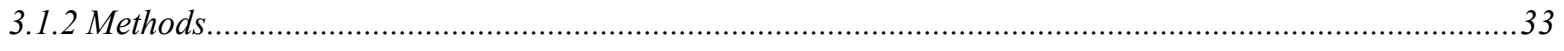

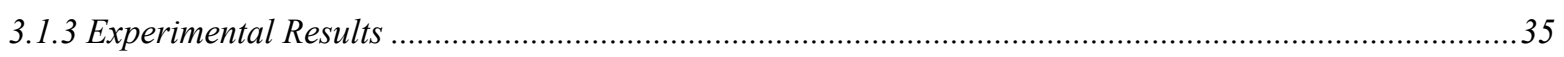

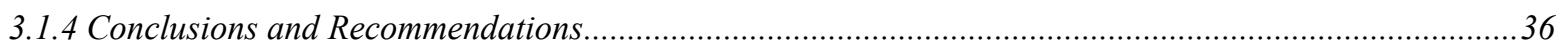

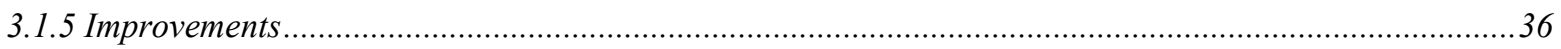

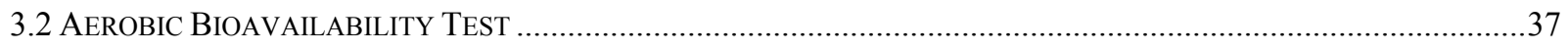

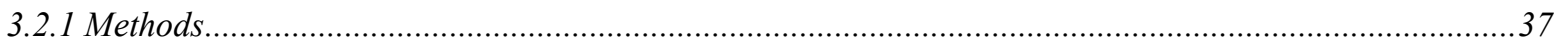

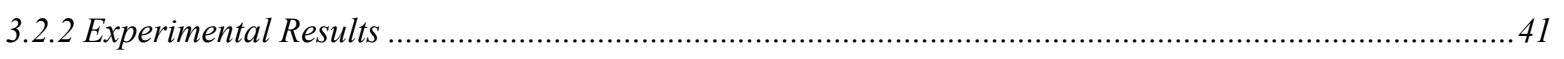

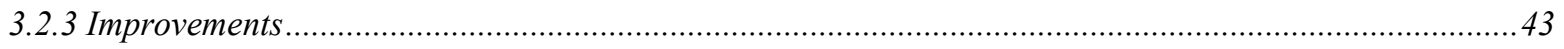

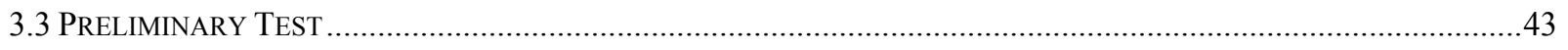

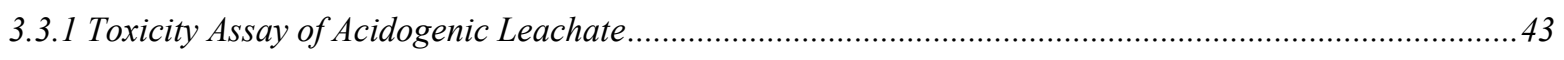

3.3.2 Bioavailability Test in Methanogenic Leachate ..................................................................................45 


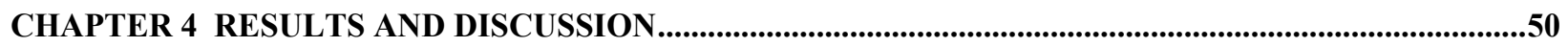

4.1 The Effect of Aging on the Bioavailability of Toluene Sorbed to Municipal Solid Waste

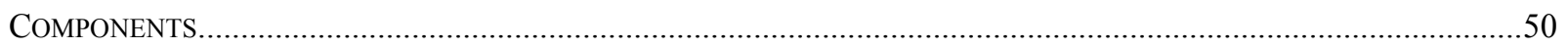

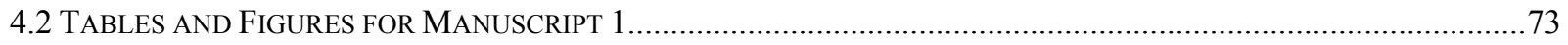

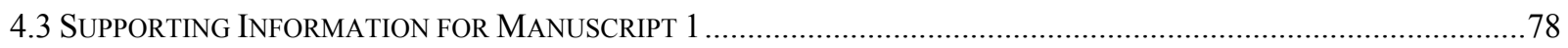

4.4 The Effect of Cellulose Plus Hemicellulose and Lignin on the Bioavailability of Toluene

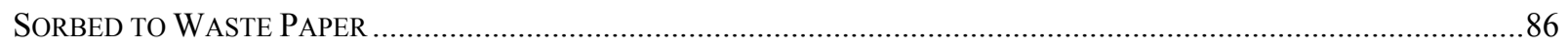

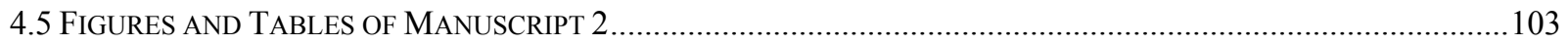

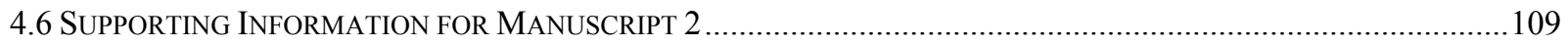

APPENDICES

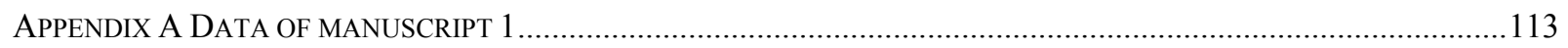

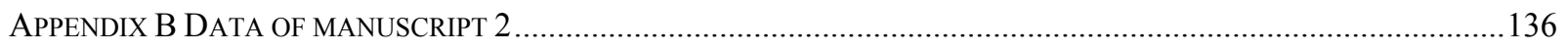

APPENDIX C RELATIONSHIP BETWEEN OPTICAL DENSITY AND CFU ..............................................................140

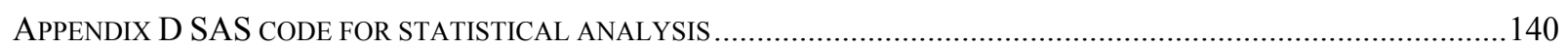




\section{List of Tables}

TABLE 2.1 COMPONENTS OF AEROBIC FUnGAL CELLULASES............................................................... 7

TABLE 2.2 COMPOUNDS SHOWn TO BeCOME LeSS BiOAVAILABLE AS A RESUlt OF AGING.................. 11

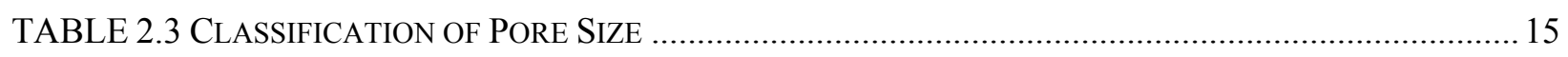

TABLE 2.4 Model Parameter for Aerobic Toluene Biodegradation by Pure Cultures ......... 22

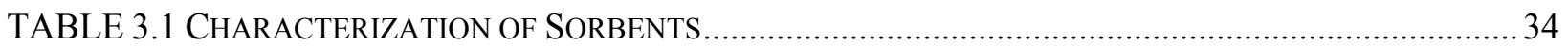

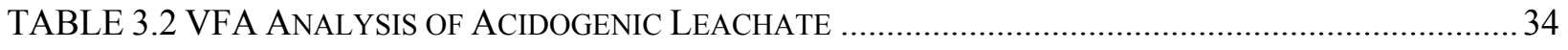

TABLE 3.3 ANAEROBIC BiOAVAILABILITY OF O-XYLENE AgED ONE MONTH ON DEGRADED NEWSPRINT .36

TABLE 3.4 COMPARISON OF TOLUENE BIOAVAILABILITY WITH AND WITHOUT GAMMA IRRADIATION.... 41

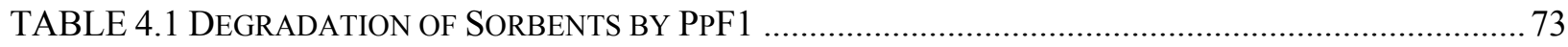

TABLE 4.2 MinERALIZATION OF TOLUENE SORBED TO MSW COMPONENTS AT 200 HRS ..................... 74

TABLE 4.3 MINERALIZATION OF TOLUENE SORBED TO MSW COMPONENTS ........................................ 74

TABLE 4.4 PH AT THE TERMINATION OF BIOAVAILABILITY TESTS FOR SELECTED SORBENTS............... 74

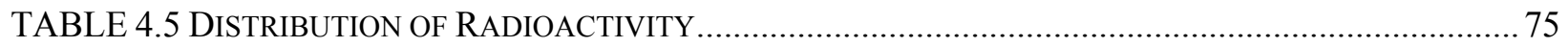

TABLE 4.6 SOLVENT EXTRACTION OF RADIOACTIVITY BY BENZYL ALCOHOL .....................................76

TABLE 4.7 Distribution of Non PuRgable OrganiC CARBon (NPOC) IN HuMiC MATTER .............. 77

TABLE 4.8 ASSOCIATION OF RADIOACTIVITY BY HUMIC SUBSTANCES ................................................ 77

TABLE 4.9 ASSOCIATION OF RADIOACTIVITY WITH HUMIN FRACTION …............................................ 77

TABLE 4.10 SORBENT COMPOSITION AND EFFECT OF PH ON ENZYMATIC HYDROLYSIS OF BIOPOLYMERS

TABLE 4.11 SORPTION OF TOLUENE TO MSW COMPONENTS AND THEIR LIGNINS .............................. 106

TABLE S4.1 SORPTION OF TOLUENE TO NEWSPRINT AND NP-LIGNIN AFTER 30 DAYS OF AGING .......... 112

TABLE A.1 MEASUREMENT OF LIQUID PHASE ${ }^{14} \mathrm{C}$ CONCENTRATION BY DIFFERENT TREATMENTS...... 113

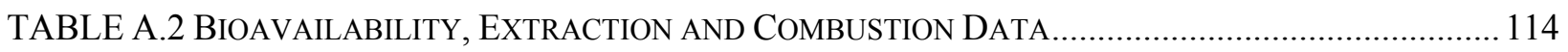

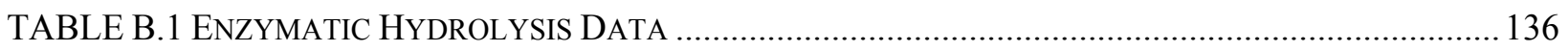

TABLE B.2 BIOAVAILABILITY OF TOLUENE SORBED TO SORBENT COMPOSITE AND ISOLATED LiGNIN 


\section{List of Figures}

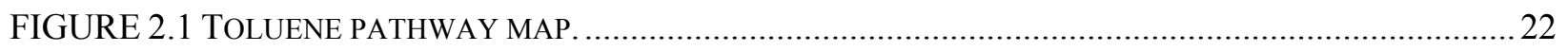

FIGURE 3.1 EXPERIMENTAL DESIGN FOR AEROBIC TOLUENE BIOAVAILABILITY TEST........................... 39

FIGURE 3.2 ANALYSIS OF RESIDUAL ${ }^{14} \mathrm{C}$ AFTER TERMINATION OF BIOAVAILABILITY TEST..................... 42

FIGURE 3.3 EXPERIMENTAL DESIGN FOR ACIDOGENIC LEACHATE TOXICITY ASSAY .............................. 44

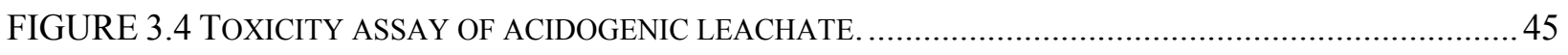

FIGURE 3.5 BIOAVAILABILITY TEST CONDUCTED IN METHANOGENIC LEACHATE. ................................46

FIGURE 3.6 ANALYSIS OF AQUEOUS PHASE AFTER BIOAVAILABILITY TEST IN METHANOGENIC LEACHATE

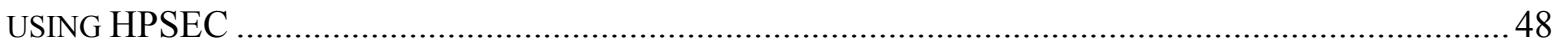

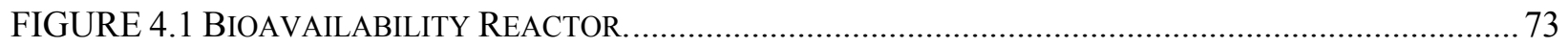

FIGURE 4.2 BIOAVAILABILITY OF TOLUENE SORBED TO MSW COMPONENTS AFTER 1-D AGING AS

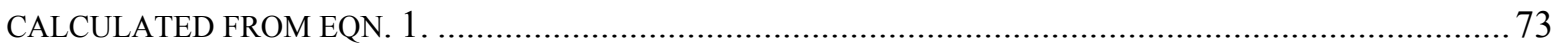

FIGURE 4.3 HPSEC CHROMATOGRAM OF HUMIC ACID EXTRACTED FROM RABBIT FOOD........................ 76

FIGURE S4.1 BIOAVAILABILITY OF TOLUENE SORBED TO MSW COMPONENT AFTER 30-D AGING.......... 78

FIGURE S4.2 BIOAVAILABILITY OF TOLUENE SORBED TO MSW COMPONENT AFTER 180-D AGING....... 78

FIGURE S4.3 HPSEC CHROMATOGRAM OF HUMIC SUBSTANCES EXTRACTED FROM MSW COMPONENT.

FIGURE S4.4 COMPARISON OF BIODEGRADATION OF TOLUENE BY PPF1 AT DIFFERENT PH.................... 85

FIGURE S4.5 COMPARISON OF DIFFERENT PREPARATION OF FRESH OFFICE PAPER BLANKS.................... 85

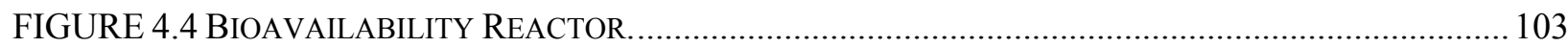

FIGURE 4.5 EFFECT OF CELLULASE AND HEMICELLULASE ADDITION ON THE BIOAVAILABILITY OF TOLUENE SORBED TO NEWSPRINT AGED FOR (A) 1 DAY, (B) 30 DAYS AND (C) 180 DAYS. ............... 105

FIGURE 4.6 BIOAVAILABILITY OF TOLUENE SORBED TO (A) FRESH NEWSPRINT, (B) DEGRADED

NEWSPRINT AND (C) DEGRADED OFFICE PAPER AND ISOLATED LIGNINS OF EQUIVALENT MASS...... 108

FIGURE S4.6 EFFECT OF CELLULASE AND HEMICELLULASE ADDITION ON THE BIOAVAILABILITY OF

TOLUENE SORBED TO OFFICE PAPER AGED FOR (A) 1 DAY, (B) 30 DAYS AND (C) 180 DAYS............. 109

FIGURE S4.7 EFFECT OF CELLULASE AND HEMICELLULASE ADDITION ON THE BIOAVAILABILITY OF TOLUENE SORBED TO DEGRADED OFFICE PAPER AGED FOR (A) 1 DAY, (B) 30 DAYS AND (C) 180 DAYS.

FIGURE S4.8 EFFECT OF CELLULASE AND HEMICELLULASE ADDITION ON THE BIOAVAILABILITY OF TOLUENE SORBED TO DEGRADED NEWSPRINT AGED FOR (A) 1 DAY, (B) 30 DAYS AND (C) 180 DAYS. 
FIGURE S4.9 BIOAVAILABILITY OF TOLUENE AGED FOR 30-D WITH FRESH NEWSPRINT AND ISOLATED LIGNIN OF EQUIVALENT MASS

FIGURE A.1 COMPARISON OF BIOAVAILABILITY OF TOLUENE SORBED TO HDPE UNDER DIFFERENT TREATMENT 113

FIGURE C.1 RELATIONSHIP BETWEEN CFU AND OPTICAL DENSITY. 140 


\section{Chapter 1}

\section{Introduction}

Despite increases in recycling and incineration, landfills remain the major waste disposal option in the United States. In 1994, approximately $61 \%$ of the municipal solid waste generated was disposed of by burial in a sanitary landfill (U.S. EPA. 1996). In the year 2000, there are around 1960 operating municipal waste landfills in the US in addition to thousands of closed sites (U.S.EPA, 2002). Unlined landfills have been shown to result in groundwater contamination (Robinson and Barr 1999; Kettunen et al. 1999; Cozzarelli et al. 2000). Approximately 15\% of the sites on the National Priority List of Superfund are municipal landfills that accepted hazardous waste (U.S. EPA. 2003). Alkylbenzenes, ketones and chlorinated aliphatic hydrocarbons are typical contaminants in ground water (Christenssen et al. 1994). Because of its water solubility and acute toxicity and genotoxicity, toluene was classified as priority pollutants by the U.S. EPA.

Landfills are physically and chemically complex ecosystems. Upon being deposited into landfills, organic compounds are subjected to a series of physical, chemical and biological processes. Active subsurface microflora is able to degrade many organic compounds, which leads towards remediation of these compounds from landfill environment. However, sorption of chemical to solids is one mechanism that prevents the chemicals from being degraded by microorganisms (Scow and Johnson 1997). Sorption also reduces the mobility of contaminants. Organic compounds may be immobilized through either diffusion into municipal solid waste (MSW), which is a reservoir of organic matter, or by degradation products forming covalent bonds with humic substances. Sorbed compounds are more resistant to microbial degradation as indicated in previous research (Pignatello et al. 1993; Lamoureux and Brownawell 1999; Alexander 2000). In the case of hydrophobic organic contaminants (HOCs), biodegradation and sorption can be viewed as competitive processes. If the biodegradation rate is rapid, the compound will disappear before sufficient time elapses for appreciable sorption. On the contrary, 
the slower the disappearance of the compound, the more time is available for sorption and loss in bioavailability to occur (Nam and Alexander 2001). Bioavailability of organic compounds is determined by the characteristics of the sorbent (Luthy et al. 1997), and the sorbate (Brusseau and Rao 1991), the physiological traits of microorganisms (Scow and Johnson 1997), and environmental factors (Rijnaarts et al. 1990).

To date, little information is available on the bioavailability of HOCs sorbed to MSW. Most studies concerning bioavailability of sorbed organics have been conducted in soils and sediments. MSW differs from soils/sediments with respect to contaminant fate and bioavailability in that (1) compared to soils/sediments; MSW has a higher organic carbon content (Eleazer et al. 1997). Glassy organic matter is hypothesized as a major factor leading to slow diffusion and reduced bioavailability of HOCs (Pignatello and Xing 1996); (2) biodegradation of lignocellulose and microbial synthesis lead to the formation of humic substances (Shevchenko and Bailey 1996). Previous investigations revealed humic substances were responsible for both sequestration (White et al. 1999) and irreversible binding of HOCs to the solid phase (Bollag et al. 1998) and (3) many studies show bioavailability is reduced by aging, a prolonged contact of HOCs to soils/sediments (Hatzinger and Alexander 1995; Nam and Alexander 1998), similar effect is expected in landfills, where long contact time can lead to the diffusion of HOCs into hard/condensed organic matter or micropores in sorbents.

Investigating the bioavailability of HOCs sorbed to MSW is of considerable importance in attempts to predict the fate and transport of these compounds and the extent of possible bioremediation in landfill. The result will also provide useful information in developing models to predict contaminant fate in landfills. Such models are essential to project contaminant concentrations in leachate, which can be used to assess the leachate contamination risk to groundwater. Moreover, since aging leads to a loss in acute toxicity to organisms, the ability to predict the extent of sequestration is of great importance in risk analysis.

To develop a more fundamental understanding of the bioavailability of HOCs sorbed to MSW, the research was designed to meet the following objectives: 
- Investigate the impacts of aging and sorbent decomposition on bioavailability.

- Compare rates of desorption and biodegradation; evaluate whether contaminant desorption limits bioavailability.

- Investigate the effect of individual lignocellulosic materials (cellulose, hemicellulose, and lignin) as well as their decomposition on toluene bioavailability. 


\section{Chapter 2}

\section{Literature Review}

This literature review is composed of four parts: characterization of MSW; bioavailability; factors controlling bioavailability; and aerobic degradation of toluene. The first part is a summary of municipal solid waste components. Considering the importance of organic matter in bioavailability, the individual components of organic matter (cellulose, hemicellulose, lignin etc.) in solid waste as well as their biodegradation and effect on sorption, humification are reviewed. In the following part, a brief definition of bioavailability and summary of published research involving bioavailability of organic compounds are provided. Literature on soils and sediments is emphasized because there is no published information on bioavailability in the landfill ecosystem. In the third part, mechanisms that cause reduced bioavailability are explained. Specifically, this part will focus on the factors controlling bioavailability such as aging and microorganisms. The following part includes information about aerobic toluene biodegradation; different biodegradation pathways and toluene oxidizing bacteria.

\subsection{Characterization of Municipal Solid Waste}

Municipal solid waste contains organic materials such as paper, food and yard waste and plastics. To be specific, MSW can be divided into six major chemical compound classes: non-cellulosic carbohydrates (hemicellulose, starch, and mono- and oligosaccharides), cellulose, proteins, lipids, lignin, and plastics (Pichler and Kögel-Knabner 2000). Paper and paperboard products make up the largest component of MSW. Of the total 229.9 millions of tons of MSW generated in the U.S. in 1999, 38.1\% were paper products. Although 41.9\% was recovered by recycling, there were still 50.8 million tons of paper that were deposited in landfills (US EPA 1999). Newsprint is produced from mechanical pulp with some chemical wood pulp. Only $7 \%$ of the raw materials are lost during the production of newsprint. Therefore, most compounds of the wood, lignin, cellulose, hemicellulose are present in newsprint. Office paper is made from a 
chemical pulp of high purity. Most of the lignin is removed during chemical treatment, leaving cellulose as the major component. The percentage of the cellulose varies depending on specific chemicals used (Calkin 1957). Food waste comprised 12.1\% of MSW; the major organic components of food waste are carbohydrate, protein and lipids (US EPA 1999).

\subsubsection{Cellulose and Hemicellulose}

Cellulose, a linear polymer made of glucose subunits linked by $\beta-1,4$ glycosidic bonds, is the most abundant biopolymer on earth (Senior 1990). Most native celluloses are composed of two different forms. The parallel oriented chains form highly ordered crystalline domains. The crystalline domain is interspersed by more disordered, amorphous regions. The native crystalline form of cellulose has a structure designated as type I, which can be converted into type II by alkali treatment. Depending on origin and pretreatment, the degree of crystallinity of cellulose can vary from $0 \%$ to $100 \%$ (Béguin and Aubert 1994). Evans et al. (1995) studied the crystallinity change during Kraft pulping process using X-ray diffraction, infrared (IR) spectroscopy and NMR spectroscopy. All three methods indicated that the degree of crystallinity of the cellulose increased as Kraft pulping proceeded due to preferential removal of the less ordered carbohydrates. Hunt et al. (2001) also reported cellulose fibril distortions were partially relaxed by the pulping process, which led to significant cellulose crystallinity increase.

Water decreases the glass transition temperature $\left(\mathrm{T}_{\mathrm{g}}\right)$ of dry cellulose from $225{ }^{\circ} \mathrm{C}$ to $-45{ }^{\circ} \mathrm{C}$ (Leboeuf et al. 2000). In aqueous solution, HOC sorption to cellulose should therefore be dominated by partitioning mechanism. Pure cellulose has a fairly low sorption capacity for organic compounds, with $1.0 \mathrm{mg} / \mathrm{g}$ for benzene and $1.4 \mathrm{mg} / \mathrm{g}$ for tetrachloride phenol (Rutherford et al. 1992). The low uptake of cellulose is determined by its high organic polarity $(\mathrm{O}+\mathrm{N}) / \mathrm{C}$ (Rutherford et al. 1992) and lack of aromaticity (Xing et al. 1994).

Cellulolytic microorganisms are found among diverse taxonomic groups. They usually occur in mixed populations comprising cellulolytic and non-cellulolytic species, which often interact synergistically (Béguin and Aubert 1994). Cellulose is highly insoluble in water. Cellulolytic 
microorganisms can hydrolyze the 1,4-glycosidic bonds of cellulose with cellulase, which can convert the complex cellulose to smaller cellobiose molecules (Pelczar Jr. and Reid 1958). Cellulases form a multicomponent enzyme system; with endoglucanases (EGs) that hydrolyse cellulose chains randomly, cellobiohydrolases $(\mathrm{CBHs})$ that hydrolyse cellobiose from the polymer ends and cellobiases that hydrolyse cellobiose to glucose (Cavaco-Paulo 1998). The individual component and their mode of action are summarized in Table 2.1 (Bhat and Bhat 1997). Amorphous cellulose is preferentially hydrolyzed while crystalline cellulose is more resistant to hydrolysis (Senior 1990). In both aerobic and anaerobic conditions, cellulose is substantially degraded by fungi and bacteria (Eleazer et al. 1997; Pichler and Kögel-Knabner 2000). In most natural environments, cellulose cannot be completely mineralized due to the protective effect of lignin, soil minerals and humus polymers. Cellulose can form chemical or physical linkages to these constituents to persist for a sufficient length of time to participate directly in humus formation (Bollag et al. 1998).

Enzymatic hydrolysis was used recently to investigate of the residual lignin and lignin-cellulose bonds in pulps. Karlsson et al. (2001) used cellulases and hemicelluases to study lignin-cellulose as well as lignin-hemicellulose bonds in Kraft pulps. It was found $40 \%$ of pine Kraft pulp was degraded by the cellulase treatment. The remaining cellulose was still of high molecular weight, which indicated a considerable portion of the residual lignin in the pine Kraft pulp was bonded to cellulose. The authors also reported the simultaneous removal of lignin and cellulose by the cellulase treatment. This result is similar to that of Hortling et al. (1990), who concluded that the $20-60 \%$ residual lignin dissolved during the enzymatic hydrolysis of pulps with a kappa number (most common parameter for determination of lignin content) below 58. 
TABLE 2.1 Components of Aerobic Fungal Cellulases

\begin{tabular}{|c|c|c|c|}
\hline Enzyme & Synonym & EC code & Mode of Action \\
\hline $\begin{array}{l}\text { endo-1,4- } \beta \text {-D- } \\
\text { glucanase }\end{array}$ & $\begin{array}{l}\text { 1,4- } \beta \text {-D-glucan } \\
\text { glucanohydrolase }\end{array}$ & EC 3.2.1.4 & $\begin{array}{c}\text {-G-G-G-G-G } \\
\uparrow \uparrow \uparrow \\
\text { Cleaves linkages at random } \\
\end{array}$ \\
\hline \multirow{2}{*}{$\begin{array}{l}\text { exo-1,4- } \beta \text {-D- } \\
\text { glucanase }\end{array}$} & \multirow{2}{*}{$\begin{array}{l}\text { 1,4- } \beta \text {-D-glucan } \\
\text { cellobiohydrolase }\end{array}$} & EC 3.2.1.91 & $\begin{array}{c}\text {-G-G-G-G-G- } \\
\uparrow \\
\text { Releases cellobiose either from reducing } \\
\text { or non-reducing end }\end{array}$ \\
\hline & & EC 3.2.1.74 & $\begin{array}{c}\text {-G-G-G-G-G- } \\
\uparrow \\
\text { Releases glucose from non-reducing end }\end{array}$ \\
\hline$\beta$-glucosidase & $\begin{array}{l}\text { cellobiose } \\
\beta \text {-D-glucoside } \\
\text { glucohydrolase }\end{array}$ & EC 3.2.1.21 & $\begin{array}{c}\text { G-G G-G G-G } \\
\uparrow \\
\uparrow \\
\text { Convert cellobiose to glucose }\end{array}$ \\
\hline
\end{tabular}

Hemicelluloses contain xylan, mannan, galactan and arabinan as the main heteropolymers (Dekker and Richards 1976). The principal monomers present in most hemicelluloses are Dxylose, D-mannose, D-galactose, and L-arabinose (Wenzl 1970). For native hemicelluloses, the most probable $\mathrm{T}_{\mathrm{g}}$ is around $180{ }^{\circ} \mathrm{C}$, and $30 \%$ moisture can lower the $\mathrm{T}_{\mathrm{g}}$ to room temperature (Back and Salmen 1982). Because of the much greater complexity of sugars and linkages in hemicelluloses, many more enzymes are involved in the complete hydrolysis of the backbone and the branches (Deobald and Crawford 2000). Because xylan is a common hemicellulose backbone constituent, much of the research on hemicellulases has focused on xylanases. The xylanolytic enzyme system is composed of $\beta$-1,4-endoxylanase, $\beta$-xylosidase, $\alpha$-Larabinofuranosidase, $\alpha$-glucuronidase, acetyl xylan esterase, and phenolic acid esterase. All these enzymes act cooperatively to convert xylan into its constituent sugars (Beg et al. 2001). Sugars produced can be readily detected colorimetrically (Sharrock 1988) using method proposed by Miller et al. (1960), Lever (1973), Mullings and Rarish (1984).

\subsubsection{Lignin}

Lignin is, after cellulose and hemicellulose, the third most abundant biopolymer on earth. It is present in the primary cell wall, which provides mechanical strength. The polymer is composed of aromatic alcohols, particularly three p-hydroxycinnamyl alcohols. Lignin plays an important 
role in humification processes. One of the widely accepted theories concerning organic matter humification in soil is that lignin and its degradation products such as phenols, quinones and more complex compounds are the main precursors in the formation of humic substances; their polymerization and condensation with $\mathrm{N}$-compounds such as protein, amino acids, nucleic acids is brought about by the soil microorganisms (Stevenson 1994; Sánchez-Monedero et al. 1999). Lignin is a glassy polymer with a glass transition temperature of $70{ }^{\circ} \mathrm{C}$ (LeBoeuf et al. 2000).

White-rot fungi are responsible for most of the lignin decomposition in nature and lignin degradation by white-rot fungi is faster than by any other organism (Tuomela et al. 2000). There are many genera of actinomycetes and eubacteria that can degrade extracted lignin and dehydrogenation polymer (synthetic lignin). Many bacterial strains, especially actinomycetes, can solubilize and modify the lignin structure extensively, but their ability to mineralize lignin is limited (Buswell and Odier 1987). Aerobic microorganisms are the primary lignin degraders in most environments. Anaerobic degradation of lignin is either not observed (Micales and Skog 1997; Pichler and Kögel-Knabner 2000; Odier and Monties 1983) or happens at very low speed under specified conditions. It was found that anaerobic rumen microorganisms are capable of degrading plant fiber cell wall (Kuhad et al. 1997). Colberg (1988) investigated the anaerobic microbial degradation of lignin compounds and concluded that the intermediate metabolic products called oligolignols may be partially degraded to $\mathrm{CO}_{2}$ and $\mathrm{CH}_{4}$ by anaerobic microorganisms. Benner and Hodson (1985) found elevated temperature of $55^{\circ} \mathrm{C}$ could enhance the anaerobic degradation of lignin.

\subsubsection{Poly (vinyl chloride) (PVC) and High Density Polyethylene (HDPE)}

PVC is composed of repeating vinyl chloride monomers $\left(-\mathrm{CH}_{2}-\mathrm{CH}-\mathrm{Cl}\right)$. In its unmodified form, $\mathrm{PVC}$ is a rigid polymer. Plasticizers are organic additives added to PVC compounds in order to improve their processing properties and make flexible products for a wide variety of purposes (Mersiowsky et al. 2001). PVC is a stable polymer in landfill environment. No biological or abiotic mechanisms for a depolymerisation process are known. Temperatures usually encountered in the landfill are in the range of $18-55^{\circ} \mathrm{C}$, which are substantially lower than 
temperatures required for thermal destruction (Mersiowsky et al. 2001).

Plasticizers are important in determining the glass transition temperature of PVC and consequently its sorptive behavior. Rigid PVC undergoes glass transition at temperatures between 60 and $80^{\circ} \mathrm{C}$, whereas for flexible PVC compounds this temperature range is reduced to around $0{ }^{\circ} \mathrm{C}$ at an average plasticizer content of approximately 30\% (Mersiowsky et al. 2001). Significant plasticizer loss can occur in landfill due to microbial transformation during the methanogenic landfill stage (Ejlertsson et al. 1997; Mersiowsky et al. 2001), which indicates that PVC containing plasticizers may be transformed from a rubbery to a glassy state in landfill environment.

Polyethylene consists of repeating ethylene $\left(\mathrm{CH}_{2}=\mathrm{CH}_{2}\right)$ monomers. The glass transition temperature of polyethylene is $-68{ }^{\circ} \mathrm{C}$ (Brandup et al. 1989). HDPE contains interstitial spaces between the polymer segments through which small molecules can diffuse.

\subsubsection{Protein and Lipid}

Proteins are one of the major constituents of living organisms. Proteins are made up of one or more polypeptide chains, each consisting of many $\alpha$-amino acid residues covalently linked by peptide bonds. The naturally occurring proteins are too large to enter the bacterial cell. The decomposition of protein occurs in two stages:

Enzymes
Protein $+\mathrm{H}_{2} \mathrm{O} \rightarrow$ polypeptides

Enzymes

Polypeptides $+\mathrm{H}_{2} \mathrm{O} \rightarrow$ mixture of individual amino acids

The amino acids taken into the cell may be used for the formation of proteins or subjected to further degradation to ammonia and $\mathrm{CO}_{2}$. Analysis of organic matter of municipal solid waste showed no significant change in protein content during aerobic and anaerobic treatment (Pichler and Kögel-Knabner 2000). One mechanism attributed to the persistence of protein or peptide is the microbial resynthesis of protein. Proteins may be preserved by encapsulation into refractory 
cell wall polymer of microorganisms, e.g., lipids, and become poorly degradable (Dinel et al. 1996; Lichtfouse et al.1996) and may be incorporated into humic substances (Sánchez-Monedero et al. 1999).

Lipids include a variety of fat-like substances. Many bacteria are capable of decomposing fats through lipases. Lipases cause a hydrolytic breakdown through addition of water; the lipid molecule is split into glycerol and its respective fatty acid. González-Vila et al. (1995) studied the progressive transformation of lipids in landfills. Samples were taken from different depths in the landfill. The depth of the samples represented the disposal time. The amount of Sohxletextractable lipids showed irregular behaviors with depth, which might be due to the great heterogeneity of the samples and microbial resynthesis. Microbially synthesized long-chain lipids are resistant to attack by microorganisms (Dinel et al. 1996).

\subsection{Bioavailability}

Bioavailability represents the accessibility of a chemical for bioaccumulation, where bioaccumulation is the accumulation of a contaminant via all routes available to the organism (Alexander 2000). Sorption processes have been shown to influence the bioavailability of various organic chemicals. As a result of sorption both increases and decreases in biodegradation rate are possible. Sorption often has been found to stimulate biodegradation when the compound to be degraded or its metabolites are toxic to the microorganisms. In this case sorption reduces the toxic chemical concentration. Ehrhardt and Rehm (1985) found cells of Pseudomonas and Candida can not degrade phenol at concentration higher than $1.5 \mathrm{~g} / \mathrm{L}$. The presence of activated carbon enhanced the biodegradation by quickly reducing the toxic phenol concentration and set low quantities of adsorbed phenol free for gradual biodegradation. More often, sorption has been reported to decrease bioavailability (White et al. 1999; Steinberg, et al. 1987; Hatzinger and Alexander 1997), although there are inconsistencies regarding the ability of microorganism to degrade sorbed pollutants (Tang et al. 1998, Laor et al. 1996). Most studies support the concept that contaminants that partitioned into natural organic matter (Calvillo and Alexander 1996; Chung et al. 1993; Crocker et al. 1995; Harms and Zehnder 1995) or diffused into micropores 
(Nam and Alexander 1998; Hatzinger and Alexander 1997, Löser et al. 1999) are not directly available for degradation. Technologies such as addition of nutrients, electron acceptor and bacteria are unlikely to stimulate the degradation of pollutants that are sequestered (Hatzinger and Alexander 1997). Only when organic compounds desorb out of sorbents to a site where they are freely available to microorganisms can they be degraded. Desorption of organic compounds out of organic matter can be very slow due to the mechanisms described below. In most cases, the lower desorption rate limits degradation rate and bioavailability is limited by desorption.

\subsection{Factors Controlling Bioavailability}

\subsubsection{Aging Effect}

Sorption and consequently the loss of bioavailability is a time-dependent process. Numerous studies showed contaminant bioavailability to microorganisms decreases with time up to a time beyond which a further decline is no longer detectable (Table 2.2). Sorption has been observed to occur in two stages: a rapid step involving association with labile domains near the particle surface, followed by a slower step (Pignatello and Xing 1996; Johnson et al. 1999; Brusseau et al. 1991). Karickhoff (1984) showed that sediments continue to sorb hydrophobic compounds from water indefinitely at a slow rate after the initial rapid uptake. Continued slow sorption can be attributed to HOCs diffusing into remote micropores or hard/condensed organic matter (Alexander 2000). During aging, more molecules move into sites from which desorption is retarded; this process is responsible for the reduced bioavailability as aging time increases. In the following section, the mechanisms behind the aging phenomenon are explained.

TABLE 2.2 Compounds Shown to Become Less Bioavailable as a Result of Aging

\begin{tabular}{ccccc}
\hline Compounds & Sorbent & $\begin{array}{c}\text { Aging } \\
\text { period }\end{array}$ & $\begin{array}{c}\text { \% Non- } \\
\text { bioavailable }\end{array}$ & Reference \\
\hline 4-nitrophenol & Soil (lima loam) & $103 \mathrm{~d}$ & 20.5 & Hatzinger and Alexander 1997 \\
Naphthalene & Soil & 3 years & 25 & Guerin and Boyd 1997 \\
Phenanthrene & Soil & $103 \mathrm{~d}$ & 31 & White et al. 1999 \\
Phenanthrene & NaOH extracted soil & $103 \mathrm{~d}$ & 29.5 & White et al. 1999 \\
\hline
\end{tabular}




\section{Sorption to Hard/Glassy Organic Carbon}

Organic matter consists of humic substances and partially decomposed biomass. When present above trace levels, organic matter is the predominant sorbent of hydrophobic organic compounds (Xing and Pignatello 1997). The OM is viewed as a tangle of macromolecules that offers an organo-lipophilic phase. Evidence supporting sorption by OM was provided by Dec (1997), who used ${ }^{13} \mathrm{NMR}$ to study residues of fungicide cyprodinil. The analysis of fulvic acid and humin revealed they contained mainly unmodified cyprodinil molecules, which was apparently sequestered in soil by physical forces other than covalent binding.

Organic matter among different soils or within the same soil differ in polarity, elemental composition, aromaticity, condensation and degree of diagenetic evolution (Weber et al. 1992; McGinley et al. 1993; Young and Weber 1995). Therefore, observations of sorptive behavior vary. Organic matter is further modeled as a combination of rubbery (soft carbon) and glassy (hard carbon) polymers (Pignatello and Xing 1996; Weber and Huang 1996). The rubbery (soft carbon) phase is oxidized, amorphous, expanded, soft, loosely knit organic matter domain with flexible, swollen pores (Huang and Weber 1997). Such highly amorphous organic matter domains act as liquid-like partitioning phases for hydrophobic solutes. Consequently isotherms are linear and no hysteresis is observed. HOC sorption to and desorption from the rubbery (soft carbon) phase is faster than for the glassy (hard carbon) phase. The glassy phase is composed of condensed, relatively reduced, less polar, hard organic matter with relatively well-defined, rigid mesopores and micropores (Xing and Pignatello 1997). Under aqueous conditions, water molecules are unlikely to penetrate and expand such hydrophobic matrices (Huang and Weber 1997). Sorption of hydrophobic molecules into glassy phases can be explained by dual model sorption (Xing and Pignatello 1996). Dual-mode sorption is the sum of normal linear partitioning taking place in the bulk of the polymer and a hole-filling mechanism in which the incoming molecules undergo Langmuir-like adsorption in voids internal to the polymer matrix. Glassy OM can be converted to rubbery OM by increasing the temperature above glass transition point or by softening it by organic solvent. Diffusion into organic matter is often termed as sequestration. Unlike bound compounds, those that are sequestered can be recovered from soil by exhaustive extraction with organic solvents, but their bioavailability and toxicity gradually diminish as a 
result of aging (Dec et al. 1997).

Sorption into glassy/hard organic matter is a possible rate limiting step in desorption because (1) the pressures associated with sorption are significantly greater than those involved in desorption. Hydrophobic solute molecules may hysteretically adsorb or condense within such pores; (2) diffusion in or out of tightly cross-linked and condensed OM is usually more highly activated and can be very slow.

Weber and Huang (1996) studied the change of phase distribution relationships with time under nonequilibrium conditions. They found sequence of accessibility of pollutant to each component and the associated dominant mechanism in soil is time dependent. Soft or rubbery organic matter is readily accessed by HOC molecules and associated sorption rates are relatively fast. The mechanism of sorption to this domain is one of partitioning. Once the readily accessible domain site reaches apparent equilibrium, the condensed organic matter domain is accessed and the overall sorption process is dominated by the behavior of this domain. Aged samples, for which sorbent-sorbate contact time may be months or years, can be enriched in the slow fraction owing to the slow diffusion into condensed organic matter.

\section{Diffusion through Hydrophobic Micropores}

Another mechanism proposed to explain the slow desorption and sequestration is retarded diffusion through and along micropores (Steinberg et al. 1987; Brusseau et al. 1991) and micropore geometries giving rise to different mechanisms of desorption (Werth and Reinhard 1997). To differentiate the retarded diffusion through organic matter and micropores, Cornellissen et al. (1998) tested desorption from model sorbents without organic matter and sediment whose organic matter had been completely removed. Significant slow and very slow desorption fractions were observed for these materials. This result indicated that the presence of pores with hydrophobic walls resulted in strong desorption retardation. Similar results were reported by Farrell et al. (1999), who studied the desorption rates of chloroform, TCE, and PCE from silica gel and concluded pores less than $2 \mathrm{~nm}$ in diameter were responsible for slow desorption. 
There is inconsistency in the pore classification between IUPAC (International Union of Pure and Applied Chemistry) and SSSA (Soil Science Society of American). Table 2.3 summarizes the classification used by IUPAC (1972) and SSSA (1997), and IUPAC definition will be used throughout this research. Release of contaminants sorbed in micropores may be hindered by high adsorption energies. Micropore desorption has been reported to be an activated process. Everett and Powl (1976) calculated the adsorption energy might be up to a factor of 3.5 times greater than in micropores compared to that on an open surface. Higher adsorption energies lead to reduced diffusive transport rates (Farrell and Reinhard 1994a). Besides increased adsorption, micropores also represent potential sites for steric entrapment of sorbing molecules. The molecules might be effectively trapped and only become bioavailable through desorption and subsequent diffusion through a tortuous pathway. Movement through that tortuous path would be exceedingly slow because of the steric hindrance, reduced advection of water and turtuosity of pore network. As the pore size decreases, the ratio of pore surface area to pore volume increases. The result is that a given sorbate molecule spends relatively more time adsorbed on the surface than in solution for smaller pores compared to larger pores. Transport rates are reduced because the relative slowness of surface diffusion compared to aqueous diffusion (de Boer 1968). Nam and Alexander (1998) conducted bioavailability test on model solids: glass beads without pores, silica beads with nanopores, polystyrene beads with hydrophobic surfaces but no pores, diatomite beads with comparatively large pores, and polystyrene beads with hydrophobic surfaces and nanopores. The result showed neither hydrophobicity nor surface area alone rendered phenanthrene unavailable to bacteria. However, bioavailability of a hydrophobic compound such as phenanthrene can be markedly reduced by particles bearing nanopores having hydrophobic surfaces. In contrast, nanopores with hydrophilic surfaces or particles without nanopores did not reduce bioavailability. 
TABLE 2.3 Classification of Pore Size

\begin{tabular}{cccc}
\hline & Macropores & Mesopores & Micropores \\
\hline IUPAC (1972) & $>50 \mathrm{~nm}$ & $2-50 \mathrm{~nm}$ & $<2 \mathrm{~nm}$ \\
SSSA (1997) & $>75 \mu \mathrm{m}$ & $30-75 \mu \mathrm{m}$ & $5-30 \mu \mathrm{m}$ \\
\hline
\end{tabular}

\section{Humification}

The classical theory suggests that humic substances are formed through modification of lignin. Another theory in agreement with this suggests that humic acids are derived from quinones, which in turn are formed from polyphenols or lignin decomposition products (Stevenson 1994). Humification is composed of two stages: The first stage involves degradative processes that lead to the formation of substrates. The more recalcitrant lignin components are selectively preserved. In the second stage, the substrates and the preservation products are further transformed by synthetic processes, which result in the formation of humus. Oxidative coupling plays an important role in humus formation. The reaction can be catalyzed by either enzymes originating from microorganisms or abiotic catalysts such as clay minerals or metal oxides.

Humus is a substance that can be envisioned as a large polymer with aromatic and aliphatic moieties. Humic substances do not have a definitive structure; instead, they exhibit an open structure in a state of constant formation or modification. For this reason, any substance that chemically resembles a natural humus constituent can participate in humification and become incorporated into soil organic matter (Bollag et al. 1998). Organic compounds can be sequestered (Dec et al. 1997), adsorbed (Dec and Bollag 1997) or covalently bonded to humus (Park et al. 2000). Only if compounds or their metabolites are bound through covalent linkages are they considered to be an integral part of humus (Achtnich et al. 1999). Compounds that are bound chemically are considered irreversiblely bound because they cannot be recovered by methods that do not change the chemical character of the immobilized compounds (Dec et al. 1997). They are highly resistant to exhaustive extraction with organic solvents and release by microbial activity (Dec and Bollag 1988).

Several mechanisms are involved in the incorporation of organic compounds into humus. The 
incorporation relies largely on the oxidative coupling reaction. In oxidative coupling reactions, aromatic compounds are oxidized to form free radicals or quinones. The unstable oxidation products are then subject to chemical coupling (Park et al. 1999). The chemical coupling not only happens among reactive free radicals, they also couple to molecules of relatively resistant compound (Roper et al. 1995). If the reaction takes place in polluted soils, they couple mainly to humus, which abounds in stable free radicals (Stevenson 1994), resulting in the formation of covalent linkage between humic substances and the xenobiotics or their degradation products (Bollag et al. 1992). Humus itself also exhibits catalytic properties due to the presence of free radical components (Stevenson 1994).

Sarkar et al. (1988) provided evidence that oxidative coupling is mediated by enzymes. In this study, ${ }^{14} \mathrm{C}$-labeled 2,4-dichlorophenol, natural fulvic acid and four oxidoreductive enzymes were incubated. It was found that no binding was observed in control samples with boiled enzyme. In samples with non-boiled enzymes, however, substantial amounts of radioactivity were incorporated into fulvic acid. Due to the complexity of soil organic matter, model systems have been used for determining the types of chemical bonds and reaction mechanism involved. Typically a free enzyme is incubated with a single xenobiotic substrate in the presence of a humus constituent as co-substrate. Kim et al. (1998) studied reaction of herbicide bentazon and its metabolites with humic monomers in the presence of oxidoreductases. Transformation was monitored on the basis of disappearance of bentazon/metabolites from supernatant. It was found that the extent of transformation depended upon the chemical structure of the substrate, the type and concentration of co-substrate, and the $\mathrm{pH}$ of the reaction mixture. The difference in the reactivity of various substrates appears to be related to the coupling potential of the side groups. The hydroxyl group of hydroxy-bentazon is more reactive than a side chain such as a methyl group. Therefore, after incubation of $24 \mathrm{~h}, 100 \%$ of 6-hydroxy-bentazon was transformed in the presence of laccase and guaiacol at $\mathrm{pH} 3.0$ while the transformation was $20 \%$ for des-isopropylbentazon under the same condition.

Park et al. (1999) revealed that the effect of humic constituents on the transformation of chlorinated phenols and anilines was determined by different transformation mechanisms. When 
4-CP and catechol were incubated together with laccase, the former was oxidized with the formation of free radicals, while the latter formed phenoxide anions and o-quinones. Catechol was transformed at a higher rate than 4-CP. Because the oxidation products of 4-CP and catechol differed in their oxidized forms and the rate of formation, only $21.4 \%$ of 4-CP was transformed. On the contrary, when both 4-CP and syringaldehyde were oxidized to free radicals, $82 \%$ of 4 $\mathrm{CP}$ was transformed because 4-CP and syringaldehyde were on the same oxidized form and capable of efficient cross coupling.

To further approximate the conditions in soil, Park et al. (2000) studied chlorinated phenol transformation in the presence of humic acid. In this study, humic acid in many cases enhanced the incorporation of chlorinated pollutants into OM. The author explained the result by speculating that the chlorinated compounds were subject exclusively to oligomerization in the absence of humic acid. When humic acid was present, it underwent binding. However, the effect of humic acid also depended on the substrate and the type of catalyst. It was found that the transformation of 4-CA was only slightly affected by humic acid. This was due to the large oligomerization/low binding to humic acid.

Covalent binding can be achieved through other reactions. Dec et al. (1997a) investigated the soil bound residues of ${ }^{13} \mathrm{C}$ labeled fungicide cyprodinil by NMR spectroscopy. Soil bound residue was prepared by incubating $500 \mathrm{mg} / \mathrm{kg}$ of 2-pyrimidyl- ${ }^{13} \mathrm{C}$-and ${ }^{14} \mathrm{C}$-labeled cyprodinil and soil. Control samples were amended with acetone and no cyprodinil was added. After $169 \mathrm{~d}$ incubation, soil samples were extracted to separate humic acid. Comparing the ${ }^{13} \mathrm{C}-\mathrm{NMR}$ spectra for the humic acid extracted from soil after incubation with those extracted from soil without incubation, it was concluded that the cyprodinil molecule was cleaved between the aromatic rings. Phenyl and pyrimidyl moieties resulting from the cleavage were covalently bound to humic acid and became an integral part of humus. To identify whether the ${ }^{13} \mathrm{C}$-labeled fragments were bound covalently or only entrapped in the molecular net of humic acid, Dec et al. (1997b) used a silylation procedure to characterize bound and sequestered residues of cyprodinil in soil. Silylation reaction involved the substitution of a silyl moiety for the hydrogen atom in various functional groups without further alteration of the derivatized molecule. Since replacement of the 
active hydrogens in the soil matrix with silyl groups caused a disintegration of humic aggregates into smaller fragments, silylated humic materials were soluble in organic solvent and was suitable for high resolution in NMR. It was demonstrated that the phenyl and pyrimidyl moieties of the cleaved fungicide became integral parts of the humic acid matrix.

Thron et al. (1996) used ${ }^{15} \mathrm{~N}-\mathrm{NMR}$ spectroscopy to demonstrate covalent binding of ${ }^{15} \mathrm{~N}$-labeled aniline to humic acid when the two components were dissolved in water and stirred for 5 days at $\mathrm{pH}$ 6. The changes in the chemical shifts of the ${ }^{15} \mathrm{~N}$ atom indicated that binding was due to nucleophilic addition reactions of aniline with the quinone or carbonyl groups typical for humic substances.

Ionic bond between organic compounds and humic substances is another mechanism involved in irreversible binding process. Senesi and Testini (1980) reported the formation of ionic bonds between protonated s-triazine and carboxylate anion.

\subsubsection{Difference among Organisms}

Whether or not sorbed contaminants can be directly available to microorganisms is still in debate. The most commonly accepted concept is that desorption is a prerequisite of biodegradation, i.e., the contaminants need to diffuse out of the sorbent first before they can be degraded by microorganisms. Recently, other researchers showed evidence that sorbed substrate may be directly available for degradation by attached cells (Feng et al. 2000; Park et al. 2001; Guerin and Boyd 1992; Calvillo and Alexander 1996; Tang et al. 1998; Grosser et al. 2000; Laor et al. 1996) All of the conclusions of degradation of sorbed compounds are based on the evidence that the biodegradation rate is higher than that calculated from instantaneous desorption (Feng et al. 2000) or part of sorbed compounds that can not be removed by abiotic desorption was bioavailable to bacteria (Park et al. 2000; Calvillo and Alexander 1996). Although no evidence of direct consumption of sorbed contaminant is provided, this evidence showed significant diversity among microorganisms in the abilities to degrade contaminants. These important biological traits in evaluating bioavailability include the ability to attach to the sorbent 
surface and to survive on low substrate concentration (Scow and Johnson 1997).

\section{Kinetic Parameters}

Guerin and Boyd (1992) studied the ability of two bacterial species to degrade naphthalene. Pseudomonas putida 17484 (Pp17484) and NP-Alk were used to study biodegradation of naphthalene in the presence of soil. For NP-Alk, decreases in the rate and extent of naphthalene mineralization were observed with increases in the amount of added soil. Sorbed naphthalene was not utilized by the cells. In contrast, Pp17484 showed a rapid exponential phase followed by a linear phase of ${ }^{14} \mathrm{CO}_{2}$ production. A portion of sorbed naphthalene was also available to the organisms. In a later paper (Guerin and Boyd 1995), the authors found Pp17484 maintained naphthalene degradation ability at low levels for long periods of time in the absence of naphthalene and could rapidly respond to new additions of naphthalene to culture. In contrast, the NP-Alk was unable to maintain naphthalene degradation activity in the long-term absence of naphthalene and needed many hours after exposure to naphthalene before degradation activity was induced. Gueer and Shelton (1992) examined two Alcaligene sp strains with similar maximum growth rates but with 10 fold difference in the half-saturation constant $\mathrm{K}_{\mathrm{s}}$. When concentration of 2, 4-D was high $(60$ and $600 \mu \mathrm{g} / \mathrm{ml})$, the strain with the lower $\mathrm{K}_{\mathrm{s}}$, could use 2, 4-D more rapidly than the strain with the higher $\mathrm{K}_{\mathrm{s}}$. It is speculated that the half-saturation constant influences the strain's degradation ability in a substrate-limited environment.

Feng et al. (2000) investigated the bioavailability of soil-sorbed biphenyl to Pseudomonas putida P106 and Rhodococcus Erythropolis NY05. Although strain NY05 had a much lower $\mathrm{K}_{\mathrm{s}}$ value than P106, the possession of low $\mathrm{K}_{\mathrm{s}}$ did not give NY05 the competitive advantage for sorbed biphenyl. To explain the difference between two strains, the author proposed the substrate acquisition mechanism. The hydrophobic molecule sorbed on the surface may dissolve in the lipids at the bacteria surface before entering the cytoplasm. The gram-positive bacterium NY05 has $90 \%$ of peptidoglycan. The gram-negative bacterium P106 has an additional lipopolysaccharide layer besides the peptidoglycan, which contributed to the dissolution of HOCs to lipids at the bacteria surface. 


\section{Attachment}

The attachment of bacteria to sorbents likely influences their biodegradation ability. Although there appears to be a qualitative consensus that surfaces influence bacterial metabolism, the experimental observations are not always consistent; neither has a general explanation been advanced for this influence. Even for the same experimental result, researchers are arguing the different mechanisms behind the phenomena. A positive influence of surfaces on bacterial activity was found when marine bacteria were used to degrade amino acid (Bright and Fletcher 1983). The author attributed it to the accumulation of substrate at the surface of sediments.

Calvillo and Alexander (1996) compared the biodegradation of cells with different ability to attach to sorbents. Cells, which can attach to the surfaces of sorbent, showed high mineralization extent after $150 \mathrm{hrs}$. It was speculated this difference of utilization might involve lipids at the bacterial surface, the hydrophobic molecules on the solids dissolved first into these lipids before entering the liquid phase. It was also found that $80 \%$ of $120 \mu \mathrm{g}$ of biphenyl sorbed to the beads were mineralized by consortium SBP-1. But none of the twelve bacteria isolated from the consortium could mineralize sorbed biphenyl. The mechanisms involved in this phenomenon were not fully determined in this investigation. Harms and Zehnder (1994) used porous Teflon beads to study the degradation of sorbed 3-chlorodibenzofuran by a Sphingomonas sp. and found that attached cells degraded the bound chemical more rapidly than could be accounted for by the rates of desorption into the aqueous phase.

\section{Enrichment Techniques}

Tang et al. (1998) used different enrichment techniques to isolate phenanthrene-degrading bacteria. Bacterium P5-2 and consortium NL-W were grown on phenanthrene sorbed to biobeads. It was shown sorbed phenanthrene was degraded faster and to a greater extent by P5-2 and NL-W than bacteria P3 and RB-P, which were isolated on nonsorbed substrate. Possible mechanisms involved were production of surfactants or direct utilization of sorbed chemicals by attaching to the solids. Grosser et al. (2000) selected bacteria in the presence of a sorptive phase. When selected strain SM7.6.1 was incubated in the presence of sorptive phase, it was found that the mineralization extent of SM7.6.1 was higher than other bacteria that were not enriched under 
the same condition (C4.7, S2.1). The author explained this difference by suggesting the strain SM7.6.1 was better adapted to sorptive environments than other isolates.

\subsection{Aerobic Toluene Degradation}

The oxidation of toluene can be initiated by insertion of $\mathrm{O}$ into any of the four unique $\mathrm{C}-\mathrm{H}$ bonds in this molecule (Fig. 2.1). Toluene 4-monooxygenase (T4MO) catalyzes reaction from toluene to $p$-cresol (4-hydroxytoluene). Similarly, Toluene 3-monooxygenase (T3MO) produces $m$ cresol (3-hydroxytoluene) and Toluene 2-monooxygenase (T2MO) produces $o$-cresol (2hydroxytoluene). Xylene monooxygenase (XMO, also toluene side chain monooxygenase) hydroxylates the methyl carbon to form benzyl alcohol. In addition, toluene dioxygenase (TDO) can insert both atoms of oxygen into toluene to form cis-dihydrodiol (Arp et al. 2001).

Bacteria have diverse metabolic capabilities to degrade toluene. Different toluene oxidizers and their kinetic parameters are summarized in Table 2.4. Pseudomonas putida F1 (PpF1 ATCC: 700007) was selected in this study because of it has been subjected to extensive study (Gibson et al. 1968a; 1968b; 1970; 1989) and it has fast toluene biodegradation rate. The bacterium pseudomonas putida 39D was isolated from soil by selective culture with ethylbenzene as the carbon source (Gibson et al. 1968a). Its ability to degrade toluene, benzene, isopropylbenzene was also detected. Its degradation pathway (TDO pathway) was first demonstrated by Gibson et al. (1970), as shown in Fig. 2.1. This strain was later designated P. putida F1 (Gibson et al. 1989). According to Stanier et al. (1966), PpFl is unicellular rod, gram negative. They are motile by means of one or more polar flagella and do not form spores, stalks or sheaths. The enzyme involved in toluene degradation is TDO, a multicomponent dioxygenase composed of three separable protein components (Zylstra and Gibson 1989). TDO is a versatile enzyme with a relaxed specificity, which allows the organism to use a wide range of aromatic compounds such as benzene, ethylbenzene, phenol, and benzyl alcohol as carbon source (Gibson and Parales 2000; Gibson et al. 1968a). 
TABLE 2.4 Model Parameter for Aerobic Toluene Biodegradation by Pure Cultures

\begin{tabular}{|c|c|c|c|c|c|c|c|}
\hline Bacteria & $\begin{array}{c}\mathrm{T} \\
\left({ }^{\circ} \mathrm{C}\right)\end{array}$ & $\begin{array}{c}\max . \text { conc. }^{\mathrm{b}} \\
(\mathrm{mg} / \mathrm{L})\end{array}$ & $\begin{array}{l}\mu_{\max } \\
\left(\mathrm{h}^{-1}\right)\end{array}$ & $\begin{array}{c}\mathrm{K}_{\mathrm{s}} \\
(\mathrm{mg} / \mathrm{L})\end{array}$ & $\begin{array}{c}\mathrm{K}_{\mathrm{i}}{ }^{\mathrm{d}} \\
(\mathrm{mg} / \mathrm{L}) \\
\end{array}$ & $\begin{array}{l}Y_{X / S}{ }^{e} \\
(g / g)\end{array}$ & Reference \\
\hline$P . p F 1$ & 30 & 43 & $0.86 \pm 0.01$ & $13.8 \pm 0.9$ & 1 & $1.28 \pm 0.13$ & Reardon et al. 2000 \\
\hline P. $p R 1^{a}$ & 25 & 4 & 0.504 & 0.1 & / & 1.2 & Pedersen et al. 1997 \\
\hline P.p. $54 G$ & 24 & 50 & $0.42 \pm 0.05$ & $3.98 \pm 0.78$ & $42.78 \pm 3.87$ & $0.90 \pm 0.13$ & Mirpuri et al. 1997 \\
\hline P.p.O1 & 30 & 70 & 0.72 & 15.07 & 44.33 & 0.64 & Oh et al. 1994 \\
\hline P. fragi $B 1$ & room & 10 & $0.543 \pm 0.076$ & $1.96 \pm 0.91$ & l & $1.22 \pm 0.1$ & Chang et al. 1993 \\
\hline P. sp. X1 & room & 10 & $0.452 \pm 0.115$ & $1.88 \pm 1.26$ & / & $0.99 \pm 0.25$ & Chang et al. 1993 \\
\hline P.p. 23973 & 32 & 30 & 0.437 & 6.0 & 1980 & 1 & Chio et al. 1992 \\
\hline P. p mt-2 & $/^{\mathrm{c}}$ & 1 & 1 & $0.708 \pm 0.156$ & / & I & Duetz et al. 1998 \\
\hline B. серасіа $G 4$ & / & / & / & 2.35 & / & / & Arp et al. 2001 \\
\hline
\end{tabular}

${ }^{a}$ A value of $0.048 \mathrm{~h}^{-1}$ for the specific decay rate was also reported. ${ }^{\mathrm{b}}$ Maximum toluene concentration. ${ }^{\mathrm{c}}$ Not available. ${ }^{\mathrm{d}}$ Parameters are for the Monod model unless a value of $\mathrm{K}_{\mathrm{i}}$ is given, in which case the Andrews model was used. ${ }^{\mathrm{e}}$ The theoretical value of $\mathrm{Y}_{\mathrm{X} / \mathrm{S}}$ for growth on toluene is $1.23 \mathrm{~g} / \mathrm{g}$.

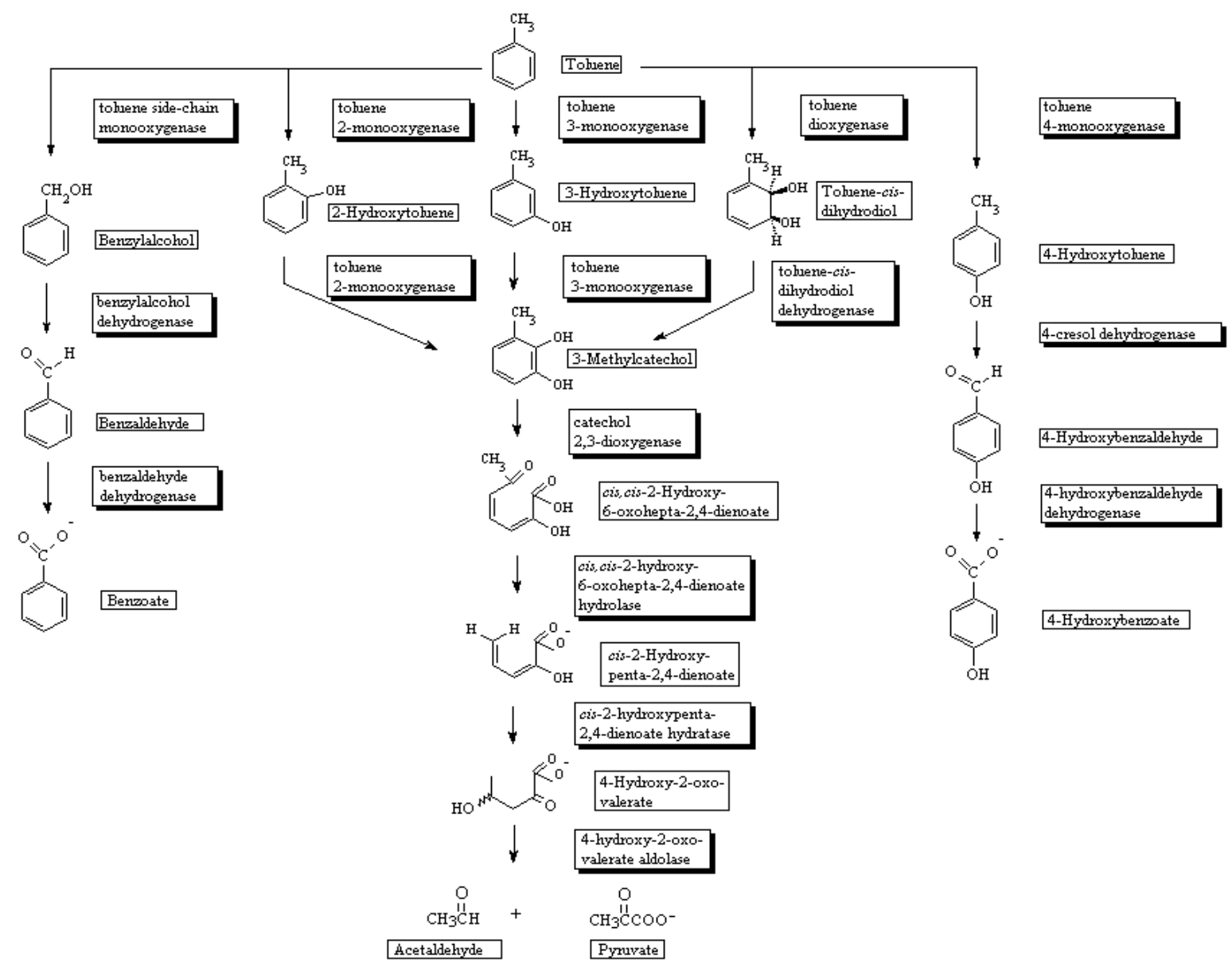

FIGURE 2.1 Toluene pathway map.

source: $\underline{\text { http://umbbd.ahc.umn.edu/tol/tol_map.html }}$ 


\section{Literature Cited}

Achtnich, C.; Fernandes, E.; Bollag, J. M.; Knackmuss, H. J.; Lenke, H. Covalent binding of reduced metabolites of $\left({ }^{15} \mathrm{~N}_{3}\right)$ TNT to soil organic matter during a bioremediation process analyzed by ${ }^{15} \mathrm{~N}$ NMR spectroscopy. Environ. Sci. Technol. 1999, 33, 4448-4456.

Alexander, M. Aging, bioavailability, and overestimation of risk from environmental pollutants. Environ. Sci. Technol. 2000, 34, 4259-4265.

Aminabhavi, T. M.; Naik, H. G. Sorption/desorption, diffusion, permeation and swelling of high density polyethylene geomembrane in the presence of hazardous organic liquids. J. Hazardous Materials. 1999, 64, 251262.

Arp, D. J.; Yeager, C. M.; Hyman, M. R. Molecular and cellular fundamentals of aerobic cometabolism of trichloroethylene. Biodegradation. 2001, 12, 81-103.

Back, E. L.; Salmen, N. L. Glass transitions of wood components hold implications for molding and pulping processes. Tappi. 1982, 65, 107-110.

Beg, Q. K.; Kapoor, M.; Mahajan, L.; Hoondal, G. S. Microbial xylanases and their industrial applications: a review. Appl. Microbiol. Biotechnol. 2001, 56, 326-338.

Béguin, P.; Aubert, J-P. The biological degradation of cellulose. FEMS Microbiol. Rev. 1994, 13, 25-58.

Bhat, M. K.; Bhat, S. Cellulose degrading enzymes and their potential industrial applications. Biotechnol. Adv. 1997, 15, 583-620.

Bollag, J. M.; Myers, C. J.; Minard, R. D. Biological and chemical interactions of pesticides with soil organic matter. Sci. Total. Environ. 1992, 123/124, 205-217.

Bollag, J. M.; Dec, J.; Huang, P. M. Formation mechanisms of complex organic structures in soil habitats. Adv. Agron. 1998, 63, 237-266.

Brandup, J.; Immergnt, E. H.; Grulke, E. A. Polymer Handbook, Wiley, New York. 1989, p206.

Brenner, R.; Hodson, R. E. Thermophilic anaerobic biodegradation of $\left({ }^{14} \mathrm{C}\right)$ lignin, $\left({ }^{14} \mathrm{C}\right)$ cellulose and $\left({ }^{14} \mathrm{C}\right)$ lignocellulose preparations. Appl. Environ. Microbio. 1985, 50, 971-976.

Bright, J. J.; Fletcher, M. Amino-acid assimilation and respiration by attached and free-living populations of a marine Pseudomonas-sp. Microbiol. Ecol. 1983, 9, 215-226.

Brusseau, M. L.; Jessup, R. E.; Rao, S. C. Nonequilibrium sorption of organic chemicals: elucidation of rate-limiting processes. Environ. Sci. Technol. 1991, 25, 134-142. 
Buswell, J. A.; Odier, E. Lignin biodegradation. CRC Crit. Rev. Biotechnol. 1987, 6, 1-60.

Calkin, J. B. Paper making materials and processes. In Modern pulp and paper making. Reinhold Publishing Corporation. New York. 1957, p 53-55.

Calvillo, Y. M.; Alexander, M. Mechanism of microbial utilization of biphenyl sorbed to polyacrylic beads. Appl. Microbio. Biotechnol. 1996, 45, 383-390.

Cavaco-Paulo, A. Mechanism of cellulase action in textile processes. Carbohyd. polym. 1998, 37, 273-277.

Christenssen, T. H.; Kjesdsen, P.; Albrechsen, H. J.; Heron, G.; Nielsen, P. H.; Bjerg, P. L.; Holm, P. E. Attenuation of landfill leachate pollutants in aquifers. Crit. Rev. Environ. Sci. Technol. 1994, 24, 119-202.

Chung, G. Y.; McCoy, B. J.; Scow, K. M. Criteria to assess when biodegradation is kinetically limited by intraparticle diffusion and sorption. Biotechnol. Bioeng. 1993, 41, 625-632.

Colberg, P. J. Anaerobic microbial degradation of cellulose, lignin, oligolignols, and monoaromatic lignin derivates. In Biology of Anaerobic Microorganisms. Zehnder, A. J. B. (ed). Wiley, USA. 1988, p 333-372.

Connaughton, D. F.; Stedinger, J. R.; Lion, L. W.; Schuler, M. L. Description of time-varying desorption kinetics: release of naphthalene from contaminated soils. Environ. Sci. Technol. 1993, 27, 2397-2403.

Cornelissen, G.; van Noort, P. C. M.; Govers, H. A. J. Mechanism of slow desorption of organic compounds from sediments: a study using model sorbents. Environ. Sci. Technol. 1998, 32, 3124-3131.

Cozzarelli, J. M.; Eganhouse, R. P.; Baekecker, M. J. Transformation of monoaromatic hydrocarbons to organic acids in anoxic groundwater environment. Environ. Geol. Water Sci. 1990, 16, 135-141.

Cozzarelli, J. M.; Suflita, J. M.; Ulrich, G. A.; Harris, S. H.; Scholl, M. A.; Schlottmann, J. L.; Christenson, S. Geochemical and microbiological methods for evaluating anaerobic processes in an aquifer contaminated by landfill leachate. Environ. Sci. Technol. 2000, 34, 4025-4033.

Crocker, F. H.; Guerin, W. F.; Boyd, S. A. Bioavailability of naphbthalene sorbed to cationic surfactant-modified smectite clay. Environ. Sci. Technol. 1995, 29, 2953-2958.

de Boer, J. H. The Dynamical Character of Adsorption. Clarendon Press, Oxford. 1968.

Dec, J.; Haider, K.; Benesi, A.; Rangaswamy, V.; Schäffer, A.; Plücken, U.; Bollag, J. M. Analysis of soil-bound residues of ${ }^{13} \mathrm{C}$-labeled fungicide cyprodinil by NMR-spectroscopy. Environ. Sci. Technol. 1997a, 31, 1128-1135.

Dec, J.; Haider, K.; Schäffer, A.; Fernandes, E.; Bollag, J. M. Use of a silylation procedure and ${ }^{13} \mathrm{C}-\mathrm{NMR}$ spectroscopy to characterize bound and sequestered residues of cyprodinil in soil. Environ. Sci. Technol. 1997b, 31, 2991-2997.

Dec, J.; Bollag, J. M. Determination of covalent and noncovalent binding interactions between xenobiotic chemicals and soil. Soil Sci. 1997, 162, 858-874. 
Dec, J.; Bollag, J. M. Microbial release and degradation of catechol and chlorophenols bound to synthetic humic acid. Soil Sci. Soc. Am. J. 1988, 52, 1366-1371.

Dekker, R. F. H.; Richards, G. N. Hemicelluloses, their occurrence, purification, properties and mode of action. Adv. Carbohydr. Chem. Biochem. 1976, 32, 277-352.

Deobald and Crawford Lignicellulose biodegradation. In Hurst, C. J.; Knudsen, G. R.; McInerney, M. J.;

Stetzenbach, L. D.; Walter, M. V. (eds) Manual of Environmental Microbiology. America Society for Microbiology. 2000 .

Dinel, H.; Schnitzer, M.; Dumontet, S. Compost maturity: chemical characteristics of extractable lipids. Compost Sci. Util. 1996, 4, 16-25.

Ehrhardt, H. M.; Rehm, H. J. Phenol degradation by microorganisms adsorbed on activated carbon. Appl. Microbio. Biotechnol. 1985, 21, 32-36.

Ejlertsson, J.; Alnervik, M.; Svensson, B. H. Influence of water solubility, side chain degradability and side chain configuration on the degradation of phthalic acid esters under methanogenic conditions. Environ. Sci. Technol. 1997, $31,2761-2764$.

Eleazer, W. E.; Odle, W. S.; Wang, Y.; Barlaz, M. A. Biodegradability of municipal solid waste components in laboratory-scale landfills. Environ. Sci. Technol. 1997, 31, 911-917.

Evans, R.; Newman, R. H.; Roick, U. C.; Suckling, I. D.; Wallis, A. F. A. Changes in cellulose crystallinity during kraft pulping-comparison of infrared, X-ray diffraction and solid-state NMR results. Holzforschung 1995, 49, 498504.

Everett, D. H.; Powl, J. C. Adsorption in slit-like and cylindrical micropores in Henry's law region-model for microporosity of carbons. J. Chem. Soc. Faraday Trans. 1976, 72, 619-636.

Farrell, J.; Reinhard, M. Desorption of halogenated organics from model solids, sediments, and soil under unsaturated conditions. 1. Isotherms. Environ. Sci. Technol. 1994a, 28, 53-62.

Farrel, M.; Reinhard, M. Desorption of halogenated organics from model solids, sediments, and soil under unsaturated conditions. 2. Kinetics. Environ. Sci. Technol. 1994b, 28, 63-72.

Farrel, J.; Grassian, D.; Jones, M. Investigation of mechanisms contributing to slow desorption of hydrophobic organic compounds from mineral solids. Environ. Sci. Technol. 1999, 33, 1237-1243.

Feng, Y.; Park, J-H.; Voice, T. C.; Boyd, S. A. Bioavailability of soil-sorbed biphenyl to bacteria. Environ. Sci. Technol. 2000, 34, 1977-1984.

Gibson, D. T.; Koch, J. R.; Kallio, R. E. Oxidative degradation of aromatic hydrocarbons by microorganisms. I. Enzymatic formation of catechol from benzene. Biochemistry 1968a, 7, 2653-2662.

Gibson, D. T.; Koch, J. R.; Schuld, C. L.; Kallio, R. E. Oxidative degradation of aromatic hydrocarbons by microorganisms. II. Metabolism of halogenated aromatic hydrocarbons. Biochemistry. 1968b, 7, 3795-3802. 
Gibson, D. T.; Cardini, G. E.; Maseles, F. C.; Kallio, R. E. Incorporation of oxygen-18 into benzene by pseudomonas putida *. Biochemistry. 1970, 9, 1631-1635.

Gibson, D. In Microbial Degradation of Organic Compounds. Marcel Dekker Inc. New York and Basel. 1984, p 399-438.

Gibson, D. T.; Zylstra, G. J.; Chauhan, S. Biotransformations catalyzed by toluene dioxygenase from Pseudomonas putida F1, In Pseudomonas: Biotransformations, Pathogenesis, and Evolving Biotechnology. S. Kaplan (ed.)

American Society for Microbiology, Washington, D. C. 1989, p 121-132.

Gibson, D. T.; Parales, R. E. Aromatic hydrocarbon dioxygenases in environmental biotechnology. Curr. Opin. Biotech. 2000, 11, 236-243.

González-Vila, F. J.; Bautista, J. M.; Del Rio, J. C.; Martin, F. Evolution of chemicals within the dump profile in a controlled landfill. Chemosphere. 1995, 31, 2817-2825.

Grosser, R. J.; Friedrich, M.; Ward, D. M.; Inskeep, W. P. Effect of model sorptive phases on phenanthrene biodegradation: different enrichment conditions influence bioavailability and selection of phenanthrene-degrading isolates. Appl. Environ. Microbiol. 2000, 66, 2695-2702.

Gueer, L. A.; Shelton, D. R. Effect of inoculant strain and organic matter content on kinetics of 2, 4dicholorophenoxyacetic acid degradation in soil. Appl. Environ. Microbiol. 1992, 58, 1459-1465.

Guerin, W. F.; Boyd, S. A. Differential bioavailability of soil-sorbed naphthalene to two bacterial species. Appl. Environ. Microbiol. 1992, 58, 1142-1152.

Guerin, W. F.; Boyd, S. A. Maintenance and induction of naphthalene degradation activity in Pseudomonas putida and Alcaligenes sp. under different culture conditions. Appl. Environ. Microbiol. 1995, 61, 4061-4068.

Guerin, W. F.; Boyd, S. A. Bioavailability of naphthalene associated with natural and synthetic sorbents. Water Res. 1997, 31, 1504-1512.

Guthrie, E. A.; Bortiatynski, J. M.; van Heemst, J. D. H.; Richman, J. E.; Hardy, K. S.; Kovach, E. M.; Hatcher, P. G. Determination of $\left({ }^{13} \mathrm{C}\right)$ pyrene sequestration in sediment microcosms using flash prolysis-GC-MS and ${ }^{13} \mathrm{C}$ NMR. Environ. Sci. Technol. 1999, 33, 119-125.

Harms, H.; Zehnder, A. J. B. Influence of substrate diffusion on degradation of debenzofuran and 3chlorodibenzofuran by attached and suspended bacteria. Appl. Environ. Microbiol. 1994, 60, 2736-2745.

Harms, H.; Zehnder, A. J. B. Bioavailability of sorbed 3-chlorodibenzofuran. Appl. Environ. Microbiol. 1995, 61, 27-33.

Hatzinger, P. B.; Alexander, M. Effect of aging of chemicals in soil on their biodegradability and extractability. Environ. Sci. Technol. 1995, 29, 537-545.

Hatzinger, P.B.; Alexander, M. Biodegradation of organic compounds sequestered in organic solids or in nanopores within silica particles. Environ. Toxicol. Chem. 1997, 16, 2215-2221. 
Hortling, B.; Ranua, M.; Sundquist, J. Investigation of the residual lignin in chemical pulps. Part I. Enzymatic hydrolysis of the pulps and fractionation of the products. Nordic Pulp Paper Res. J. 1990, 1, 33-37.

Huang, W.; Weber, W. J. A distributed reactivity model for sorption by soils and sediments. 10. Relationships between desorption, hysteresis, and the chemical characteristics of organic domains. Environ. Sci. Technol. 1997, 31, 2562-2569.

Hunt, E. L.; Larsson, P. T.; Iversen, T. A CP/MAS C-13-NMR study of supermolecular changes in the cellulose and hemicellulose structure during Kraft pulping. Nordic Pulp Pap. Res. J. 2001, 16, 33-39.

International Union of Pured and Applied Chemistry, Division of Physical Chemistry Pure. Appl. Chem. 1972, 31, 577-638.

Johnson, S. E.; Herman, J. S.; Mills, A. L.; Hornberger, G. M. Bioavailability and desorption characteristics of aged, nonextractable atrazine in soil. Environ. Toxicol. Chem. 1999, 18, 1747-1754.

Karickhoff, S. W. Organic pollutant sorption in aquatic systems. J. Hydraul. Eng. 1984, 110, 707.

Karlsson, O.; Pettersson, B.; Westermark, U. The use of cellulases and hemicellulases to study lignin-cellulose as well as lignin-hemicellulose bonds in Kraft pulps. J. Pulp Paper Sci. 2001, 27, 196-201.

Kettunen, R. H.; Keskitalo, P.; Hoilijoki, T. H.; Rintala, J. A. Biological treatment for removal of organic material and ammonium from leachate at low temperatures. Waste Manage. Res. 1999,17, 487-492.

Kim, J. E.; Wang, C. J.; Bollag, J. M. Interaction of reactive and inert chemicals in the presence of oxidoreductases: Reaction of the herbicide bentazon and its metabolites with humic monomers. Biodegradation. 1998, 8, 387-392.

Kuhad, R. C.; Singh, A.; Eriksson, K. E. L. Microorganisms and enzymes involved in the degradation of plant fiber cell walls. In Advances in Biochemical Engineering/Biotechnology. Vol 57. Eriksson, K. E. L (ed). Springer, Germany. 1997, p 46-125.

Lamoureux, E. M.; Brownawell, B. J. Chemical and biological availability of sediment-sorbed hydrophobic organic contaminants. Environ. Toxicol. Chem. 1999, 18, 1733-1741.

Laor, Y.; Strom, P. F.; Farmer, W. J. The effect of sorption on phenanthrene bioavailability. J. Biotechnol. 1996, 51, 227-234.

LeBoeuf, E. J.; Weber, W. J. Jr. Macromolecular characteristics of natural organic matter. 2. Sorption and desorption behavior. Environ. Sci. Technol. 2000, 34, 3632-3640.

Lever, M. Colorimetric and fluorometric carbohydrate determination with para-hydroxybenzoic acid hydrazide. Biochem. Med. 1973, 274-281.

Lichtfouse, E.; Chenu, C.; Baudin, F. Resistant ultralaminae in soils. Org. Geochem. 1996, 25, 263-265.

Löser, C.; Seidel, H.; Hoffmann, P.; Zehnsdorf, A. Bioavailability of hydrocarbons during microbial remediation of a sandy soil. Appl. Microbiol. Biotechnol. 1999, 51, 105-111. 
Luthy, R. G.; Aiken, G. R.; Brusseau, M. L.; Cunninghan, S. D.; Gschwend, P. M.; Pignatello, J. J.; Reinhard, M.; Trainan, S. J.; Weber, W. J. Jr.; Westall, J. C. Sequestration of hydrophobic organic contaminants by geosorbents. Environ. Sci. Technol. 1997, 31, 3341-3347.

McGinley, P. M.; Katz, L. E.; Weber, W. J. A distributed reactivity model for sorption by soils and sediments. 2. Multicomponent systems and competitive effects. Environ. Sci. Technol. 1993, 27, 1524-1531.

Mersiowsky, I.; Weller, M.; Ejlertsson, J. Fate of plasticised PVC products under landfill conditions: a laboratoryscale landfill simulation reactor study. Wat. Res. 2001, 35, 3063-3070.

Micales, J. A.; Skog, K. E. The decomposition of forest products in landfill. Int. Biodeter. Biodegrad. 1997, 39, 145 158.

Miller, G. L.; Blum, R.; Glennon, W. E.; Burton, A. L. Measurement of carboxymethylcellulase activity. Anal. Biochem. 1960, 2, 127-132.

Mullings, R.; Parish, J. H. New reducing sugar assay for the study of cellulases. Enzyme Microb. Technol. 1984, 6, 491-496.

Nam, K.; Alexander, M. Role of nanoporosity and hydrophobicity in sequestration and bioavailability: tests with model solids. Environ. Sci. Technol. 1998, 32, 71-74.

Nam, K.; Alexander, M. Relationship between biodegradation rate and percentage of a compound that becomes sequestered in soil. Soil Biol. biochem. 2001, 33, 787-792.

Nguyen, R. T.; Harvey, H. R. In Nitrogen-containing macromolecules in the biosphere and geosphere. Stankiewicz, B. A.; Van Bergen, P. F. (eds) ACS Symposium Series 707: American Chemical Society: Washington, DC. 1998, p $88-112$.

Odier, E.; Monties, B. Absence of microbial mineralization of lignin in anaerobic enrichment cultures. Appl. Environ. Microbiol. 1983, 46, 661-665.

Park, J. W.; Kim, J. E.; Bollag, J. M. Effect of humic constituents on the transformation of chlorinated phenols and anilines in the presence of oxidoreductive enzymes or birmessite. Environ. Sci. Technol. 1999, 33, 2028-2034.

Park, J. W.; Dec, J.; Kim, J. E.; Bollag, J. M. Transformation of chlorinated phenols and anilines in the presence of humic acid. J. Environ. Qual. 2000, 29, 214-220.

Park, J. H.; Zhao, X.; Voice, T. C. Biodegradation of non-desorbable naphthalene in soils. Environ. Sci. Technol. 2001, 35, 2734-2740.

Pelczar, M. J. Jr.; Reid, R. D. In Microbiology. McGraw Press. New York. 1958, p102-103.

Pichler, M.; Kögel-Knabner, I. Chemolytic analysis of organic matter during aerobic and anaerobic treatment of municipal solid waste. J. Environ. Qual. 2000, 29, 1337-1344.

Pichler, M.; Knicker, H.; Kögel-Knabner, I. Changes in the chemical structure of municipal solid waste during 
composting as studied by solid-state dipolar dephasing and PSRE ${ }^{13} \mathrm{C}$ NMR and solid-state ${ }^{15} \mathrm{~N}$ NMR spectroscopy. Environ. Sci. Technol. 2000, 34, 4034-4038.

Pignatello, J. J.; Ferrandino, F. J.; Huang, L. Q. Elution of aged and freshly added herbicides from a soil. Environ. Sci. Technol. 1993, 27, 1563-1571.

Pignatello, J. J.; Xing, B. Mechanisms of slow sorption of organic chemicals to natural particles. Environ. Sci. Technol. 1996, 30, 1-11.

Rijnaarts, H. H. M.; Bachmann, A.; Jumelet, J. C.; Zehnder, A. J. B. Effect of desorption and intraparticle mass transfer on the aerobic biomineralization of $\alpha$-hexachlorocyclohexane in a contaminated calcareous soil. Environ. Sci. Technol. 1990, 24, 1349-1354.

Robinson, H. D.; Barr, M. J. Aerobic biological treatment of landfill leachates. Waste Manage. Res. 1999, 17, 478486.

Roper, J. C.; Sharkar, J. M.; Dec, J.; Bollag, J. M. Enhanced enzymatic removal of chlorophenols in the presence of co-substrates. Water Res. 1995, 29, 2720-2724.

Rutherford, D. W.; Chiou, C. T.; Kile, D. E. Influence of soil organic matter composition on the partition of organic compounds. Environ. Sci. Technol. 1992, 26, 336-340.

Sánchez-Monedero, M. A.; Roig, A.; Cegarra, J.; Bernal, M. P. Relationships between water-soluble carbohydrate and phenol fractions and the humification indices of different organic wastes during composting. Bioresource Technol. 1999, 70, 193-201.

Sarkar, J. M.; Malcolm, R. L.; Bollag, J. M. Enzymatic coupling of 2, 4-dichlorophenol to stream fulvic acid in the presence of oxidoreductases. Soil Sci. Soc. Am. J. 1988, 52, 688-694.

Scow, K. M.; Hutson, J. Effect of diffusion and sorption on the kinetics of biodegradation: theoretical considerations. Soil Sci. Soc. Am. J. 1992, 56, 119-127.

Scow, K. M.; Johnson, C. R. Effect of sorption on biodegradation of soil pollutants. 1997, Adv. Agron. 58, 1-56.

Senesi, N.; Testini, C. Adsorption of some nitrogenated herbicides by soil humic acids. Soil Sci. 1980, 130, 314-320.

Senior, E. In Microbiology of Landfill Sites. CRC press. Florida. 1990.

Sharrock, K. R. Cellulase assay methods: a review. J. Biochem. Biophy. Methods. 1988, 17, 81-106.

Shevchenko, S. M.; Bailey, G. W. Life after death: lignin-humic relationship reexamined. Crit. Rev. Env. Sci. Tec. 1996, 26, 95-153.

Stanier, R. Y.; Palleroni, N. J.; Doudoroff, M. The aerobic Pseudomonas: a taxonomic study. J. Gen. Microbiol. 1966, 43, 159-271.

Steinberg, S. M.; Pignatello, J. J.; Sawhney, B. L. Persistence of 1, 2-Dibromoethane in soil: entrapment in 
intraparticle micropores. Environ. Sci. Technol. 1987, 21, 1201-1208.

Stevenson, F. L. Humus chemistry: Genesis, Composition, Reactions, $2^{\text {nd }}$ Edition. John Wiley \& Sons, New York. 1994.

Tang, W. C.; White, J. C.; Alexander, M. Utilization of sorbed compounds by microorganisms specifically isolated for that purpose. Appl. Microbiol. Biotechnol. 1998, 49, 117-121.

Thorn, K. A.; Pettigrew, P. J.; Goldenberg, W. S. Covalent binding of aniline to humic substances. $2 .{ }^{15} \mathrm{~N}$ NMR studies of nucleophilic addition reactions. Environ. Sci. Technol. 1996, 30, 2764-2775.

Tuomela, M.; Vikman, M.; Hatakka, A.; Itavaara, M. Biodegradation of lignin in a compost environment: a review. Bioresource Technol. 2000, 72, 169-183.

U. S. EPA. Characterization for municipal solid waste in the United States: EPA 530-R-96-001: U. S. EPA: Washington, DC. 1996 update.

U. S. EPA. Municipal Solid Waste Factbook, Version 4.0: EPA 530-C-97-001: U. S. EPA: Washington. DC. 1997.

U .S. EPA Characterization of Municipal Solid Waste in the United States: US EPA/530-R-99-021; Office of Solid Waste, U.S. EPA: Washington, DC. 1999 update.

Venkataramani, E. S.; Ahlert, R. C.; Carbo, P. Biological treatment of landfill leachate. CRC Crit. Rev. Env. Contr. 1984, 14, 333-376.

Weber, W. J.; McGinley, P. M.; Katz, L. E. A distributed reactivity model for sorption by soils and sediments. 1. Conceptual basis and equilibrium assessments. Environ. Sci. Technol. 1992, 26, 1955-1962.

Weber, W. J. Jr.; Huang, W. A distributed reactivity model for sorption by soils and sediments. 4. Intraparticle heterogeneity and phase-distributed relationships under nonequilibrium conditions. Environ. Sci. Technol. 1996, 30, 881-888.

Wenzl, H. F. J. The chemistry of wood. In The Chemical Technology of Wood. Academic Press. New York and London. 1970, p92-156.

Werth, C. T.; Reinhard, M. Effects of temperature on trichloroethylene desorption from silica gel and natural sediments. 2. Kinetics. Environ. Sci. Technol. 1997, 31, 697-703.

White, J. C.; Hunter, M.; Nam, K.; Pignatello, J. J.; Alexander, M. Correlation between biological and physical availabilities of phenanthrene in soils and soil humin in aging experiments. Environ. Toxicol. Chem. 1999, 18, 17201727.

Xing, B.; McGill, W. B.; Dudas, M. J. Sorption of benzene, toluene, and o-xylene by collagen compared with nonprotein organic sorbent. Can. J. Soi. Sci. 1994, 74, 465-469.

Xing, B.; Pignatello, J. J. Bisolute competitive sorption between atrazine and other organic compounds in soils and model sorbents. Environ. Sci. Technol. 1996, 30, 2432-2440. 
Xing, B.; Pignatello, J. J. Dual-mode sorption of low-polarity compounds in glassy poly (vinyl chloride) and soil organic matter. Environ. Sci. Technol. 1997, 31, 792-799.

Young, T. M.; Weber, W. J. A distributed reactivity model for sorption by soils and sediments. 3. Effects of diagenetic processes on sorption energetics. Environ. Sci. Technol. 1995, 29, 92-97. 


\section{Chapter 3}

\section{Method Development}

In this chapter, experimental techniques used to evaluate bioavailability of toluene sorbed to MSW are described in detail. Preliminary data are included to give an overview of the development and gradual improvement of the experimental techniques.

\subsection{Anaerobic Bioavailability Test}

The objective of this test is to evaluate the potential of using consortia enriched from landfills in assessing bioavailability of HOCs sorbed to MSW component. The description of materials also applies to the other experiments in this chapter.

\subsubsection{Materials}

\section{Sorbents and Their Characterization}

Due to the complexity and heterogeneity of MSW, bioavailability tests are conducted with the major organic MSW components in pure form. Rabbit food (Manna Pro ${ }^{\circledR}$ Corporation, St. Louis, MO) contains both simple and complex carbohydrates as well as proteins in the form of alfalfa, wheat, soy and oat products, and it was used to represent food and yard waste. Poly (vinyl chloride) (PVC) (Sigma-Aldrich Milwaukee, WI) and high-density polyethylene (HDPE) were tested to represent glassy and rubbery polymers respectively. Newsprint and office paper were chosen to represent the major paper types in MSW.

Newsprint was collected from The News \& Observer Recycling Division (News \& Observer Publishing Co., Garner, NC). Office paper was collected from the NC State University recycling center. Office paper, newsprint and rabbit food were prepared as fresh and anaerobically degraded form to test the effect of refuse decomposition. All the sorbents except PVC were then dried and ground to powder by Thomas-Wiley laboratory mill and stored in desiccator until use. 
The characterization of sorbents is summarized in Table 3.1 (Wu et al. 2001).

\section{Sorbate}

${ }^{14} \mathrm{C}$ Labeled toluene $(2.8 \mathrm{mCi} / \mathrm{mmol}, 99 \%$ purity) was purchased from Sigma Chemical Co. (St. Louis, MO). For stock solutions, $1 \mathrm{mCi}$ radioactive toluene was mixed with $10 \mathrm{ml}$ non-labeled toluene (Reagent grade, Fisher Scientific, Pittsburgh, PA) to give a final concentration of $150325.33 \mathrm{dpm} / \mu \mathrm{L}$. Stock solutions are kept in a freezer at $-10{ }^{\circ} \mathrm{C}$ until use.

\section{Leachates}

Acidogenic leachate was produced by recirculating water through fresh residential refuse. The $\mathrm{pH}$ of the leachate was 4.9 and COD was around 22,000 mg/l. The acidogenic leachate has high concentrations of volatile fatty acids (VFA), which are summarized in Table 3.2. Methanogenic leachate was generated in the laboratory from decomposed refuse with $\mathrm{pH}$ around 8 and TOC around $120 \mathrm{mg} / \mathrm{l}$.

\subsubsection{Methods}

Prior to each test, test materials were sterilized by ${ }^{60} \mathrm{Co}$ gamma irradiation. Methanogenic leachate was filter-sterilized through $0.22 \mu \mathrm{m}$ nylon filter. To begin a test, the appropriate mass of a material was added to the serum bottle in triplicate. The materials were weighed out in an aluminum pan that had been wiped with ethanol and flamed to sterilize it. After the materials had been added to serum bottles, sterile, anaerobic methanogenic leachate was added to the bottles in anaerobic hood until bottles were filled to minimal headspace. Bottles were spiked with the appropriate volume of ${ }^{14} \mathrm{C}$ compound to obtain an activity of $2 \mu \mathrm{Ci}{ }^{14} \mathrm{C}$. The bottles were then sealed with the Teflon ${ }^{\mathrm{TM}}$ coated butyl rubber stoppers (West Company, Lionville, PA) and aluminum crimp caps. Six control bottles were included with leachate and no solids to quantify nonsorptive losses. After addition of ${ }^{14} \mathrm{C}$ test compound, bottles were aged in a tumbler for the duration of the aging period. 
TABLE 3.1 Characterization of Sorbents ${ }^{\text {a }}$

\begin{tabular}{|c|c|c|c|c|c|c|c|c|}
\hline Sorbent & $\begin{array}{c}\text { Cellulose } \\
(\%)\end{array}$ & $\begin{array}{c}\text { Hemicellulose } \\
(\%)\end{array}$ & $\begin{array}{l}\text { Lignin } \\
(\%)\end{array}$ & $\begin{array}{c}\text { Lipophilic } \\
\text { extractives (\%) }\end{array}$ & $\begin{array}{c}\text { Crude protein } \\
(\%)\end{array}$ & $\begin{array}{c}\text { Ash } \\
(\mathrm{wt} \%)\end{array}$ & $f_{o c}$ & $\begin{array}{l}\text { BET surface } \\
\text { area }\left(\mathrm{m}^{2} / \mathrm{g}\right)\end{array}$ \\
\hline Poly (vinyl chloride) & $\mathrm{N} / \mathrm{A}$ & $\mathrm{N} / \mathrm{A}$ & $\mathrm{N} / \mathrm{A}$ & $\mathrm{N} / \mathrm{A}$ & $\mathrm{N} / \mathrm{A}$ & 0.00 & 0.389 & 0.8 \\
\hline High density polyethylene & N/A & N/A & N/A & N/A & N/A & 0.01 & 0.876 & 0.6 \\
\hline Fresh office paper & 64.7 & 13.0 & 0.93 & 0.7 & 0.31 & 11.6 & 0.373 & 2.8 \\
\hline Degraded office paper & 36.2 & 6.9 & 4.8 & 3.3 & 4.99 & 38.4 & 0.278 & 6.0 \\
\hline Fresh newsprint & 48.3 & 18.1 & 22.1 & 1.6 & 0.44 & 2.0 & 0.451 & 2.6 \\
\hline Degraded newsprint & 35.1 & 16.0 & 32.3 & 1.4 & 3.74 & 6.4 & 0.455 & 3.4 \\
\hline Fresh rabbit food & 30.6 & 15.4 & 9.5 & 4.9 & 18.1 & 7.7 & 0.423 & 0.6 \\
\hline Degraded rabbit food & 7.1 & 5.7 & 25.2 & 4.5 & 20.6 & 34.5 & 0.329 & 0.5 \\
\hline
\end{tabular}

${ }^{a}$ Values are averages of replicate analyses. ${ }^{b}$ N/A: not analyzed

TABLE 3.2 VFA Analysis of Acidogenic Leachate ${ }^{\text {a, } b}$

\begin{tabular}{|c|c|c|c|c|c|c|c|c|c|c|}
\hline $\begin{array}{l}\text { Sample } \\
\text { number }\end{array}$ & $\begin{array}{l}\text { acetic } \\
\text { acid }\end{array}$ & $\begin{array}{l}\text { propionic } \\
\text { acid }\end{array}$ & $\begin{array}{c}\text { i-butyric } \\
\text { acid }\end{array}$ & $\begin{array}{c}\text { Butyric } \\
\text { acid }\end{array}$ & $\begin{array}{c}\text { 2-methyl } \\
\text { butyric acid }\end{array}$ & $\begin{array}{c}\text { i-valeric } \\
\text { acid }\end{array}$ & $\begin{array}{c}\text { Valeric } \\
\text { Acid }\end{array}$ & $\begin{array}{c}\text { i-caproic } \\
\text { acid }\end{array}$ & $\begin{array}{c}\text { caproic } \\
\text { acid }\end{array}$ & $\begin{array}{c}\text { heptanoic } \\
\text { acid }\end{array}$ \\
\hline 1 & 1658 & 1571 & 101 & 3862 & 52 & 61 & 1774 & 22 & 337 & ND \\
\hline 2 & 1886 & 1675 & 141 & 3736 & 56 & 66 & 1717 & 21 & 317 & ND \\
\hline
\end{tabular}

${ }^{a}$ Sample 1 and 2 were duplicate acidogenic leachate samples. ${ }^{\mathrm{b}}$ Concentration in $\mathrm{mg} / \mathrm{L}$. 
Following aging, bottles were removed from the tumbler. Duplicate $0.5 \mathrm{ml}$ samples were taken from the aqueous phase. This step quantified the amount of test compound sorbed to the solid. After sample removal, as much additional liquid as possible was removed from bottle using a disposable syringe. The volume removed was replaced with inoculum from a culture known to degrade o-xylene (enriched from contaminated sediment obtained from a sandy zone of an aquifer in Pensacola, FI. (Edwards and Grbic-Galic 1994)), leaving a $10 \mathrm{ml}$ headspace for gas accumulation. The concentration of the test compound was adjusted using the ${ }^{14} \mathrm{C}$ stock solution to be the same in the inoculum as in the aqueous phase of the test bottles to prevent any additional sorption and desorption.

For the six control bottles, three were inoculated with the same amount of microorganisms. The inoculum was autoclaved and added to the other three abiotic control bottles. These three abiotic control bottles were set up to monitor the abiotic loss of the test compound during incubation.

Following inoculation. Three positive controls, three bioavailability tests and three abiotic controls were maintained at $37^{\circ} \mathrm{C}$ for 4 months. Gas production was monitored by venting the headspace of bottles directly into gasbags. ${ }^{14} \mathrm{CH}_{4}$ and ${ }^{14} \mathrm{CO}_{2}$ and volatile ${ }^{14} \mathrm{C}$-test compound were quantified using gas trapping protocol.

\subsubsection{Experimental Results}

The bioavailability result was shown in Table 3.3 (Pelton 2000). The cumulative o-xylene recovery was low in all bottles over 1 month monitoring period. The overall recovery for bioavailability bottles were around $1 \%$ with majority of the recovery representing volatilization of o-xylene, which was trapped on the $\mathrm{ORBO}^{\mathrm{TM}}$ tubes. The biodegradation rate in biological control bottles was also very low. Of the $7 \%$ recovery, less than $10 \%$ is ${ }^{14} \mathrm{CH}_{4}$ and ${ }^{14} \mathrm{CO}_{2}$. The recovery of volatile o-xylene on the $\mathrm{ORBO}^{\mathrm{TM}}$ tubes during each trapping period verified that there was o-xylene available to the bacteria in each bottle, but it was hard to argue that there was degradation occurring based on extremely low ${ }^{14} \mathrm{CH}_{4}$ and ${ }^{14} \mathrm{CO}_{2}$ produced. 
TABLE 3.3 Anaerobic Bioavailability of o-xylene Aged One Month on Degraded Newsprint

\begin{tabular}{|c|c|c|c|c|c|c|c|c|c|c|}
\hline \multirow{2}{*}{\multicolumn{2}{|c|}{ Bottle number }} & \multirow{2}{*}{$\begin{array}{l}\text { Initial } \\
\text { dpm } \\
\text { added }\end{array}$} & \multirow{2}{*}{$\begin{array}{c}\text { dpm } \\
\text { removed } \\
\text { with } \\
\text { leachate }\end{array}$} & \multirow{2}{*}{$\begin{array}{l}\text { dpm } \\
\text { added } \\
\text { with } \\
\text { inoculum }\end{array}$} & \multicolumn{4}{|c|}{ dpm trapped } & \multirow{2}{*}{$\begin{array}{l}\text { Cumulative } \\
{ }^{14} \mathrm{CO}_{2}{ }^{14} \mathrm{CH}_{4} \\
\text { recovery }(\%)\end{array}$} & \multirow{2}{*}{$\begin{array}{c}\text { Cumulative } \\
\text { recovery } \\
(\%)\end{array}$} \\
\hline & & & & & ${ }^{14} \mathrm{CO}_{2}$ & ${ }^{14} \mathrm{CH}_{4}$ & ORBO & Total & & \\
\hline \multirow{3}{*}{$\begin{array}{l}\text { Bioavail- } \\
\text { ability }\end{array}$} & 1 & 1062959 & 94197 & 50334 & 0 & 0 & 19223 & 19223 & 0 & 1.89 \\
\hline & 2 & 1036385 & 88498 & 50334 & 0 & 986 & 14140 & 15126 & 0.099 & 1.52 \\
\hline & 3 & 1062959 & 81867 & 50334 & 571 & 0 & 17017 & 17588 & 0.055 & 1.76 \\
\hline \multirow{3}{*}{$\begin{array}{l}\text { Positive } \\
\text { control }\end{array}$} & 1 & 1062959 & 0 & 0 & 301 & 2115 & 71320 & 73736 & 0.23 & 6.94 \\
\hline & 2 & 1062959 & 0 & 0 & 536 & 6483 & 73386 & 80405 & 0.66 & 7.56 \\
\hline & 3 & 1062959 & 0 & 0 & 324 & 2211 & 80858 & 83273 & 0.23 & 7.85 \\
\hline \multirow{3}{*}{$\begin{array}{l}\text { Abiotic } \\
\text { Control }\end{array}$} & 1 & 1062959 & 90146 & 54317 & 0 & 0 & 9542 & 9542 & 0 & 0.93 \\
\hline & 2 & 1062959 & 92985 & 54317 & 0 & 0 & 9645 & 9645 & 0 & 0.94 \\
\hline & 3 & 1062959 & 98349 & 54317 & 0 & 0 & 10378 & 10378 & 0 & 1.02 \\
\hline
\end{tabular}

\subsubsection{Conclusions and Recommendations}

1 O-xylene is a volatile compound. Previous test showed that significant loss occurred when using gray Teflon ${ }^{\mathrm{TM}}$ coated butyl rubber stopper to seal serum bottle during long time aging. The loss during aging will introduce uncertainties into the mass balance. To avoid this, the bottles should then be sealed in a way that allows for the headspace to be vented without opening the bottle.

2 After three months of incubation. It was found that large amount of gas was produced in abiotic control bottle; indicating $\gamma$ irradiation prior to loading the bottle was ineffective. Contamination may occur during weighing and spiking procedures.

\subsubsection{Improvements}

Based on the anaerobic bioavailability test, the experimental design was improved in the following aspects.

1 Serum bottles with Teflon ${ }^{\mathrm{TM}}$ coated rubber stoppers were replaced by $160 \mathrm{ml}$ flame-sealable ampoules (Prism Glass, RTP, NC) to avoid volatile loss. After placing the solid and liquid into the bottle and spiking toluene, the bottle was quickly flame sealed with a hand torch.

2 Although it is ideal to study bioavailability in landfill under anaerobic conditions, an aerobic 
system was used considering low ${ }^{14} \mathrm{CO}_{2}$ and ${ }^{14} \mathrm{CH}_{4}$ production in anaerobic tests. It is well accepted that sorbed compounds cannot be degraded without being released to the aqueous phase. Therefore bioavailability of organic compounds is limited by desorption instead of types of microorganisms.

3 Much higher toluene concentrations are used although the typical toluene concentration in landfill leachates is between $0-7500 \mu \mathrm{g} / \mathrm{l}$ (Christenssen et al. 1994). The reasons are: the flux of energy from degradation of insufficient substrate cannot sustain the biomass; in lower substrate condition, the concentration may not be sufficient to induce enzyme production. In addition, following the bioavailability test, a series of extractions will be performed to determine the association of non-bioavailable compounds with solids. Lower initial concentrations make HOCs hard to detect during these analyses.

\subsection{Aerobic Bioavailability Test}

The objective of this test is to evaluate the potential of using redesigned aerobic system in assessing bioavailability of toluene in MSW landfill.

\subsubsection{Methods}

\section{Sample Aging}

Solid materials were weighted into $160 \mathrm{ml}$ ampoule; $60 \mathrm{ml}$ of growth medium was then added to wet the solid. $20 \mu \mathrm{l}$ of stock solution, which contained approximately $3 \times 10^{6} \mathrm{dpm}$ of labeled toluene was spiked to the bottom of each ampoule, resulting in a final liquid phase toluene concentration of $100-200 \mathrm{mg} / \mathrm{l}$. The ampoule was quickly flame sealed to avoid volatilization loss. The flame-sealed samples were sterilized with $2.2 \mathrm{Mrad}$ of gamma irradiation from a ${ }^{60} \mathrm{Co}$ source. Then samples were completely mixed in a New Brunswick Innova 2300 shaker (Edison, $\mathrm{NJ}$ ) for different time periods.

\section{Bacterial Strains and Growth Conditions}

Strain Pseudomonas putida F1 (from Dr. Mike Hyman, North Carolina State University, 
Raleigh, NC) was grown at $30 \pm 1{ }^{\circ} \mathrm{C}$ in medium containing $\mathrm{H}_{3} \mathrm{BO}_{3} 1.43 \mathrm{mg}, \mathrm{ZnSO}_{4} \cdot \mathrm{H}_{2} \mathrm{O} 0.32 \mathrm{mg}$, $\mathrm{CoCl}_{2} \cdot 4 \mathrm{H}_{2} \mathrm{O} 0.1 \mathrm{mg}, \mathrm{CuSO}_{4} \cdot \mathrm{H}_{2} \mathrm{O} 0.08 \mathrm{mg}, \mathrm{Na}_{2} \mathrm{MoO}_{4} \cdot 2 \mathrm{H}_{2} \mathrm{O} 0.05 \mathrm{mg}, \mathrm{KH}_{2} \mathrm{PO}_{4} 4.2215 \mathrm{~g}, \mathrm{~K}_{2} \mathrm{HPO}_{4}$ $3.368 \mathrm{~g}, \mathrm{CaCl}_{2} \cdot 2 \mathrm{H}_{2} \mathrm{O} 0.05 \mathrm{~g}, \mathrm{FeCl}_{3} 0.005 \mathrm{~g}, \mathrm{MgSO}_{4} \cdot 7 \mathrm{H}_{2} \mathrm{O} 0.201 \mathrm{~g}, \mathrm{NH}_{4} \mathrm{NO}_{3} 0.5 \mathrm{~g}$, disodium EDTA $0.01 \mathrm{~g}$ per liter of D. I. water. To prepare an inoculum of this bacterium, $25 \mathrm{ml}$ sterile medium was inoculated and the organisms were grown in an incubator shaker $\left(30 \pm 1^{\circ} \mathrm{C}, 150\right.$ $\mathrm{rpm}$ ) with $12.5 \mu \mathrm{l}$ toluene supplemented as substrate. After $24 \mathrm{hr}, 0.5 \mathrm{ml}$ of the culture was transferred into another $25 \mathrm{ml}$ of sterile growth medium and incubated for $24 \mathrm{hr}$. The cells were washed twice and resuspended in $\mathrm{NaH}_{2} \mathrm{PO}_{4}-\mathrm{Na}_{2} \mathrm{HPO}_{4} \mathrm{pH} 7$ buffer before use.

\section{Bioavailability Test}

The bioavailability of a pollutant to bacteria can be assessed by monitoring the degradation of toluene. In this study, a pure culture of $P p F 1$ was used as toluene degrader. While this pure culture system lacks the complexity of natural landfill communities or those in soil, it is a reasonable starting point for the development and validation of desorption and bioavailability processes.

The apparatus for bioavailability testing is shown in Fig 3.1. After the compounds had aged for 1 day, 1 month, 6 months and 1 year, triplicate samples were broken at the score mark. One ml of aqueous phase was quickly withdrawn to measure toluene concentration. Duplicate solid-free blank sample was then prepared by adding stock solution to attain the same liquid phase concentration as aged samples. The triplicate samples and two blanks were inoculated with $3 \mathrm{ml}$ of a suspension of a toluene mineralizing bacterium; strain $P p F 1$ to give $1.5 \times 10^{8}$ cells $/ \mathrm{ml}$. Cell number was determined by optical density of the culture according to the CFU-optical density calibration curve (Fig C-1). After inoculation, the bottle was sealed with a stainless Swagelok ${ }^{\mathrm{TM}}$ cap. Three stainless steel needles, one 18G, 2 inches, two 18G, 6 inches were welded through the top of the cap beforehand. Two sterile $12 \times 75 \mathrm{~mm}$ glass vials were attached to the two long needles and put into liquid phase. The ends of the two needles were kept in touch with the bottom of glass vials. $2 \mathrm{ml}$ of $2 \mathrm{~N} \mathrm{NaOH}$ was injected into one vial as absorbent of evolved ${ }^{14} \mathrm{CO}_{2}, 1 \mathrm{ml}$ of $30 \%$ hydrogen peroxide and $0.5 \mathrm{ml}$ of $\mathrm{FeCl}_{2}$ were injected to the other vial to 
provide oxygen for bacteria growth. It was verified that $\mathrm{FeCl}_{2}$ can catalyze the decomposition of hydrogen peroxide and the rate of decomposition is concentration dependent (Schumb 1955). Since BOD of solid materials are quite different, the concentration of the catalyst was also changed in order to meet the oxygen demand of both sorbent and substrate. Two push button syringe valves were attached to the hubs of the stainless steel needle to prevent volatilie loss.

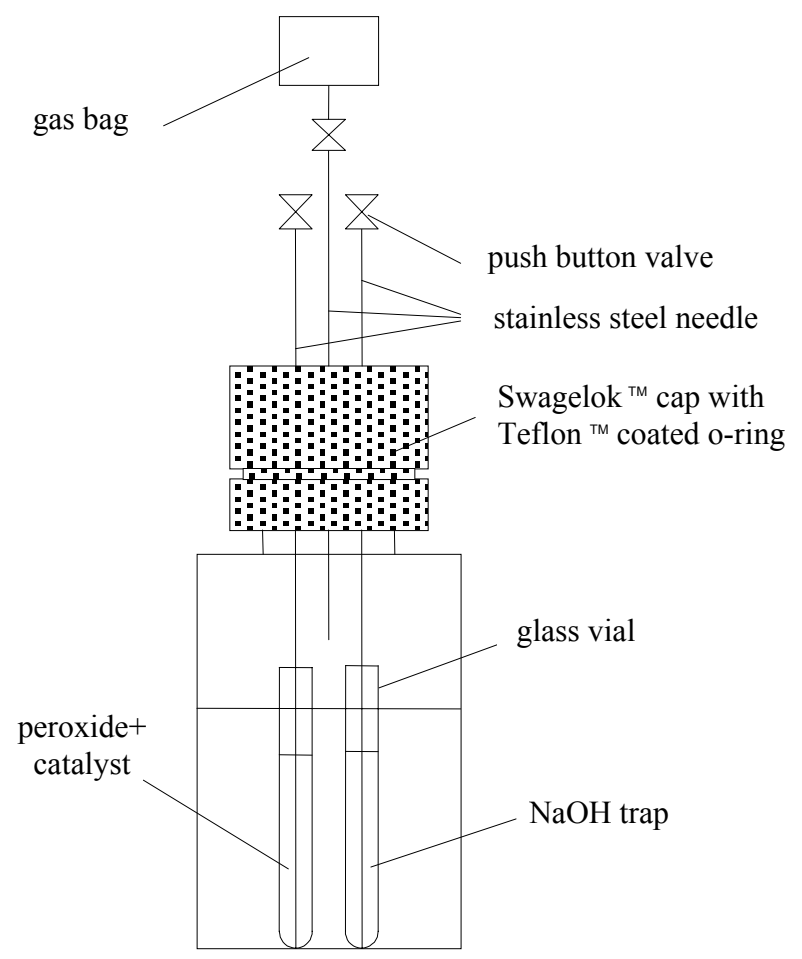

FIGURE 3.1 Experimental design for aerobic toluene bioavailability test.

Glass vial dimension $10 \times 75 \mathrm{~mm}$, two long stainless steel needles: $18 \mathrm{G}, 15 \mathrm{~cm}$. One short stainless steel needle: $18 \mathrm{G}$, $5 \mathrm{~cm}$.

Supplying oxygen through a double layer Tedlar gasbag full of oxygen instead of using peroxide was also tested. Once the oxygen in the ampoule was depleted, the vacuum formed inside would suck oxygen into the ampoule from the gasbag. The experimental result was unsuccessful. The vacuum formed could not overcome the resistance along tubings as well as connectors between the ampoule and the gasbag. Not enough oxygen was detected in ampoule $(<1 \mathrm{mg} / \mathrm{L})$. Therefore, peroxide was still used as oxygen source, the Tedlar gasbag was kept to collect any excess oxygen produced by hydrogen peroxide. The bioavailability bottles were incubated at $30 \pm 1^{\circ} \mathrm{C}$ in 
an incubator shaker (New Brunswick Scientific C24 Classic series, Edison, NJ) operating at 130 rpm. Periodically, the $\mathrm{NaOH}$ was withdrawn and fresh $\mathrm{NaOH}$ was injected through the needle and ${ }^{14} \mathrm{CO}_{2}$ was determined by adding $6 \mathrm{ml}$ of scintillation cocktail and counted by scintillation counter (TRI-CARB 2100TR Packard Instrument Company, Downers Grove, IL). Because of high base content of the sample, they were always stored overnight in refrigerator before analyzing to reduce the effect of chemiluminescence. Hydrogen peroxide was replaced in the same way. To maintain a DO level higher than $3 \mathrm{mg} / \mathrm{L}$, gas phase $\mathrm{O}_{2}$ concentration is monitored by $\mathrm{GC}$. The frequency of $\mathrm{H}_{2} \mathrm{O}_{2}$ replacement was determined by the oxygen demand of different materials.

\section{Analysis of Residual ${ }^{14} \mathrm{C}$ at Termination of Bioavailability Test}

After the bioavailability test, the bioavailability samples are subjected to a series of extractions to analyze the residual ${ }^{14} \mathrm{C}$ distribution (Fig 3.2). Triplicate samples of each material were centrifuged at $3000 \mathrm{rpm}$ for 10 min (Eppendorf centrifuge 5810, Brinkmann Instruments Inc., Westbury N.Y.). Supernatant was removed by decanting from solids and analyzed for dissolved ${ }^{14} \mathrm{C}$. Initially, $25 \mathrm{ml}$ benzyl alcohol was added to the solid. Sorbent and benzyl alcohol were mixed and shaken for three days. Benzyl alcohol extractions were repeated until no more counts were recoverable from the solid. The samples were washed with D. I. water several times to remove benzyl alcohol and then subjected to a series of $\mathrm{NaOH}$ extraction until the concentration of the extract was lower than $100 \mathrm{dpm} / \mathrm{ml} .0 .1 \mathrm{~N} \mathrm{NaOH}$ extracts were combined.

$\mathrm{NaOH}$ extracts were acidified to $\mathrm{pH} 1.5$ by $6 \mathrm{~N} \mathrm{HCl}$ to precipitate humic acid. The precipitate was collected by centrifugation and resuspended in $\mathrm{NaOH}$. Duplicate $0.5 \mathrm{ml}$ samples were taken to measure radioactivity and TOC (Shimadzu TOC 5000A analyzer, Columbia, MD), humic acid fraction was then fractionated by HPSEC according to different molecular weight.

The supernatant from the $\mathrm{pH}=1.5$ acidification step was passed through a $54 \mathrm{ml}$ glass column packed with $50 \mathrm{ml} \mathrm{DAX8}{ }^{\mathrm{TM}}$ resin $\left(\mathrm{k}^{\prime}{ }_{0.5 \mathrm{r}}=5\right)$. Flow rate was $12.5 \mathrm{ml} / \mathrm{min}$. Fulvic acid, which was retained on the resin, was eluted with $400 \mathrm{ml}$ of $0.1 \mathrm{~N} \mathrm{NaOH}$ at $1.5 \mathrm{ml} / \mathrm{min}$ by peristaltic pump. Effluent was collected and fractionated by HPSEC. Duplicate $0.5 \mathrm{ml}$ sample was taken to 
determine radioactivity. Nonsorbed effluent was non-humic substance; samples were taken to measure TOC and radioactivity.

Undissolved humin was collected and that part was termed as humin and burned in tube furnaces at $875^{\circ} \mathrm{C} ;{ }^{14} \mathrm{CO}_{2}$ was trapped in four successive sodium hydroxide traps.

\subsubsection{Experimental Results}

The results of aerobic bioavailability are shown in Fig 3.4 and Fig 3.5. The extent of biodegradation varied markedly among sorbents and was correlated with the sorbent's chemical characteristics (Table 3.4). In general, toluene bioavailability was reduced by aging. Analysis of the solid phase at the termination of bioavailability tests revealed that ${ }^{14} \mathrm{C}$ was present in all three major forms of humic substances; humic acid, fulvic acid and humin. High-performance size exclusion chromatography showed that ${ }^{14} \mathrm{C}$ in humic and fulvic acid fractions was present in molecular size fractions greater than that of free toluene. However, it was also observed that after $\gamma$-irradiation approximately $46 \%$ of the added toluene was converted from a spargeable compound to a mixture of non-spargeable materials (Table 3.4). The mechanisms of reactions occurred during irradiation of toluene were reported by Weiss and Rao (1965), Weiss and Collins $(1964,1966)$. As a result, it is apparent that ${ }^{14} \mathrm{C}$-toluene was not the only initial compound leading to the results with $\gamma$-irradiation presented in Table 3.4.

TABLE 3.4 Comparison of Toluene Bioavailability with and without Gamma Irradiation ${ }^{\text {a }}$

\begin{tabular}{|c|c|c|c|c|c|c|c|c|}
\hline Sorbent & $\begin{array}{c}\text { Aging } \\
\text { time (d) }\end{array}$ & $\begin{array}{c}\text { Gamma } \\
\text { irradiation }\end{array}$ & $\begin{array}{c}\text { Sorbed } \\
(\%)^{\mathrm{b}}\end{array}$ & $\begin{array}{c}{ }^{14} \mathrm{CO}_{2} \\
(\%)\end{array}$ & $\begin{array}{c}\text { Particulate } \\
\text { and cell mass } \\
(\%)\end{array}$ & $\begin{array}{c}\text { Non-volatile } \\
{ }^{14} \mathrm{C} \text { in liquid } \\
(\%)\end{array}$ & $\begin{array}{c}\text { Solvent } \\
\text { extractable } \\
(\%)\end{array}$ & $\begin{array}{c}\text { Total } \\
\text { Recovery } \\
(\%)\end{array}$ \\
\hline HDPE & 1 & Yes & $\begin{array}{c}46.50 \\
(2.01)\end{array}$ & $\begin{array}{c}63.05 \\
(1.11)\end{array}$ & $\begin{array}{c}14.43 \\
(0.79)\end{array}$ & $\begin{array}{c}14.70 \\
(0.49)\end{array}$ & $\begin{array}{c}6.29 \\
(0.07)\end{array}$ & $\begin{array}{c}9.00 \\
(1.01)\end{array}$ \\
\hline HDPE & 1 & No & $\begin{array}{c}76.51 \\
(0.72)\end{array}$ & $\begin{array}{c}71.12 \\
(1.89)\end{array}$ & $\begin{array}{c}17.07 \\
(0.67)\end{array}$ & $\begin{array}{c}2.34 \\
(0.11)\end{array}$ & $\mathrm{d}$ & $\mathrm{d}$ \\
\hline
\end{tabular}

${ }^{a}$ Data are averages of triplicate samples. Standard deviations are given in parentheses. Percentages are based on total amount of toluene added initially corrected for volatile loss. ${ }^{b}$ Radioactivity in solid phase before inoculation. Percentages are based on total amount of toluene without correction of volatile loss. ${ }^{\mathrm{c}}$ Solvent is benzyl alcohol. ${ }^{\mathrm{d}}$ Not analyzed. 


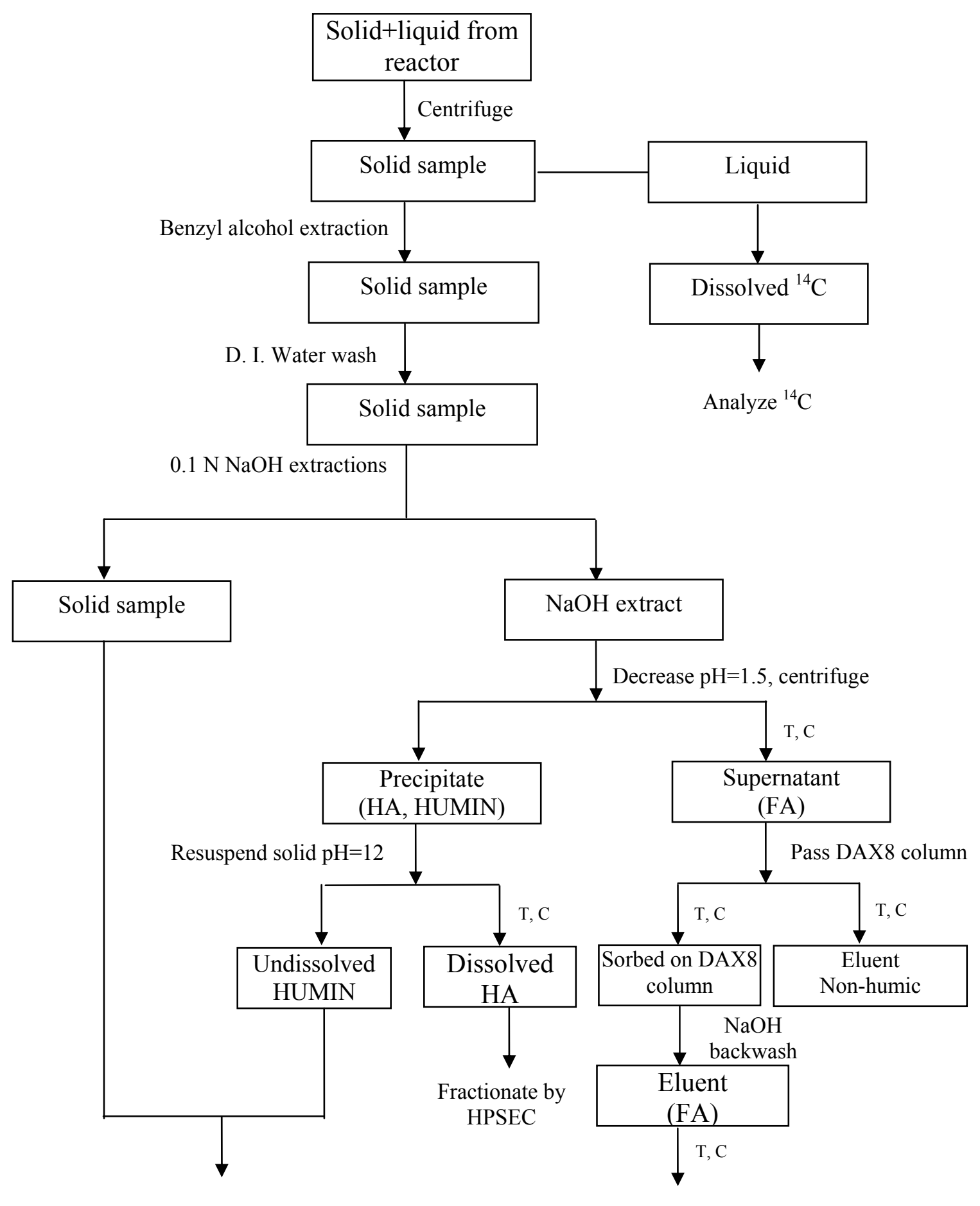

Combustion

Fractionate by HPSEC

FIGURE 3.2 Analysis of residual ${ }^{14} \mathrm{C}$ after termination of bioavailability test.

T: Measure total organic carbon. C: measure radioactivity. 


\subsubsection{Improvements}

Aging protocol was revised to eliminate the $\gamma$-irradiation of toluene. Sorbents were sterilized 2.2 Mrad of gamma irradiation from a ${ }^{60} \mathrm{Co}$ source. To each sorbent, $60 \mathrm{~mL}$ of sterile growth medium was added aseptically in the laminar flow hood. Upon the addition of toluene stock solution with sterile micro-liter syringe, the ampoules were quickly flame sealed and aged for 1 , 30, and 180 days. No modification was made for other experimental techniques.

\subsection{Preliminary Test}

\subsubsection{Toxicity Assay of Acidogenic Leachate}

Acidogenic leachate has high concentrations of carboxylic acids as shown in table 3.2. To conduct bioavailability tests in acidogenic leachate, it is necessary to first evaluate its toxicity to strain $P p F 1$.

\section{Methods}

$500 \mathrm{ml}$ acidogenic leachate was adjusted to $\mathrm{pH} 7$ by 50/50 (w/w) $\mathrm{NaOH}$. After precipitation, the leachate was filtered through $0.45 \mu \mathrm{m}$ filter to remove particulates. Chemicals (trace minerals, $\mathrm{K}_{2} \mathrm{HPO}_{4}, \mathrm{KH}_{2} \mathrm{PO}_{4}$ were added according to medium formula to make the acidogenic leachate suitable for $P p F 1$ growth. The leachate was then sterilized by $2.2 \mathrm{Mrad}$ of gamma irradiation from a ${ }^{60} \mathrm{Co}$ source. Triplicate undiluted $50 \mathrm{ml}$ sterile acidogenic leachate samples were added to $250 \mathrm{ml}$ sterile Erlenmeyer flasks (Fig 3.3). Triplicate acidogenic leachate samples were diluted to $50 \%$ of original concentration by sterile D. I. water. Another set of triplicate samples was diluted to make the final concentration $75 \%$ of the original leachate. The nine flasks were then inoculated with $P p F 1$ and incubated at $30 \pm 1{ }^{\circ} \mathrm{C}$. Peroxide was changed daily as oxygen source. Oxygen concentration in aqueous phase was checked with Chemets self-filling dissolved oxygen ampoule (CHEMetrics Inc., Calverton, VA) to make sure oxygen concentrations were greater than $3 \mathrm{mg} / \mathrm{L}$. This concentration was selected based on the research of Shuler and Kargi (1992) and Chiang et al. (1989), who found a threshold DO concentration of $2 \mathrm{mg} / \mathrm{L}$ and $0.4 \mathrm{mg} / \mathrm{L}$ respectively exist for aerobic BTX degradation. $\mathrm{CO}_{2}$ produced was trapped in $10 \mathrm{ml} 1 \mathrm{~N} \mathrm{CO}_{2}$ 
free $\mathrm{NaOH}$. Growth of the bacteria was monitored by measuring the inorganic carbon in $\mathrm{NaOH}$ trap with TOC analyzer (Shimadzu TOC 5000A). Two blanks without inoculation were also prepared to monitor abiotic background.

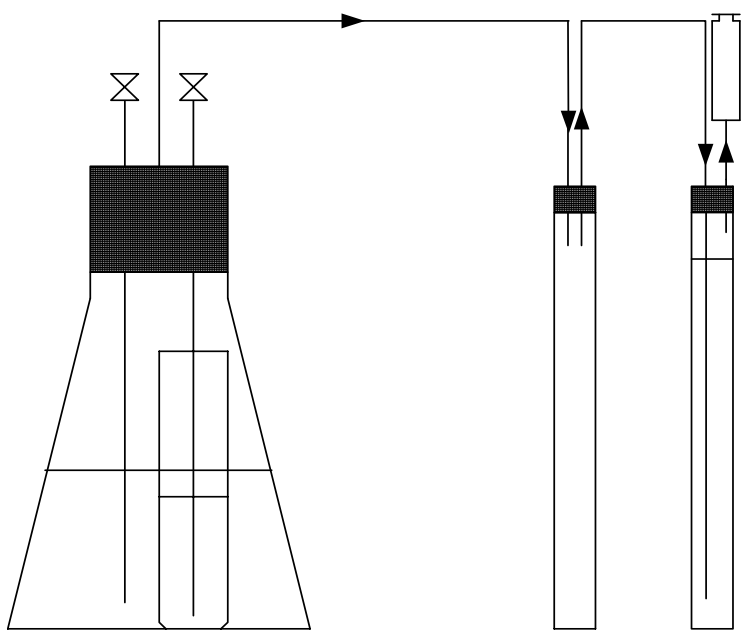

FIGURE 3.3 Experimental design for acidogenic leachate toxicity assay

\section{Experimental Results}

Most leachate toxicity assays that concluded acidogenic leachate was toxic were based on shortterm experiments, which lasted 1 or 2 days. However, this study showed acidogenic leachate was not toxic to PpF1 (Fig 3.4). Lag period was present in biodegradation, this may be because the inoculum was grown with toluene as substrate, and it took time for bacteria to develop enzymes to degrade carboxylic acids. Lag period was found proportional to the concentration of leachate. After 48 hours, bacteria acclimated to high concentration of carboxylic acid and began to metabolized leachate quickly.

Due to its high COD (around 22,000 mg/l), it will be very difficult to meet the necessary oxygen demand in acidogenic leachate in a sealed system. Because of this, bioavailability test will not be performed in acidogenic leachate. 


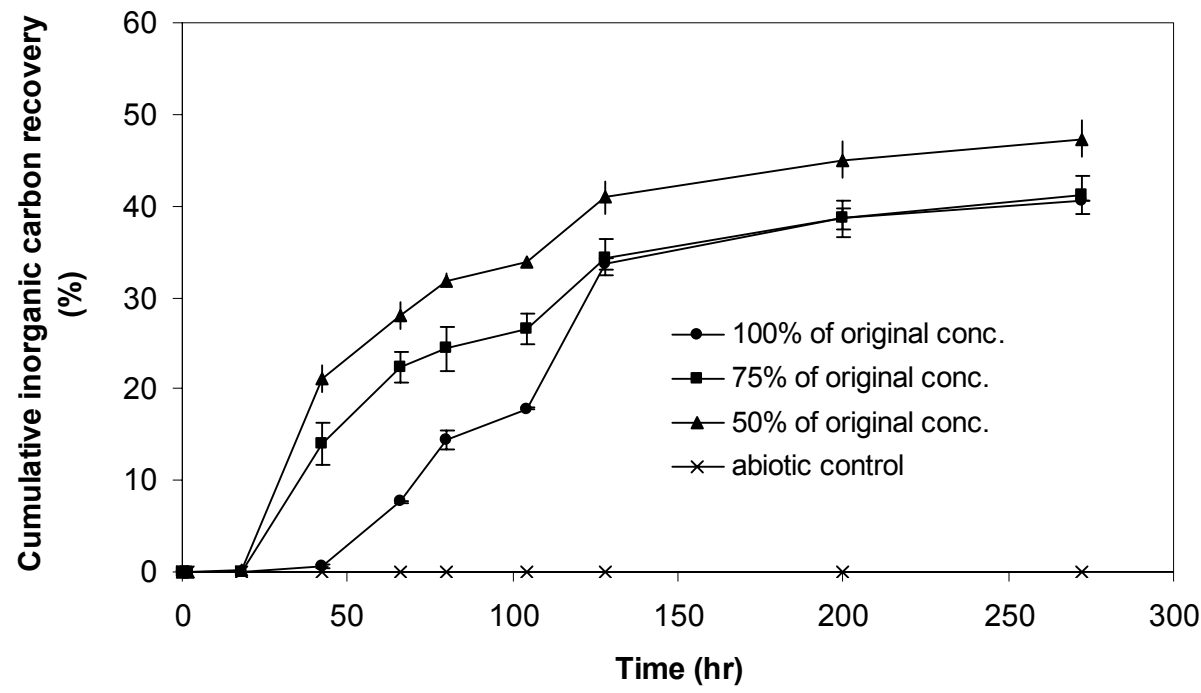

FIGURE 3.4 Toxicity assay of acidogenic leachate.

Data are averages of triplicate samples. Error bars represent standard deviations.

\subsubsection{Bioavailability Test in Methanogenic Leachate}

The objective of this test is to evaluate the potential of conducting bioavailability tests in methanogenic leachate

\section{Materials and Methods}

$60 \mathrm{ml}$ methanogenic leachate was adjusted to $\mathrm{pH} 7$ by adding $6 \mathrm{~N} \mathrm{HCl}$. The leachate was then filtered through $0.45 \mu \mathrm{m}$ filter to remove particulates. Chemicals (trace minerals, $\mathrm{K}_{2} \mathrm{HPO}_{4}$, $\mathrm{KH}_{2} \mathrm{PO}_{4}$ were added according to medium formula to supply necessary nutrients for $P p F 1$ growth. $60 \mathrm{ml}$ filtered methanogenic leachate was added to $100 \mathrm{ml}$ ampoule together with $3 \mathrm{~g}$ HDPE. $10 \mu \mathrm{L}$ toluene stock solution was spiked. The ampoules were quickly flame sealed and sterilized by $2.2 \mathrm{Mrad}$ of gamma irradiation from a ${ }^{60} \mathrm{Co}$ source. Duplicate blank samples with only methanogenic leachate and toluene in ampoule were prepared the same way. After aging, the four ampoules were then inoculated with $P p F 1$ and incubated at $30 \pm 1{ }^{\circ} \mathrm{C}$. Peroxide was changed daily as oxygen source. ${ }^{14} \mathrm{CO}_{2}$ produced was trapped in $3 \mathrm{ml} 2 \mathrm{~N} \mathrm{NaOH}$ and analyzed 
with liquid scintillation counting (LSC).

\section{Experimental Results}

Fig 3.5 showed the biodegradation rate of toluene in methanogenic leachate. Data are averages of duplicate samples. The y-axis is the percent of ${ }^{14} \mathrm{CO}_{2}$ recovery based on toluene in aqueous phase at the end of the aging period. Biodegradation of toluene in methanogenic leachate and leachate with HDPE was fast at the initial stage. In solid free leachate, the degradation leveled off after the leachate was exposed to oxygen for twenty hours. The ${ }^{14} \mathrm{CO}_{2}$ recovery was much lower than that in growth medium $(70 \%)$. Samples of the methanogenic leachate at the end of biodegradation were counted by LSC. It was found there were still $2,000 \mathrm{dpm} / \mathrm{ml}{ }^{14} \mathrm{C}$ compounds. The radioactivity did not change after sparging with $\mathrm{N}_{2}$ for two hours, indicating there was no ${ }^{14} \mathrm{C}$ toluene present.

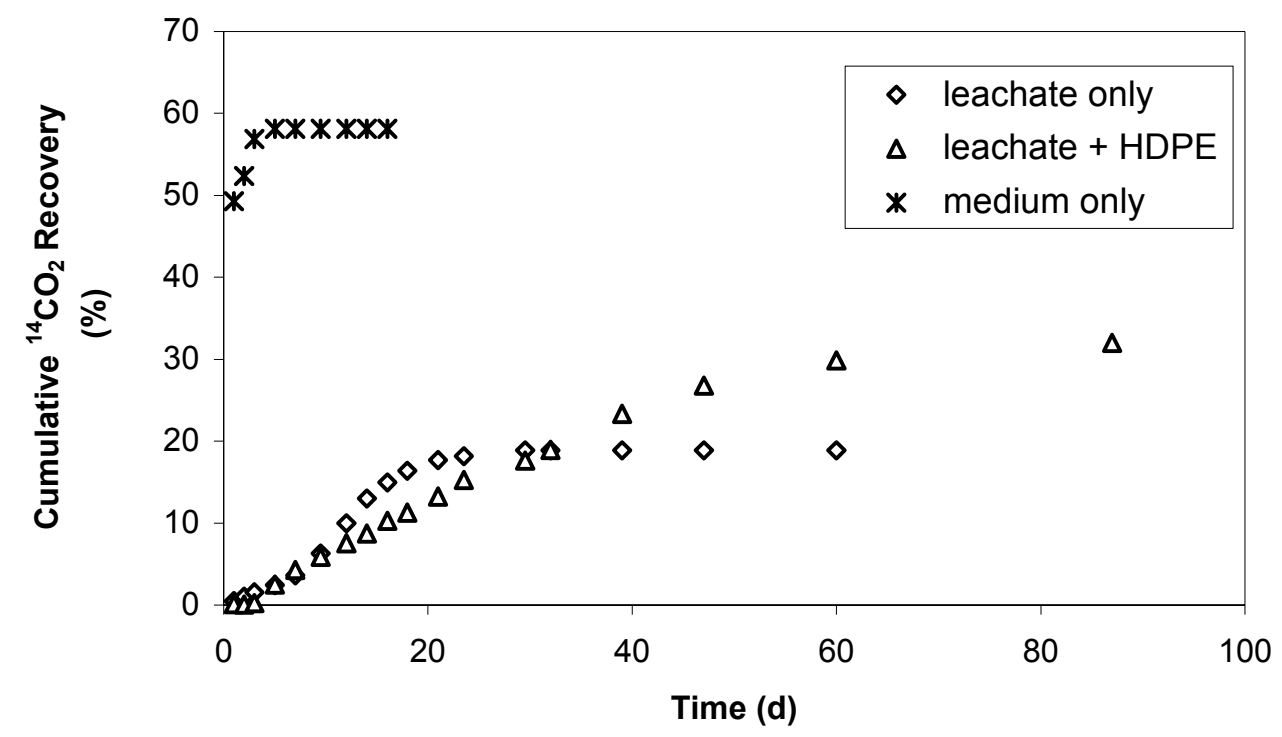

FIGURE 3.5 Bioavailability test conducted in methanogenic leachate.

To analyze the non-bioavailable radioactive compounds in methanogenic leachate, leachate after biodegradation was fractionated by HPSEC (Fig 3.6). Because of the complexity of the aqueous phase, which contained both high-molecular weight substances from methanogenic leachate and intermediates from toluene metabolism, it is not possible to identify the exact substances based 
on the HPSEC analysis. But free toluene was no longer present since no peak showed up at 16 min, the elution time for aqueous toluene.

Several mechanisms can explain this test result. Toluene itself may form strong bonds with higher molecular weight organic matter in methanogenic leachate when oxygen was present. Once toluene was bound, it was no longer bioavailable to the bacteria. The other possibility was some hydroxylated intermediates were produced. The extracellular accumulation of metabolites in aqueous phase may be oxidatively coupled to organic matter in methanogenic leachate and could not be further degraded. Burgos et al. (1996) found similar phenomena when he investigated irreversible binding of naphthalene and $\alpha$-naphthol to soil. Both oxic-autoclaved and anoxic-biotic system did not show irreversible binding. Only in oxic-biotic condition when oxygen and the appropriate extracellular enzymes were present the addition of a hydroxyl group to the aromatic ring made those compounds more reactive with soil organic matter.

Degradation in methanogenic leachate with HDPE kept increasing at lower rate. The presence of solid provided advantage for bacterial growth. In aquatic environments, it is well accepted that bacteria are most often associated with the solid surface. When attached to the solid surfaces, the bacteria were able to consume toluene that diffused out of HDPE before it was exposed and bound to leachate. With sorbed toluene as continuous substrate supply, the degradation continued. Assuming bacteria readily consumed toluene, the concentration gradient between solid phase (HDPE) and bacteria surfaces decreased as toluene continued to diffuse out of HDPE. This explained the gradually decline in degradation rate as time elapsed. 


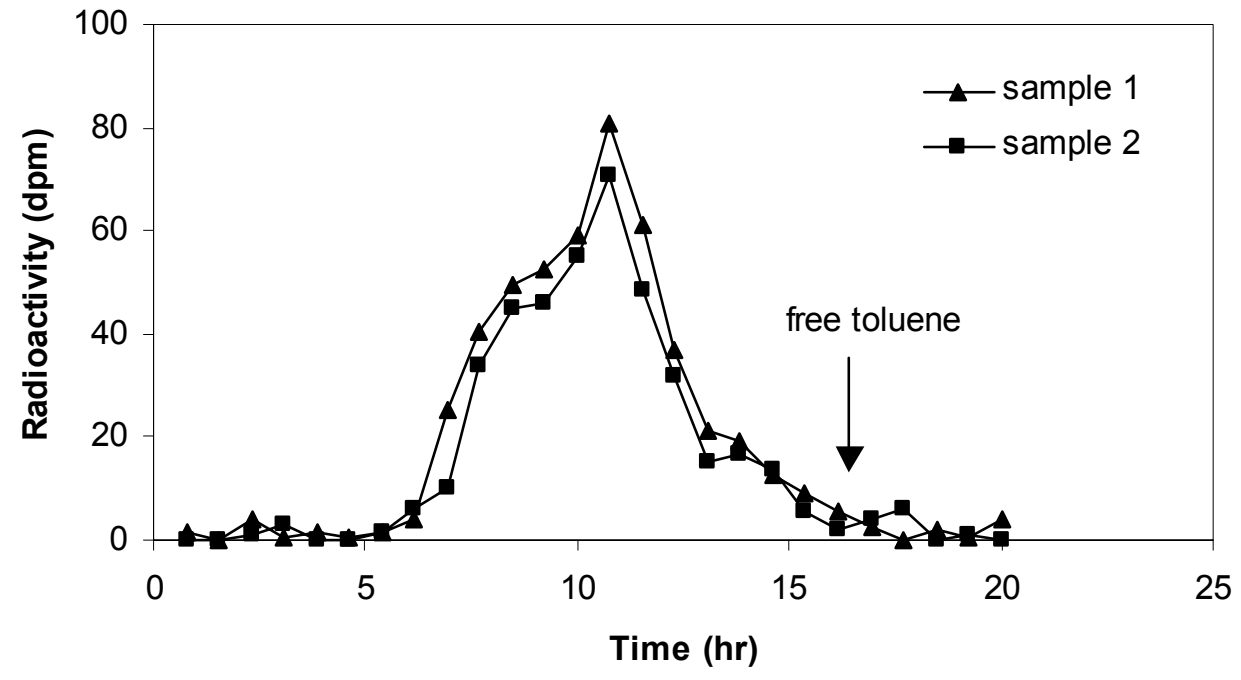

FIGURE 3.6 Analysis of aqueous phase after bioavailability test in methanogenic leachate using HPSEC

Bioavailability tests performed in methanogenic leachate may be complicated because binding of toluene to aqueous-phase organic matter also contributed to the reduction of toluene bioavailability. The extent and rate of binding are determined by factors such as components of leachate and degradation byproducts. The complex nature of the methanogenic leachate and byproducts poses obstacles on differentiation of factors affecting bioavailability. Specifically, it will be difficult to investigate the aging effect on bioavailability of sorbed compounds when other factors are also involved. Moreover, methanogenic leachate exposed to free oxygen is also not an appropriate imitation of municipal landfill leachate. Consequently, bioavailability test will primarily be conducted in growth medium.

\section{Literature Cited}

Burgos, W. D.; Novak, J. T.; Berry, D. F. Reversible sorption and irreversible binding of naphthalene and $\alpha-$ naphthol to soil: elucidation of processes. Environ. Sci. Technol. 1996, 30, 1205-1211.

Chiang, C. Y.; Salanitro, J. P.; Chai, E. Y.; Colthart, J. D.; Klein, C. L. Aerobic biodegradation of benzene, toluene, and xylene in a sandy aquifer-data analysis and computer modeling. Ground Water. 1989, 27, 823-834. 
Christenssen, T. H.; Kjesdsen, P.; Albrechsen, H. J.; Heron, G.; Nielsen, P. H.; Bjerg, P. L.; Holm, P. E. Attenuation of landfill leachate pollutants in aquifers. Crit. Rev. Environ. Sci. Technol. 1994, 24, 119-202.

Edwards, E. A.; Grbic-Galic, D. Anaerobic degradation of toluene and o-xylene by a methanogenic consortium. Appl. Environ. Microbiol. 1994, 60, 313-322.

Pelton, M. T. Effect of aging on the bioavailability of toluene and o-xylene sorbed to municipal solid waste components. Master thesis. North Carolina State University. 2000.

Schumb, W. C. In Hydrogen peroxide. Schumb, W. C.; Satterfield, C. N. and Wentworth, R. L. ed. Reinhold Pub. Corp, New York. 1955.

Shuler, M. L.; Kargi, F. In Bioprocess engineering: basic concepts. Prentice-Hall. New York. 1992.

Wu, B. Y.; Taylor, C. M.; Knappe, D. R. U.; Nanny, M. A.; Barlaz, M. A. Factors controlling alkylbenzene sorption to municipal solid waste. Environ. Sci. Technol. 2001, 35, 4569-4576.

Weiss, J.; Collins, C. H. Radiolysis of aromatic compounds. 1. toluene. T. Am. Nucl. Soc. 1964, 7, 443.

Weiss, J.; Rao, H. M. Radiolysis of aromatic compounds. 3. ethyl toluene. Radiat Res. 1965, 25, 252.

Weiss, J. Collins, C. H. Radiolysis of aromatic compounds-toluene. Radiat Res. 1966, 28, 1 


\title{
Chapter 4
}

\section{Results and Discussion}

This chapter includes two manuscripts and their supporting information to be submitted for publication. Manuscript 1 summarizes the effect of aging on toluene bioavailability and manuscript 2 summarizes the effect of individual biopolymers on toluene bioavailability.

\subsection{The Effect of Aging on the Bioavailability of Toluene Sorbed to Municipal Solid Waste Components}

\begin{abstract}
Landfills are a unique ecosystem that contains priority pollutants and municipal solid waste with $40-60 \%$ organic matter. Interactions of organic contaminants with organic matter in landfills influence their fate and transport. The objective of this study was to evaluate the effects of aging and sorbent decomposition on the bioavailability and fate of toluene sorbed to municipal solid waste (MSW) components. The bioavailability of ${ }^{14} \mathrm{C}$-toluene aged for 1, 30, and 180 days with individual MSW constituents [office paper, newsprint, model food and yard waste, high density polyethylene (HDPE), and poly(vinyl chloride) (PVC)] was evaluated. Anaerobically degraded sorbents were also tested to evaluate the effect of sorbent decomposition. At the termination of bioavailability tests, sequential solvent and alkaline extractions of sorbents and sorbent combustion were performed to measure the partitioning of ${ }^{14} \mathrm{C}$ that was not coverted to ${ }^{14} \mathrm{CO}_{2}$. The bioavailability of toluene sorbed to MSW components was highest in HDPE, a rubbery polymer; followed by the biopolymers and finally PVC, a glassy polymer. Increased toluenesorbent contact time reduced the rate of toluene biodegradation for all MSW components except for HDPE. ${ }^{14} \mathrm{C}$ remaining in sorbents at the completion of bioavailability tests was physically sequestered within and/or covalently bound to sorbent organic matter, and this fraction increased with increasing aging time. Up to $20.2 \%$ of ${ }^{14} \mathrm{C}$ was associated with humic matter (humic and
\end{abstract}


fulvic acids, humin). The increasing hydrophobicity of refuse as it decomposes suggests that the concentrations of hydrophobic organic contaminants in leachate should decrease over time.

\section{Introduction}

Prior to 1976, there were few restrictions on the co-disposal of industrial waste with municipal solid waste (MSW) in landfills, and as late as 1986 there were an estimated 6000 operating municipal landfills plus thousands of closed facilities that likely accepted some hazardous waste (U.S. EPA, 1988). Many of these sites were constructed without an engineered liner or leachate collection system. Unlined landfills have been shown to result in the contamination of both groundwater and surface water (Reinhard et al. 1984; Lesage et al. 1990, Cozzarelli et al. 2000). Nationally, at least $15 \%$ of the sites on the National Priority List of Superfund are municipal landfills that accepted hazardous waste (U.S. EPA, 2003). To protect both ground and surface water resources and design safe and cost-effective remediation strategies, better information on the fate and transport of contaminants in landfills is required.

Alkylbenzenes are among the most frequently detected organic contaminants in landfill leachate (Pohland and Harper 1986; Christenssen et al. 1994). While the biodegradation of toluene has been documented in laboratory-scale systems, its frequent detection in methanogenic leachatecontaminated groundwater suggests that its biodegradation in landfills is incomplete (Sanin et al. 2000). Biodegradation of hydrophobic organic contaminants (HOCs) is affected by HOC interactions with sorbent organic matter (Schwartz and Scow 1999). Residential refuse is rich in organic matter and contains 30-50\% cellulose, 7-12\% hemicellulose, and 15-30\% lignin. Even in well-decomposed refuse with about $70 \%$ of the cellulose and hemicellulose degraded (Ham et al. 1993; Wang et al.; 1994; Mehta et al. 2002), a substantial amount of organic matter remains (Barlaz 1998).

Proposed mechanisms involved in the sequestration of HOCs include adsorption, partitioning, and covalent interactions between metabolites of HOC biodegradation and sorbent organic matter (Hatzinger and Alexander 1995, Dec et al. 1997). For nonionic, recalcitrant compounds, adsorption and partitioning are considered the primary mechanisms for HOC sequestration 
(Weber and Huang 1996). As the sorbent-HOC contact time (or aging time) increases, HOCs become entrapped in structural voids and the hydrophobic interior of sorbent organic matter. Aging is believed to render contaminants increasingly resistant to biodegradation since these microsites are not accessible to the smallest microorganisms and biodegradation is primarily limited by the slow rate of HOC desorption (Nam and Alexander 1998; White et al. 1999). Aging will likely affect long-term contaminant fate and bioavailability in landfills since contaminants are exposed to the buried waste for decades. The metabolites of HOCs biodegradation can also be covalently bound to organic matter through biochemical or abiotic reactions (Bollag et al. 1998). As a result of covalent binding, HOCs become an integral part of the sorbent organic matter and are highly resistant to solvent extraction and microbial biodegradation (Dec and Bollag 1988, Achtnich et al. 1999).

To date, there has been considerable work on the bioavailability of HOCs in soils and sediments, while there has been little work in the high organic carbon environment of a landfill. This study was initiated to determine the fate of HOCs sorbed to MSW and to investigate the effect of aging time and sorbent decomposition on bioavailability. Toluene was chosen as a model compound because of its frequent occurrence in landfill leachate and its biodegradability in landfills (Christensen et al. 1994).

\section{Materials and Methods}

Experimental Design. Bioavailability tests were conducted with the major organic components of MSW in pure form to eliminate the complexity and heterogeneity of mixed refuse. The major components of MSW that are expected to exhibit sorptive capacity include paper, food and yard waste, and plastics. Newsprint and office paper were selected to represent the range of paper types in MSW. Newsprint is a mechanical pulp that contains nearly all of the lignin present in wood while office paper is a chemical pulp from which most of the lignin has been removed. Poly(vinyl chloride) (PVC) and high-density polyethylene (HDPE) were tested to represent glassy and rubbery polymers, respectively. Rabbit food that contained both simple and complex carbohydrates as well as proteins in the form of alfalfa, wheat, soy and oat products was used to 
represent a combination of food and yard waste. The degradable waste components (office paper, newsprint, rabbit food) were tested in both fresh and anaerobically degraded form to evaluate the effect of sorbent decomposition on toluene bioavailability. Bioavailability tests were conducted under aerobic conditions after preliminary work showed that biodegradation rates obtained under anaerobic conditions were too slow to differentiate controls from tests in the presence of sorbent. Bioavailability was measured after aging of the toluene-sorbent system for 1, 30 and 180 days. Fresh rabbit food was only tested after 1 day of aging because it was difficult to sterilize completely and there were problems with gas accumulation during aging. In addition, fresh rabbit food would not be expected to persist in a landfill for extended time periods because it is readily degradable.

MSW components and chemicals. Rabbit food was obtained in $22.8 \mathrm{~kg}$ bags from Manna Pro ${ }^{\circledR}$ Corporation, St. Louis, MO. PVC (42,799-3) and HDPE $(18,958-8)$ were obtained from SigmaAldrich (Milwaukee, WI). Newsprint was collected from The News \& Observer Recycling Division (News \& Observer Publishing Co., Garner, NC). Office paper was collected from the NC State University recycling center. The preparation of degraded sorbents has been described previously (Wu et al. 2001). All sorbents except PVC were dried and ground to pass a $1 \mathrm{~mm}$ screen in a Thomas-Wiley laboratory mill. ${ }^{14} \mathrm{C}$-toluene $(2.8 \mathrm{mCi} / \mathrm{mmol}, 99 \%$ purity $)$ was purchased from Sigma Chemical Co. (St. Louis, MO).

Bioavailability Testing. Prior to aging, sorbents were sterilized in custom-designed ampoules (Fig 4.1) with 2.2 Mrad of $\gamma$-irradiation from a ${ }^{60} \mathrm{Co}$ source. The initial quantity of sorbent sterilized was $2 \mathrm{~g}$ of PVC and fresh rabbit food; $1.5 \mathrm{~g}$ of degraded rabbit food; and $3 \mathrm{~g}$ of HDPE, fresh and degraded office paper, and fresh and degraded newsprint. The quantities of both fresh and degraded rabbit food had to be reduced because of their high oxygen demand while the mass of PVC was lower because of its large sorption capacity. After sterilization, $60 \mathrm{~mL}$ of growth medium and $20 \mu \mathrm{L}$ of stock solution, which contained approximately $1.1 \mu \mathrm{Ci}$ of ${ }^{14} \mathrm{C}$-toluene were added aseptically (only $10 \mu \mathrm{L}$ of stock solution was spiked in fresh office paper samples because of the low sorption capacity). The stock solution was prepared by mixing $1 \mathrm{mCi}$ of ${ }^{14} \mathrm{C}$ - 
toluene with $10 \mathrm{~mL}$ of reagent grade toluene to give a final concentration of $120786 \mathrm{dpm} / \mu \mathrm{L}$. After toluene addition, ampoules were quickly flame sealed to avoid volatilization losses and aged on a shaker table (New Brunswick Innova 2300. Edison, NJ).

After aging, triplicate samples were centrifuged at $3000 \mathrm{rpm}$ for $10 \mathrm{~min}$ (Eppendorf 5810, Brinkmann Instruments Inc., Westbury NY). After breaking the flame sealed ampoule at a score mark, the aqueous phase toluene concentration was measured so that duplicate sorbent-free blanks could be prepared at the same liquid phase concentration as aged samples. In the case of office paper and degraded office paper, blanks were prepared from the supernatant that resulted after the sorbents were aged in HOC-free growth medium. This was necessary because the presence of $\mathrm{CaCO}_{3}$ in the sorbent decreased the phosphate buffer capacity during aging and a $\mathrm{pH}$ increase was observed during biodegradation when $\mathrm{CO}_{2}$ was absorbed in the $\mathrm{NaOH}$ trap. There was a small loss of toluene during the 30 seconds when the ampoule was broken and the stainless steel Swagelok ${ }^{\mathrm{TM}}$ cap was not in place. This loss was quantified by exposing blanks to open air for $30 \mathrm{~s}$ and measuring changes in the toluene concentration. Henry's law was used to calculate the loss of toluene in the gaseous phase. Approximately $13.2 \%$ of the toluene in the aqueous and gas phases was lost, so the amount of toluene added to the sorbent-containing samples was corrected by this amount. Triplicate samples containing sorbent and two sorbent-free blanks were inoculated with $3 \mathrm{~mL}$ of a suspension of Pseudomonas putida F1 (PpFl) to give $1.5 \times 10^{8}$ cells/mL. After inoculation, the bottle was sealed with a Swagelok ${ }^{\mathrm{TM}}$ cap welded with three stainless steel needles (Fig 4.1). Sterile vials were attached to each of the two long needles. One vial contained $2 \mathrm{~mL}$ of $2 \mathrm{~N} \mathrm{NaOH}$ to absorb the evolved ${ }^{14} \mathrm{CO}_{2}$. The second vial contained $1 \mathrm{~mL}$ of $30 \%(\mathrm{v} / \mathrm{v})$ hydrogen peroxide plus $0.5 \mathrm{~mL}$ of $0.5 \%(\mathrm{wt} / \mathrm{wt}) \mathrm{FeCl}_{2}$ as a catalyst to promote $\mathrm{O}_{2}$ production from $\mathrm{H}_{2} \mathrm{O}_{2}$ to maintain aerobic conditions. The $15-\mathrm{cm}$ needles were sealed with push button syringe valves to prevent volatilization losses. A Tedlar gas bag was attached to the 5-cm needle to prevent a pressure increase from excess oxygen. Samples were incubated at $30 \pm 1^{\circ} \mathrm{C}$ in an incubator shaker (New Brunswick Scientific C24 Classic series, Edison, NJ) operating at 140 rpm. ${ }^{14} \mathrm{C}$-toluene biodegradation was quantified by the measurement of ${ }^{14} \mathrm{CO}_{2}$ dissolved in the $\mathrm{NaOH}$ trap which was sampled at $0.2-2$ day intervals. Duplicate $0.5-\mathrm{mL} \mathrm{NaOH}$ aliquots were 
mixed with $6 \mathrm{~mL}$ of Ultima Gold scintillation cocktail (Packard BioScience, Meriden, CT). Prior to scintillation counting, samples were refrigerated overnight to reduce chemiluminescence. Fresh $\mathrm{NaOH}$ was added after each sampling. To assure that the DO level remained above 3 $\mathrm{mg} / \mathrm{L}$, the gas phase oxygen concentration was monitored by a GC equipped with a thermal conductivity detector (Gow Mac Instrument, Bridgewater, NJ). The frequency of $\mathrm{H}_{2} \mathrm{O}_{2}$ replacement was determined by the oxygen demand of individual sorbents as described below.

Bacterial Strains and Growth Conditions. $P p F 1$ was grown at $30 \pm 1^{\circ} \mathrm{C}$ in medium containing $4.2215 \mathrm{~g} \mathrm{KH}_{2} \mathrm{PO}_{4}, 3.368 \mathrm{~g} \mathrm{~K}_{2} \mathrm{HPO}_{4}, 0.05 \mathrm{~g} \mathrm{CaCl}_{2} \cdot 2 \mathrm{H}_{2} \mathrm{O}, 0.005 \mathrm{~g} \mathrm{FeCl}_{3}, 0.201 \mathrm{~g} \mathrm{MgSO} \cdot 7 \mathrm{H}_{2} \mathrm{O}$, $0.5 \mathrm{~g} \mathrm{NH}_{4} \mathrm{NO}_{3}, 0.01 \mathrm{~g}$ disodium EDTA, $1.43 \mathrm{mg} \mathrm{H}_{3} \mathrm{BO}_{3}, 0.32 \mathrm{mg} \mathrm{ZnSO}_{4} \cdot \mathrm{H}_{2} \mathrm{O}, 0.1 \mathrm{mg}$ $\mathrm{CoCl}_{2} \cdot 4 \mathrm{H}_{2} \mathrm{O}, 0.08 \mathrm{mg} \mathrm{CuSO} \cdot \mathrm{H}_{2} \mathrm{O}$ and $0.05 \mathrm{mg} \mathrm{Na} \mathrm{MoO}_{4} \cdot 2 \mathrm{H}_{2} \mathrm{O}$ per liter of deionized water. To prepare an inoculum for a bioavailability test, $25 \mathrm{~mL}$ of sterile medium was inoculated and $P p F 1$ was grown in an incubator shaker $(150 \mathrm{rpm})$ with $0.12 \mathrm{mmol}$ toluene as substrate. After $24 \mathrm{hr}$, $0.5 \mathrm{~mL}$ of the culture was transferred into $25 \mathrm{~mL}$ of fresh medium. $0.12 \mathrm{mmol}$ toluene was added as substrate and the culture was incubated for an additional $24 \mathrm{hr}$. The cells were then washed twice with $50 \mathrm{mM}$ pH 7 phosphate buffer and resuspended to an optical density of 0.79 at $600 \mathrm{~nm}$.

Sorbent Mineralization. The oxygen demand of the sorbents was evaluated in preliminary work to ensure that bioavailability tests could be maintained under aerobic conditions. Three gm of $\gamma$ irradiated biopolymer sorbents were mixed with $100 \mathrm{~mL}$ of sterile growth medium in sterile 250 $\mathrm{mL}$ Erlenmeyer flasks sealed with rubber stoppers. $P p F 1$ was inoculated and samples were incubated at $30 \pm 1^{\circ} \mathrm{C}$ in an incubator shaker with hydrogen peroxide as the oxygen supply. Evolved $\mathrm{CO}_{2}$ was trapped in $20 \mathrm{~mL}$ carbonate free $\mathrm{NaOH}$. Periodically, the $\mathrm{NaOH}$ trap was replaced and inorganic carbon was analyzed by a Shimadzu TOC 5000A analyzer (Columbia, MD). The dissolved oxygen concentration in the flask was checked daily using Chemets selffilling DO ampoules (Chemetrics Inc. Calverton, VA). Background $\mathrm{CO}_{2}$ was measured in an uninoculated flask containing sterile fresh rabbit food. 
Measurement of ${ }^{14} \mathrm{C}$ distribution after bioavailability testing. A series of analyses and extractions were conducted to measure the fate of the added ${ }^{14} \mathrm{C}$-toluene that was not recovered as ${ }^{14} \mathrm{CO}_{2}$. At the completion of a bioavailability test, the sorbent-medium mixture was centrifuged in a 50-mL Teflon ${ }^{\mathrm{TM}}$ screw cap centrifuge tube at $3000 \mathrm{rpm}$ for 10 min after which the presence of ${ }^{14} \mathrm{C}$ in the supernatant was measured both before and after filtration through a 0.2 $\mu \mathrm{m}$ cellulose acetate syringe filter (VWR, Atlanta, GA). Preliminary tests showed that there was no significant difference in ${ }^{14} \mathrm{C}$ concentration between direct injection of unfiltered aqueous sample to scintillation cocktail and injection of samples after cell lysis by lysozyme (Table A.1). The difference between filtered and unfiltered samples is ${ }^{14} \mathrm{C}$ associated with particulate matter and biomass. Next, benzyl alcohol (BA) was used to extract sorbed ${ }^{14} \mathrm{C}$. The sorbent was exposed to 20-25 mL of BA for $200 \mathrm{hr}$ after which the mixture was centrifuged at $3000 \mathrm{rpm}$ for 10 min. Duplicate samples were then removed for scintillation counting. The BA extraction was repeated until less than $0.05 \%$ of the total counts added were recovered from the solid. To complete the BA extraction step, the solvent extracted sorbents were washed with deionized water until a separate solvent phase was no longer observed. All BA extracts were combined to report the content of BA extractable ${ }^{14} \mathrm{C}$. To study the association of ${ }^{14} \mathrm{C}$-labeled contaminant with humic substances, solvent extracted sorbents were subjected to a series of $\mathrm{NaOH}$ extractions. Sorbents were shaken for $200 \mathrm{hr}$ in 20-25 mL 0.1 N NaOH. The sorbent-base mixture was then centrifuged at $3000 \mathrm{rpm}$ for 10 min to obtain a sample of supernatant for scintillation counting. The $\mathrm{NaOH}$ extraction was repeated until less than $0.05 \%$ of the total counts added were recovered from the solid. All $\mathrm{NaOH}$ extracts were combined to report the content of $\mathrm{NaOH}$ extractable ${ }^{14} \mathrm{C}$.

Humic acid (HA) was obtained by acidifying the $\mathrm{NaOH}$ extracts to $\mathrm{pH} 1.5$ with $6 \mathrm{~N} \mathrm{HCl}$ and precipitating for $24 \mathrm{hr}$ at $4^{\circ} \mathrm{C}$. The precipitate was collected by centrifugation and then dissolved in $0.1 \mathrm{~N} \mathrm{NaOH}$ prior to scintillation counting and TOC analysis (Shimadzu TOC 5000A analyzer, Columbia, MD). The supernatant from the $\mathrm{pH} 1.5$ acidification was passed through a 54-mL glass column packed with $50 \mathrm{~mL}$ DAX8 ${ }^{\mathrm{TM}}$ resin $\left(\mathrm{k}^{\prime}{ }_{0.5 \mathrm{r}}=5\right)$ at a flow rate of $12.5 \mathrm{~mL} / \mathrm{min}$. Fulvic acid (FA), which was retained on the resin, was eluted with $0.1 \mathrm{~N} \mathrm{NaOH}$ at $1.5 \mathrm{~mL} / \mathrm{min}$ 
by a peristaltic pump. Nonsorbed effluent was classified as non-humic substances (NH). Both FA and NH fractions were collected for scintillation counting and TOC analysis.

The ${ }^{14} \mathrm{C}$ contained in HA, FA and $\mathrm{NH}$ fractions was further characterized by high performance size exclusion chromatography (HPSEC). A Protein Pak 125 column (Waters, Milford, MA) was used in a high performance liquid chromatography (HPLC) system equipped with a UV detector and a Foxy Jr. fraction collector (Isco Inc., Lincoln, Nebraska). The injection volume was $250 \mu 1$ and detection was performed at $254 \mathrm{~nm}$. The mobile phase was $20 \mathrm{mM} \mathrm{pH} 7$ phosphate buffer $\left(\mathrm{NaH}_{2} \mathrm{PO}_{4} / \mathrm{Na}_{2} \mathrm{HPO}_{4}\right)$ with its ionic strength adjusted to 0.1 with $\mathrm{NaCl}$. The eluent flow rate was $1 \mathrm{~mL} / \mathrm{min}$. Polystyrene sulfonates of molecular weights from 1.8 to $100 \mathrm{kDa}$ were used as standards. The inner volume of the column was determined using $0.5 \%$ acetone. The dead volume was determined with a $0.1 \%$ blue dextran solution.

${ }^{14} \mathrm{C}$ that was not extracted from the sorbent was combusted in a Linderberg/Blue tube furnace (Asheville, NC) at $875^{\circ} \mathrm{C}$. The exhaust gas was routed to a Barnstead/Thermolyne tube furnace (Dubuque, Iowa) to ensure complete combustion. ${ }^{14} \mathrm{CO}_{2}$ produced was trapped in four successive $\mathrm{NaOH}$ traps $(15 \mathrm{~mL}, 2 \mathrm{~N})$ and analyzed by scintillation counting.

Data Analysis. The extent of mineralization of sorbed toluene was calculated from eqn. 1.

Extent of mineralization $(\%)=\frac{P_{\text {sorbent }}-P_{\text {blank }}}{q} \times 100$

Where $P_{\text {sorbent }}$ and $P_{\text {blank }}$ represent ${ }^{14} \mathrm{CO}_{2}(\mathrm{dpm})$ production from samples containing sorbents and sorbent-free blanks that had the same aqueous-phase toluene concentration as the sorbentcontaining samples after aging, and $q(\mathrm{dpm})$ corresponds to the mass of toluene present in a sorbent after aging. Thus, the extent of mineralization at the end of the bioavailability test was calculated based on the conversion of sorbed toluene to ${ }^{14} \mathrm{CO}_{2}$.

The extent of mineralization and the distribution of ${ }^{14} \mathrm{C}$ residue in sorbents after bioavailability tests were compared by an analysis of variance. If the F-statistic from the analysis of variance showed a significant difference $(\mathrm{p}<0.05)$, then the pairwise comparison test was used to 
determine which samples were different. All statistical analyses were performed by SAS 8.0 software (SAS Institute Inc., Cary, NC).

\section{Results}

Sorbent Biodegradation. The fraction of each sorbent degraded by $P p F 1$ and the maximum oxygen demand are presented in Table 4.1. Mineralization of both fresh and anaerobically degraded office paper and newsprint was below $2 \%$. Based on the size of the inoculum $\left(9 \times 10^{9}\right.$ cells), a cell mass of $1 \times 10^{-12} \mathrm{~g}$ (Brock and Madigan 1991), a cell composition of $\mathrm{C}_{5} \mathrm{H}_{7} \mathrm{O}_{2} \mathrm{~N}$ and the decay of $20 \%$ of the inoculum, this amount of $\mathrm{CO}_{2}$ can be attributed to biomass decay, indicating that PpFl could not hydrolyze much if any lignocellulose. However, the fresh and degraded rabbit food underwent significant mineralization. Rabbit food contained protein and carbohydrates and Pseudomonads are known to produce highly active proteolytic enzymes (Pelczar Jr. and Reid 1958).

To calculate the oxygen demand of each sorbent, the biodegradable carbon content in each sorbent was conservatively assumed to be in its most reduced form. The calculation resulted in the maximum possible oxygen demand (Table 4.1). For rabbit food and degraded rabbit food, frequent replacement of $\mathrm{H}_{2} \mathrm{O}_{2}$ in the initial $72 \mathrm{hr}$ of a bioavailability test was required to maintain aerobic conditions. During bioavailability testing, regular measurement of the gas phase by GC showed that the oxygen concentration was $25-40 \%$, which indicated oxygen was not a limiting factor in toluene biodegradation.

Toluene Bioavailability and the Effect of Sorbent Properties. Mineralization curves for the 1day aging tests are presented in Fig 4.2 and mineralization curves at other aging times are presented in the Supporting Information (Figs S4.1 and S4.2). One-day aging bioavailability tests were terminated when daily ${ }^{14} \mathrm{CO}_{2}$ production was less than $0.5 \%$ of the initially added toluene. Tests were terminated at the same time for all aging periods so that results could be compared. Biodegradation of toluene sorbed to MSW components was bimodal in that it occurred in a fast stage followed by a slow stage. To confirm that the decline in the biodegradation rate was 
attributable to substrate availability and not to a loss of microbial activity during prolonged incubation, two samples for each sorbent were reinoculated with $\mathrm{PpFl}$ after ${ }^{14} \mathrm{CO}_{2}$ production ceased. Reinoculation did not stimulate biodegradation, as evidenced by the insignificant difference between samples with and without freshly added PpF1 ( $\mathrm{p}>0.93$; Fig A.1). Selected samples that were not reinoculated were sacrificed by adding additional ${ }^{14} \mathrm{C}$-toluene once biodegradation ceased. In all cases, there was a dramatic increase in ${ }^{14} \mathrm{CO}_{2}$ production (Fig A.1), indicating that $\mathrm{PpFl}$ retained its degradation ability for the duration of bioavailability test.

The mineralization rates observed for toluene sorbed to homogeneous polymers, HDPE and PVC, represent the two extremes in terms of toluene bioavailability (Fig 4.2). Among the tested sorbents, the mineralization rate of toluene in contact with HDPE was the highest. In contrast, the slowest mineralization rate was observed for toluene sorbed to PVC. Blanks without PVC showed a higher initial ${ }^{14} \mathrm{CO}_{2}$ production rate than samples containing PVC, as indicated by the negative portion of the mineralization curve for the first $20 \mathrm{hrs}$. This result can be explained on the basis that toluene had not reached a sorption equilibrium with PVC after 1 day of aging. [About 250 days were required to reach sorption equilibrium with PVC (Wu et al. 2001)]. The continued uptake of toluene by PVC following inoculation likely decreased the liquid phase substrate concentration relative to the blank, resulting in lower ${ }^{14} \mathrm{CO}_{2}$ production rates in samples containing PVC. Initial negative sections of the mineralization curve were not detected after 30 days and 180 days of aging as uptake of toluene by PVC was closer to equilibrium (Figs S4.1 and S4.2 in the Supporting Information).

The mineralization curves for toluene sorbed to biopolymers fell between HDPE and PVC (Fig 4.2). Biopolymer composites are heterogeneous complexes that include cellulose, hemicellulose, lignin, proteins and lipids. The negative portion of the mineralization curve for toluene sorbed to fresh rabbit food in the first $48 \mathrm{hr}$ was likely a result of the preferential biodegradation of rabbit food over toluene (Fig 4.2).

Effect of Aging on Toluene Bioavailability. The percentage of sorbed toluene that was mineralized after aging times of 1,30 and 180 days is presented in Table 4.2 (at $200 \mathrm{hrs}$ of 
incubation) and Table 4.3 (at termination of a bioavailability test). In general, the extent of mineralization decreased as the aging time increased. For fresh and degraded rabbit food, fresh and degraded newsprint and PVC, the aging effect was most significant in the first 30 days. HDPE was the exception to this statement as no statistically significant aging effect was observed $(\mathrm{p}>0.83)$.

Several processes contributed to the decrease in toluene bioavailability in office paper and degraded office paper. In addition to aging, a $\mathrm{pH}$ change was detected during biodegradation despite the presence of $50 \mathrm{mM}$ phosphate buffer (Table 4.4). During aging, $\mathrm{Ca}^{2+}$ released from $\mathrm{CaCO}_{3}$ in office paper likely produced a number of calcium phosphate precipitates such as calcium hydrogen phosphate $\left(\mathrm{CaHPO}_{4}\right)$, calcium dihydrogen phosphate $\left(\mathrm{Ca}\left(\mathrm{H}_{2} \mathrm{PO}_{4}\right)_{2}\right)$, hydroxyapatite $\left(\mathrm{Ca}_{5}\left(\mathrm{PO}_{4}\right)_{3} \mathrm{OH}\right)$, and $\beta$-tricalcium phosphate $\left(\beta-\mathrm{Ca}_{3}\left(\mathrm{PO}_{4}\right)_{2}\right)$ (Snoeyink and Jenkins 1980), therefore decreasing phosphate buffer capacity. This precipitation process is slow (Snoeyink and Jenkins 1980), and the loss of buffer capacity increased with increasing aging time. The total phosphate concentration decreased from $3.2 \mathrm{~g} / \mathrm{L}$ in fresh medium to $2.9 \mathrm{~g} / \mathrm{L}$ and $1.8 \mathrm{~g} / \mathrm{L}$ after 1-d and 180-day aging, respectively. The introduction of a $\mathrm{NaOH}$ trap in the biodegradation test provided a sink for $\mathrm{CO}_{2}$, which stimulated $\mathrm{CaCO}_{3}$ dissolution and caused a $\mathrm{pH}$ increase. Additional tests confirmed that $\mathrm{PpFl}$ was inhibited at $\mathrm{pH} 9$ relative to $\mathrm{pH} 7$ (Fig S4.4 in Supporting Information). Thus the $\mathrm{pH}$ change likely increased the aging effect as the $\mathrm{pH}$ increase inhibited the rate of toluene mineralization.

Distribution of ${ }^{14} \mathrm{C}$-Toluene at the Completion of Bioavailability Tests. The distribution of ${ }^{14} \mathrm{C}$-activity in the sorbents upon completion of bioavailability tests is presented in Table 4.5. The total recovery of added ${ }^{14} \mathrm{C}$-toluene (88.1-101.3\%) demonstrated that the experimental setup was suitable for evaluating the bioavailability of a volatile contaminant. The benzyl alcohol extraction recovered all remaining toluene in HDPE and PVC, which was expected because toluene uptake by these plastics is a result of partitioning (HDPE) or a combination of partitioning and adsorption (PVC). The quantity of ${ }^{14} \mathrm{C}$ extracted from HDPE was relatively constant for the three aging times. In contrast, $17 \%$ more ${ }^{14} \mathrm{C}$ was extracted from $\mathrm{PVC}$ when the aging time increased from 1 to 30 days $(\mathrm{p}<0.001)$ and an additional increase was measured 
between 30 and 180 days $(\mathrm{p}<0.001)$. This increase in solvent extractable ${ }^{14} \mathrm{C}$ with aging time mirrors the findings of toluene bioavailability. More toluene diffused into the physically remote sites of PVC as the aging time increased. Consequently, more time was required for the toluene molecules to diffuse out of the sorbent and become bioavailable to microorganisms.

Biopolymer sorbents contain humic substances and toluene associated with humic matter would not be extracted with BA. To determine the change in the distribution of non-bioavailable ${ }^{14} \mathrm{C}$, BA extractable ${ }^{14} \mathrm{C}$ was normalized based on the total ${ }^{14} \mathrm{C}$ that remained in the sorbents after bioavailability testing (Table 4.6). The BA extractable ${ }^{14} \mathrm{C}$ from all biopolymers decreased with increasing aging time, indicating the transformation of the remaining ${ }^{14} \mathrm{C}$ from a labile to a more strongly bound fraction.

${ }^{14} \mathrm{C}$ Association with Humic Substances. ${ }^{14} \mathrm{C}$ that remained after extraction with BA was extracted with $\mathrm{NaOH}$ and classified as $\mathrm{HA}, \mathrm{FA}, \mathrm{NH}$ and humin based on operational definitions (Thurman and Malcolm 1981). HA is defined by its solubility in dilute alkaline solutions and by precipite formation at $\mathrm{pH}<2$, while FA is defined by its solubility in acids and bases. Following precipitation of $\mathrm{HA}$, the FA and $\mathrm{NH}$ fractions were separated using a DAX8 ${ }^{\mathrm{TM}}$ resin. $\mathrm{NH}$ substances were not retained by the DAX8 ${ }^{\mathrm{TM}}$ resin and are likely comprised amino acids and organic acids synthesized by living organisms (Stevenson 1994). Humin is humic matter that is insoluble in dilute acids and bases. Radioactivity was detected in all humic fractions except for HA fractions in fresh and degraded office paper (1, 30 and 180-day aging) and the FA and NH fractions in fresh office paper (1-day aging) (Table 4.5).

To determine the molecular weight fraction that contains ${ }^{14} \mathrm{C}, \mathrm{HA}, \mathrm{NH}$ and FA extracted from MSW sorbents were fractionated by HPSEC. A typical chromatogram illustrating HA extracted from rabbit food is shown in Fig 4.3. The retention time of toluene was determined by monitoring the absorbance of a sample containing toluene only. The HPSEC results indicate that the ${ }^{14} \mathrm{C}$ in the HA fraction extracted from rabbit food was associated with organic matter with a molecular size greater than toluene. Chromatograms of HA, FA, and $\mathrm{NH}$ fractions extracted from other sorbents all indicated the presence of ${ }^{14} \mathrm{C}$ in relatively high molecular weight fractions (Fig 
$\mathrm{S} 4.3$ in Supporting Information). Furthermore, the absence of free toluene suggests that ${ }^{14} \mathrm{C}$ in $\mathrm{NaOH}$ extractable fractions existed only in a bound form (either toluene was strongly associated with the organic matter or toluene metabolites were covalently bound to the organic matter).

The FA fraction accounted for 76-99\% of the non-purgable organic carbon (NPOC) in $\mathrm{NaOH}$ extract (Table 4.7). However, HA retained 3.7-24.3 times more ${ }^{14} \mathrm{C}$ than FA when normalized for organic carbon (Table 4.8). Similarly, the NH fraction, which likely contains biochemical compounds synthesized by microorganisms, contained 8.1-25.9 times more ${ }^{14} \mathrm{C}$ than FA.

With the exception of fresh office paper, the percentage of ${ }^{14} \mathrm{C}$ in the humin fraction increased with aging time (Table 4.9), further illustrating the importance of aging on toluene sequestration.

\section{Discussion}

Synthetic Polymers. HDPE and PVC are synthetic polymers that consist of repeating ethylene and vinyl chloride monomers, respectively. HDPE and PVC behaved differently with respect to sorption and bioavailability. The different behavior can be attributed to the dissimilarities in their polymeric structures and particle size. At the temperature at which the bioavailability tests were conducted, HDPE is a rubbery polymer while PVC is a glassy polymer. Rubbery polymers have an expanded, flexible structure while glassy polymers have a more rigid, condensed structure (Xing et al. 1996). Both rubbery and glassy polymers contain regions into which HOCs can partition. In addition, glassy polymers contain hole sites, where HOCs can adsorb. HOC diffusion through glassy polymers are lower than through rubbery polymers because the glassy polymer structure is more rigid and because adsorption energies of hole sites are large (Weber et al. 1992). Abiotic desorption tests showed that up to $99 \%$ of the sorbed toluene was released from HDPE within 70 hours. However, toluene sorbed to PVC was released more slowly and only $33 \%$ was released within the same time period. Diffusion of toluene through homogeneous polymers can be described by Fick's second law of diffusion, which dictates that the desorption rate of toluene is positively related to the diffusion coefficient and inversely related to the square of particle diameter. The diameter of $\operatorname{HDPE}(500 \mu \mathrm{m})$ was about 3.6 times larger than that of PVC $(140 \mu \mathrm{m})$ while the diffusion coefficient of toluene in HDPE $\left(\sim 10^{-9} \mathrm{~cm}^{2} / \mathrm{s}\right)$ (Rogers et al. 
1960) is several orders of magnitude larger than in PVC $\left(10^{-13}-10^{-14} \mathrm{~cm}^{2} / \mathrm{s}\right)$ (Berens 1989). Consequently, the more rapid degradation of toluene sorbed to HDPE can be explained by the more rapid release of toluene from HDPE particles. As the aging time increased, toluene molecules diffused further into the rigid organic matter and hole sites of PVC. Therefore, the diffusion path length increased as aging time increased, which explains why toluene release rates and thus ${ }^{14} \mathrm{CO}_{2}$ production decreased with increasing aging time on PVC. In HDPE, however, toluene was present only in expanded dissolution sites, from which desorption rates are fast. Therefore, the toluene release rate from HDPE was not significantly affected by toluene-sorbent contact time. The ${ }^{14} \mathrm{C}$ that remained in HDPE and PVC after bioavailability test was readily extractable by BA. The relatively constant ${ }^{14} \mathrm{C}$ in BA extracts of HDPE with aging and the timedependent increase of ${ }^{14} \mathrm{C}$ in BA extracts of PVC are consistent with the finding that increased aging time significantly reduced the bioavailability of toluene sorbed to PVC while no effect was observed with HDPE (Table 4.2).

Biopolymers. The mineralization rate of toluene sorbed to both fresh and degraded biopolymers fell between those for the two synthetic polymers (Fig 4.2). This could be attributed to the lower sorption capacity of biopolymers for toluene than that of HDPE and consequently less mass of substrate released from biopolymers. In addition, preferential degradation of organic matter in biopolymers, e.g. fresh rabbit food may also decrease the biodegradation rate of sorbed toluene. Because of presence of rapid desorption fraction, biodegradation rate of toluene sorbed to biopolymers is faster than that to PVC.

The extent of mineralization followed the similar trend in the initial $200 \mathrm{hrs}$ of incubation. However, this may not be true if the incubation time is extended. Despite the slow release rate, toluene sorbed to synthetic polymers would be completely available to microorganisms after sufficient incubation because of the absence of humic substances. For biopolymers, complete mineralization of the sorbed toluene is not expected because of the association of ${ }^{14} \mathrm{C}$ with humic substances and the poor biodegradability of bound ${ }^{14} \mathrm{C}$.

Relative to the 1-d aging time, the bioavailability of toluene sorbed to biopolymers was reduced 
by $11-22 \%$ and $12-29 \%$ after 30 and 180 days of aging, respectively. The aging effect can be explained by the continued diffusion of toluene molecules into condensed organic matter and the formation of stronger associations between ${ }^{14} \mathrm{C}$ and sorbent organic matter. These results were also confirmed by abiotic desorption data, which showed a decrease in the fast desorbing fraction and an increase of slow desorbing fraction with increasing aging time (Wu 2002). Although the bioavailability of toluene sorbed to fresh and degraded office paper appeared to decrease with increasing aging time, this result was at least in part a result of a $\mathrm{pH}$ increase that occurred during the biodegradation step, and this $\mathrm{pH}$ increase decreased the rate of toluene mineralization. As explained above, the magnitude of the $\mathrm{pH}$ rise increased as the aging time became longer (Table 4.4). Furthermore, ingredients in fresh office paper may have had an inhibitory effect on PpF1 (Fig S4.5 in Supporting Information). To fully understand this issue, additional studies are needed to quantify the effect of the chemicals involved.

The percentage of solvent extractable radioactivity based on total sorbent-retained radioactivity decreased with increasing aging time. Although it is suggested that HOCs sequestered in remote microsites of organic matter can be removed by solvent extraction (Wershaw 1993; Dec et al. 1997), the definition of solvent extractable residue is not as clear as suggested by the terminology. For example, Dec et al. (1997) suggested that the fraction of ${ }^{14} \mathrm{C}$ that cannot be solvent extracted is sorbed to humin fraction without being chemically modified. Guthrie et al. (1999) reported that pyrene that is bound to the humin fraction by van der Waals forces and hydrogen bonding could not be removed by stringent solvent extraction methods. Similarly, using solvent extraction to predict bioavailability of HOCs is a poorly defined process since it is strongly affected by the species of sorbate, type of sorbent and solvent, and extraction techniques (Alexander 2000; Reddy et al. 2000; Tang et al. 2002, Johnson et al. 2002). An organic solvent such as BA could swell the sorbent organic matrix and open diffusive pathways in those regions of the sorbent organic matter from which alkylbenzene partially desorbed. Also, ${ }^{14} \mathrm{C}$ associated with lipophilic extractives could also be extracted when lipophilic extractives dissolve in BA. However, it is not clear that the BA extractable fraction represents the ultimate toluene bioavailability. 
The presence of ${ }^{14} \mathrm{C}$ in the humic substances of biopolymers was not surprising as humic substances are formed by the chemical and biological transformation of lignocellulosic materials (Wershaw 1993). Both the precursors, lignin in particular, and humic substances contain reactive functional groups that can act as binding sites for HOCs (Stevenson 1994). The type of association between pollutants and humic substances could include ester bonds formed by condensation reactions (Richnow et al. 1993, Käcker et al. 2002) as well as ether and carboncarbon bonds formed by enzyme-mediated oxidative polymerization (Richnow et al. 1997). Similar transformations were also expected for toluene because microbial degradation of toluene results in hydroxylated aromatic compounds that are chemically more reactive than the parent compound. These compounds have been detected in growth medium (Dagley et al. 1964, Gibson et al. 1968, Yu et al. 2001). Metabolites such as cis,cis-2-hydroxy-6-oxohepta-2,4-dienoate and 4-hydroxy-2-oxo-valerate bear carboxylic groups which may be capable of forming ester bonds with humic substances. Aromatic alcohols such as 3-methylcatechol were suggested to bind to humic substances through enzymatic cross-coupling (Richnow et al. 1997).

Treatment of biopolymers with $\mathrm{NaOH}$ causes the disruption of H-bonding in cellulose and hemicellulose, breakage of ester linkages, and deprotonation of acidic carboxylic and phenolic groups (Akin et al. 1992, Simpson et al. 2003). As a result, swelling of cellulose and the partial solubilization of protein, hemicellulose and lignin are expected (Jackson 1977, Scalbert and Monties 1986, Tomotake et al. 2002). In the case of office paper, sizing agents such as alkenyl succinic anhydrides (ASA) and alkyl ketene dimers (AKD) are bound to cellulose through a $\beta$ keto ester linkage and would be released during $\mathrm{NaOH}$ treatment (ASA and AKD are neutral $\mathrm{pH}$ sizing agents which are applied to paper with large $\mathrm{CaCO}_{3}$ usage) (Roberts 1996). This is a likely explanation for the presence of ${ }^{14} \mathrm{C}$ in the $\mathrm{NaOH}$ extract of fresh and degraded office paper. In the case of fresh rabbit food, the ${ }^{14} \mathrm{C}$ in humic substances was primarily attributed to the partial dissolution of lignin and/or ${ }^{14} \mathrm{C}$ that was covalently linked to lignin. Alkali dissolved lignin has a higher degree of polymerization and it may also contain co-extracted polysaccharides, which explains the association of ${ }^{14} \mathrm{C}$ with substances of large molecular weight (Fig 4.3, Fig S4.3 in Supporting Information) (Xiao et al. 2001, Durot et al. 2003). In fresh newsprint, besides lignin, $\mathrm{NaOH}$ could also remove some wood extractives like phenolic acids (Akin et al. 1992, Martens 
2000). Phenolic acids such as ferulic acid and syringaldehyde were reported to be very reactive during oxidative coupling reactions where covalent bonds are formed between metabolites of organic compounds and humic substances.

Compared to $\mathrm{NaOH}$ extracts of fresh biopolymers, the $\mathrm{NaOH}$ extract of degraded biopolymers contains both fresh and humified lignocelluloses. Except for humic acids extracted from degraded office paper, ${ }^{14} \mathrm{C}$ activity was detected in all fractions of humic matter. The lack of humic acids in degraded office paper may be attributed to its extremely lower lignin content as humic acids are proposed to result from the condensation of modified lignin with protein (Bollag et al. 1998). Humic acids are rich in phenolic groups (Weber et al. 2000), compared to which fulvic acids are lower in aromaticity because fulvic acids possess a significant concentration of oxygen-containing carboxyl and alcohol functional groups (Hatcher and Spiker 1983, Aochi and Farmer 1997). Because of their higher polarity and lower aromaticity, fulvic acids bound less ${ }^{14} \mathrm{C}$-toluene than humic acids (Table 4.8).

Except for fresh office paper, the combustion data showed that ${ }^{14} \mathrm{C}$ associated with the humin fraction of biopolymer composites increased with aging. The humin structure is dominated by undegraded and slightly degraded biopolymers, such as lignin and polysaccharides (Hatcher et al. 1985). Humin is believed to represent the glassy domain of organic matter because it has a more condensed structure than humic acids which may restrict the diffusion of HOCs and it appears to be enriched in subnanometer-size voids that might provide specific sorption sites for organic compounds (White et al. 1999, de Jonge et al. 2000). During aging, more toluene molecules were trapped in humin through the combination of diffusion into micropores and partition into organic matter, resulting in enrichment of radioactivity over time.

Environmental Significance. Although bioavailability tests were conducted under aerobic condition, the test results can be extended to the landfill ecosystem, which is anaerobic. Because microorganisms are size-excluded from a sorbent matrix, it is generally believed that all biodegradation occurrs in the dissolved phase (Ogram et al. 1985; Johnson et al. 1999) and bioavailability is controlled by the rate of contaminants desorption (Rockne et al. 2002). 
Although the biodegradability of soil-sorbed compounds has been reported (Racke and Lichtenstein 1985; Guerin and Boyd 1997), no direct evidence was presented to indicate that sorbed compounds were degraded without being released to the aqueous phase or sorbent surface.

Estimating the change of HOC concentrations in landfill leachate over time is difficult because the increase of sorbent hydrophobicity is counterbalanced by the loss of sorbent organic matter. Reinhart et al. (1990) reported that the increases in sorbent hydrophobicity as a result of biopolymer degradation had little effect on $\mathrm{K}_{\mathrm{oc}}$ for sorption of HOCs to relatively nonpolar refuse, suggesting that landfill leachate $\mathrm{HOC}$ concentrations would increase over time due to the loss of sorbent organic matter. For a landfill where paper waste dominates, however, given the fact that the preferentially decomposed cellulose and hemicellulose have poor sorptive capacity for HOCs and the resynthesized lipids and proteins have higher affinity for HOCs, it would suggest that HOC concentrations in leachate should decrease with time.

\section{Acknowledgments}

Although the research described in this article was funded by the U.S. EPA, it has not been subjected to the Agency's peer and administrative review and therefore may not necessarily reflect the views of the Agency; no official endorsement should be inferred. We thank Dr. Mike Hyman in the Department of Microbiology for providing toluene-degrading bacteria, experimental facilities and much constructive advice; Mr. Jerry Wicks in the Department of Nuclear Engineering for sterilization of our samples; Dr. Wayne Robarge in the Department of Soil Science for technical support and Dr. Hou Min Chang in the Department of Wood and Paper Science for many helpful discussions.

\section{Literature Cited}

(1) US EPA National survey of solid waste (municipal) landfill facilities. EPA/530-SW88-034. Office of Solid Waste and Emergency Response, 1988, US Environmental Protection Agency, Washington, D.C.

(2) Reinhard, M.; Goodman, N. L.; Barker, J. F. Occurrence and distribution of organic chemicals in two landfill 
leachate plumes. Environ. Sci. Technol. 1984, 18, 953-961.

(3) Lesage, S.; Jackson, R. E.; Priddle, M. W.; Riemann, P. G. Occurrence and fate of organic solvent residues in anoxic groundwater at the Gloucester landfill, Canada. Environ. Sci. Technol. 1990, 24, 559-566.

(4) Cozzarelli, J. M.; Suflita, J. M.; Ulrich, G. A.; Harris, S. H.; Scholl, M. A.; Schlottmann, J. L.; Christenson, S. Geochemical and microbiological methods for evaluating anaerobic processes in an aquifer contaminated by landfill leachate. Environ. Sci. Technol. 2000, 34, 4025-4033.

(5) US EPA (2003) http://www.epa.gov/superfund/sites/query/queryhtm/nplfin1.htm accessed Mar. 2003.

(6) Pohland, F. G.; Harper, S. A. Critical review and summary of leachate and gas production from landfills. U.S. EPA Report, 1986, EPA/600/2-86/073, Washington, D.C.

(7) Christenssen, T. H.; Kjesdsen, P.; Albrechsen, H. J.; Heron, G.; Nielsen, P. H.; Bjerg, P. L.; Holm, P. E. Attenuation of landfill leachate pollutants in aquifers. Crit. Rev. Environ. Sci. Technol. 1994, 24, 119-202.

(8) Sanin, F. D.; Knappe, D. R. U.; Barlaz, M. A. The fate of toluene, acetone and 1,2-dichloroethane in a laboratory-scale simulated landfill. Wat. Res. 2000, 34, 3063-3074.

(9) Schwartz, E. and Scow, K. M. Using biodegradation kinetics to measure availability of aged phenanthrene to bacteria inoculated into soil. Environ. Toxicol. Chem. 1999, 18, 1742-1746.

(10) Ham, R. K.; Norman, M. R.; Fritschel, P. R. Chemical characterization of fresh kills landfill refuse and extracts. J. Environ. Engineering. ASCE. 1993, 119, 1176-1195.

(11) Wang, Y.-S.; Byrd, C. S.; Barlaz, M. A. Anaerobic Biodegradability of Cellulose and Hemicellulose in Excavated Refuse Samples. J. Ind. Microbiol. 1994, 13, 147-153.

(12) Mehta, R.; Barlaz, M. A.; Yazdani, R.; Augenstein, D.; Bryars, M.; Sinderson, L.; Refuse Decomposition in the Presence and Absence of Leachate Recirculation, J. Env. Eng. 2002, 128, 228-236.

(13) Barlaz, M. A. Carbon storage during biodegradation of municipal solid waste components in laboratory-scale landfills. Global Biogeochem. Cycles 1998, 12, 373-380.

(14) Hatzinger, P. B.; Alexander, M. Effect of aging of chemicals in soil on their biodegradability and extractability. Environ. Sci. Technol. 1995, 29, 537-545.

(15) Dec, J.; Haider, K.; Benesi, A.; Rangaswamy, V.; Schäffer, A.; Plücken, U.; Bollag, J. M. Analysis of soilbound residues of ${ }^{13} \mathrm{C}$-labeled fungicide cyprodinil by NMR-spectroscopy. Environ. Sci. Technol. 1997, 31, 11281135 .

(16) Weber, W. J., Jr.; Huang, W. L. A distributed reactivity model for sorption by soils and sediments .4. Intraparticle heterogeneity and phase-distribution relationships under nonequilibrium conditions. Environ. Sci. Technol. 1996, 30, 881-888.

(17) Nam, K.; Alexander, M. Role of nanoporosity and hydrophobicity in sequestration and bioavailability: tests 
with model solids. Environ. Sci. Technol. 1998, 32, 71-74.

(18) White, J. C.; Hunter, M.; Nam, K.; Pignatello, J. J.; Alexander, M. Correlation between biological and physical availabilities of phenanthrene in soils and soil humin in aging experiments. Environ. Toxicol. Chem. 1999, 18, 17201727.

(19) Bollag, J. M.; Dec, J.; Huang, P. M. Formation mechanisms of complex organic structures in soil habitates. Advances in Agronomy 1998, 63, 237-266.

(20) Dec, J.; Bollag, J. M. Microbial release and degradation of catechol and chlorophenols bound to synthetic humic acid. Soil Sci. Soc. Am. J. 1988, 52, 1366-1371.

(21) Achtnich, C.; Fernandes, E.; Bollag, J. M.; Knackmuss, H. J.; Lenke, H. Covalent binding of reduced metabolites of $\left[{ }^{15} \mathrm{~N}_{3}\right]$ TNT to soil organic matter during a bioremediation process analyzed by ${ }^{15} \mathrm{~N}$ NMR spectroscopy. Environ. Sci. Technol. 1999, 33, 4448-4456.

(22) Wu, B. Y.; Taylor, C. M.; Knappe, D. R. U.; Nanny, M. A.; Barlaz, M. A. Factors controlling alkylbenzene sorption to municipal solid waste. Environ. Sci. Technol. 2001, 35, 4569-4576.

(23) Brock, T. D. and Madigan, M. T. (1991) Biology of Microorganisms. Prentice Hall

(24) Pelczar, M. J. Jr. and Reid, R. D. (1958) In Microbiology. McGraw Press. New York. p102-103

(25) Snoeyink, V. L. and Jenkins, D. Water Chemistry. Wiley, John \& Sons. 1991. pp299-305.

(26) Thurman, E. M.; Malcolm, R. L. Preparative isolation of aquatic humic substances. Environ. Sci. Technol. $1981,15,463-466$.

(27) Stevenson, F. L. Humus chemistry: Genesis, Composition, Reactions, 2nd Edition. 1994, John Wiley \& Sons, New York.

(28) Xing, B. S.; Pignatello, J. J.; Gigliotti, B. Competitive sorption between atrazine and other organic compounds in soils and model sorbents. Environ. Sci. Technol. 1996, 30, 2432-2440.

(29) Weber, W. J.; McGinley, P. M.; Katz, L. E. A distributed reactivity model for sorption by soils and sediments. 1. Conceptual basis and equilibrium assessments. Environ. Sci. Technol. 1992, 26, 1955-1962.

(30) Rogers, C.E., Stannett, V., Szwarc, M., The sorption diffusion and permeation of organic vapors in polyethylene. J. Polymer Sci. 1960. XLV, 61-82.

(31) Berens, A. R. Transport of organic vapors and liquids in poly(vinyl chloride). Makromol. Chem. Macromol. Symp. 1989. 29, 95-108.

(32) Wu, B. Y. 2002 Effect of Aging on the Bioavailability of Toluene Sorbed to Municipal Solid Waste Components. Ph.D. thesis. North Carolina State University. Raleigh, NC, USA.

http://www.lib.ncsu.edu/theses/available/etd-08152002-214123/unrestricted/etd.pdf 
(33) Wershaw, R. I. Model for Humus in Soils and Sediments. Environ. Sci. Technol. 1993, 27, 814-816.

(34) Guthrie, E. A.; Bortiatynski, J. M.; van Heemst, J. D. H.; Richman, J. E.; Hardy, K. S.; Kovach, E. M.; Hatcher, P. G. Determination of $\left[{ }^{13} \mathrm{C}\right]$ pyrene sequestration in sediment microcosms using flash prolysis-GC-MS and ${ }^{13} \mathrm{C}$ NMR. Environ. Sci. Technol. 1999, 33, 119-125.

(35) Alexander, M. Aging, bioavailability, and overestimation of risk from environmental pollutants. Environ. Sci. Technol. 2000, 34, 4259-4265.

(36) Reddy, C. M.; Quinn, J. G.; King, J. W. Free and bound benzotriazoles in marine and freshwater sediments. Environ. Sci. Technol. 2000, 34, 973-979.

(37) Tang, J. X.; Liste, H. H.; Alexander, M. Chemical assays of availability to earthworms of polycyclic aromatic hydrocarbons in soil. Chemosphere. 2002, 48, 35-42.

(38) Johnson, D. L.; Jones, K. C.; Langdon, C. J. Piearce, T. G.; Semple, K. T. Temporal changes in earthworm availability and extractability of polycyclic aromatic hydrocarbons in soil. Soil Biol. Biochem. 2002, 34, 1363-1370.

(39) Richnow, H. H.; Seifert, R.; Hefter, J.; Kästner, M.; Mahro, B.; Michaelis, W. Metabolites of xenobiotica and mineral oil constituents linked to macromolecular organic matter in polluted environments. Org. Geochem. 1993, $22,671-681$.

(40) Käcker, T.; Haupt, E. T. K.; Garms, C. Francke, W.; Steinhart, H. Structural characterisation of humic acidbound PAH residues in soil by C-13-CPMAS-NMR-spectroscopy: evidence of covalent bonds. Chemosphere. 2002, $48,117-131$.

(41) Richnow, H. H.; Seifert, R.; Hefter, J.; Link, M.; Francke, W.; Schaefer, G.; Michaelis, W. Organic pollutants associated with macromolecular soil organic matter: mode of binding. Org. Geochem. 1997, 26, 745-758.

(42) Dagley, S. Chapman, P. J.; Gibson, D. T.; Wood, J. M. Degradation of benzene nucleus by bacteria. Nature. 1964, 202, 775-761.

(43) Gibson, D. T.; Koch, J. R.; Schuld, C. L.; Kallio, R. E. Oxidative degradation of aromatic hydrocarbons by microorganisms. II. Metabolism of halogenated aromatic hydrocarbons. Biochemistry. 1968, 7, 3795-3802.

(44) Yu, H. B.; Kim, B. J.; Rittmann, B. E. The roles of intermediates in biodegradation of benzene, toluene, and pxylene by Pseudomonas putida F1. Biodegradation. 2001, 12, 455-463.

(45) Akin, D. E.; Hartley, R. D.; Rigsby, L. L.; Morrison, W. H. III. Phenolic acids released from Bermudagrass (Cynodon dactylon) by sequential sodium hydroxide treatment in relation to biodegradation of cell types. J. Sci. Food Agric. 1992, 58, 207-214.

(46) Simpson, A. J.; Kingery, W. L.; Hatcher, P. G. The identification of plant derived structures in humic materials using three-dimensional NMR spectroscopy. Environ. Sci. Technol. 2003, 37, 337-342.

(47) Jackson, M. G. Review article: the alkali treatment of straws. Anim. Feed Sci. Technol. 1977, 2, 105-130. 
(48) Scalbert, A.; Monties, B. Comparison of wheat straw lignin preparations. Holzforschung 1986, 40, 249-254.

(49) Tomotake, H.; Shimaoka, I.; Kayashita, J.; Nakajoh, M.; Kato, N. Physicochemical and functional properties of buckwheat protein product. J. Agric. Food Chem. 2002, 50, 2125-2129.

(50) Roberts, J. C. The Chemistry of Paper; The Royal Society of Chemistry: Herts, U.K., 1996.

(51) Xiao, B.; Sun, X. F.; Sun, R. Chemical, structural, and thermal characterizations of alkali-soluble lignins and hemicelluloses, and cellulose from maize stems, rye straw, and rice straw. Polym. Degrad. Stabil. 2001, 74, 307319.

(52) Durot, N.; Gaudard, F.; Kurek, B. The unmasking of lignin structures in wheat straw by alkali. Phytochemistry. 2003, 63, 617-623.

(53) Martens, D. A. Identification of phenolic acid composition of alkali-extracted plants and soils. Soil Sci. Soc. Am. J. 2002, 66, 1240-1248.

(54) Weber, W. J., Jr.; LeBoeuf, E. J.; Young, T. M.; Huang, W. Contaminant interactions with geosorbent organic matter: insights drawn from polymer sciences. Wat. Res. 2001, 35, 853-868.

(55) Hatcher, P. G.; Spiker, E. C. Selective degradation of plant biomolecules. In Aquatic and Terrestrial Humic Materials, eds Christman, R. F. and Gjessing, E. T. 1983, p59-74. Ann Arbor Science, Ann Arbor, MI.

(56) Aochi, Y. O.; Farmer, W. J. Role of microstructural properties in the time-dependent sorption/desorption behavior of 1,2-dichloroethane on humic substances. Environ. Sci. Technol. 1997, 31, 2520-2526.

(57) Hatcher, P. G.; Breger, I. A.; Maciel, G. E.; Szeverenyi, N. Geochemistry of humin. In Humic Substances in Soil, Sediment, and Water. Eds Aiken, G. R.; McKnight, D. M.; Wershaw, R. L.; MacCarthy, P.1985, p275-302. Wiley, New York.

(58) de Jonge, H.; de Jonge, L. W.; Mittelmeijer-Hazeleger, M. C. The microporous structure of organic and mineral soil materials. Soil. Sci. 2000, 165, 99-108.

(59) Ogram, A. V.; Jessup, R. E.; Ou, L. T.; Rao, P. S. C. Effects of sorption on biological degradation rates of (2, 4-Dichlorophenoxy)acetic acid in soils. Appl. Environ. Microbiol. 1985, 49, 582-587.

(60) Johnson, S. E.; Herman, J. S.; Mills, A. L.; Hornberger, G. M. Bioavailability and desorption characteristics of aged, nonextractable atrazine in soil. Environ. Toxicol. Chem. 1999, 18, 1747-1754.

(61) Rockne, K. J.; Shor, L. M.; Young, L. Y.; Taghon, G. L.; Kosson, D. S. Distributed sequestration and release of PAHs in weathered sediment: The role of sediment structure and organic carbon properties. Environ. Sci. Technol. 2002, 36, 2636-2644.

(62) Racke, K. D.; Lichtenstein, E. P. Effects of soil microorganisms on the release of bound ${ }^{14} \mathrm{C}$ residues from soils previously treated with $\left[{ }^{14} \mathrm{C}\right]$ Parathion. J. Agric. Food Chem. 1985, 33, 939-943.

(63) Guerin, W. F.; Boyd, S. A. Bioavailability of naphthalene associated with natural and synthetic sorbents. Water 
Res. 1997, 31, 1504-1512.

(64) Reinhart, D. R.; Gould, J.P.; Cross, W. H.; Pohland, F. G. Sorptive behavior of selected organic pollutants codisposed in a municipal landfill. In Hazardous Waste Management; Tedder, D. W., Pohland, F. G., Eds.; ACS Symposium Series 422; American Chemical Society: Washington, DC, 1990; pp292-310. 


\subsection{Tables and Figures for Manuscript 1}

\section{FIGURE 4.1 Bioavailability Reactor.}

Same as FIGURE 3.1.

TABLE 4.1 Degradation of Sorbents by PpF1

\begin{tabular}{ccccc}
\hline sorbent & $\begin{array}{c}\text { sorbent mass } \\
(\mathrm{g})\end{array}$ & $\mathrm{f}_{\mathrm{oc}}{ }^{\mathrm{a}}$ & \% C degraded $^{\mathrm{b}}$ & $\begin{array}{c}\text { Maximum daily } \mathrm{O}_{2} \text { demand } \\
(\mathrm{mg})^{\mathrm{c}}\end{array}$ \\
\hline fresh office paper & 3 & 0.373 & 1.18 & 24.67 \\
degraded office paper & 3 & 0.278 & 1.95 & 37.01 \\
fresh newsprint & 3 & 0.451 & 0.81 & 10.55 \\
degraded newsprint & 3 & 0.455 & 0.78 & 22.33 \\
fresh rabbit food & 2 & 0.423 & 34.53 & 547.51 \\
degraded rabbit food & 1.5 & 0.329 & 6.89 & 46.85 \\
\hline
\end{tabular}

${ }^{a}$ Fraction of organic carbon (Wu et al. 2001). ${ }^{b}$ The ratio of cumulative inorganic carbon produced to the organic carbon content of each sorbent. Values are averages of triplicate samples. ${ }^{\mathrm{c}}$ See text for calculation.

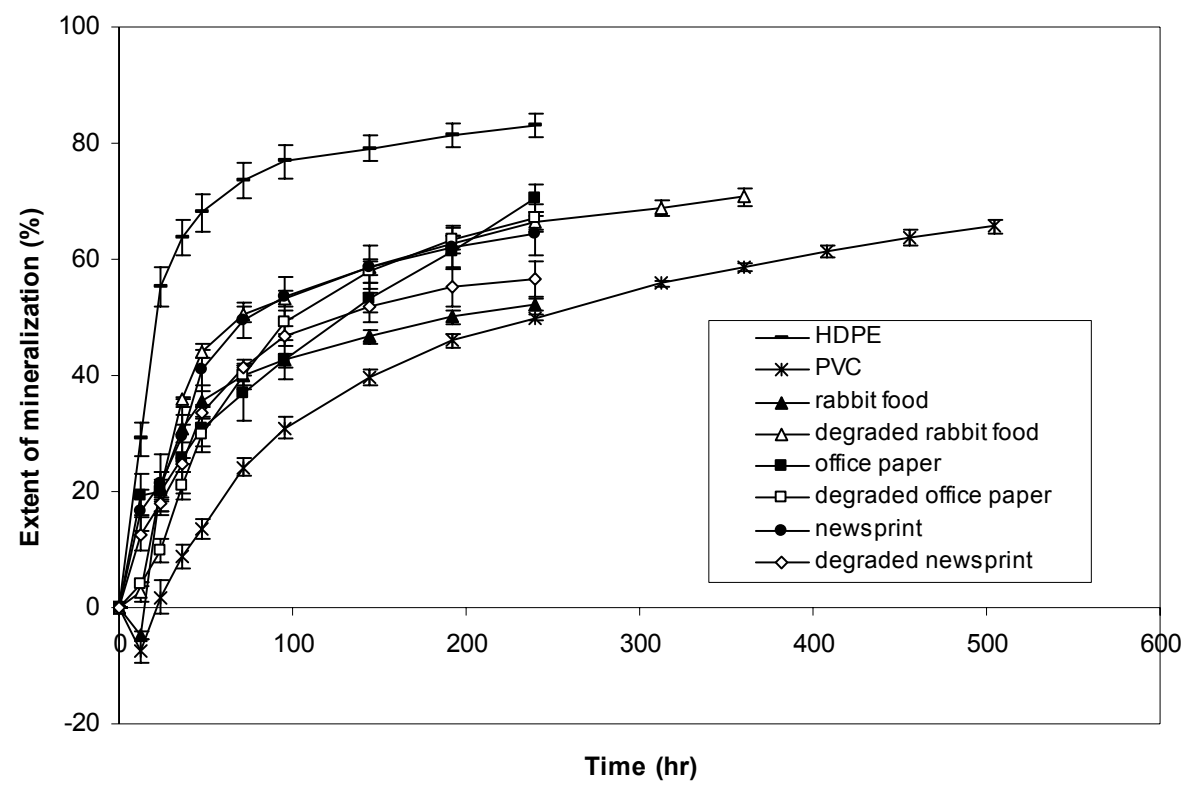

FIGURE 4.2 Bioavailability of Toluene Sorbed to MSW Components after 1-d aging as calculated from eqn. 1.

Data are averages of three replicates. Error bars represent standard deviations. Bioavailability tests were stopped when daily ${ }^{14} \mathrm{CO}_{2}$ increase was below $0.5 \%$ of total toluene added. 
TABLE 4.2 Mineralization of Toluene Sorbed to MSW Components at 200 hrs (\%) ${ }^{\text {a }}$

\begin{tabular}{cccc}
\hline sorbent & 1-d aging & 30-d aging & 180-d aging \\
\hline HDPE & $81.3(3.1) \mathrm{A}^{\mathrm{b}}$ & $80.6(1.3) \mathrm{A}$ & $78.7(1.2) \mathrm{A}$ \\
PVC & $46.0(1.3) \mathrm{A}$ & $37.9(1.1) \mathrm{B}$ & $34.2(0.3) \mathrm{C}$ \\
fresh office paper & $61.2(2.7) \mathrm{A}$ & $0^{\mathrm{c}}$ & $0^{\mathrm{c}}$ \\
degraded office paper & $63.2(2.2) \mathrm{A}$ & $38.8(1.9) \mathrm{B}$ & $32.9(2.2) \mathrm{C}$ \\
fresh newsprint & $61.1(3.7) \mathrm{A}$ & $44.4(2.7) \mathrm{B}$ & $43.7(1.6) \mathrm{B}$ \\
degraded newsprint & $56.7(3.1) \mathrm{A}$ & $46.1(1.3) \mathrm{B}$ & $45.2(1.5) \mathrm{B}$ \\
fresh rabbit food & $50.1(1.1)$ & na $^{\mathrm{d}}$ & na \\
degraded rabbit food & $62.9(1.2) \mathrm{A}$ & $53.9(3.7) \mathrm{B}$ & $43.8(3.0) \mathrm{C}$ \\
\hline
\end{tabular}

${ }^{\text {a }}$ Data are presented as the percent of the sorbed ${ }^{14} \mathrm{C}$-toluene that was converted to ${ }^{14} \mathrm{CO}_{2}$ as in eqn 1 . Values are averages of 3 or 4 samples. The values in parentheses are the standard deviations. ${ }^{b}$ Values in rows for the same sorbent followed by the same letter are not statistically different $(\mathrm{p}>0.05) .{ }^{\mathrm{C}}$ Mineralization in sorbent containing samples did not exceed that in the respective blanks. ${ }^{d}$ Not analyzed.

TABLE 4.3 Mineralization of Toluene Sorbed to MSW Components (\%) ${ }^{\mathrm{a}}$

\begin{tabular}{cccc}
\hline sorbent & 1-d aging & 30-d aging & 180-d aging \\
\hline HDPE & $82.9(1.9) \mathrm{A}^{\mathrm{b}}$ & $81.8(1.3) \mathrm{A}$ & $79.9(1.1) \mathrm{A}$ \\
PVC & $65.6(1.3) \mathrm{A}$ & $57.8(0.9) \mathrm{B}$ & $52.2(0.6) \mathrm{C}$ \\
fresh office paper & $66.1(2.2) \mathrm{A}$ & $0^{\mathrm{c}}$ & $0^{\mathrm{c}}$ \\
degraded office paper & $67.1(2.5) \mathrm{A}$ & $45.4(0.6) \mathrm{B}$ & $37.8(2.1) \mathrm{C}$ \\
fresh newsprint & $64.3(3.7) \mathrm{A}$ & $47.1(2.5) \mathrm{B}$ & $46.0(2.1) \mathrm{B}$ \\
degraded newsprint & $60.4(3.3) \mathrm{A}$ & $49.5(1.2) \mathrm{B}$ & $48.4(1.5) \mathrm{B}$ \\
fresh rabbit food & $52.1(1.0) \mathrm{A}$ & na $^{\mathrm{d}}$ & na $^{\mathrm{d}}$ \\
degraded rabbit food & $70.7(1.6) \mathrm{A}$ & $59.9(3.4) \mathrm{B}$ & $52.8(2.8) \mathrm{C}$ \\
\hline
\end{tabular}

${ }^{\text {a }}$ Data are presented as the percent of the sorbed ${ }^{14} \mathrm{C}$-toluene that was converted to ${ }^{14} \mathrm{CO}_{2}$ as in eqn. 1 . Values are averages of 3 or 4 replicates. The values in parentheses are the standard deviations. ${ }^{b}$ Values in rows for the same sorbent followed by the same letter are not statistically different $(p>0.05) .{ }^{c}$ Mineralization in solid containing samples did not exceed that in their respective blanks. ${ }^{\mathrm{d}}$ Not analyzed.

TABLE 4.4 pH at the Termination of Bioavailability Tests for Selected Sorbents

\begin{tabular}{ccccc}
\hline sorbent & $\mathrm{CaCO}_{3}$ in sorbent $(\mathrm{g})$ & 1-d aging & 30-d aging & 180-d aging \\
\hline fresh office paper & 0.268 & 7.01 & 8.65 & 9.10 \\
degraded office paper & 0.537 & 7.50 & 8.68 & 9.32 \\
fresh newsprint & 0.006 & 7.59 & 6.94 & 6.96 \\
degraded newsprint & 0.016 & na $^{\text {a }}$ & 6.84 & 6.92 \\
degraded rabbit food & 0.060 & na $^{\text {a }}$ & 7.24 & 7.33 \\
\hline
\end{tabular}

${ }^{a}$ Not analyzed. 
TABLE 4.5 Distribution of Radioactivity (\%)

\begin{tabular}{|c|c|c|c|c|c|c|c|c|c|c|c|}
\hline \multirow[b]{2}{*}{ sorbent } & \multirow{2}{*}{$\begin{array}{l}\text { aging } \\
\text { time } \\
\text { (d) }\end{array}$} & \multirow[b]{2}{*}{ sorbed $^{\mathrm{b}}$} & \multirow[b]{2}{*}{${ }^{14} \mathrm{CO}_{2}{ }^{\mathrm{a}}$} & \multirow{2}{*}{$\begin{array}{c}\text { particulate } \\
\text { and cell } \\
\text { mass }{ }^{\mathrm{a}, \mathrm{c}}\end{array}$} & \multirow{2}{*}{$\begin{array}{c}\text { non- } \\
\text { volatile }{ }^{14} \mathrm{C} \\
\text { in liquid }{ }^{\mathrm{a}}\end{array}$} & \multirow{2}{*}{$\begin{array}{c}\text { solvent } \\
\text { extractable } \\
\mathrm{a}, \mathrm{d}\end{array}$} & \multicolumn{4}{|c|}{ humic substances } & \multirow{2}{*}{$\begin{array}{c}\text { total } \\
\text { recovery } \\
\mathrm{a}, \mathrm{g}\end{array}$} \\
\hline & & & & & & & HA & FA & $\mathrm{NH}$ & humin & \\
\hline PVC & 1 & $\begin{array}{l}53.7 \\
(2.1) \\
\end{array}$ & $\begin{array}{l}68.5 \\
(0.7) \\
\end{array}$ & $\begin{array}{c}9.1 \\
(1.9) \\
\end{array}$ & $\begin{array}{c}2.0 \\
(0.1) \\
\end{array}$ & $\begin{array}{l}19.3 \\
(0.3) \\
\end{array}$ & \multicolumn{4}{|c|}{$\mathrm{na}^{\mathrm{e}}$} & $\begin{array}{l}98.8 \\
(1.9) \\
\end{array}$ \\
\hline PVC & 30 & $\begin{array}{l}89.7 \\
(0.5)\end{array}$ & $\begin{array}{l}56.4 \\
(0.8)\end{array}$ & $\begin{array}{c}5.6 \\
(0.1)\end{array}$ & $\begin{array}{c}1.7 \\
(0.2)\end{array}$ & $\begin{array}{l}36.2 \\
(0.7)\end{array}$ & \multicolumn{4}{|c|}{ na } & $\begin{array}{l}99.9 \\
(1.3)\end{array}$ \\
\hline PVC & 180 & $\begin{array}{l}91.8 \\
(0.2)\end{array}$ & $\begin{array}{l}52.3 \\
(0.6)\end{array}$ & $\begin{array}{c}5.6 \\
(0.1)\end{array}$ & $\begin{array}{c}2.3 \\
(0.4)\end{array}$ & $\begin{array}{l}37.4 \\
(0.7)\end{array}$ & \multicolumn{4}{|c|}{ na } & $\begin{array}{l}97.6 \\
(0.7)\end{array}$ \\
\hline HDPE & 1 & $\begin{array}{l}75.9 \\
(0.7)\end{array}$ & $\begin{array}{l}78.4 \\
(0.1)\end{array}$ & $\begin{array}{l}16.4 \\
(0.6)\end{array}$ & $\begin{array}{c}2.6 \\
(0.1)\end{array}$ & $\begin{array}{c}3.4 \\
(0.1)\end{array}$ & \multicolumn{4}{|c|}{ na } & $\begin{array}{l}100.9 \\
(0.4)\end{array}$ \\
\hline HDPE & 30 & $\begin{array}{l}75.9 \\
(1.1)\end{array}$ & $\begin{array}{l}75.7 \\
(1.0)\end{array}$ & $\begin{array}{l}19.5 \\
(1.7)\end{array}$ & $\begin{array}{c}3.4 \\
(0.1) \\
\end{array}$ & $\begin{array}{c}2.8 \\
(0.1) \\
\end{array}$ & \multicolumn{4}{|c|}{ na } & $\begin{array}{l}101.3 \\
(2.2) \\
\end{array}$ \\
\hline HDPE & 180 & $\begin{array}{l}75.9 \\
(0.6)\end{array}$ & $\begin{array}{l}72.5 \\
(1.0)\end{array}$ & $\begin{array}{l}20.8 \\
(3.0)\end{array}$ & $\begin{array}{c}4.4 \\
(0.1) \\
\end{array}$ & $\begin{array}{c}2.5 \\
(0.2) \\
\end{array}$ & \multicolumn{4}{|c|}{ na } & $\begin{array}{l}100.3 \\
(1.8) \\
\end{array}$ \\
\hline $\begin{array}{c}\text { fresh } \\
\text { office paper }\end{array}$ & 1 & $\begin{array}{l}16.3 \\
(1.8)\end{array}$ & $\begin{array}{l}66.1 \\
(0.4)\end{array}$ & $\begin{array}{l}10.0 \\
(0.7)\end{array}$ & $\begin{array}{c}2.5 \\
(0.2)\end{array}$ & $\begin{array}{c}2.4 \\
(0.3)\end{array}$ & $n d^{\mathrm{f}}$ & nd & nd & $\begin{array}{c}7.8 \\
(0.9)\end{array}$ & $\begin{array}{l}88.8 \\
(1.2)\end{array}$ \\
\hline $\begin{array}{c}\text { fresh } \\
\text { office paper }\end{array}$ & 30 & $\begin{array}{l}23.5 \\
(2.5)\end{array}$ & $\begin{array}{l}49.3 \\
(0.8)\end{array}$ & $\begin{array}{l}10.4 \\
(0.0)\end{array}$ & $\begin{array}{c}5.9 \\
(0.1)\end{array}$ & $\begin{array}{c}3.3 \\
(0.3)\end{array}$ & nd & $\begin{array}{c}4.8 \\
(0.0)\end{array}$ & $\begin{array}{c}0.6 \\
(0.0)\end{array}$ & $\begin{array}{l}13.8 \\
(0.4)\end{array}$ & $\begin{array}{l}88.1 \\
(1.5)\end{array}$ \\
\hline $\begin{array}{c}\text { fresh } \\
\text { office paper }\end{array}$ & 180 & $\begin{array}{l}26.7 \\
(1.7)\end{array}$ & $\begin{array}{l}43.6 \\
(0.8)\end{array}$ & $\begin{array}{l}11.3 \\
(2.3)\end{array}$ & $\begin{array}{l}16.2 \\
(3.3)\end{array}$ & $\begin{array}{c}1.2 \\
(0.6)\end{array}$ & nd & $\begin{array}{c}2.9 \\
(0.5)\end{array}$ & $\begin{array}{c}1.2 \\
(0.5)\end{array}$ & $\begin{array}{l}14.7 \\
(1.2)\end{array}$ & $\begin{array}{l}90.4 \\
(1.8)\end{array}$ \\
\hline $\begin{array}{l}\text { degraded } \\
\text { office paper }\end{array}$ & 1 & $\begin{array}{l}37.8 \\
(0.2) \\
\end{array}$ & $\begin{array}{l}71.0 \\
(1.0) \\
\end{array}$ & $\begin{array}{c}7.9 \\
(0.3) \\
\end{array}$ & $\begin{array}{c}2.3 \\
(0.0) \\
\end{array}$ & $\begin{array}{c}4.9 \\
(0.4) \\
\end{array}$ & nd & $\begin{array}{c}1.5 \\
(0.3) \\
\end{array}$ & $\begin{array}{c}0.6 \\
(0.1) \\
\end{array}$ & $\begin{array}{c}5.8 \\
(0.2) \\
\end{array}$ & $\begin{array}{l}94.4 \\
(1.2) \\
\end{array}$ \\
\hline $\begin{array}{l}\text { degraded } \\
\text { office paper }\end{array}$ & 30 & $\begin{array}{l}41.4 \\
(0.9)\end{array}$ & $\begin{array}{l}61.2 \\
(0.3)\end{array}$ & $\begin{array}{c}7.1 \\
(0.3)\end{array}$ & $\begin{array}{c}9.4 \\
(0.2)\end{array}$ & $\begin{array}{c}5.8 \\
(0.4)\end{array}$ & nd & $\begin{array}{c}2.1 \\
(0.3)\end{array}$ & $\begin{array}{l}1.7 \\
(0.4)\end{array}$ & $\begin{array}{c}8.8 \\
(0.9)\end{array}$ & $\begin{array}{l}91.6 \\
(0.6)\end{array}$ \\
\hline $\begin{array}{l}\text { degraded } \\
\text { office paper }\end{array}$ & 180 & $\begin{array}{l}42.1 \\
(0.4)\end{array}$ & $\begin{array}{l}54.3 \\
(0.4)\end{array}$ & $\begin{array}{c}4.7 \\
(0.2)\end{array}$ & $\begin{array}{l}16.6 \\
(0.0)\end{array}$ & $\begin{array}{c}5.0 \\
(0.3)\end{array}$ & nd & $\begin{array}{c}0.9 \\
(0.0)\end{array}$ & $\begin{array}{c}1.3 \\
(0.2)\end{array}$ & $\begin{array}{l}10.4 \\
(0.3)\end{array}$ & $\begin{array}{l}93.4 \\
(1.0)\end{array}$ \\
\hline $\begin{array}{c}\text { fresh } \\
\text { newsprint }\end{array}$ & 1 & $\begin{array}{l}42.0 \\
(0.3)\end{array}$ & $\begin{array}{l}71.8 \\
(0.4)\end{array}$ & $\begin{array}{c}6.1 \\
(0.6)\end{array}$ & $\begin{array}{c}2.3 \\
(0.0)\end{array}$ & $\begin{array}{c}3.6 \\
(0.2)\end{array}$ & $\begin{array}{c}1.7 \\
(0.0)\end{array}$ & $\begin{array}{c}1.4 \\
(0.1)\end{array}$ & $\begin{array}{c}1.2 \\
(0.1)\end{array}$ & $\begin{array}{c}3.7 \\
(0.6)\end{array}$ & $\begin{array}{l}92.2 \\
(1.0)\end{array}$ \\
\hline $\begin{array}{c}\text { fresh } \\
\text { newsprint }\end{array}$ & 30 & $\begin{array}{l}46.3 \\
(0.8) \\
\end{array}$ & $\begin{array}{l}63.5 \\
(1.1) \\
\end{array}$ & $\begin{array}{c}5.6 \\
(0.4) \\
\end{array}$ & $\begin{array}{c}5.1 \\
(0.1) \\
\end{array}$ & $\begin{array}{c}4.0 \\
(0.3) \\
\end{array}$ & $\begin{array}{c}2.6 \\
(0.5) \\
\end{array}$ & $\begin{array}{c}2.0 \\
(0.1)\end{array}$ & $\begin{array}{c}1.1 \\
(0.1)\end{array}$ & $\begin{array}{c}6.5 \\
(0.7) \\
\end{array}$ & $\begin{array}{l}90.3 \\
(1.1) \\
\end{array}$ \\
\hline $\begin{array}{c}\text { fresh } \\
\text { newsprint }\end{array}$ & 180 & $\begin{array}{l}46.6 \\
(0.9)\end{array}$ & $\begin{array}{l}61.1 \\
(0.3)\end{array}$ & $\begin{array}{c}5.9 \\
(0.1)\end{array}$ & $\begin{array}{c}8.1 \\
(0.0)\end{array}$ & $\begin{array}{c}2.7 \\
(0.3)\end{array}$ & $\begin{array}{c}2.2 \\
(0.0)\end{array}$ & $\begin{array}{c}2.5 \\
(0.1)\end{array}$ & $\begin{array}{c}1.5 \\
(0.3)\end{array}$ & $\begin{array}{c}8.6 \\
(1.2)\end{array}$ & $\begin{array}{l}92.6 \\
(1.1)\end{array}$ \\
\hline $\begin{array}{l}\text { degraded } \\
\text { newsprint }\end{array}$ & 1 & $\begin{array}{l}45.9 \\
(0.7) \\
\end{array}$ & $\begin{array}{l}67.4 \\
(1.6)\end{array}$ & $\begin{array}{c}9.2 \\
(0.4)\end{array}$ & $\begin{array}{c}3.2 \\
(0.2) \\
\end{array}$ & $\begin{array}{c}6.6 \\
(0.3) \\
\end{array}$ & $\begin{array}{c}2.9 \\
(0.5)\end{array}$ & $\begin{array}{c}1.3 \\
(0.1) \\
\end{array}$ & $\begin{array}{c}0.5 \\
(0.1) \\
\end{array}$ & $\begin{array}{c}6.0 \\
(0.3)\end{array}$ & $\begin{array}{l}97.1 \\
(0.9)\end{array}$ \\
\hline $\begin{array}{l}\text { degraded } \\
\text { newsprint }\end{array}$ & 30 & $\begin{array}{l}48.2 \\
(1.1) \\
\end{array}$ & $\begin{array}{l}62.4 \\
(1.3) \\
\end{array}$ & $\begin{array}{c}9.4 \\
(0.8) \\
\end{array}$ & $\begin{array}{c}3.2 \\
(0.1) \\
\end{array}$ & $\begin{array}{c}7.0 \\
(0.3) \\
\end{array}$ & $\begin{array}{c}3.0 \\
(0.9) \\
\end{array}$ & $\begin{array}{c}1.8 \\
(1.1) \\
\end{array}$ & $\begin{array}{c}0.4 \\
(0.0) \\
\end{array}$ & $\begin{array}{c}7.0 \\
(0.5) \\
\end{array}$ & $\begin{array}{l}94.0 \\
(2.9) \\
\end{array}$ \\
\hline $\begin{array}{c}\text { degraded } \\
\text { newsprint }\end{array}$ & 180 & $\begin{array}{l}49.5 \\
(1.8) \\
\end{array}$ & $\begin{array}{c}63.0 \\
(0.0) \\
\end{array}$ & $\begin{array}{c}6.3 \\
(0.7) \\
\end{array}$ & $\begin{array}{c}2.7 \\
(0.1) \\
\end{array}$ & $\begin{array}{c}8.3 \\
(0.5) \\
\end{array}$ & $\begin{array}{c}2.1 \\
(0.1) \\
\end{array}$ & $\begin{array}{c}2.7 \\
(0.1) \\
\end{array}$ & $\begin{array}{c}1.3 \\
(0.1) \\
\end{array}$ & $\begin{array}{l}10.2 \\
(0.6) \\
\end{array}$ & $\begin{array}{l}93.5 \\
(0.7) \\
\end{array}$ \\
\hline $\begin{array}{c}\text { fresh } \\
\text { rabbit food }\end{array}$ & 1 & $\begin{array}{l}41.6 \\
(1.3)\end{array}$ & $\begin{array}{l}62.4 \\
(0.5)\end{array}$ & $\begin{array}{l}10.1 \\
(0.5)\end{array}$ & $\begin{array}{c}4.4 \\
(0.7)\end{array}$ & $\begin{array}{c}5.6 \\
(0.6)\end{array}$ & $\begin{array}{c}2.4 \\
(0.2)\end{array}$ & $\begin{array}{c}1.8 \\
(0.2)\end{array}$ & $\begin{array}{c}2.4 \\
(0.2)\end{array}$ & $\begin{array}{l}1.0 \\
(0.2)\end{array}$ & $\begin{array}{l}91.2 \\
(1.0)\end{array}$ \\
\hline $\begin{array}{l}\text { degraded } \\
\text { rabbit food }\end{array}$ & 1 & $\begin{array}{l}39.6 \\
(0.7)\end{array}$ & $\begin{array}{l}70.8 \\
(0.7)\end{array}$ & $\begin{array}{l}11.8 \\
(0.6)\end{array}$ & $\begin{array}{c}4.5 \\
(0.1)\end{array}$ & $\begin{array}{c}4.1 \\
(0.1)\end{array}$ & $\begin{array}{c}0.3 \\
(0.0)\end{array}$ & $\begin{array}{c}1.1 \\
(0.0)\end{array}$ & $\begin{array}{c}1.1 \\
(0.1)\end{array}$ & $\begin{array}{c}0.7 \\
(0.1)\end{array}$ & $\begin{array}{l}94.4 \\
(0.4)\end{array}$ \\
\hline $\begin{array}{c}\text { degraded } \\
\text { rabbit food }\end{array}$ & 30 & $\begin{array}{l}39.7 \\
(0.2) \\
\end{array}$ & $\begin{array}{l}65.7 \\
(1.4) \\
\end{array}$ & $\begin{array}{l}10.9 \\
(0.2) \\
\end{array}$ & $\begin{array}{c}4.8 \\
(0.2) \\
\end{array}$ & $\begin{array}{c}4.5 \\
(0.2) \\
\end{array}$ & $\begin{array}{c}2.5 \\
(0.0) \\
\end{array}$ & $\begin{array}{c}0.8 \\
(0.1) \\
\end{array}$ & $\begin{array}{c}0.9 \\
(0.1) \\
\end{array}$ & $\begin{array}{c}0.9 \\
(0.0) \\
\end{array}$ & $\begin{array}{l}91.1 \\
(1.2) \\
\end{array}$ \\
\hline $\begin{array}{l}\text { degraded } \\
\text { rabbit food }\end{array}$ & 180 & $\begin{array}{l}39.8 \\
(0.5)\end{array}$ & $\begin{array}{l}63.4 \\
(0.4)\end{array}$ & $\begin{array}{l}11.7 \\
(0.3)\end{array}$ & $\begin{array}{c}6.2 \\
(0.7)\end{array}$ & $\begin{array}{c}4.6 \\
(0.2)\end{array}$ & $\begin{array}{c}0.7 \\
(0.0)\end{array}$ & $\begin{array}{c}2.3 \\
(0.8)\end{array}$ & $\begin{array}{c}2.1 \\
(0.3)\end{array}$ & $\begin{array}{c}1.3 \\
(0.1)\end{array}$ & $\begin{array}{l}92.2 \\
(0.5)\end{array}$ \\
\hline
\end{tabular}


${ }^{a}$ Data are presented as a percentage of the total amount of toluene added initially corrected for volatile loss. Data are the averages of three ampoules for each sorbent and the standard deviation is presented parenthetically. ${ }^{\mathrm{b}}{ }^{14} \mathrm{C}$ in solid phase before inoculation. Data were presented without correction for volatile loss. ${ }^{\mathrm{c}}$ Includes biomass and particulates. ${ }^{\mathrm{d}}$ Solvent is benzyl alcohol.. ${ }^{\mathrm{e}}$ Not analyzed. ${ }^{\mathrm{f}}$ Radioactivity was not detected. The detection limit varies with the amount of toluene added initially and ranged from $0.001-0.002 \% .{ }^{\mathrm{g}}$ Total recovery includes ${ }^{14} \mathrm{C}$ recovered as ${ }^{14} \mathrm{CO}_{2}$, particulate and biomass, non-volatile, solvent extractable and humic substances associated ${ }^{14} \mathrm{C}$.

TABLE 4.6 Solvent Extraction of Radioactivity by Benzyl Alcohol (\%) ${ }^{\mathrm{a}}$

\begin{tabular}{cccc}
\hline sorbent & 1-d aging & 30-d aging & 180-d aging \\
\hline fresh office paper & $25.8(1.4) \mathrm{A}$ & $14.1(0.6) \mathrm{B}$ & $6.01(2.9) \mathrm{C}$ \\
degraded office paper & $38.5(0.5) \mathrm{A}$ & $31.4(2.3) \mathrm{B}$ & $28.2(0.3) \mathrm{C}$ \\
fresh newsprint & $31.5(1.6) \mathrm{A}$ & $25.2(1.5) \mathrm{B}$ & $15.3(0.1) \mathrm{C}$ \\
degraded newsprint & $38.9(2.4) \mathrm{A}$ & $36.5(1.1) \mathrm{B}$ & $33.9(1.0) \mathrm{C}$ \\
fresh rabbit food & $42.4(4.7)$ & na $^{\mathrm{c}}$ & na $^{\mathrm{c}}$ \\
degraded rabbit food & $55.5(0.9) \mathrm{A}$ & $46.6(3.0) \mathrm{B}$ & $41.4(2.7) \mathrm{C}$ \\
\hline
\end{tabular}

${ }^{a}$ Values are the percentage of benzyl alcohol extracted ${ }^{14} \mathrm{C}$ based on the total activity remaining on a sorbent after bioavailability testing was complete. Data in parentheses are the standard deviations. ${ }^{b}$ Values in rows for the same sorbent followed by the same letter are not statistically different $(\mathrm{p}>0.05) .{ }^{\mathrm{c}}$ Not analyzed.

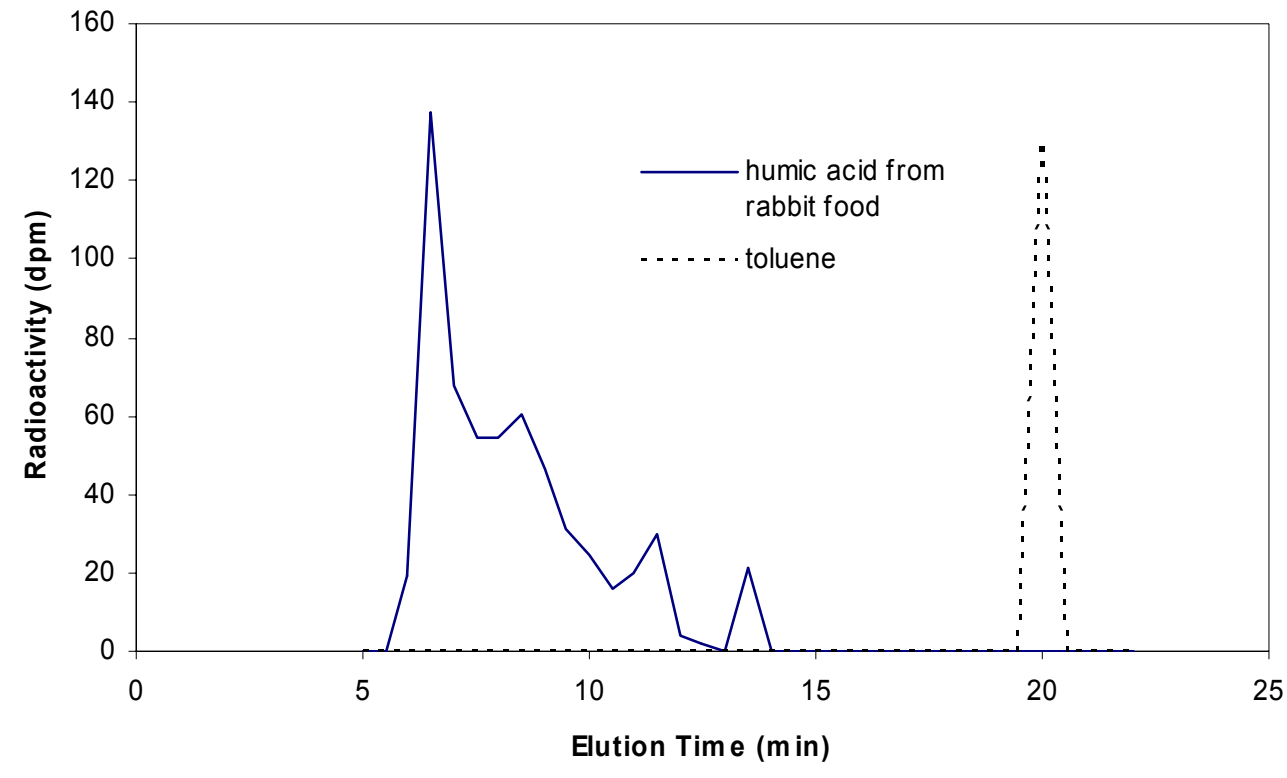

FIGURE 4.3 HPSEC chromatogram of humic acid extracted from rabbit food.

The humic acid fraction was adjusted to $\mathrm{pH}$ 6. Eluent was collected and analyzed by scintillation counting. 
TABLE 4.7 Distribution of Non Purgable Organic Carbon (NPOC) in Humic Matter (\%) ${ }^{\text {a }}$

\begin{tabular}{cccccccccc}
\hline & \multicolumn{3}{c}{ 1-d aging } & \multicolumn{3}{c}{ 30-d aging } & \multicolumn{3}{c}{ 180-d aging } \\
\cline { 2 - 10 } & $\mathrm{HA}^{\mathrm{b}}$ & $\mathrm{NH}^{\mathrm{b}}$ & $\mathrm{FA}^{\mathrm{b}}$ & $\mathrm{HA}$ & $\mathrm{NH}$ & FA & HA & $\mathrm{NH}$ & $\mathrm{FA}$ \\
\hline fresh office paper & $\mathrm{nd}^{\mathrm{c}}$ & $\mathrm{nd}$ & $\mathrm{nd}$ & $\mathrm{nd}$ & 1.3 & 98.7 & nd & 1.4 & 98.6 \\
fresh newsprint & 4.4 & 5.0 & 90.6 & 13.3 & 3.2 & 83.5 & 3.8 & 1.3 & 94.9 \\
degraded newsprint & 21.1 & 2.4 & 76.5 & 15.2 & 2.4 & 82.4 & 10.1 & 1.4 & 88.5 \\
fresh rabbit food & 7.6 & 4.5 & 87.9 & na $^{\mathrm{d}}$ & na & na & na & na & na \\
degraded rabbit food & 2.1 & 5.3 & 93.4 & 11.6 & 4.1 & 84.4 & 8.9 & 2.4 & 89.7 \\
\hline
\end{tabular}

${ }^{a}$ Values are the percentage of NPOC in one fraction based on the total NPOC in the NaOH extract. Data are averages of triplicate samples. $\mathrm{CV} \leq 26.6 \%{ }^{\mathrm{b}} \mathrm{HA}$ - humic acid, $\mathrm{NH}$ - non-humic matter, FA - fulvic acid ${ }^{\mathrm{c}}$ Radioactivity was not detected. ${ }^{\mathrm{d}}$ Not analyzed.

TABLE 4.8 Association of Radioactivity by Humic Substances

\begin{tabular}{|c|c|c|c|c|c|c|c|c|c|}
\hline \multirow{3}{*}{ Sorbent } & \multicolumn{9}{|c|}{$\left[{ }^{14} \mathrm{C}\right] / \mathrm{NPOC}(\mathrm{dpm} / \mathrm{mg})^{\mathrm{a}}$} \\
\hline & \multicolumn{3}{|c|}{ 1-d aging } & \multicolumn{3}{|c|}{ 30-d aging } & \multicolumn{3}{|c|}{ 180-d aging } \\
\hline & HA & $\mathrm{NH}$ & FA & HA & $\mathrm{NH}$ & FA & HA & $\mathrm{NH}$ & FA \\
\hline fresh office paper & $\mathrm{nd}^{\mathrm{b}}$ & nd & nd & nd & 0.19 & 0.02 & nd & 0.24 & 0.01 \\
\hline degraded office paper & nd & 0.20 & 0.01 & nd & 0.30 & 0.03 & nd & 1.43 & 0.02 \\
\hline fresh newsprint & 0.37 & 0.24 & 0.02 & 0.15 & 0.27 & 0.02 & 0.13 & 0.68 & 0.02 \\
\hline degraded newsprint & 0.12 & 0.18 & 0.02 & 0.20 & 0.18 & 0.02 & 0.16 & 0.72 & 0.02 \\
\hline fresh rabbit food & 0.27 & 0.46 & 0.02 & $\mathrm{na}^{\mathrm{c}}$ & na & na & na & na & na \\
\hline degraded rabbit food & 0.31 & 0.39 & 0.02 & 0.40 & 0.40 & 0.02 & 0.15 & 1.61 & 0.04 \\
\hline
\end{tabular}

${ }^{a}$ Values are averages of duplicate or triplicate samples. $\mathrm{CV} \leq 28.2 \% .{ }^{\mathrm{b}}$ Radioactivity was not detected. ${ }^{\mathrm{c}}$ Not analyzed.

TABLE 4.9 Association of Radioactivity with Humin Fraction (\%) ${ }^{\text {a }}$

\begin{tabular}{cccc}
\hline sorbent & 1-d aging & 30-d aging & 180 -d aging \\
\hline fresh office paper & $80.4(2.0) \mathrm{A}^{\mathrm{b}}$ & $61.1(0.8) \mathrm{B}$ & $73.8(0.4) \mathrm{A}$ \\
degraded office paper & $45.2(0.1) \mathrm{A}$ & $47.9(1.9) \mathrm{B}$ & $59.1(0.3) \mathrm{C}$ \\
fresh newsprint & $31.6(3.3) \mathrm{A}$ & $39.9(1.2) \mathrm{B}$ & $49.4(1.8) \mathrm{C}$ \\
degraded newsprint & $34.2(0.8) \mathrm{A}$ & $36.7(3.6) \mathrm{B}$ & $41.1(0.9) \mathrm{C}$ \\
fresh rabbit food & $7.4(1.6) \mathrm{A}$ & $\mathrm{na}^{\mathrm{c}}$ & $\mathrm{na}^{\mathrm{c}}$ \\
degraded rabbit food & $9.5(1.5) \mathrm{A}$ & $9.4(0.3) \mathrm{A}$ & $10.8(0.2) \mathrm{A}$ \\
\hline
\end{tabular}

${ }^{\text {a }}$ Data are percentage of radioactivity associated with humin fraction based on the total activity remaining on the sorbents after bioavailability testing. Values are averages of triplicate samples. The values in parentheses are the standard deviations. ${ }^{b}$ Values in rows for the same sorbent followed by the same letter are not statistically different $(\mathrm{p}>0.05) .{ }^{\mathrm{c}}$ not analyzed. 


\subsection{Supporting Information for Manuscript 1}

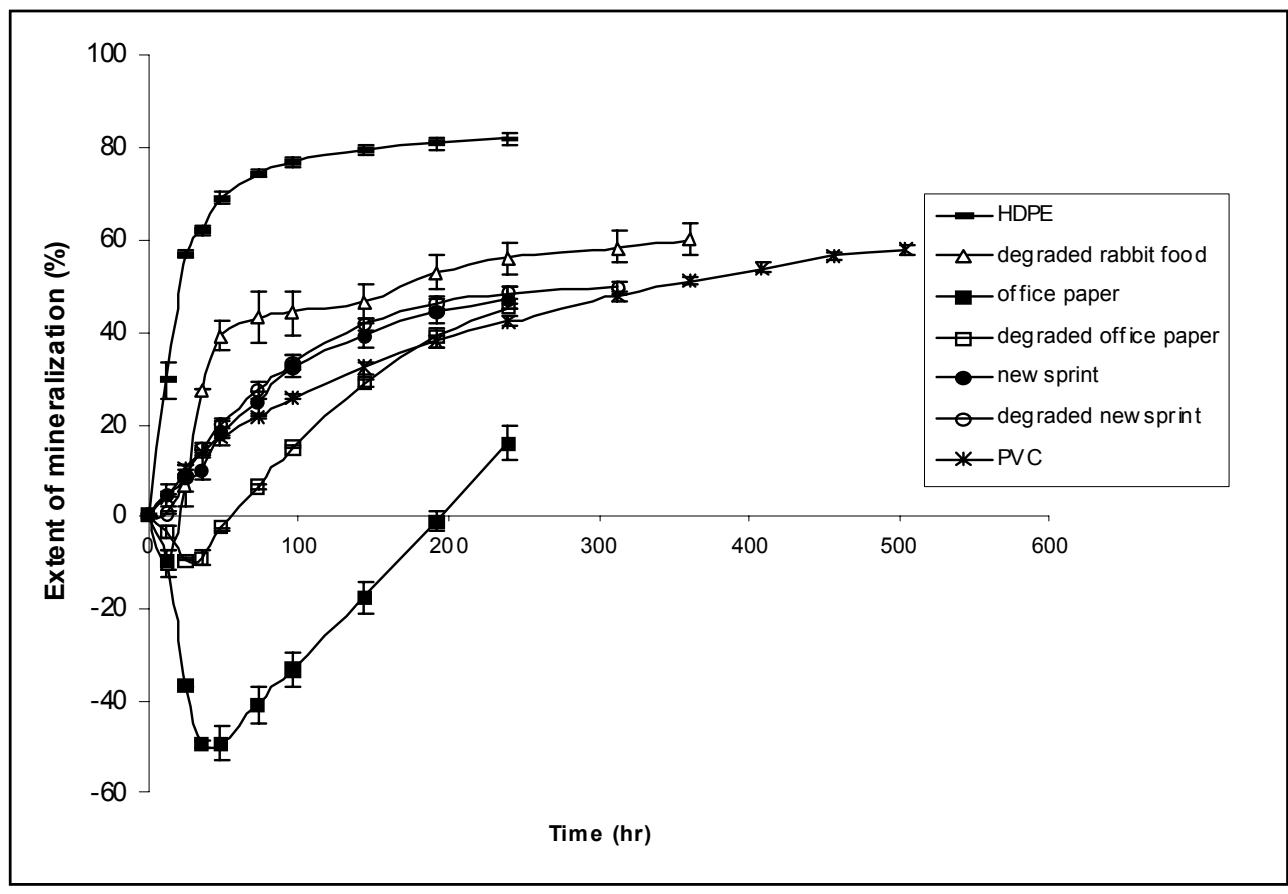

FIGURE S4.1 Bioavailability of Toluene Sorbed to MSW Component after 30-d aging.

Data are averages of three replicates. Error bars represent standard deviations.

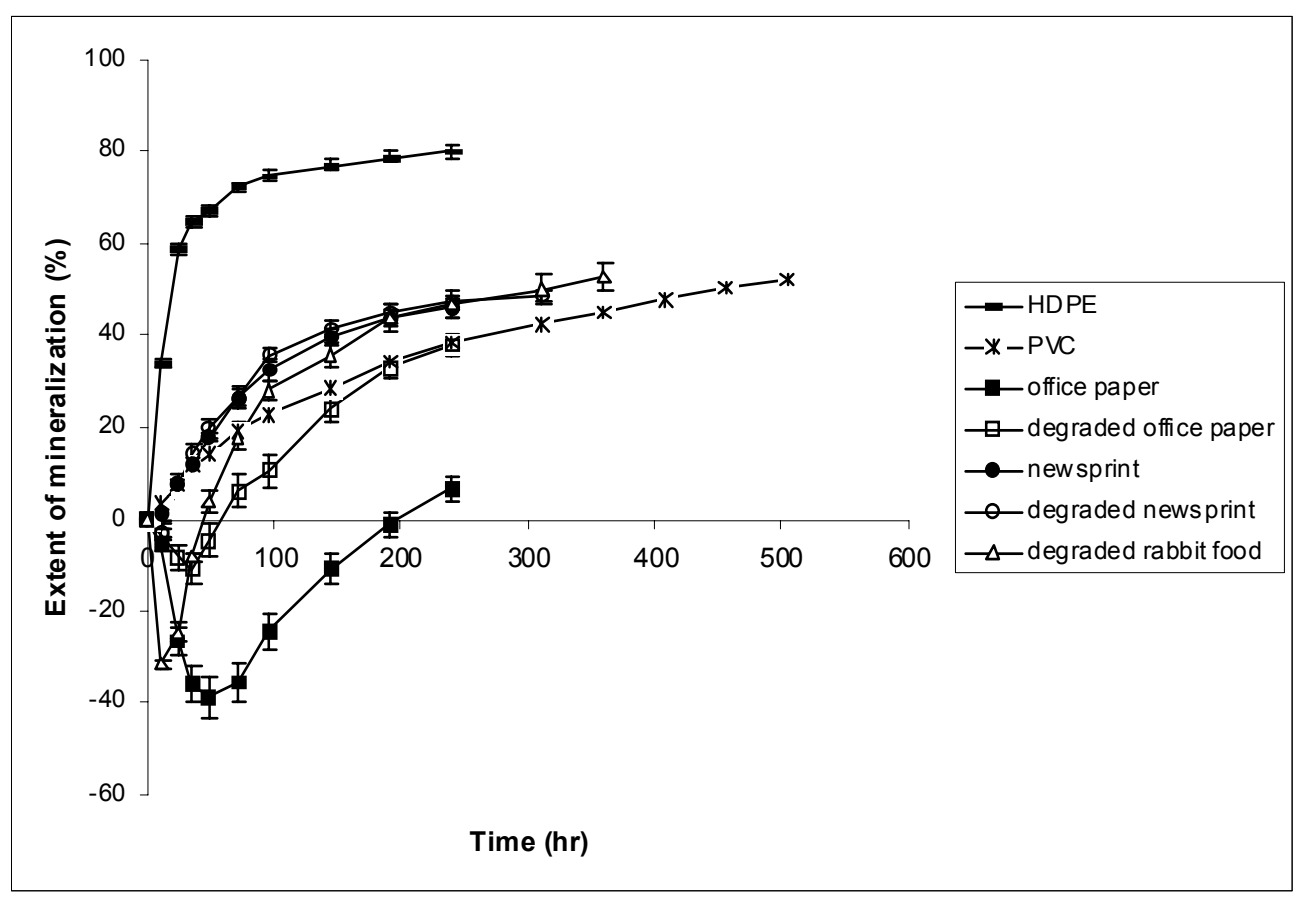

FIGURE S4.2 Bioavailability of Toluene Sorbed to MSW Component after 180-d aging.

Data are averages of three replicates. Error bars represent standard deviations. 

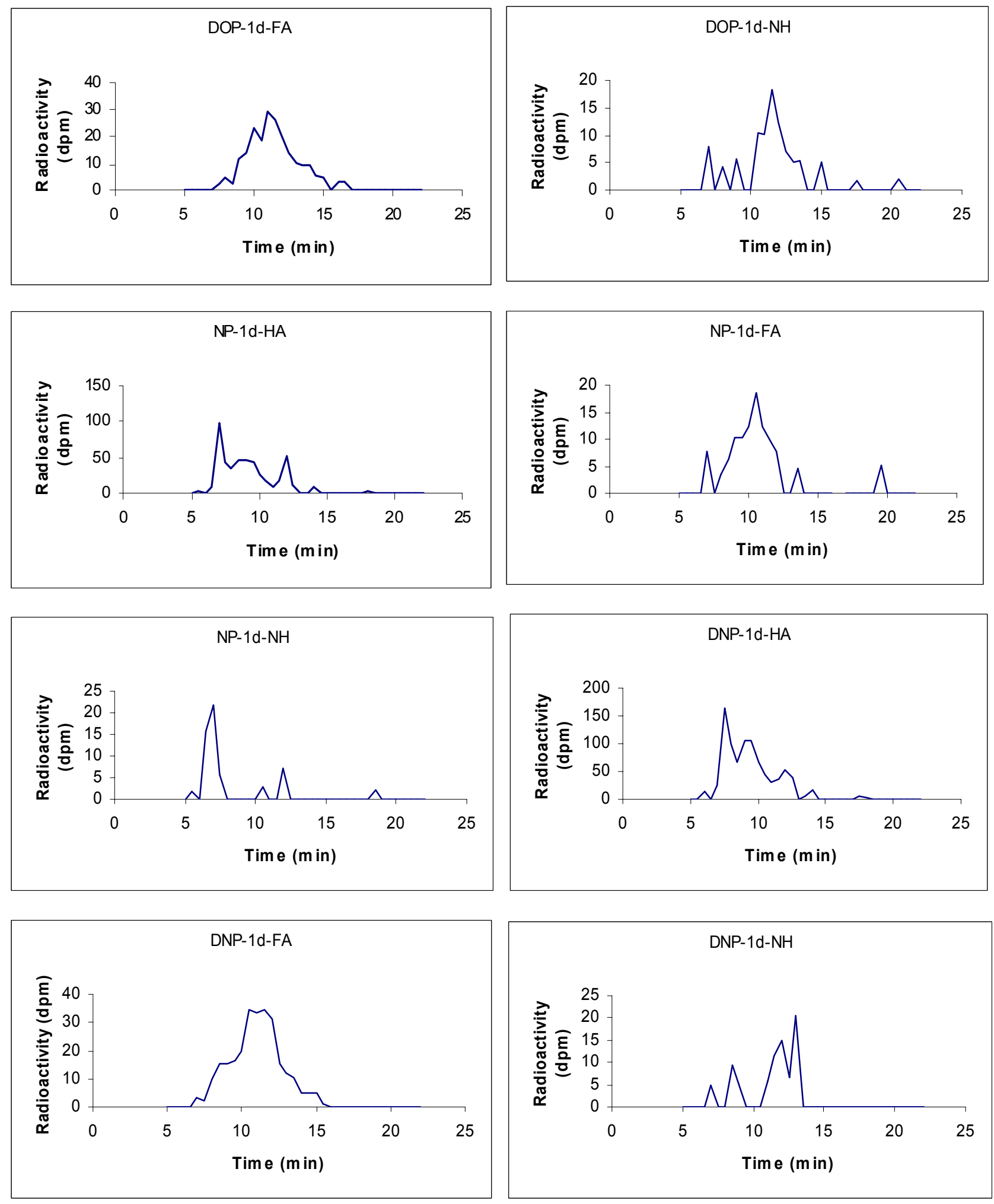

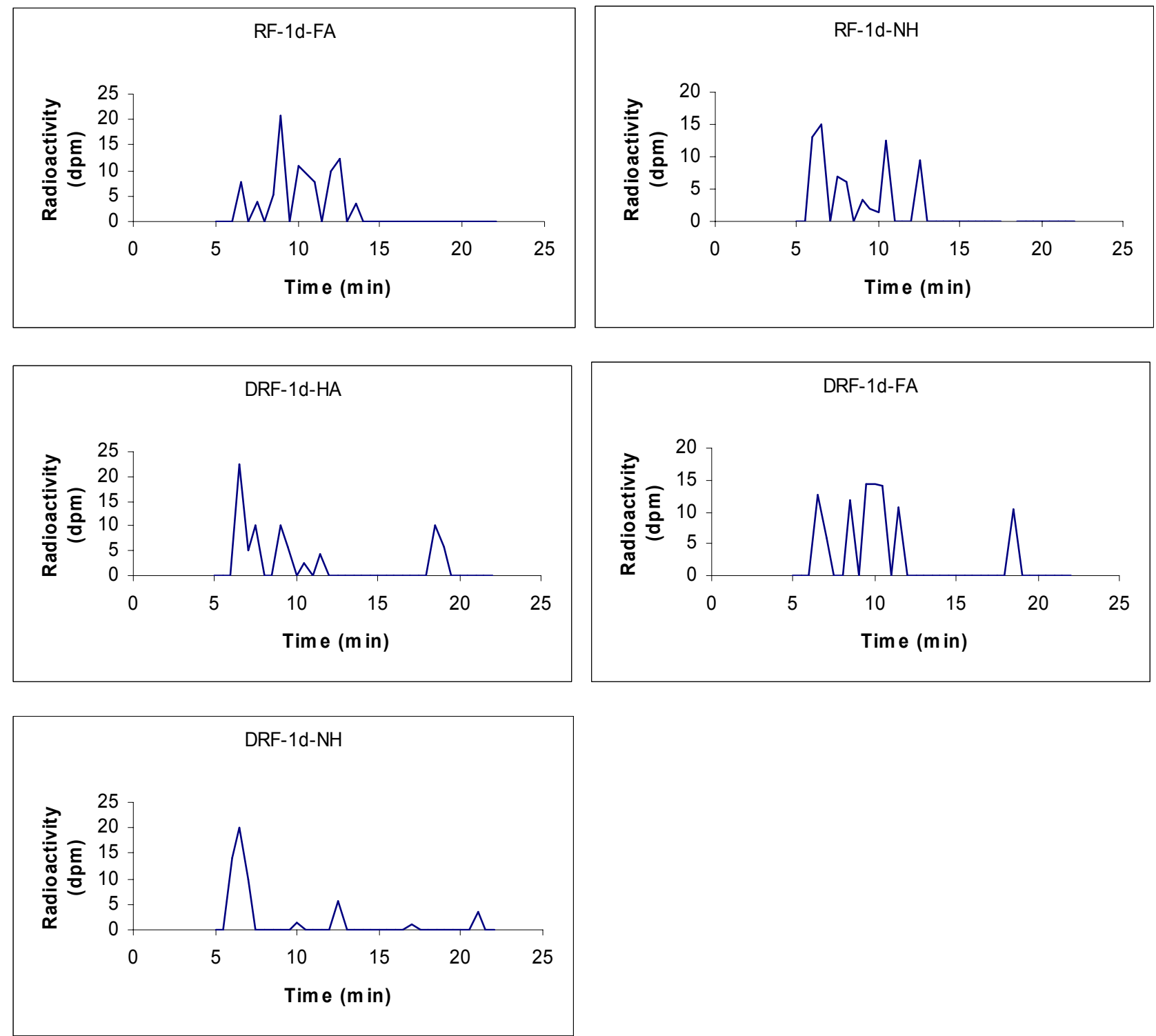

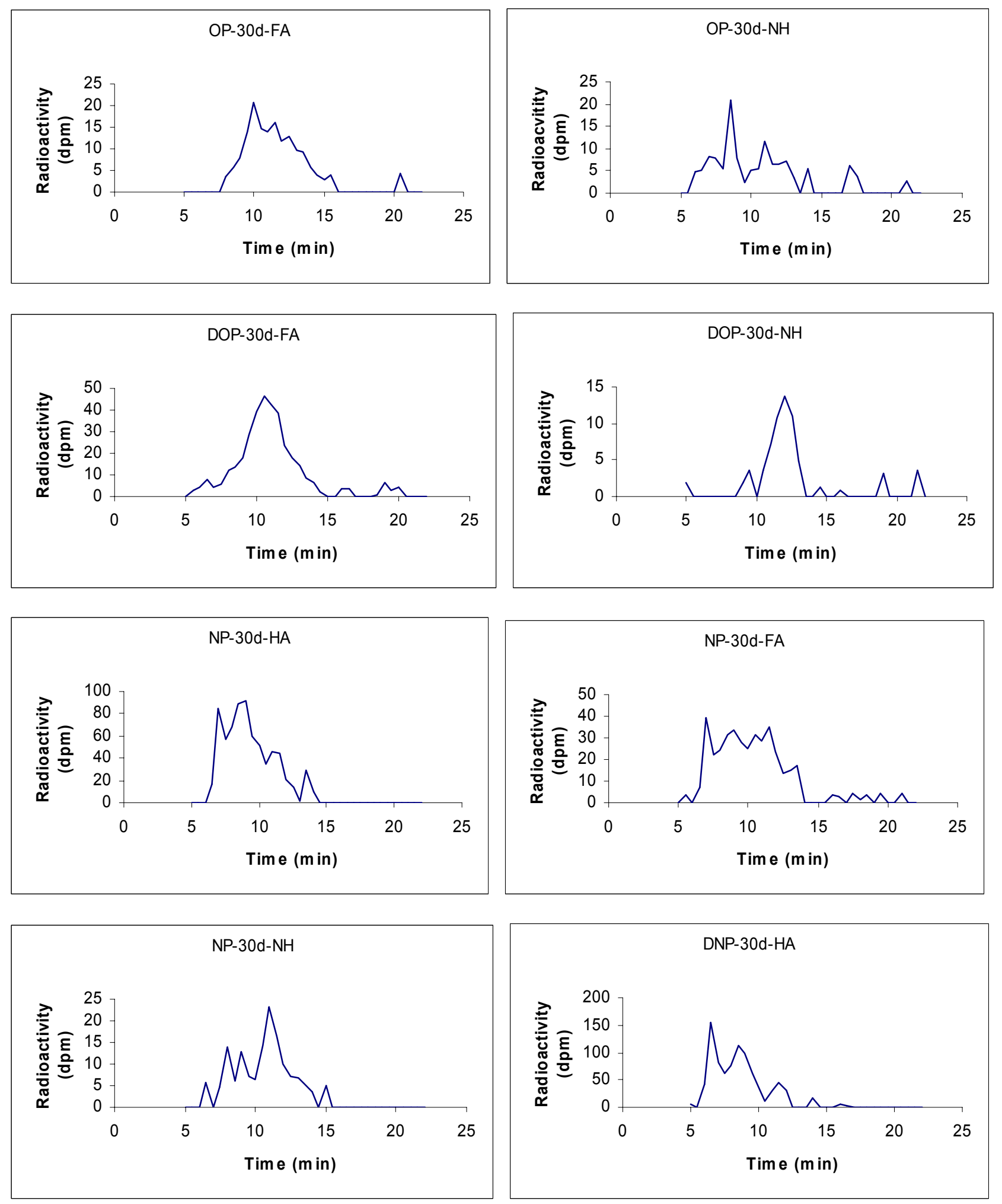

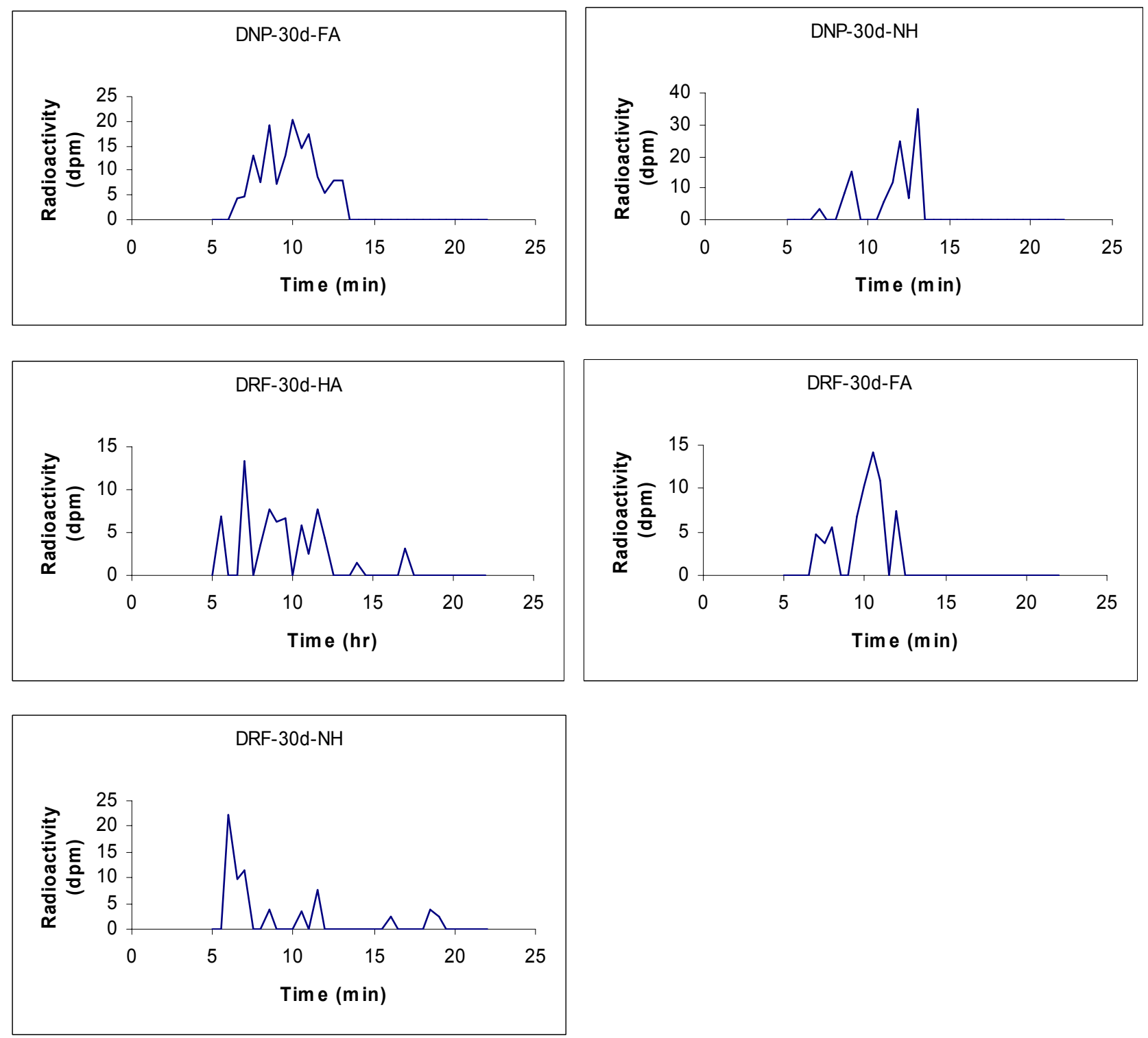

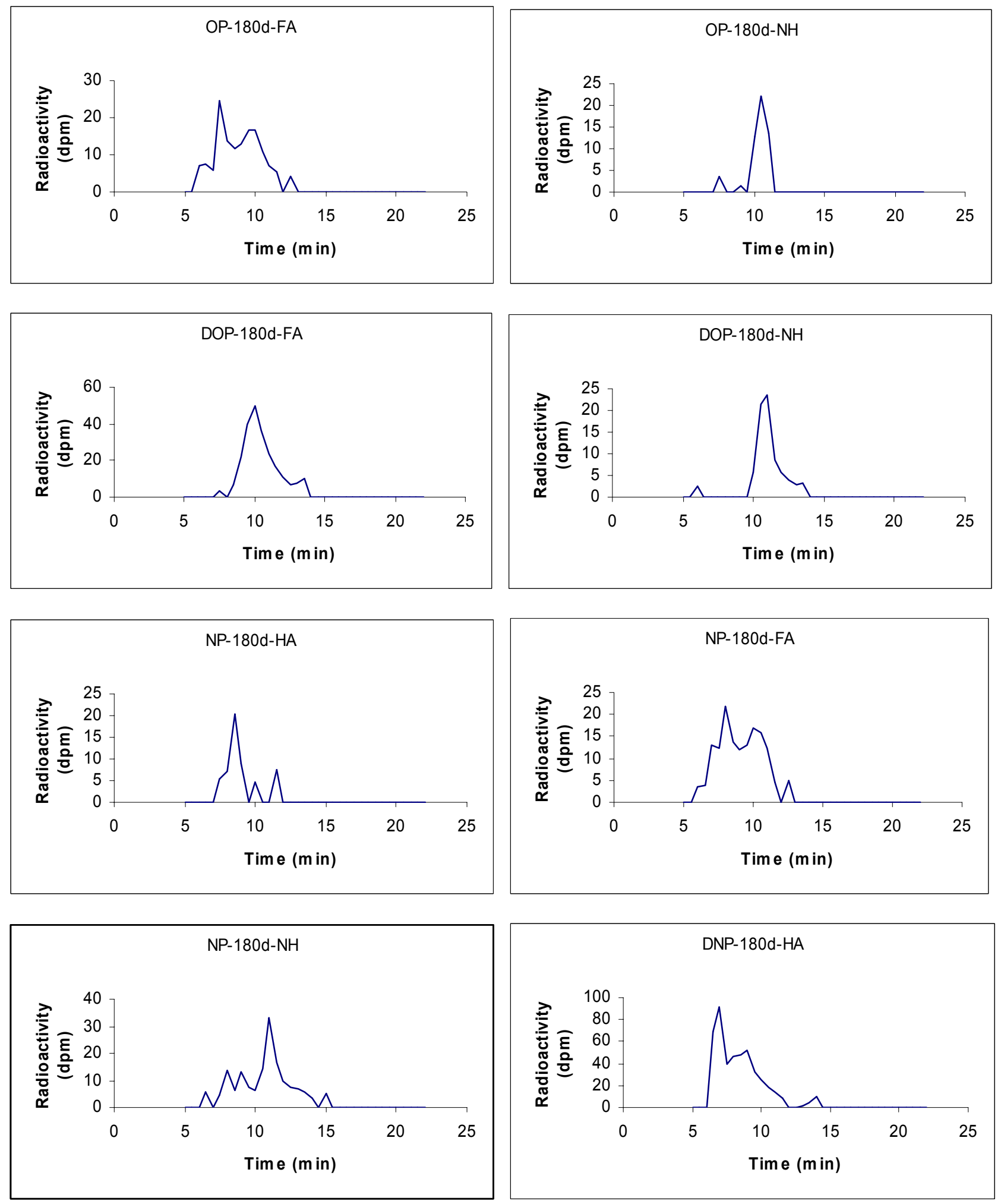

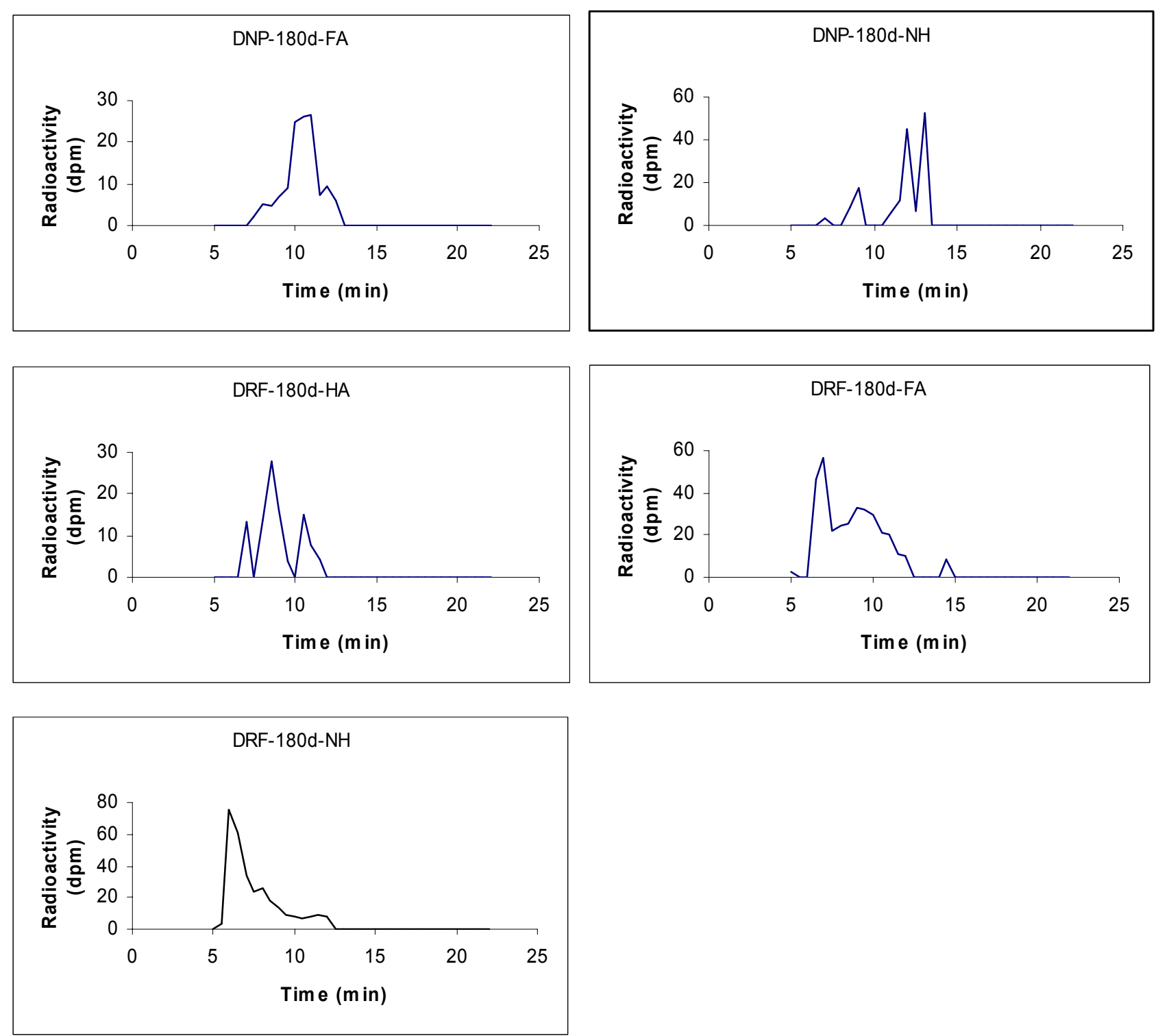

\section{FIGURE S4.3 HPSEC chromatogram of humic substances extracted from MSW Component.}

The humic substances were adjusted to $\mathrm{pH}$ 6. Eluent was collected and analyzed by scintillation counting. Abbreviations: HA-humic acid; FA-fulvic acid; NH-non-humic substances. OP-fresh office paper; DOP-degraded office paper; NP-fresh newsprint; DNP-degraded newsprint; RF-fresh rabbit food; DRF-degraded rabbit food; 1d-1 day aging; 30d-30 days aging; 180d-180 days aging. 


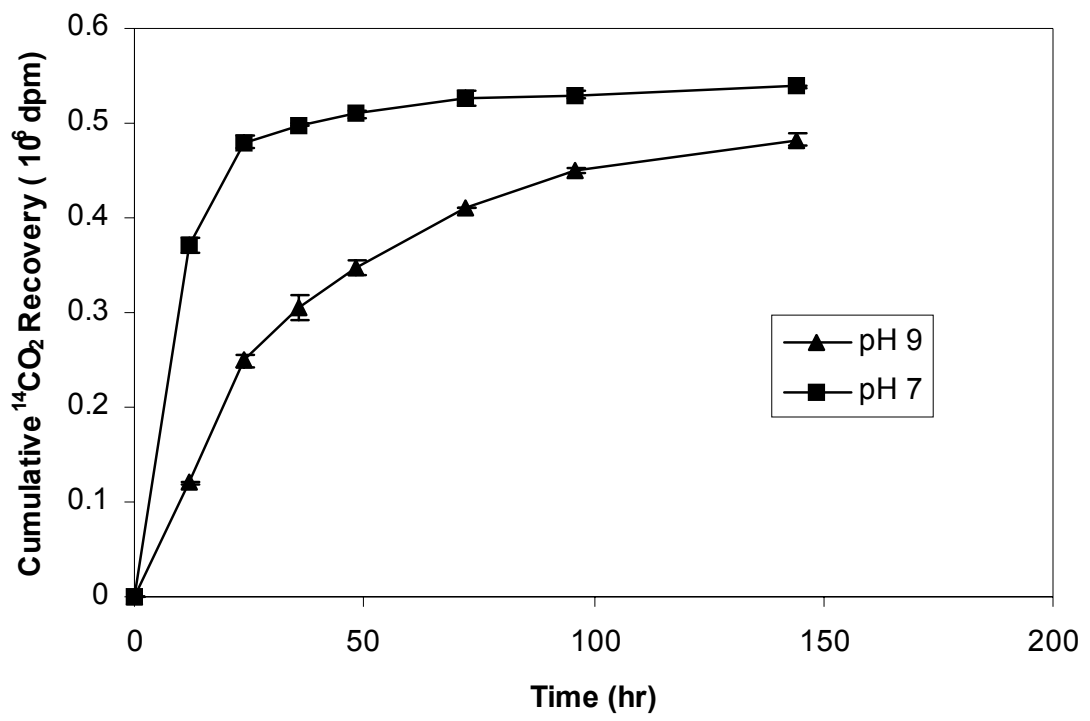

FIGURE S4.4 Comparison of biodegradation of toluene by PpF1 at different pH.

Data are averages of duplicate samples. Error bars represent standard deviations.

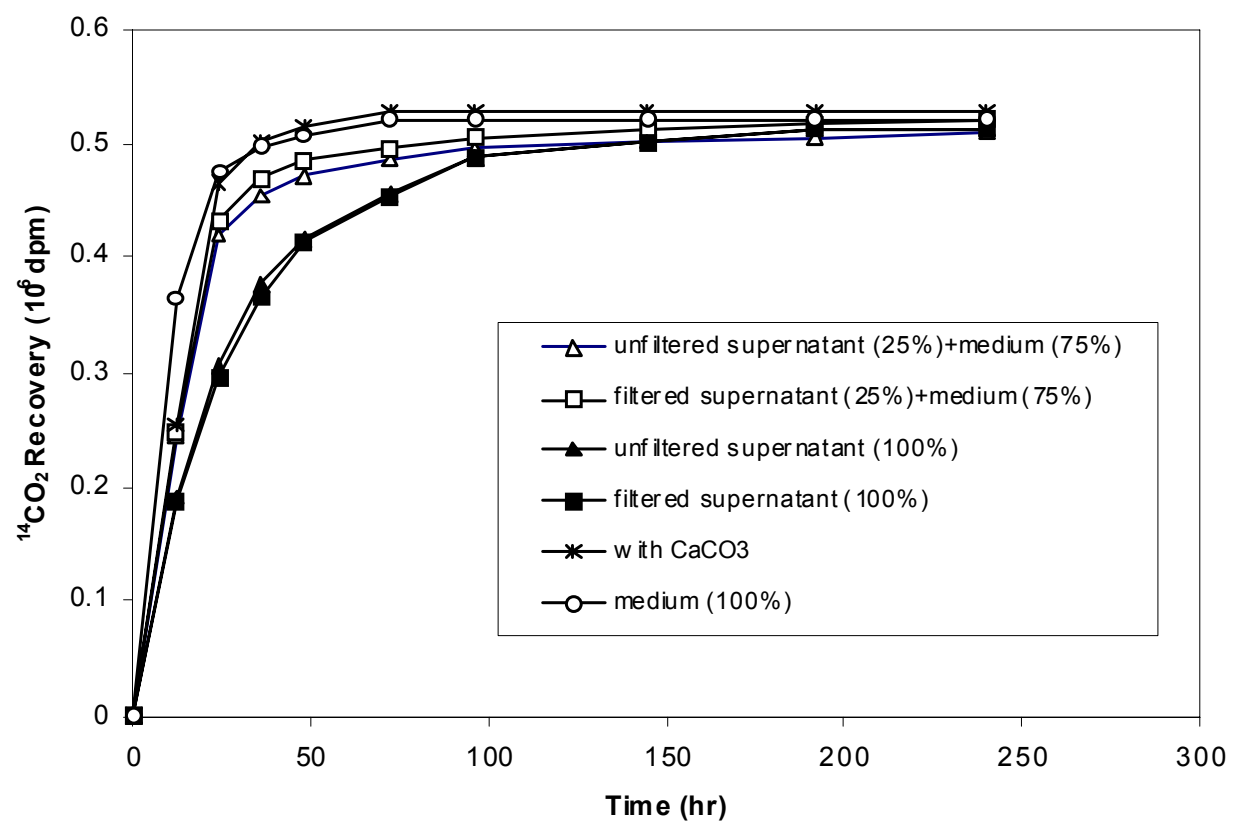

FIGURE S4.5 Comparison of toluene biodegradation in different preparations of fresh office paper blanks.

Office paper and $\mathrm{CaCO}_{3}$ were soaked with growth medium for 30 days. Data are averages of duplicate samples. $\mathrm{CV} \leq 22 \%$. 


\title{
4.4 The Effect of Cellulose Plus Hemicellulose and Lignin on the Bioavailability of Toluene Sorbed to Waste Paper
}

\begin{abstract}
Lignocellulosic materials make up about $38 \%$ of municipal solid waste, much of which is disposed in landfills. Organic contaminant sorption to lignocellulosic materials may limit contaminant bioavailability in landfills. The objective of this study was to identify the effect of individual biopolymers in paper on toluene sorption and bioavailability by subjecting office paper and newsprint to enzymatic hydrolysis and acid hydrolysis. Cellulose and hemicellulose exhibited little sorptive capacity for toluene while lignin controlled toluene sorption and bioavailability for both fresh and degraded newsprint. However, the presence of lignin could explain only 54\% of the toluene sorptive capacity of degraded office paper, suggesting that crude protein and lipophilic extractives such as sizing agent and/or cell wall compounds were important contributors to the toluene sorption capacity. Lignin extracted from degraded newsprint exhibited a $9.5 \%$ lower toluene sorption capacity than that extracted from fresh newsprint, a result that was attributable to incomplete protein removal during lignin purification and the comparatively lower toluene sorption capacity of protein.
\end{abstract}

\section{Introduction}

In the year 2000, there were 1967 operating municipal waste landfills in the US in addition to thousands of closed sites (U.S.EPA, 2002). While modern landfills are designed to contain waste and to collect leachate, this was not always the case. As recently as 1986, many landfills were constructed without an engineered liner (U.S.EPA, 1988). Prior to promulgation of the Resource Conservation and Recovery Act in 1976, the types of waste that could be buried in landfills were not strictly regulated. As a result, groundwater contamination is associated with many older landfills and at least $15 \%$ of today's Superfund sites are municipal landfills that received hazardous waste (U.S.EPA 2003). 
Some biodegradation and attenuation of organic contaminants occurs in landfills (Hilger and Barlaz, 2001). For example, studies that utilized liquid extracts of refuse microorganisms have documented the anaerobic biodegradation of phenol, toluene, $\mathrm{p}$ cresol (Wang and Barlaz 1998) and selected phthalic acid esters (Ejlertsson et al. 1996, Jonsson et al. 2003). Landfill leachate also has been shown to harbor microorganisms capable of PCE and TCE dehalogenation (Kromann and Christensen 1998). However, the fact that leachate contains a variety of xenobiotic organic chemicals suggests that biodegradation and other attenuating mechanisms in landfills are incomplete (Hilger and Barlaz, 2001).

One of the primary factors controlling the fate of hydrophobic organic compounds (HOCs) in the environment is sorption to organic matter (Alexander 1995, Luthy et al. 1997). Paper is the largest component of municipal solid waste (MSW) (U.S.EPA 2002). As such, the major components of paper, cellulose, hemicellulose and lignin, account for most of the organic matter in landfills. While the decomposition of cellulose and hemicellulose in landfills is well documented (Stinson and Ham 1995, Eleazer et al. 1997, Pichler and Kögel-Knabner 2000), their complete biodegradation is not expected as they are present in lignocellulosic complexes. The covalent linkage between polysaccharides and lignin provides physical blockage and renders cellulose and hemicellulose less susceptible to microbial attack (Tong et al. 1990, Eleazer et al. 1997, Tuomela et al. 2000). Concurrently, landfill organic matter decomposition leads to the accumulation of cellular materials such as proteins and lipids (Pichler and KögelKnabner 2000).

Recent work has indicated that biopolymers exhibited a wide range of sorptive capacity for HOCs. The partition coefficients describing HOC sorption to cellulose have been reported to be $0.02 \mathrm{~mL} / \mathrm{g}$ for toluene (Garbarini and Lion 1986); $1.0,2.6 \mathrm{~mL} / \mathrm{g}$ for benzene and o-xylene (Xing et al. 1994); 6.45, 3.50, $0.57 \mathrm{~mL} / \mathrm{g}$ for acetamide pesticides alachlor, metolachlor and propachlor (Torrents et al. 1997); 0.25, 0.51, 0.32 for atrazine, prometon and TCE, respectively (Xing et al. 1996). Lignin has much higher sorptive capacity for HOCs relative to cellulose. The partition coefficients were $97.2 \mathrm{~mL} / \mathrm{g}$ for 
toluene (Garbarini and Lion 1986); 402, 460, $140 \mathrm{~mL} / \mathrm{g}$ for alachlor, metolachlor, and propachlor (Torrents et al. 1997); 58.8 and $327 \mathrm{~mL} / \mathrm{g}$ for benzene and o-xylene respectively (Xing et al. 1994). Wood pulp and fiber is a complex conglomeration of individual biopolymers. The sorption of HOC to wood is consistent with their sorption to individual biopolymers. Mackay and Gschwend (2000) investigated the sorption of monoaromatic hydrocarbons to wood. They found the lignin-water partition coefficient, which was calculated from wood-water partition coefficient and lignin content, agreed with that of the chemically isolated lignin. Severtson and Banerjee (1996) also reported that retention of chlorophenols by wood fibers is governed by the interaction of the acid form of the chlorophenols with lignin.

Despite the large number of landfills that contain organic contaminants, HOC sorption to and desorption from lignocellulosic waste remains largely unexplored. The objective of this study was to identify the effects of individual biopolymers in paper on the sorption and bioavailability of toluene, a model alkylbenzene. Toluene was chosen as the test compound because of its frequent occurrence in landfill leachate (Christensen et al. 1994).

\section{Materials and Methods}

Experimental Design. Tests were conducted to evaluate the role of cellulose plus hemicellulose and lignin in paper on the bioavailability and sequestration of toluene. Office paper (OP) and newsprint (NP) were selected to represent the range of papers with respect to chemical composition (Table 4.10). OP is a chemical pulp that is nearly completely delignified, while NP is a mechanical pulp that still contains most of the lignin from trees. OP and NP were tested in both fresh and anaerobically degraded forms to evaluate the effect of sorbent decomposition on HOC sorption (degraded office paper and degraded newsprint are referred to as DOP and DNP, respectively).

To evaluate the effect of cellulose and hemicellulose on toluene bioavailability, these compounds were partially removed from paper by enzymatic hydrolysis. First, sorbents containing toluene were generated by exposing each paper type to toluene. Bioavailable 
toluene was subsequently consumed by an aerobic toluene degrading bacterium, Pseudomonas putida F1 (PpF1). Toluene bioavailability was assessed by measurement of the conversion of ${ }^{14} \mathrm{C}$-toluene to ${ }^{14} \mathrm{CO}_{2}$ (Hatzinger and Alexander 1995). Once daily ${ }^{14} \mathrm{CO}_{2}$ production was less than $0.5 \%$ of the initially added toluene, sorbents were subjected to enzymatic hydrolysis to partially degrade the cellulose and hemicellulose. Selective hydrolysis of the organic matrix was intended to investigate whether the removal of cellulose and hemicellulose would enhance the bioavailability of sequestered toluene in paper materials. To evaluate the effect of lignin, toluene bioavailability tests were also conducted with whole NP, DNP, and DOP as well as with the lignins isolated from the three materials. OP was not tested because of its low lignin content (Table 4.10).

Sorbents. NP was collected from The News \& Observer Recycling Division (News \& Observer Publishing Co., Garner, NC). OP was collected from the NC State University recycling center. The preparation of degraded sorbents and sorbent characterization has been described (Wu et al. 2001). All sorbents were dried and ground to pass a 1-mm screen in a Thomas-Wiley laboratory mill and stored in a desiccator until use.

Chemicals and Reagents. All chemicals were reagent grade. ${ }^{14} \mathrm{C}$-toluene $(2.8$ $\mathrm{mCi} / \mathrm{mmol}$, 99\% purity) was purchased from Sigma-Aldrich Chemical Co. (St. Louis, $\mathrm{MO}$ ). One $\mathrm{mCi}{ }^{14} \mathrm{C}$-toluene was mixed with $10 \mathrm{~mL}$ non-labeled toluene (reagent grade) to make a stock solution with a final concentration of $120786 \mathrm{dpm} / \mu \mathrm{L}$. Stock solutions were stored at $-10^{\circ} \mathrm{C}$ until use.

Cellulase produced by Trichoderma reesei ( $T$. reesei) and hemicellulase produced by Aspergillus niger (A. niger) were purchased from Sigma-Aldrich Chemical Co. An enzyme stock solution was prepared by dissolving $0.045 \mathrm{~g}$ of cellulase and $0.09 \mathrm{~g}$ of hemicellulase in $15 \mathrm{~mL}$ of $50 \mathrm{mM} \mathrm{pH} 5$ citric acid buffer. The cellulase and hemicellulase activities in the stock solution at optimal $\mathrm{pH}$ and $37^{\circ} \mathrm{C}$ were 11.6 and 1.58 units, respectively, where cellulase and hemicellulase units are defined as $\mu$ mole of glucose produced/(hr. $\mathrm{mg}$ cellulase) and $\mu$ mole of D-galactose produced/(hr. $\mathrm{mg}$ hemicellulase), respectively. The optimal $\mathrm{pH}$ values for cellulase and hemicellulase are 
5.0 and 5.5, respectively. The stock solution was prepared just prior to use to prevent protein denaturation.

Bacterial Strains and Growth Conditions. $P p F 1$ was grown at $30 \pm 1{ }^{\circ} \mathrm{C}$ in medium containing $4.22 \mathrm{~g} \mathrm{KH}_{2} \mathrm{PO}_{4}, 3.37 \mathrm{~g} \mathrm{~K}_{2} \mathrm{HPO}_{4}, 0.05 \mathrm{~g} \mathrm{CaCl}_{2} \cdot 2 \mathrm{H}_{2} \mathrm{O}, 0.005 \mathrm{~g} \mathrm{FeCl}, 0.201 \mathrm{~g}$ $\mathrm{MgSO}_{4} \cdot 7 \mathrm{H}_{2} \mathrm{O}, 0.5 \mathrm{~g} \mathrm{NH}_{4} \mathrm{NO}_{3}, 0.01 \mathrm{~g}$ disodium EDTA, $1.43 \mathrm{mg} \mathrm{H}_{3} \mathrm{BO}_{3}, 0.32 \mathrm{mg}$ $\mathrm{ZnSO}_{4} \cdot \mathrm{H}_{2} \mathrm{O}, 0.1 \mathrm{mg} \mathrm{CoCl} 2 \cdot 4 \mathrm{H}_{2} \mathrm{O}, 0.08 \mathrm{mg} \mathrm{CuSO}{ }_{4} \cdot \mathrm{H}_{2} \mathrm{O}$ and $0.05 \mathrm{mg} \mathrm{Na}_{2} \mathrm{MoO}_{4} \cdot 2 \mathrm{H}_{2} \mathrm{O}$, per liter of deionized water. To prepare an inoculum for a bioavailability test, $25 \mathrm{~mL}$ of sterile medium was inoculated and $P p F 1$ was grown in an incubator shaker (150 rpm) with $0.12 \mathrm{mmol}$ toluene. After $24 \mathrm{hr}, 0.5 \mathrm{~mL}$ of the culture was transferred into $25 \mathrm{~mL}$ of fresh medium and incubated for an additional $24 \mathrm{hr}$. The cells were then washed twice with $50 \mathrm{mM} \mathrm{pH} 7$ phosphate buffer and resuspended to an optical density of 0.79 at 600 nm.

Optimization of Enzymatic Sorbent Hydrolysis. $\mathrm{PpF1}$ grows optimally at $\mathrm{pH} 7$ and $30^{\circ} \mathrm{C}$ in the presence of oxygen, which was provided by constant shaking. As described above, the $\mathrm{pH}$ optima for cellulase and hemicellulase are $\mathrm{pH} 5$ and 5.5, respectively. Thus, it was necessary to evaluate whether the enzymes could be used under conditions appropriate for $P p F 1$. In this study, the effect of $\mathrm{pH}$ was tested because it is difficult to adjust in the presence of strong phosphate buffer. The temperature was adjusted from the optimal temperature for $P p F 1$ to $37^{\circ} \mathrm{C}$ for enzymatic hydrolysis.

To evaluate the effect of $\mathrm{pH}$, the enzymatic hydrolysis was carried out in $160 \mathrm{~mL}$ glass ampoules, in which suspensions were continuously mixed with a magnetic stir bar (Kaya et al. 1996). Three gm of sorbent that had been sterilized by $2.2 \mathrm{Mrad}$ of $\gamma$-irradiation from a ${ }^{60} \mathrm{Co}$ source were mixed with $60 \mathrm{~mL}$ of $50 \mathrm{mM}$ pH 5 citric acid buffer or $\mathrm{pH} 7$ phosphate buffer depending on the target $\mathrm{pH}$. One $\mathrm{mL}$ of $3 \%$ sodium azide was added to prevent aerobic degradation of the sorbent and hydrolysis products. Three $\mathrm{mL}$ cellulase plus hemicellulase filter-sterile stock solution $(0.2 \mu \mathrm{m}$ HT Tuffryn membrane syringe filter, Ann Arbor, MI) was incubated with the sorbent/buffer mixture at $37^{\circ} \mathrm{C}$ at either $\mathrm{pH}$ 5 or 7 for about $100 \mathrm{~h}$. Solid samples without enzyme addition served as controls. 
Samples $(1.5 \mathrm{~mL})$ were removed periodically to measure the release of reducing sugars.

Preparation of Sorbents with Sequestered Toluene. Sorbents containing sequestered ${ }^{14} \mathrm{C}$-toluene were prepared by depleting the readily bioavailable toluene under conditions designed to promote toluene biodegradation. After toluene had been aged with sorbents for 1, 30 and 180 days, four replicate samples were inoculated with $3 \mathrm{~mL}$ of a suspension of $P p F 1$ to give $1.5 \times 10^{8}$ cells $/ \mathrm{mL}$. Bottles were sealed with a stainless steel Swagelok ${ }^{\mathrm{TM}}$ cap into which three stainless steel needles were welded (Fig. 4.4). Sterile glass vials were attached to the two long needles. One vial contained $2 \mathrm{~mL}$ of $2 \mathrm{~N} \mathrm{NaOH}$ to dissolve the evolved ${ }^{14} \mathrm{CO}_{2}$. The second vial contained $1 \mathrm{~mL}$ of $30 \%$ (v/v) $\mathrm{H}_{2} \mathrm{O}_{2}$ plus $0.5 \mathrm{~mL}$ of $0.5 \%$ (wt/wt) $\mathrm{FeCl}_{2}$ that acted as a catalyst to promote oxygen production from $\mathrm{H}_{2} \mathrm{O}_{2}$ to maintain aerobic conditions. The long needles were sealed with push button syringe valves to prevent volatilization losses. A Tedlar gasbag was attached to the short needle to prevent a pressure increase in the reactor system from excess $\mathrm{O}_{2}$. Samples were incubated at $30 \pm 1{ }^{\circ} \mathrm{C}$ in an incubator shaker (New Brunswick Scientific C24 Classic series, Edison, NJ) operated at $140 \mathrm{rpm} .{ }^{14} \mathrm{C}$-toluene biodegradation was quantified by measurement of ${ }^{14} \mathrm{CO}_{2}$ dissolved in the $\mathrm{NaOH}$ trap, the contents of which were removed at $0.2-2$ day intervals. Duplicate $0.5 \mathrm{~mL} \mathrm{NaOH}$ aliquots were mixed with $6 \mathrm{~mL}$ of Ultima Gold scintillation cocktail (Packard BioScience, Meriden, CT). Prior to scintillation counting, samples were refrigerated overnight to reduce chemiluminescence. Fresh $\mathrm{NaOH}$ was added after each sampling.

Enzyme Facilitated Bioavailability Test. To evaluate whether cellulose and hemicellulose hydrolysis would increase toluene bioavailability, hydrolytic enzymes were added to the sorbent containing toluene that remained once toluene degradation became negligible in bioavailability tests. After consumption of bioavailable toluene as described above, the $\mathrm{pH}$ of the sorbent/growth medium mixture was adjusted to 5 with 6 $\mathrm{N} \mathrm{HCl}$ to provide suitable conditions for enzymatic hydrolysis. Three $\mathrm{mL}$ of enzyme stock solution were then added to two of the four replicate bioavailability reactors while the remaining two served as enzyme-free controls. An autoclaved Teflon ${ }^{\mathrm{TM}}$-coated stirrer was added to the reactors aseptically. All samples were then incubated at $37^{\circ} \mathrm{C}$ while 
being stirred continuously. After $48 \mathrm{hr}$ of enzyme treatment, the $\mathrm{pH}$ of the sorbent/medium mixture was adjusted back to $\mathrm{pH} 7$ with $6 \mathrm{~N} \mathrm{NaOH}$. To evaluate the effect of enzymatic hydrolysis, samples were reinoculated with $3 \mathrm{~mL}$ of $P p F 1$ and toluene mineralization was again monitored by measuring ${ }^{14} \mathrm{CO}_{2}$ production.

Lignin Isolation. Lignins were isolated from NP, DNP and DOP by removing cellulose and hemicellulose with sulfuric acid (Petterson 1984). Ground sorbent (1g) was extracted with $150 \mathrm{~mL}$ of a $2: 1$ mixture of toluene/95\% ethanol for $20 \mathrm{~min}$ to remove lipophilic substances. The solvent extracted sorbents were then hydrolyzed with $10 \mathrm{~mL}$ of $72 \%$ (w/w) $\mathrm{H}_{2} \mathrm{SO}_{4}$. The hydrolyzed mixture was diluted with $300 \mathrm{~mL}$ deionized water and autoclaved for $60 \mathrm{~min}$ at $121^{\circ} \mathrm{C}$ and $103.4 \mathrm{Kpa}$. The mixture was filtered through a glass fiber filter (Whatman 934AH) and the collected lignin was rinsed continuously with deionized water. The lignin (NP-lignin, DNP-lignin, DOP-lignin) was then dried at $75^{\circ} \mathrm{C}$ and stored in a desiccator until use.

Reducing sugar measurement. Reducing sugars released during hydrolysis were measured by the dinitrosalicyclic acid (DNS) assay (Chaplin and Kennedy 1994). Samples were prepared by centrifugation at $16000 \times \mathrm{g}$ for $5 \mathrm{~min}$. To measure reducing sugars, $1.0 \mathrm{~mL}$ of the DNS reagent was mixed with $100 \mu \mathrm{L}$ sample and heated at $100^{\circ} \mathrm{C}$ for $10 \mathrm{~min}$. After rapid cooling to room temperature, the absorbance was measured at 570 $\mathrm{nm}$. A standard curve was prepared with $\alpha$-D-glucose.

Data Analysis. The extent of sorbed toluene mineralization was calculated from eqn. 1. Extent of mineralization $(\%)=\frac{P_{\text {sorbent }}-P_{\text {blank }}}{q} \times 100$

Where $P_{\text {sorbent }}$ and $P_{\text {blank }}$ represent ${ }^{14} \mathrm{CO}_{2}(\mathrm{dpm})$ production from samples containing sorbents and sorbent-free blanks that had the same aqueous-phase toluene concentration as the sorbent-containing samples after aging, and $q(\mathrm{dpm})$ corresponds to the amount of toluene present in a sorbent after aging. Thus, the extent of mineralization at the end of the bioavailability test was calculated based on the conversion of sorbed toluene to ${ }^{14} \mathrm{CO}_{2}$. 
Differences between treatments were evaluated by performing analyses of variance (ANOVA) ( $\mathrm{p}<0.05$ ). All statistical tests were performed by SAS 8.0 software (SAS Institute Inc., Cary, NC).

\section{Results and Discussion}

Optimization of Cellulose Hydrolysis. Initially, tests were conducted to identify suitable conditions for enzymatic hydrolysis. These tests were necessary to understand whether it would be possible to maintain one set of environmental conditions in a reactor that would allow for both biological activity of $P p F 1$ and enzyme activity. Enzyme activities were tested at $\mathrm{pH} 5$ and 7, which are the $\mathrm{pH}$ optima for cellulase activity (Geimba et al. 1999) and $P p F 1$, respectively. The $\mathrm{pH}$ optimum for hemicellulases (5.5) was slightly compromised because the sorbents contained less hemicellulose than cellulose. Sugar release was significantly higher at $\mathrm{pH} 5$ for all sorbents (Table 4.10).

Enzymatic sugar release exhibited an initial rapid phase and then declined as time elapsed (Fig 4.4). Possible explanations for the decline in enzyme activity include end product inhibition (Azevedo et al. 2002), substrate transformation (Puri 1984) and reduced substrate surface area. The major products of cellulose hydrolysis, cellubiose and glucose, can bind to endoglucanases and cellobiohydrolases and inhibit cellulase adsorption to the sorbent (Sharrock, 1988; Azevedo et al. 2002). Furthermore, cellubiose is reported to be a stronger inhibitor than glucose (Desai and Converse 1997). The cellulase used in this study, originating from $T$. reesei, is relatively deficient in $\beta$ glucosidase, a major component in cellulase that is responsible for the conversion of cellubiose to glucose (Ooshima et al. 1991). Thus, end product inhibition is one likely explanation for the decline in enzyme activity. Replacing the hydrolysate with end product-free buffer may have enhanced the extent of cellulose and hemicellulose hydrolysis in each sorbent by eliminating end product inhibition. However, hydrolysate replacement would have been impractical for assessing the effect of enzymatic hydrolysis on toluene bioavailability because any toluene that would have been released to the liquid phase would have been removed. Substrate transformation during hydrolysis would 
render sorbents also less susceptible to enzyme attack. The preferential degradation of the more reactive amorphous cellulose region leaves the sorbents enriched in crystalline cellulose, which is more resistant to further hydrolysis (Nazhad et al. 1995). Finally, enzymes must bind to the sorbent surface to act on cellulose, and the surface area available for enzyme sorption decreases during hydrolysis (Sinitsyn et al. 1989). The enzyme system for the degradation of hemicellulose is a broad group of synergistic enzymes (Puls and Poutanen 1989). Like most other polysaccharide-degrading enzymes, hemicellulase is also inhibited by the buildup of reaction products (Sreenath et al. 1999).

The data in Table 4.10 show a substantial decrease in enzyme activity when the $\mathrm{pH}$ was increased from 5 to 7 . Thus, it was necessary to adjust conditions for enzymatic hydrolysis in the sorbent/medium mixture to $\mathrm{pH} 5$. The extent of hydrolysis measured at $\mathrm{pH} 5$ and $37^{\circ} \mathrm{C}$ was judged to be sufficient to study the effect of cellulose and hemicellulose hydrolysis on toluene release.

Enzyme-Facilitated Bioavailability Tests. The effect of enzyme addition on the bioavailability of toluene sorbed to NP after aging times of 1,30 and 180 days is presented in Fig 4.5. (The effect of aging time on bioavailability was investigated by Chen (2003) and bioavailability was found to decrease with increasing aging time). In no case was there a statistically significant effect that could be attributed to the addition of cellullase and hemicellulase. Similar results for OP, DOP, and DNP are presented in Figs S4.6, S4.7, S4.8 (Supporting Information).

The presence of reducing sugars in bioavailability tests was further confirmed by the recovery of non-labeled $\mathrm{CO}_{2}$ in the base trap as measured by total inorganic carbon after reinoculation of $P p F 1$. Preliminary tests showed that $P p F 1$ does not have the ability to utilize cellulose and hemicellulose. Therefore, the non-labeled $\mathrm{CO}_{2}$ must have originated from the metabolism of reducing sugars released during hydrolysis. Although sorbent organic matter was effectively destroyed, ${ }^{14} \mathrm{CO}_{2}$ production from ${ }^{14} \mathrm{C}$-toluene was not enhanced. To confirm that ${ }^{14} \mathrm{C}$-toluene biodegradation was controlled by substrate availability and not by the loss of toluene degrading activity after preferential metabolism of easily degradable sugars, samples from bioavailability tests, collected after enzymatic 
hydrolysis, were analyzed by gas chromatography to determine the toluene concentration. The absence of detectable toluene (less than $4 \mu \mathrm{g} / \mathrm{L}$ ) confirmed that no toluene was released during sorbent hydrolysis (the calculated equilibrium aqueous toluene concentration should be $16521-54250 \mu \mathrm{g} / \mathrm{L}$ based on the published isotherm data for each sorbent (Wu et al. 2001)). This suggests that cellulose and hemicellulose do not control the sequestration of toluene for the tested sorbents.

Bioavailability of Toluene Sorbed to Purified Lignin. To evaluate the significance of lignin as the component of paper that controls sorption, bioavailability tests were conducted with NP, DNP, and DOP as well as with their extracted lignins. The mass of purified lignin used was equivalent to the mass of lignin in sorbents as calculated from reported lignin contents (Table 4.10). Both sorbent and lignin were spiked with the same amount of toluene prior to aging.

The fraction of the added toluene that was sorbed to each material after 1 day of aging is presented in Table 4.11. The difference in the fraction of toluene sorbed to paper materials and their respective lignins was statistically insignificant for NP $(p=0.92)$ and DNP $(p=0.84)$, indicating that extracted lignin could account for all of the sorption capacity in NP and DNP. Similar results were also observed after an aging time of 30 days with NP and NP-lignin (Table S4.1 in Supporting Information). The results of toluene bioavailability tests with NP, DNP, and their isolated lignins after 1 day aging are presented in Fig 4.6. Mineralization data are corrected for sorbent-free blanks so that the ${ }^{14} \mathrm{CO}_{2}$ production is based on the conversion of sorbed toluene. As illustrated in Fig 4.6, no statistically significant difference was observed for toluene bioavailability between NP and NP-lignin $(\mathrm{p}=0.99)$ or DNP and DNP-lignin $(\mathrm{p}=0.92)$. Similar results were also obtained for NP and NP-lignin after an aging time of 30 days (Fig S4.9 in Supporting Information).

Both the sorption capacity and bioavailability data suggest that lignin controls toluene sorption to and desorption from NP and DNP. In the mechanical pulping process used to produce NP, wood is fragmented and the treated fiber is released with little removal of 
lignin. Therefore, all major wood components, e.g. cellulose, hemicellose, lignin, are present in NP. In contrast, other organic matter fractions that can sorb toluene, such as crude protein and lipophilic extractives were present in relatively small amounts in NP (Table 4.10). The HOC sorption capacity of cellulose plus hemicellulose and lignin are explained by their structural differences. Although cellulose is completely insoluble in water, its molecules have a high affinity for water (Kuhad and Singh 1993). The polyhydroxyl structure together with other polar groups specifically interacts with water molecules via H-bonding. The strong interaction between the cellulose surface and water limits the interaction of cellulose with non-polar toluene molecules, leading to the relatively low sorptive capacity of cellulose. Hemicellulose has a similar molecular structure to cellulose although hemicellulose is composed of variable sugar subunits instead of repeating glucose subunits. Consequently, hemicellulose also exhibits little HOC sorption capacity (Mackay and Gschwend 2000). In contrast, the phenylpropane units of lignin produce a relatively hydrophobic region that has a higher affinity for HOCs than the hydrophilic structure of cellulose (Grathwohl 1990). The greater toluene sorption capacity of lignin can also be explained on the basis of solubility parameters, where sorbate/sorbent systems become more compatible as the difference between sorbate and sorbent solubility parameter decreases. The solubility parameters for toluene, cellulose and lignin are 8.8, 14.5-16.5 and 10-12 (cal/ $\left.\mathrm{cm}^{3}\right)^{1 / 2}$ respectively (Barton 1983). This is consistent with the higher toluene sorption capacity of lignin relative to cellulose because the solubility parameter difference between toluene and cellulose/hemicellulose is greater than that between toluene and lignin.

The partition coefficients $\left(\mathrm{K}_{\mathrm{p}}\right)$ describing toluene sorption to lignin are different among sorbents (Table 4.11). Such variation is consistent with previous reports, in which $\mathrm{K}_{\mathrm{p}}$ values of $97.2,141$ and $84.2 \mathrm{~mL} / \mathrm{g}$ have been reported for toluene sorption to Kraft pine lignin, organosolv lignin and alkali lignin, respectively (Garbarini and Lion 1986, Xing et al. 1994). This variation is not surprising as the composition of lignin varies depending on plant source, plant age, and isolation technique (Dence 1992). The ideal isolation method would allow the collection of chemically unmodified lignin that is free from contaminants. However, none of the existing methods fulfill this requirement (Tuomela et 
al. 2000). E.g.; the acid hydrolysis lignin extraction procedure used here does not completely remove cellulose/hemicellulose and proteins (Dence 1992). It should also be noted that this procedure modifies lignin present in plant species because ether linkages are cleaved and condensation reactions result (Wu and Argyropoulos 2003). For paper products, however, this structural modification may be less significant because of the prehydrolysis process employed prior to mechanical treatment of wood in the production of coarse fibers (Wallis 1971). Prehydrolysis involves treatment of wood under high pressure and temperature. Lignin solvolytic reactions take place by the action of water at elevated temperature. This treatment liberates components from the wood that render the solution mildly acidic and catalyze condensation reactions (Wallis 1971). After prehydrolysis, lignin becomes more stable under acidic conditions as $\alpha$ and $\beta$-ether linkages that are sensitive to acid condensed to form carbon-carbon bonds. As a result, the extracted NP- and DNP-lignins may have adequately represented the lignin originally present in NP and DNP.

There are two potential explanations for the lower sorptive capacity of DNP-lignin relative to NP-lignin. First, although lignin biodegradation is extremely slow under anaerobic conditions, some transformation and even mineralization has been reported (Benner et al 1984, Akin and Rigsby 1987, Akin and Benner 1988, Butler and Buckerfield, 1979, Dittmar and Lara 2001). The cleavage of aromatic rings in lignin could result in a lower toluene sorption capacity. However, analysis of NP-lignin and DNP-lignin by NMR showed no structural differences (data not shown), indicating lignin was either highly resistant to microbial attack or the biodegradation rate was extremely slow. Second, elemental analysis showed that DNP-lignin has a higher nitrogen content $(0.63 \%)$ relative to NP-lignin $(0.19 \%)$, and the $\mathrm{C} / \mathrm{N}$ ratio of NP-lignin decreased from 318 to 96 during biodegradation. The accumulation of nitrogen is likely a combination of microbial protein resynthesis during biodegradation and the incomplete removal of protein during the acid hydrolysis procedure (Dence 1992, Martens 2002). Difference in toluene sorption capacity between protein and lignin may therefore explain the decreased sorptive capacity of DNP-lignin relative to NP-lignin. 
In the case of DOP, the DOP lignin accounted for only $54 \%$ of the total DOP sorption capacity (Table 4.11). There are several explanations for this. First, hydrophobic sizing agents are applied to cellulose fibers during OP production to prevent water penetration. These agents include alkenyl succinic anhydrides (ASA) and alkyl ketene dimmers (AKD), all of which can be expected to contribute to the sorptive capacity of DOP because of their hydrophobicity. Second, the ratio of lipophilic extractives plus protein to lignin in DOP was much larger than in NP and DNP, suggesting that both lipophilic extractives (sizing agents, cell wall constituents) and protein contributed to the HOC sorption capacity of DOP. Similarly, because of the presence of crude protein and lipophilic extractives, bioavailability tests conducted with DOP composite showed a lower initial mineralization rate of sorbed toluene relative to DOP-lignin (Fig 4.6, p < 0.01). Also at the termination of the bioavailability test, the extent of sorbed toluene mineralization was lower for DOP compared to DOP-lignin. The contribution of crude protein to the decrease of toluene bioavailability in DOP is likely not significant because amorphous protein is plasticized by water at room temperature (Green et al. 1994, Sochava, 1997) and desorption of HOCs from the comparatively expanded, flexible organic matter in a rubbery polymer is fast (Xing and Pignatello 1997). In contrast, lipophilic extractives provide a hydrophobic environment in which nonionic organic compounds may strongly sorb. Sorbed toluene in DOP may have been less bioavailable than in DOP-lignin because of the strong hydrophobic interactions between lipophilic extractives and toluene. It has been reported that intermolecular interactions may be strong enough to resist exhaustive solvent extraction (Guthrie et al. 1999).

Environmental Significance. In addition to lignocellulosic materials, landfills contain plastics that will have considerably higher sorption capacities (Wu et al. 2001). Interestingly, older landfills that are most likely to contain HOCs and were likely built without engineered liners, will have lower concentrations of plastics due to their relatively recent development as a packaging material. Reinhart et al. (1990) reported that increases in sorbent hydrophobicity as a result of biopolymer degradation had little effect on $\mathrm{K}_{\mathrm{oc}}$ for sorption of HOCs to relatively nonpolar refuse, suggesting that landfill leachate HOC concentrations could increase over time due to the loss of sorbent organic 
matter. For a landfill where paper waste dominates, however, the biodegradation of cellulose and hemicellulose should not affect the overall sorptive capacity given the persistence of lignin and the presence of resynthesized lipids and proteins that have higher affinity for HOCs. Thus, where paper waste is dominant, HOC concentrations in leachate can be expected to decrease with time.

\section{Acknowledgments}

Although the research described in this article was funded by the U.S. EPA, it has not been subjected to the Agency's peer and administrative review and therefore may not necessarily reflect the views of the Agency; no official endorsement should be inferred. We thank Dr. Mike Hyman in the Department of Microbiology for providing toluenedegrading bacteria, experimental facilities and much constructive advice; Ms. Lixia Chen and Dr. Mark Nanny in Oklahoma University for NMR analysis of NP- and DNP-lignin, Mr. Jerry Wicks in the Department of Nuclear Engineering for sterilization of solid samples and Dr. Hou Min Chang in the Department of Wood and Paper Science for many helpful discussions.

\section{Literature Cited}

(1) US EPA Municipal Solid Waste in the United States: 2000 Facts and Figures. EPA530-R-02-001. Office of Solid Waste. U.S. EPA: Washington, DC. 2002.

(2) US EPA National survey of solid waste (municipal) landfill facilities. EPA/530-SW88-034. Office of Solid Waste and Emergency Response, US Environmental Protection Agency, Washington, D.C. 1988.

(3) US EPA http://www.epa.gov/superfund/sites/query/queryhtm/nplfin1.htm accessed Mar. 2003.

(4) Hilger, H. H.; Barlaz, M. A. Anaerobic Decomposition of Refuse in Landfills and Methane Oxidation in Landfill Cover Soils; In Manual of Environmental Microbiology, $2^{\text {nd }}$ Edn. Am. Soc. Microbiol: Washington, DC, 2001; pp. 696-718.

(4) Wang, Y. S.; Barlaz, M. A. Anaerobic biodegradability of alkylbenzenes and phenols by landfillderived microorganisms. FEMS Microbiol. Ecol. 1998, 25, 405-418.

(5) Ejlertsson J.; Meyerson U.; Svensson B. H. Anaerobic degradation of phthalic acid esters during digestion of municipal solid waste under landfilling conditions. Biodegradation. 1996, 7, 345-352.

(6) Jonsson S.; Ejlertsson, J.; Ledin, A.; Mersiowsky, I.; Svensson, B. H. Mono- and diesters from ophthalic acid in leachates from different European landfills. Water Res. 2003, 37, 609-617. 
(7) Kromann, A.; Christensen, T. H. Degradability of organic chemicals in a landfill environment studied by in situ and laboratory leachate reactors. Waste Manage. Res. 1998, 16, 437-445.

(8) Alexander, M. How toxic are toxic chemicals in soil. Environ. Sci. Technol. 1995, 29, 2713-2717.

(9) Luthy, R. G.; Aiken, G. R.; Brusseau, M. L.; Cunninghan, S. D.; Gschwend, P. M.; Pignatello, J. J.; Reinhard, M.; Trainan, S. J.; Weber, W. J. Jr.; Westall, J. C. Sequestration of hydrophobic organic contaminants by geosorbents. Environ. Sci. Technol. 1997, 31, 3341-3347.

(10) Stinson, J. A.; Ham, R. K. Effect of lignin on the anaerobic decomposition of cellulose as determined through the use of a biochemical methane potential method. Environ. Sci. Technol. 1995, 29, 2305-2310.

(11) Eleazer, W. E.; Odle, W. S.; Wang, Y. S.; Barlaz, M. A. Biodegradability of municipal solid waste components in laboratory-scale landfills. Environ. Sci. Technol. 31, 911-917.

(12) Pichler, M.; Kögel-Knabner, I. Chemolytic analysis of organic matter during aerobic and anaerobic treatment of municipal solid waste. J. Environ. Qual. 2000, 29, 1337-1344.

(13) Tong, M.; Smith, L. H.; McCarty, P. L. Methane fermentation of selected lignocellulosic materials. Biomass. 21, 239-255.

(14) Tuomela, M.; Vikman, M.; Hatakka, A.; Itävaara, M. Biodegradation of lignin in a compost environment: a review. Bioresource Technol. 2000, 72, 169-183.

(15) Garbarini, D. R.; Lion, L.W. Influence of the nature of soil organics on the sorption of toluene and trichloroethylene. Environ. Sci. Technol. 1986, 20, 1263-1269.

(16) Xing, B.; McGill, W. B.; Dudas, M. J. Sorption of benzene, toluene, and o-xylene by collagen compared with non-protein organic sorbents. Can. J. Soil Sci. 1994, 74, 465-469.

(17) Torrents, A.; Jayasundera, S.; Schmidt, W. Influence of the polarity of organic matter on the sorption of acetamide pesticides. J. Agric. Food Chem. 1997, 45, 3320-3325.

(18) Xing, B.; Pignatello, J. J.; Gigliotti, B. Competitive sorption between atrazine and other organic compounds in soils and model sorbents. Environ. Sci. Technol. 1996, 30, 2432-2440.

(19) Mackay, A. A.; Gschwend, P. M. Sorption of monoaromatic hydrocarbons to wood. Environ. Sci. Technol. 2000, 34, 839-845.

(20) Severtson, S. J.; Banerjee, S. Sorption of chlorophenols to wood pulp. Environ. Sci. Technol. 1996, 30, 1961-1969.

(21) Christensen, T. H.; Kjeldsen, P.; Albrechtsen, H. J.; Heron, G.; Nielsen, P. H.; Bjerg, P. L.; Holm, P. E. Attenuation of landfill leachate pollutants in aquifers. Crit. Rev. Environ. Sci. Technol. 1994, 24, 119202.

(22) Wu, B. Y.; Taylor, C. M.; Knappe, D. R. U.; Nanny, M. A.; Barlaz, M. A. Factors controlling alkylbenzene sorption to municipal solid waste. Environ. Sci. Technol. 2001, 35, 4569-4576.

(23) Kaya, F.; Heitmann, J. A.; Joyce, T. W. Deactivation of cellulase and hemicellulase in high shear field. 
Cell. Chem. Technol. 1996, 30, 49-56.

(24) Pettersen, R. C. The Chemical Composition of Wood, In Advance in Chemistry Series 207: The Chemistry of Solid Wood, Rowell, R., Ed., American Chemical Society:, Washington, DC, 1984; pp 57126.

(25) Chaplin, M. F.; Kennedy, J. F. Carbohydrate analysis: a practical approach, ILR Press, Oxford, U. K., 1994.

(26) Geimba, M. P.; Riffel, A.; Gaostini, V.; Brandelli, A. Characterization of cellulose-hydrolysing enzymes from the fungus Bipolaris sorokiniana. J. Sci. Food Agric. 1999, 79, 1849-1854.

(27) Azevedo, H.; Bishop, D.; Cavaco-Paulo, A. Possibility for recycling cellulases after use in cotton processing. Appl. Biochem. Biotechnol. 2002, 101, 61-75.

(28) Puri, V. P. Effect of crystallinity and degree of polymerization of cellulose on enzymatic saccharification. Biotechnol. Bioeng.. 1984, 26, 1219-1222.

(29) Sharrock, K. R. Cellulase assay methods: a review. J. Biochem. Biophys. Methods. 1988, 17, 81-106.

(30) Desai, S. G.; Converse, A. O. Substrate reactivity as a function of the extent of reaction in the enzymatic hydrolysis of lignocellulose. Biotechnol. Bioeng. 1997, 56, 650-655.

(31) Ooshima, H.; Kurakake, J.; Kato, J.; Harano, Y. Enzymatic activity of cellulose adsorbed on cellulose and its change during hydrolysis. Appl. Biochem. Biotechnol. 1991, 31, 253-266.

(32) Nazhad, M. M.; Ramos, L. P.; Paszner, L.; Saddler, J. N.; Structural constraints affecting the initial enzymatic hydrolysis of recycled paper. Enzyme Microb. Tech. 1995, 17, 68-74.

(33) Sinitsyn, A. P.; Mitkevich, O. V.; Gusakov, A. V. Decrease in reactivity and change of physicochemical parameters of cellulose in the course of enzymatic hydrolysis. Carbohydr. Polym. 1989, 10, 1-14.

(34) Puls. J.; Poutanen, K. Mechanisms of enzymatic hydrolysis of hemicelluloses (xylans) and procedures for determination of the enzyme activity involved. In Enzymes Systems for Lignocellulose Degradation. M. P. Coughlan ed, Elsevier, Amsterdam. 1989; pp 151-165.

(35) Sreenath, H. K.; Koegel, R. G.; Moldes, A. B.; Jeffries, R. W.; Staub, R. J. Enzymatic saccharification of alfalfa fiber after liquid hot water pretreatment. Process Biochemistry. 1999, 35, 33-41.

(36) Chen, Y. Ph.D. dissertation. The effect of aging on the bioavailability of toluene sorbed to municipal solid waste components. North Carolina State University. 2003.

(37) Kuhad, R. C.; Singh, A. Lignocellulose biotechnology: current and future prospects. Crit. Rev. Biotechnol. 1993, 13, 151-172.

(38) Grathwohl, P. Influence of organic-matter from soils and sediments from various origins on the sorption of some chlorinated aliphatic hydrocarbons-implications on Koc correlations. Environ. Sci. Technol. 1990, 24, 1687-1693.

(39) Barton, A. F. M. Handbook of solubility parameters and other cohesion parameters. CRC press. Boca 
Raton, FL. 1983.

(40) Dence, C. W. The determination of lignin. In Methods in Lignin Chemistry; Lin, S. Y., Dence, C. W., Eds.; Springer-Verlag: Heidelberg, 1992; pp 33-61.

(41) Wu, S. Argyropoulos, D. S. An improved method for isolating lignin in high yield and purity. J. Pulp. Paper Sci. 2003, 31-34.

(42) Wallis, A. F. A. Solvolysis by acids and bases. In Lignins: occurrence, formation, structure and reactions; Sarkanen, K. V. Ludwig, C. H. Eds.; John Wiley and Sons: New York, 1971; pp345-372.

(43) Benner, R.; Maccubbin, A. E.; Hodson, R. E. Anaerobic biodegradation of the lignin and polysaccharide components of lignocellulose and synthetic lignin by sediment microflora. Appl. Environ. Microbiol. 1984, 47, 998-1004.

(44) Akin, D. E.; Rigsby, L. L. Mixed fungal populations and lignocellulosic tissue degradation in the bovine rumen. Appl. Environ. Microbiol. 1987, 1987-1995.

(45) Akin, D. E.; Benner, R. Degradation of polysaccharides and lignin by ruminal bacteria and fungi. Appl. Environ. Microbiol. 1988, 1117-1125.

(46) Butler, J. H. A. and Buckerfield, J. C. Digestion of lignin by termites. Soil Biol. Biochem. 1979. 11, 507-513.

(47) Dittmar, T. and Lara, R. J. Molecular evidence for lignin degradation in sulfate-reducing mangrove sediments. Geochim. Cosmochim. Acta. 2001, 65, 1417-1428.

(48) Martens, D. A. Identification of phenolic acid composition of alkali-extracted plants and soils. Soil Sci. Soc. Am. J. 2002, 66, 1240-1248.

(49) Green, J. L.; Fan, J.; Angell, C. A. The protein-class analogy-some insights from homopeptide comparisons. J. Phys. Chem. 1994, 98, 13780-13790.

(50) Sochava, I. V. Heat capacity and thermodynamic characteristics of denaturation and glass transition of hydrated and anhydrous proteins. Biophys. Chem. 1997, 69, 31-41.

(51) Xing, B.; Pignatello, J. J. Dual-mode sorption of low-polarity compounds in glassy poly (vinyl chloride) and soil organic matter. Environ. Sci. Technol. 1997, 31, 792-799.

(52) Guthrie, E. A.; Bortiatynski, J. M.; van Heemst, J. D. H.; Richman, J. E.; Hardy, K. S.; Kovach, E. M.; Hatcher, P. G. Determination of $\left[{ }^{13} \mathrm{C}\right]$ pyrene sequestration in sediment microcosms using flash prolysisGC-MS and ${ }^{13}$ C NMR. Environ. Sci. Technol. 1999, 33, 119-125.

(53) Reinhart, D. R.; Gould, J.P.; Cross, W. H.; Pohland, F. G. Sorptive behavior of selected organic pollutants codisposed in a municipal landfill. In Hazardous Waste Management; Tedder, D. W., Pohland, F. G., Eds.; ACS Symposium Series 422; American Chemical Society: Washington, DC, 1990; pp292-310. 


\subsection{Figures and Tables of Manuscript 2}

\section{FIGURE 4.4 Bioavailability Reactor.}

Same as FIGURE 3.1.

TABLE 4.10 Sorbent Composition and Effect of pH on Enzymatic Hydrolysis of Biopolymers

\begin{tabular}{|c|c|c|c|c|c|c|c|}
\hline \multirow[b]{2}{*}{ sorbents } & \multicolumn{5}{|c|}{ sorbent characterization $(\%)^{a}$} & \multirow[b]{2}{*}{$\mathrm{pH} 5^{\mathrm{b}}$} & \multirow[b]{2}{*}{$\mathrm{pH} 7^{\mathrm{b}}$} \\
\hline & cellulose & hemicellulose & lignin & $\begin{array}{l}\text { lipophilic } \\
\text { extractives }\end{array}$ & crude protein & & \\
\hline office paper & 64.7 & 13.0 & 0.93 & 0.7 & 0.31 & $19.1(0.2)$ & $7.6(0.1)$ \\
\hline degraded office paper & 36.2 & 6.9 & 4.8 & 3.3 & 4.99 & $14.7(0.5)$ & $7.0(0.1)$ \\
\hline newsprint & 48.3 & 18.1 & 22.1 & 1.6 & 0.44 & $22.0(0.1)$ & $7.7(0.1)$ \\
\hline degraded newsprint & 35.1 & 16.0 & 32.3 & 1.4 & 3.74 & $8.5(0.8)$ & $4.0(0.3)$ \\
\hline
\end{tabular}

${ }^{\mathrm{a}}$ From Wu et al. (2001). ${ }^{\mathrm{b}}$ Data are the percentage of cellulose plus hemicellulose in sorbents converted to reducing sugars. Data are the averages of triplicate samples and values in parenthesis are the standard deviations. 


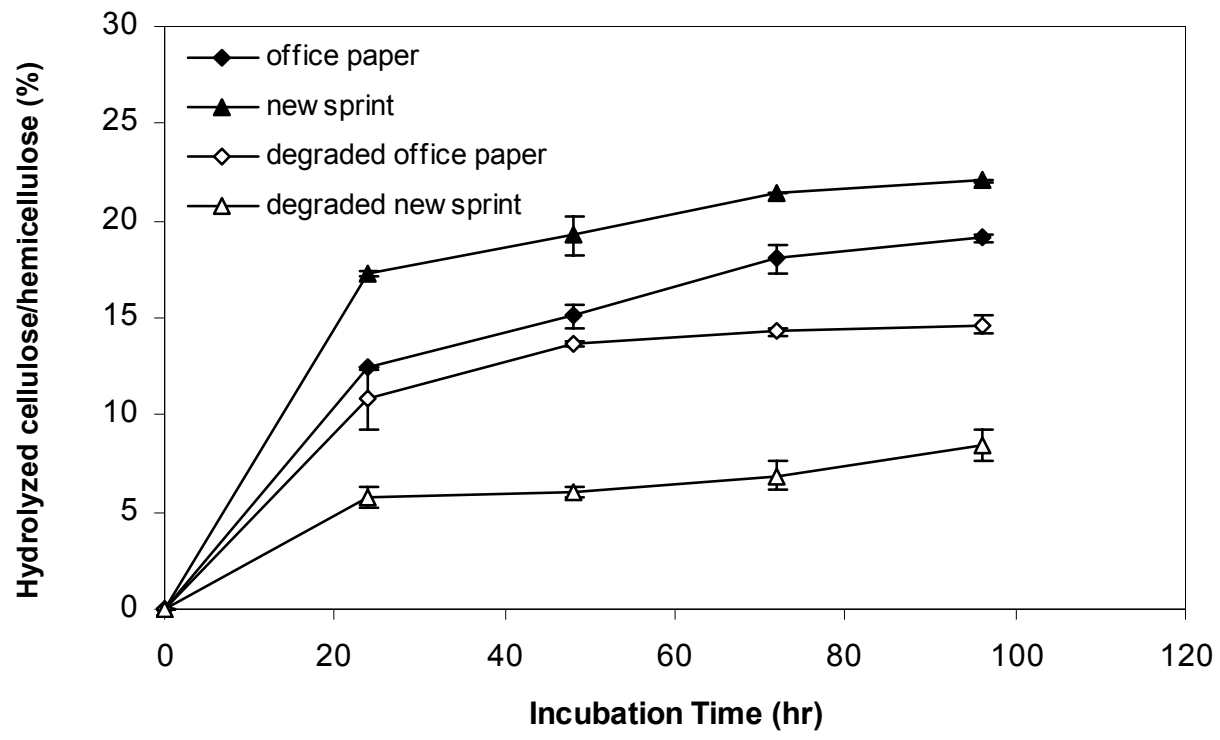

FIGURE 4.4 Comparison of enzymatic sorbent hydrolysis at $\mathrm{pH} 5$ and $37^{\circ} \mathrm{C}$

Data are averages of triplicate samples. Error bars correspond to standard deviation. 

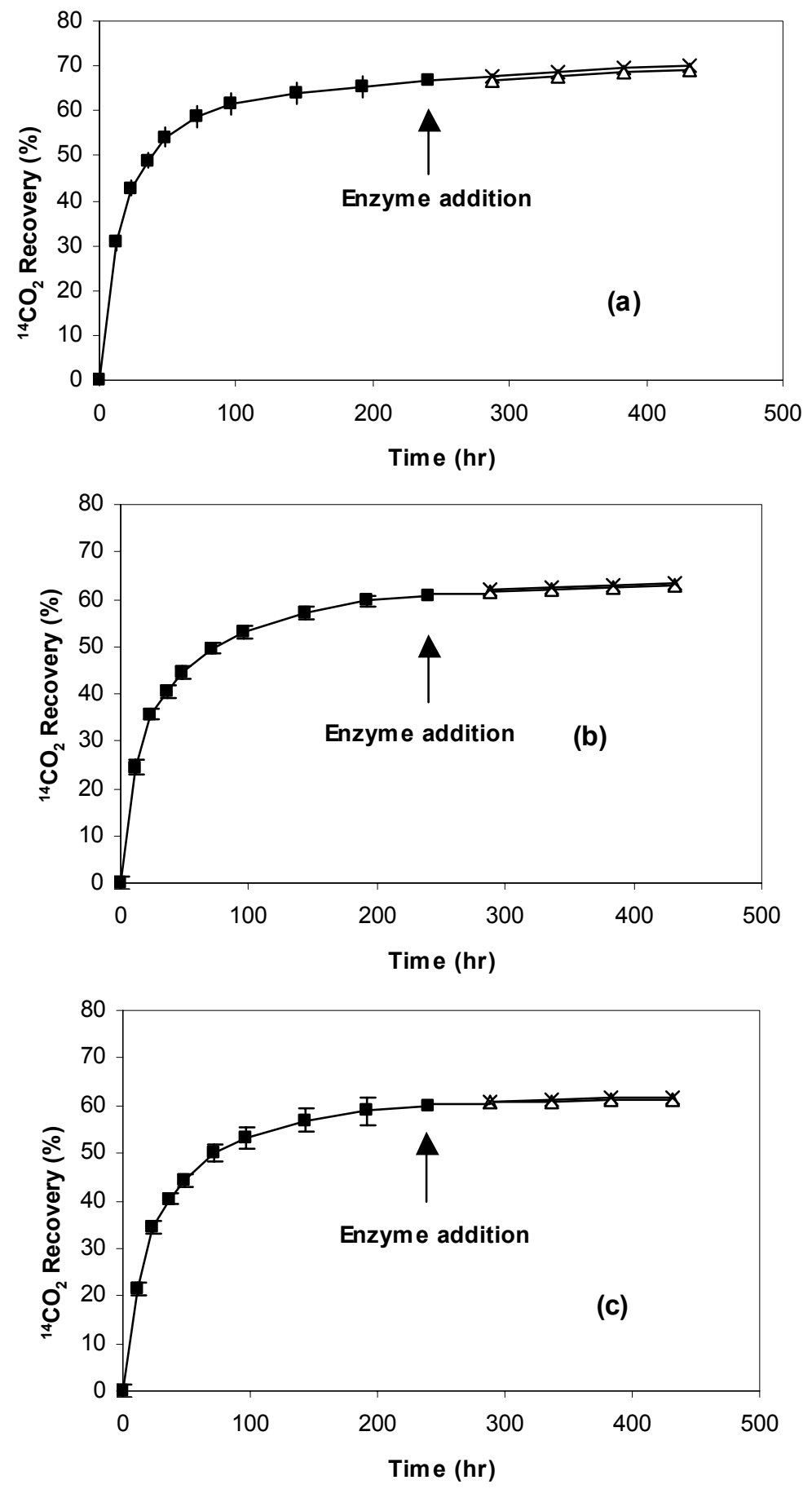

FIGURE 4.5 Effect of cellulase and hemicellulase addition on the bioavailability of toluene sorbed to newsprint aged for (a) 1 day, (b) 30 days and (c) 180 days.

Data are presented as the percentage of toluene added initially recovered as ${ }^{14} \mathrm{CO}_{2}$. Data before enzyme addition ( $(\mathbf{m})$ are averages of four replicates. Data with enzyme addition $(\Delta)$ and data without enzyme addition $(\times)$ are averages of duplicate samples. Error bars correspond to standard deviations. Some error bars are too small to view. 


\section{TABLE 4.11 Sorption of Toluene to MSW Components and Their Lignins (\%) ${ }^{\text {a, b }}$}

\begin{tabular}{cccc}
\hline \multirow{2}{*}{ sorbents } & \multicolumn{2}{c}{ toluene uptake $(\%)$} & $\mathrm{K}_{\mathrm{p}}(\mathrm{mL} / \mathrm{g})^{\mathrm{d}}$ \\
\cline { 2 - 3 } & whole sorbent $^{\mathrm{c}}$ & lignin extracted from sorbent & $82.84(1.05)$ \\
newsprint & $41.99(0.33)$ & $40.84(0.13)$ & $75.01(1.08)$ \\
degraded newsprint & $47.43(0.65)$ & $47.40(0.50)$ & $143.95(5.23)$ \\
degraded office paper & $37.81(0.24)$ & $20.62(1.53)$ & \\
\hline
\end{tabular}

${ }^{a}$ Data are the percentage of sorbed toluene based on total toluene added. ${ }^{b}$ Data are the averages of duplicate samples and values in parenthesis are the standard deviations. ${ }^{c}$ Mass of sorbents is similar to those used in bioavailability tests $(3 \mathrm{~g}) .{ }^{\mathrm{d}} \mathrm{K}_{\mathrm{p}}$ values were calculated for the sorption of toluene to extracted lignin. 

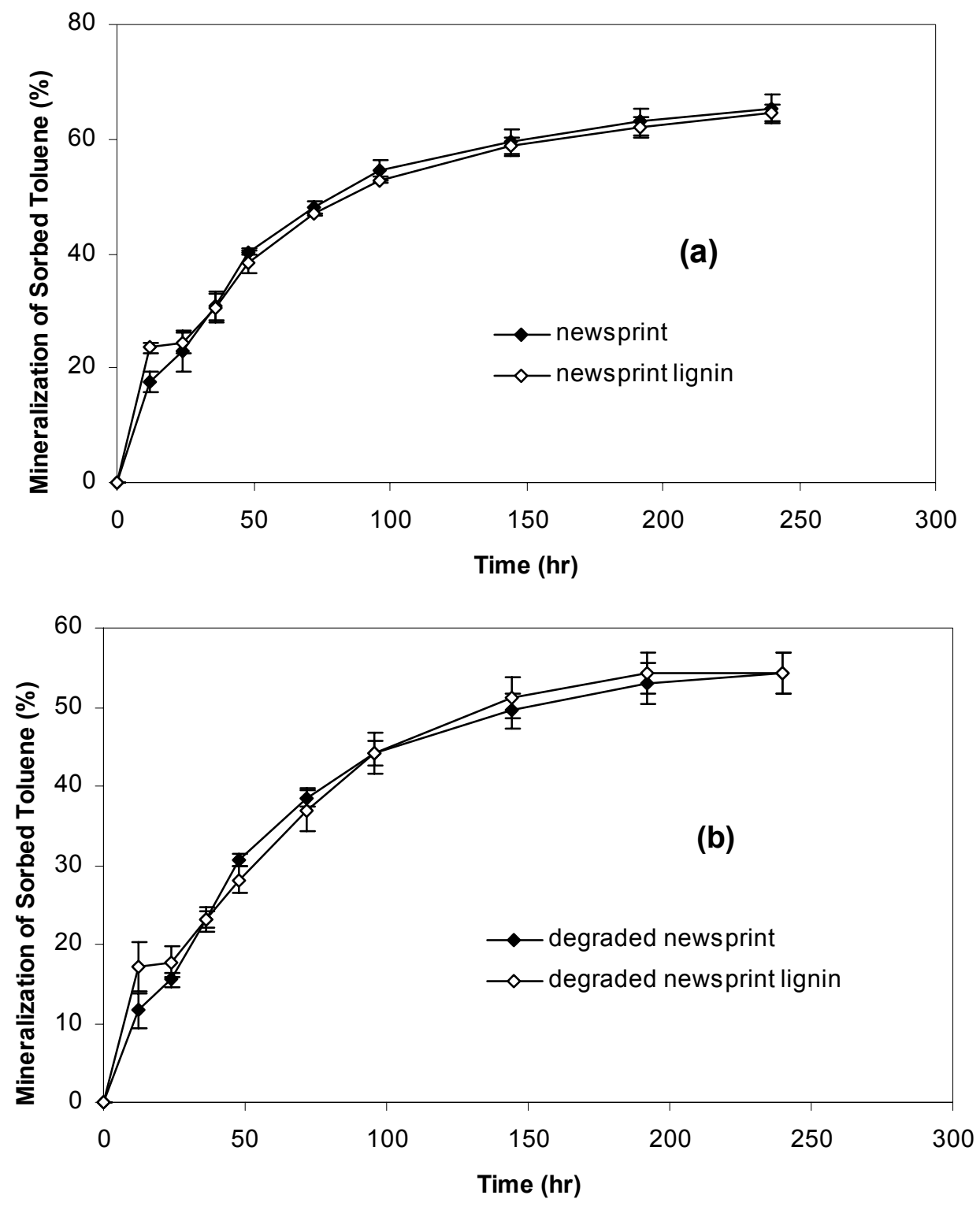


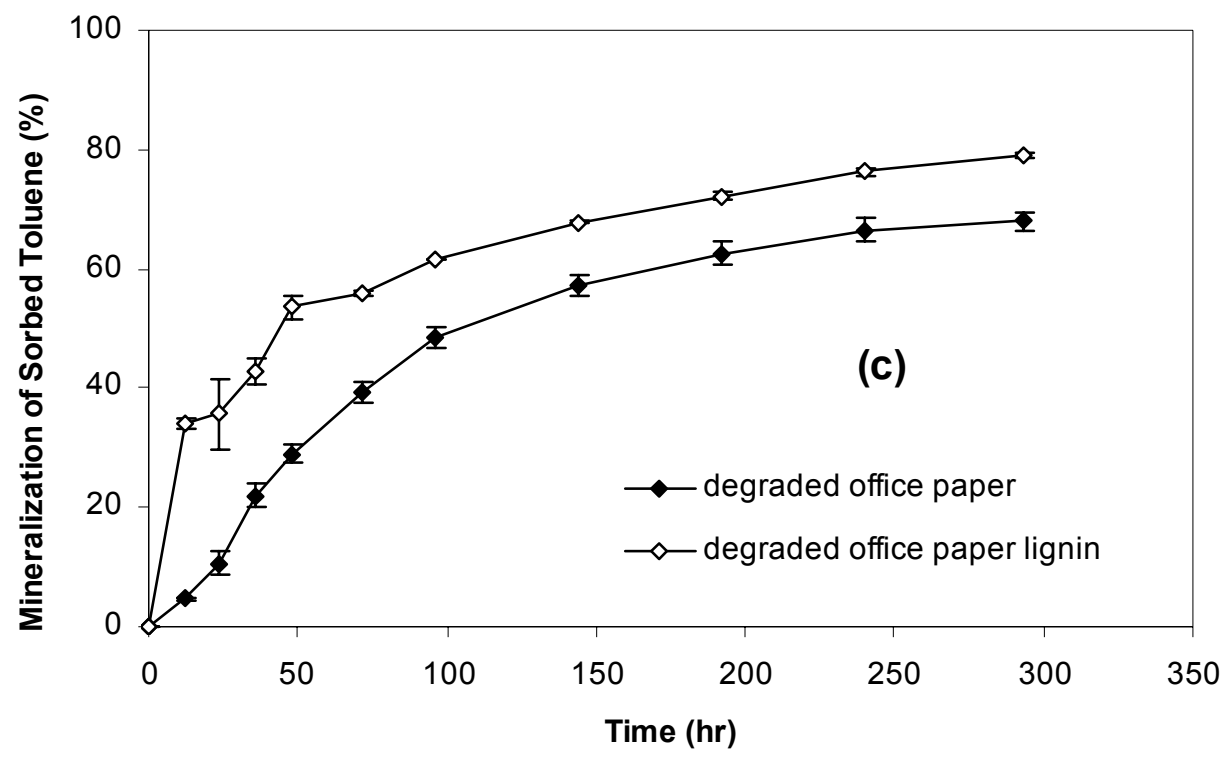

FIGURE 4.6 Bioavailability of toluene sorbed to (a) fresh newsprint, (b) degraded newsprint and (c) degraded office paper and isolated lignins of equivalent mass.

Mineralization data were calculated based on equation 1 and data are averages of three replicates. Error bars correspond to standard deviation. Some error bars are too small to view. 


\subsection{Supporting Information for Manuscript 2}
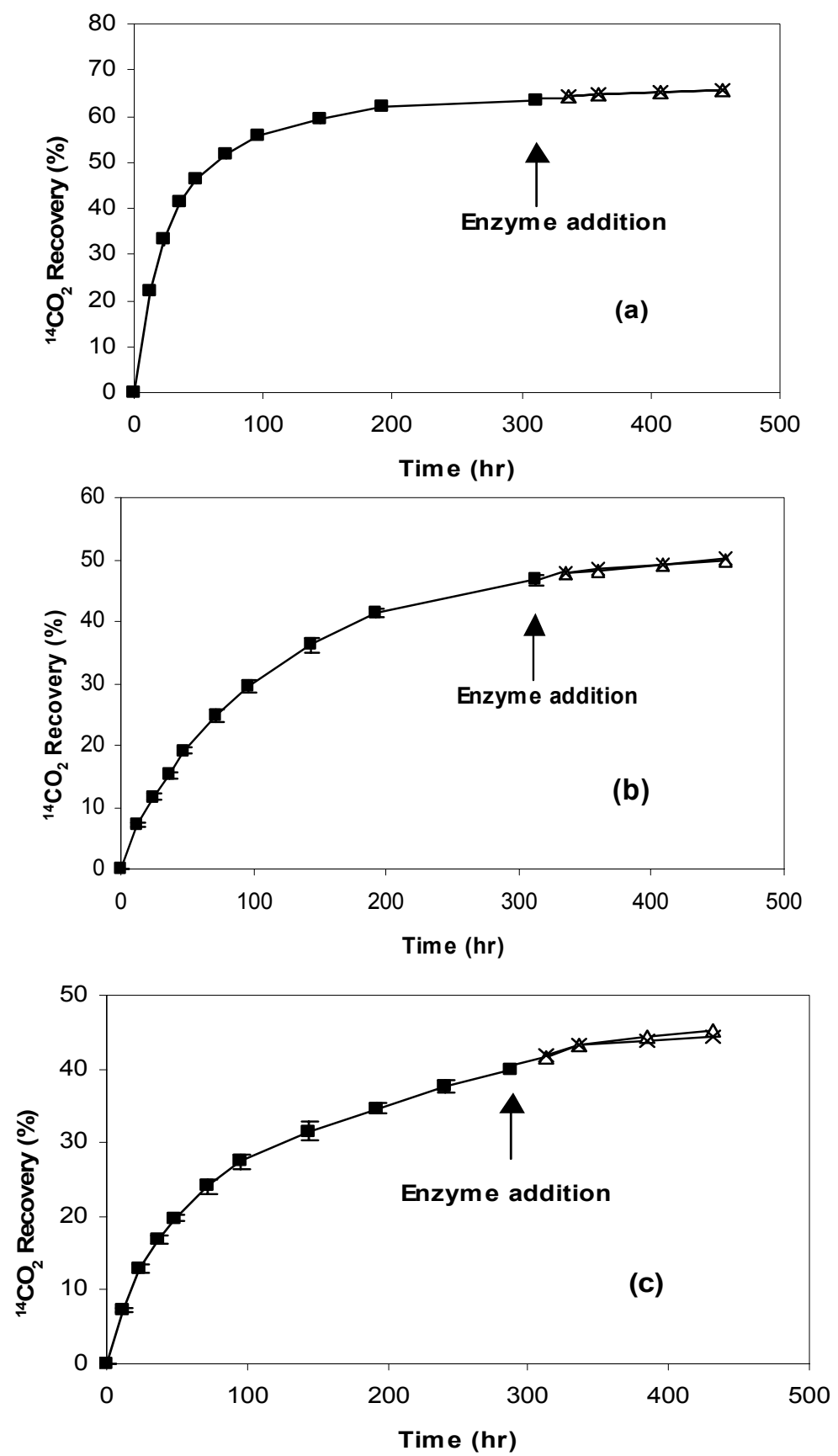

FIGURE S4.6 Effect of cellulase and hemicellulase addition on the bioavailability of toluene sorbed to office paper aged for (a) 1 day, (b) 30 days and (c) 180 days.

Data are presented as the percentage of toluene added initially recovered as ${ }^{14} \mathrm{CO}_{2}$. Data before enzyme addition ( $(\mathbf{m})$ are averages of four replicates. Data with enzyme addition $(\Delta)$ and data without enzyme addition $(x)$ are averages of duplicate samples. Error bars correspond to standard deviations. Some error bars are too small to view. 

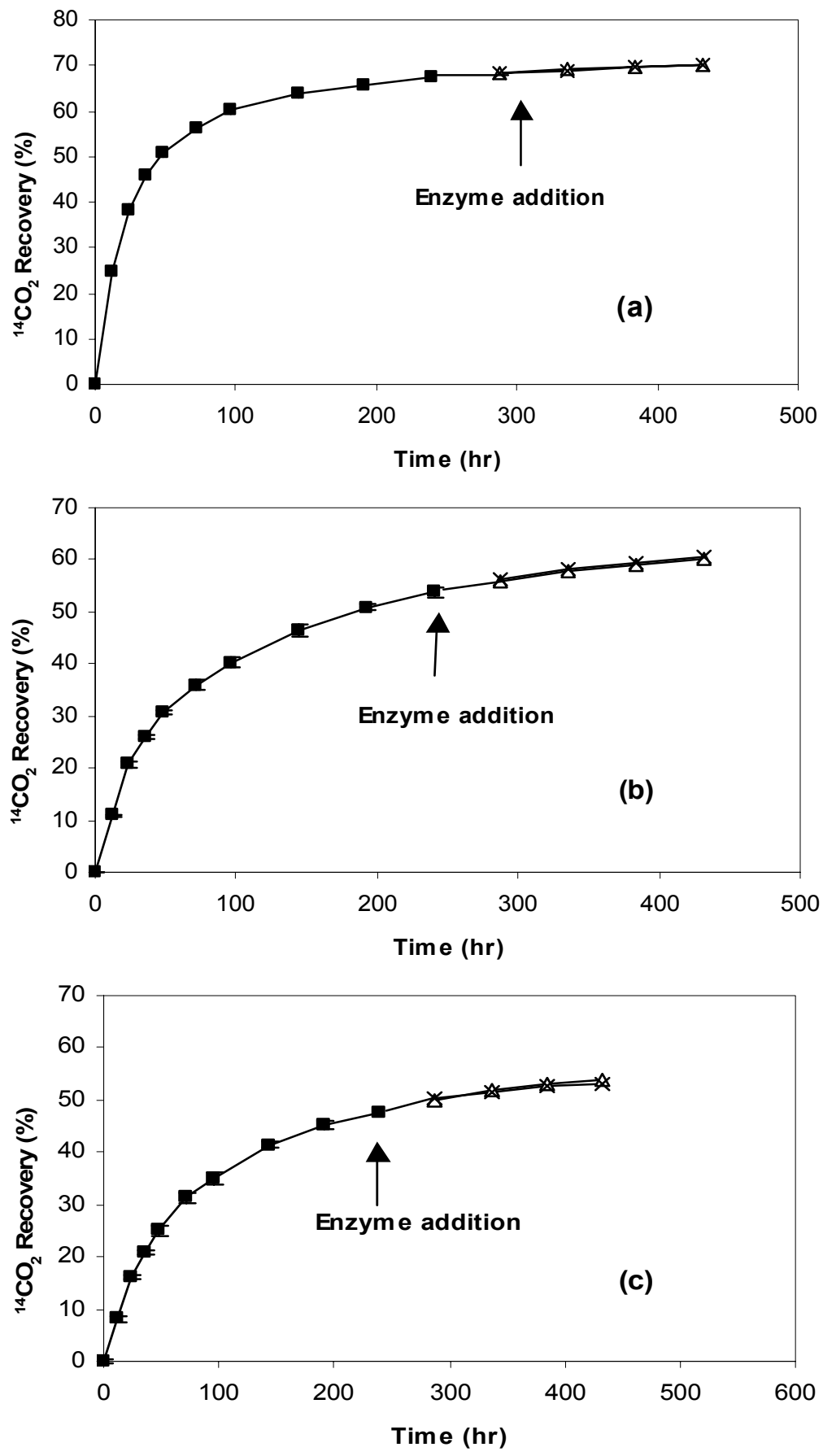

FIGURE S4.7 Effect of cellulase and hemicellulase addition on the bioavailability of toluene sorbed to degraded office paper aged for (a) 1 day, (b) 30 days and (c) 180 days.

Data are presented as the percentage of toluene added initially recovered as ${ }^{14} \mathrm{CO}_{2}$. Data before enzyme addition ( $(\mathbf{m})$ are averages of four replicates. Data with enzyme addition $(\Delta)$ and data without enzyme addition $(x)$ are averages of 
duplicate samples. Error bars correspond to standard deviations. Some error bars are too small to view.
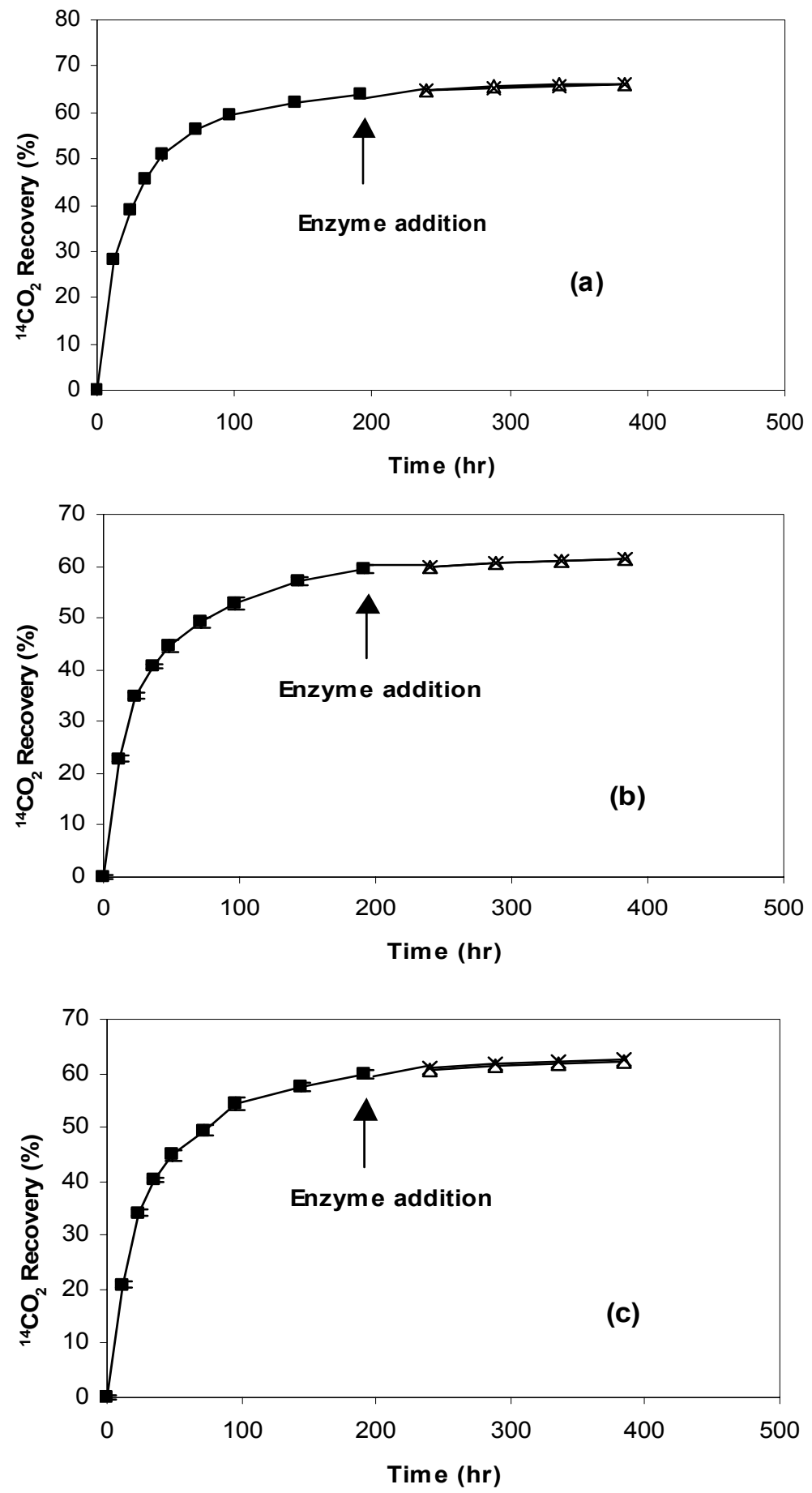

FIGURE S4.8 Effect of cellulase and hemicellulase addition on the bioavailability of toluene sorbed to degraded newsprint aged for (a) 1 day, (b) 30 days and (c) 180 days.

Data are presented as the percentage of toluene added initially recovered as ${ }^{14} \mathrm{CO}_{2}$. Data before enzyme addition ( $\left.\mathbf{\square}\right)$ 
are averages of four replicates. Data with enzyme addition $(\Delta)$ and data without enzyme addition $(\times)$ are averages of duplicate samples. Error bars correspond to standard deviations. Some error bars are too small to view.

TABLE S4.1 Sorption of Toluene to Newsprint and NP-Lignin after 30 days of aging (\%) ${ }^{\text {a, b }}$

\begin{tabular}{cccc}
\hline \multirow{2}{*}{ sorbents } & \multicolumn{2}{c}{ Toluene uptake (\%) } & \multirow{2}{*}{$\mathrm{K}_{\mathrm{p}}(\mathrm{mL} / \mathrm{g})^{\mathrm{d}}$} \\
\cline { 2 - 3 } & whole sorbent $^{\mathrm{c}}$ & lignin extracted from sorbent & \\
\hline newsprint & $46.33(0.83)$ & $46.08(1.31)$ & $102.67(5.39)$ \\
\hline
\end{tabular}

${ }^{a}$ Data are the percentage of sorbed toluene based on total toluene added. ${ }^{\mathrm{b}}$ Data are the averages of duplicate samples and values in parenthesis are the standard deviations. ${ }^{\mathrm{c}}$ Mass of newsprint is similar to those used in bioavailability tests $(3 \mathrm{~g}) .{ }^{\mathrm{d}} \mathrm{K}_{\mathrm{p}}$ values were calculated for the sorption of toluene by extracted lignin.

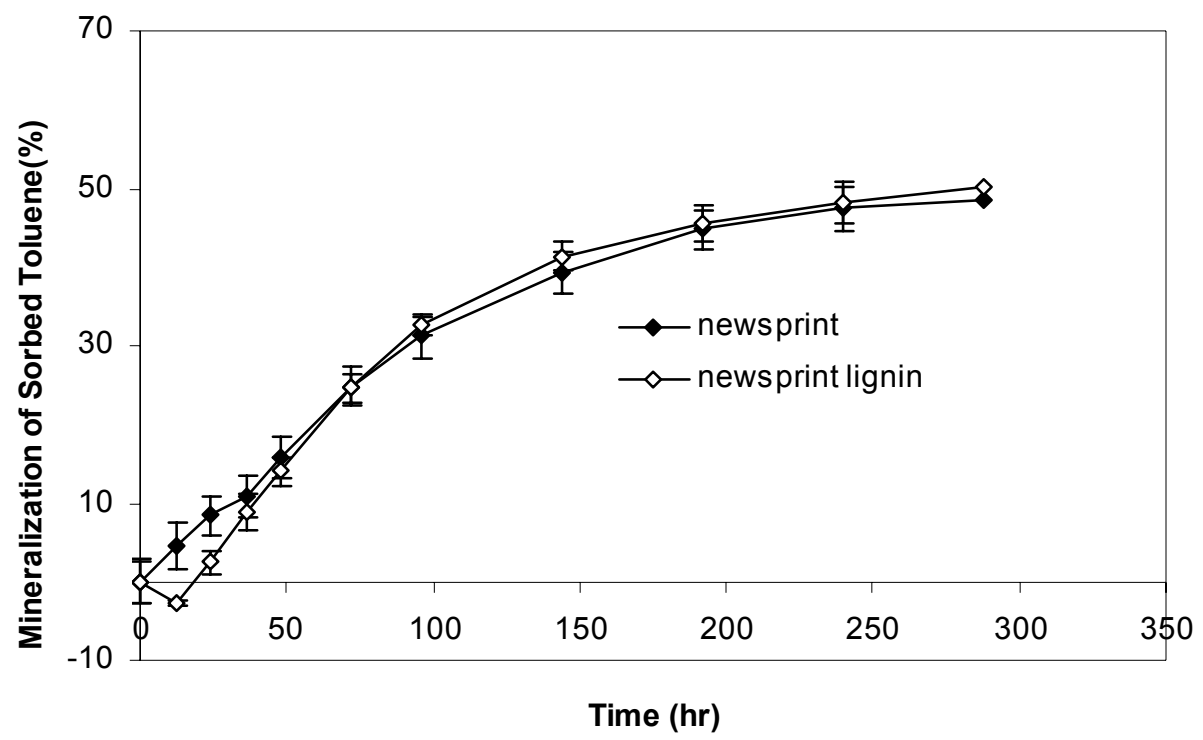

\section{FIGURE S4.9 Bioavailability of toluene aged for 30-d with fresh newsprint and isolated lignin of equivalent mass.}

Data were calculated based on equation 1 and data are averages of three replicates. Error bars correspond to standard deviations. Some error bars are too small to view. 


\section{Appendices}

\section{Appendix A Data of manuscript 1}

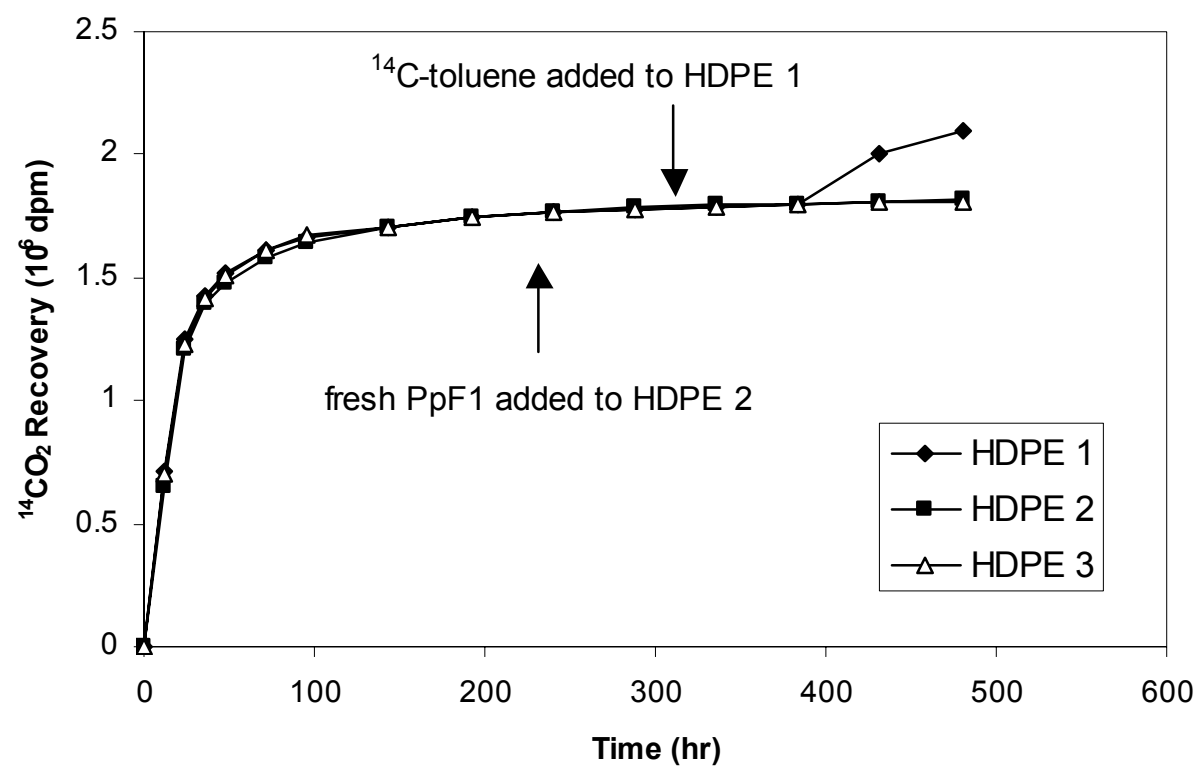

FIGURE A.1 Comparison of bioavailability of toluene sorbed to HDPE under different treatment

\section{TABLE A.1 Measurement of Liquid Phase ${ }^{14} \mathrm{C}$ Concentration by Different Treatments}

\begin{tabular}{ccc}
\hline & ${\text { treatment } 1^{\mathrm{a}, \mathrm{b}}}$ & ${\text { treatment } 2^{\mathrm{a}, \mathrm{c}}}$ \\
\hline sample 1 & 1810.56 & 1845.09 \\
sample 2 & 1814.38 & 1822.73 \\
\hline
\end{tabular}

${ }^{a}$ Concentrations are in $\mathrm{dpm} / 0.5 \mathrm{~mL}$ of liquid sample. ${ }^{\mathrm{b}}$ Treatment 1 is direct injection of samples with cells and particulates to scintillation cocktail. ${ }^{\mathrm{c}}$ Treatment 2 is the injection of cells and particulates to scintillation cocktail after cell lysis; cell lysis was performed by adding lysozyme followed by alternating freezing and thaw cells with $70^{\circ} \mathrm{C}$ dry ice and $65^{\circ} \mathrm{C}$ heat block respectively for three times. 
TABLE A.2 Bioavailability, Extraction and Combustion Data (dpm)

\begin{tabular}{|c|c|c|c|c|c|}
\hline PVC 1-d & & & & & \\
\hline Time (hr) & PVC 1 & PVC 2 & PVC 3 & blank 1 & blank 2 \\
\hline 0 & 0 & 0 & 0 & 0 & 0 \\
\hline 12 & 103183 & 100625 & 90898.5 & 120135 & 123934 \\
\hline 24 & 66177.5 & 58940.3 & 59800.3 & 31203.1 & 32885.5 \\
\hline 36 & 27822.4 & 32045.7 & 33359.5 & 8472.01 & 9029.85 \\
\hline 48 & 17638.1 & 21417 & 21079 & 4189.55 & 4149.52 \\
\hline 72 & 38157.1 & 40069.8 & 39426.9 & 5104 & 4266.93 \\
\hline 96 & 25632.7 & 27903 & 24772.2 & 3569.08 & 4691.12 \\
\hline 144 & 26812.4 & 28013.5 & 30829.2 & & \\
\hline 192 & 20660.6 & 19371 & 20098 & & \\
\hline 240 & 13077.2 & 10504.6 & 15366.05 & & \\
\hline 312 & 19557.8 & 15873.7 & 20939.3 & & \\
\hline 360 & 10044.8 & 9184.14 & 9521.45 & & \\
\hline 408 & 9500.17 & 7742.07 & 8959.56 & & \\
\hline 456 & 7653.94 & 6295.07 & 8038.6 & & \\
\hline 504 & 6263.15 & 6055.97 & 6316.98 & & \\
\hline after aging & 7377.42 & 6891.2 & 6761.57 & 6913.11 & 7009.39 \\
\hline liquid & 1810.56 & 1814.38 & 2442.05 & 6350.1 & 6165.81 \\
\hline after filtration & 369.54 & 362.52 & 348.35 & & \\
\hline BA 1 & 6531.97 & 6192.08 & 6018.24 & & \\
\hline BA 1vol (mL) & 12 & 12 & 12 & & \\
\hline BA 2 & 3606.99 & 3683.91 & 3278.98 & & \\
\hline BA 2 vol (mL) & 12 & 12 & 12 & & \\
\hline BA 3 & 1746.06 & 1869.64 & 1739.19 & & \\
\hline BA 3 vol (mL) & 15 & 15 & 15 & & \\
\hline BA 4 & 1936.66 & 1957.04 & 1951.02 & & \\
\hline BA 4 vol (mL) & 15 & 15 & 15 & & \\
\hline BA 5 & 1548.89 & 1447.66 & 1623.54 & & \\
\hline BA 5 vol (mL) & 15 & 15 & 15 & & \\
\hline BA 6 & 873.23 & 972.45 & 1033.99 & & \\
\hline BA 6 vol (mL) & 15 & 15 & 15 & & \\
\hline BA 7 & 523.65 & 472.06 & 523.11 & & \\
\hline BA 7 vol (mL) & 15 & 15 & 15 & & \\
\hline & & & & & \\
\hline & & & & & \\
\hline & & & & & \\
\hline & & & & & \\
\hline & & & & & \\
\hline & & & & & \\
\hline
\end{tabular}




\begin{tabular}{|c|c|c|c|c|c|}
\hline HDPE 1-d & & & & & \\
\hline Time (hr) & HDPE 1 & HDPE 2 & HDPE 3 & blank 1 & blank 2 \\
\hline 0 & 0 & 0 & 0 & 0 & 0 \\
\hline 12 & 187942 & 162640 & 175610 & 40850.3 & 40652 \\
\hline 24 & 145368 & 138912 & 137948 & 18774.3 & 18562.4 \\
\hline 36 & 43617.2 & 46945 & 46139.5 & 6194.89 & 6108.96 \\
\hline 48 & 21901.9 & 21205.2 & 23975.6 & 2329.87 & 2437.58 \\
\hline 72 & 24415.5 & 26484.3 & 25780.4 & & \\
\hline 96 & 13297.8 & 14872 & 15922.7 & & \\
\hline 144 & 8805.8 & 13974.5 & 8622.34 & & \\
\hline 192 & 9929.9 & 11326.3 & 8657.21 & & \\
\hline 240 & 7321.59 & 8932.75 & 7729.54 & & \\
\hline & & & & & \\
\hline after aging & 3536.43 & 3618.28 & 3756.55 & 3316.18 & 2952.16 \\
\hline liquid & 3673.32 & 3428.21 & 3670.52 & 2798.07 & 2486.65 \\
\hline after filtration & 490.59 & 472.29 & 516.39 & & \\
\hline BA 1 & 505.86 & 579.57 & 547.68 & & \\
\hline BA 1vol (mL) & 44.5 & 42.5 & 42 & & \\
\hline BA 2 & 385.63 & 379.96 & 323.81 & & \\
\hline BA 2 vol (mL) & 22 & 21 & 20 & & \\
\hline BA 3 & 275.63 & 287.66 & 294.85 & & \\
\hline BA 3 vol (mL) & 20 & 20 & 20 & & \\
\hline BA 4 & 173.22 & 166.24 & 159.63 & & \\
\hline BA 4 vol (mL) & 20 & 20 & 20 & & \\
\hline BA 5 & 111.26 & 99.32 & 103.22 & & \\
\hline BA 5 vol (mL) & 20 & 20 & 20 & & \\
\hline & & & & & \\
\hline & & & & & \\
\hline & & & & & \\
\hline & & & & & \\
\hline & & & & & \\
\hline
\end{tabular}




\begin{tabular}{|c|c|c|c|c|c|c|}
\hline $\begin{array}{c}\text { Office paper } \\
1-d\end{array}$ & & & & & & \\
\hline Time (hr) & OP 1 & OP 2 & OP 3 & OP 4 & blank 1 & blank 2 \\
\hline 0 & 0 & 0 & 0 & 0 & 0 & 0 \\
\hline 12 & 61213.1 & 48808.8 & 48433.4 & 56396.9 & 0 & 0 \\
\hline 24 & 29410.8 & 37854.2 & 40060.3 & 29081.2 & 47957.4 & 46743.9 \\
\hline 36 & 20305.6 & 18644 & 15897.3 & 21695.6 & 28306.9 & 27154.7 \\
\hline 48 & 13293.4 & 14865.7 & 14507.2 & 11054.9 & 18069.2 & 17532.4 \\
\hline 72 & 14530.9 & 15614.3 & 14727.9 & 12059.9 & 9724.44 & 11978.1 \\
\hline 120 & 10367.3 & 10783.3 & 10398.75 & 11128.9 & 9776.89 & 10015.3 \\
\hline 168 & 7794.21 & 7865.24 & 8158.75 & 9159.1 & 7940.24 & 8237.46 \\
\hline 216 & 4709.32 & 4976.88 & 6401.06 & 7979.87 & 3391.19 & 3645.46 \\
\hline 264 & 3926.98 & 4239.21 & 5529.65 & 4821.25 & & \\
\hline after aging & 6241.55 & 6242.9 & 6430.09 & 6304.85 & 6097.06 & 6044.75 \\
\hline liquid & 1018.33 & 1126.77 & & & 4974.35 & 4863.23 \\
\hline after filtration & 232.52 & 215.05 & & & & \\
\hline BA 1 & 218.7 & 176.97 & & & & \\
\hline BA 1 vol (mL) & 21 & 21.5 & & & & \\
\hline BA 2 & 1694.45 & 1824.31 & & & & \\
\hline BA 2 vol (mL) & 10 & 10.5 & & & & \\
\hline BA 3 & 190.28 & 224.81 & & & & \\
\hline BA 3 vol (mL) & 16.5 & 17 & & & & \\
\hline BA 4 & 141.28 & 186.99 & & & & \\
\hline BA 4 vol (mL) & 15 & 15 & & & & \\
\hline base tran 1 & & & & & & \\
\hline base trap 1 & 328.91 & 342.49 & & & & \\
\hline base trap 2 & 27.59 & 20.69 & & & & \\
\hline base trap 3 & 0 & 0 & & & & \\
\hline base trap 4 & 0 & 0 & & & & \\
\hline solid mass (g) & 3.8229 & 3.5381 & & & & \\
\hline & & & & & & \\
\hline & & & & & & \\
\hline & & & & & & \\
\hline & & & & & & \\
\hline & & & & & & \\
\hline & & & & & & \\
\hline & & & & & & \\
\hline
\end{tabular}




\begin{tabular}{|c|c|c|c|c|c|c|}
\hline $\begin{array}{c}\text { Degraded } \\
\text { Office paper } \\
1-d\end{array}$ & & & & & & \\
\hline Time (hr) & DOP 1 & DOP 2 & DOP 3 & DOP 4 & blank 1 & blank 2 \\
\hline 0 & 0 & 0 & 0 & 0 & 0 & 0 \\
\hline 12 & 141146 & 140055.5 & 140754 & 139357 & 90769.2 & 93772.6 \\
\hline 24 & 69450.1 & 78334 & 79302.5 & 77365.5 & 82042.9 & 83925 \\
\hline 36 & 43930.5 & 43814.55 & 44944.3 & 42684.8 & 28970.5 & 20456.7 \\
\hline 48 & 28993.3 & 27111.35 & 27079.9 & 27142.8 & 13184.5 & 14653.2 \\
\hline 72 & 30219.5 & 30612.8 & 31405.8 & 29819.8 & 10423.9 & 9938.4 \\
\hline 120 & 21271.1 & 20607.25 & 20543.8 & 20670.7 & 7342.99 & 6478.51 \\
\hline 168 & 20118 & 20389.85 & 20551.5 & 20228.2 & 4323.14 & 4696.7 \\
\hline 216 & 10842.2 & 12660.65 & 11658.1 & 13663.2 & & \\
\hline 264 & 8392.46 & 8969.28 & 8848.57 & 9089.99 & & \\
\hline after aging & 9450.71 & 9369.81 & 9397.35 & 9434.49 & 9434.45 & 9443.24 \\
\hline liquid & 1858.74 & 1783.97 & & & 8469.28 & 8423.55 \\
\hline after filtration & 409.16 & 414.55 & & & & \\
\hline BA 1 & 613.87 & 625.66 & & base 1 & 288.17 & 302.28 \\
\hline BA 1 vol (mL) & 15 & 16.5 & & base 1 vol & 24 & 23.5 \\
\hline BA 2 & 2409.44 & 2336.95 & & base 2 & 230.54 & 247.66 \\
\hline BA 2 vol (mL) & 18.5 & 17.5 & & base 2 vol & 28 & 29 \\
\hline BA 3 & 433.3 & 419.66 & & base 3 & 191.88 & 210.55 \\
\hline BA 3 vol (mL) & 30 & 29.6 & & base 3 vol & 28 & 28.5 \\
\hline BA 4 & 190.48 & 250.14 & & base 4 & 131.56 & 162.13 \\
\hline BA 4 vol (mL) & 22 & 24 & & base 4 vol & 288.17 & 302.28 \\
\hline BA 5 & 106.98 & 154.41 & & & & \\
\hline BA 5 vol (mL) & 20 & 21.5 & & & & \\
\hline HA & 0 & 0 & & & & \\
\hline HA vol (mL) & 0 & 0 & & & & \\
\hline $\mathrm{NH}$ & 71.82 & 83.3 & & & & \\
\hline NH vol (mL) & 90 & 89 & & & & \\
\hline FA & 152.16 & 167.4 & & & & \\
\hline FA vol (mL) & 110 & 120 & & & & \\
\hline & & & & & & \\
\hline base trap 1 & 354.64 & 387.73 & & & & \\
\hline base trap 2 & 5.04 & 19.22 & & & & \\
\hline base trap 3 & 0.9 & 0 & & & & \\
\hline base trap 4 & 0 & 0 & & & & \\
\hline solid mass (g) & 5.9741 & 5.8793 & & & & \\
\hline & & & & & & \\
\hline
\end{tabular}




\begin{tabular}{|c|c|c|c|c|c|c|}
\hline Newsprint 1-d & & & & & & \\
\hline Time (hr) & NP 1 & NP 2 & NP 3 & NP 4 & blank 1 & blank 2 \\
\hline 0 & 0 & 0 & 0 & 0 & 0 & 0 \\
\hline 12 & 166631 & 171183 & 176012 & 175487 & 125099 & 129978 \\
\hline 24 & 67416.6 & 60267.8 & 70660.6 & 76671.1 & 56611.6 & 57680.6 \\
\hline 36 & 35795.1 & 34738.1 & 37028.6 & 31639.2 & 14269.7 & 12823.89 \\
\hline 48 & 39486.1 & 24001 & 27197.1 & 23627.5 & 6659.86 & 6853.24 \\
\hline 72 & 27118 & 22740.5 & 29615.8 & 24227.2 & 6443.939 & 6904.872 \\
\hline 120 & 16498.6 & 16549.9 & 19375 & 14432.2 & & \\
\hline 168 & 14010.4 & 12824.2 & 13691.4 & 12158.6 & & \\
\hline 216 & 8879.2 & 8248.95 & 8623.64 & 8287.09 & & \\
\hline 264 & 5942.15 & 6237.55 & 6058.79 & 6014.77 & & \\
\hline after aging & 8795.11 & 8743.03 & 8843.67 & 8736.71 & 9023.72 & 9110.36 \\
\hline liquid & 1335.06 & 409.16 & & & 7963.42 & 8148.22 \\
\hline after filtration & 1451.38 & 414.55 & & & & \\
\hline BA 1 & 1232.97 & 1416.2 & & base 1 & 523.85 & 632.26 \\
\hline BA 1 vol (mL) & 18 & 16.5 & & base 1 vol & 30 & 30 \\
\hline BA 2 & 451.5 & 557.14 & & base 2 & 489.65 & 391.53 \\
\hline BA 2 vol (mL) & 27 & 26.5 & & base 2 vol & 25 & 24 \\
\hline BA 3 & 395.97 & 331.86 & & base 3 & 410.39 & 304.88 \\
\hline BA 3 vol (mL) & 25.5 & 25 & & base 3 vol & 26 & 24 \\
\hline BA 4 & 293.55 & 284.75 & & base 4 & 223.12 & 198.69 \\
\hline BA 4 vol (mL) & 25.5 & 24.5 & & base 4 vol & 25.5 & 26 \\
\hline & & & & & & \\
\hline & & & & & & \\
\hline HA & 1214.2 & 1232.95 & & & & \\
\hline HA vol (mL) & 15 & 15 & & & & \\
\hline $\mathrm{NH}$ & 138.35 & 127.19 & & & & \\
\hline NH vol (mL) & 104 & 102 & & & & \\
\hline FA & 160.09 & 179.22 & & & & \\
\hline FA vol (mL) & 92 & 92 & & & & \\
\hline & & & & & & \\
\hline base trap 1 & 141.53 & 193.65 & & & & \\
\hline base trap 2 & 70.49 & 78.94 & & & & \\
\hline base trap 3 & 0.61 & 2.81 & & & & \\
\hline base trap 4 & 0 & 0 & & & & \\
\hline solid mass (g) & 5.7102 & 5.5027 & & & & \\
\hline & & & & & & \\
\hline
\end{tabular}




\begin{tabular}{|c|c|c|c|c|c|c|}
\hline $\begin{array}{c}\text { Degraded } \\
\text { newsprint } 1-\mathrm{d}\end{array}$ & & & & & & \\
\hline Time (hr) & DNP 1 & DNP 2 & DNP 3 & DNP 4 & blank 1 & blank 2 \\
\hline 0 & 0 & 0 & 0 & 0 & 0 & 0 \\
\hline 12 & 158963 & 166895 & 150594 & 158744.5 & 120096 & 128125.2 \\
\hline 24 & 66373.7 & 55863.3 & 68101.2 & 62983 & 55951.3 & 47505.4 \\
\hline 36 & 34408.6 & 41392 & 38273.9 & 39895 & 15596.4 & 16243.52 \\
\hline 48 & 30008 & 27100.3 & 28706.9 & 27913 & 5830.94 & 5158.3 \\
\hline 72 & 30566.5 & 33988.9 & 31445.3 & 32767 & 8624.39 & 8924.23 \\
\hline 120 & 15108.8 & 17182.84 & 16308 & 19745 & & \\
\hline 168 & 13700.4 & 18399.6 & 14306 & 16753 & & \\
\hline 216 & 9177.33 & 11841.9 & 9540.81 & 10791 & & \\
\hline after aging & 8014.79 & 7907.26 & 7947.3 & 8234.49 & 8099.53 & 8103.62 \\
\hline liquid & 2260.67 & 2295.38 & & & 7211.42 & 7321.96 \\
\hline after filtration & 637.31 & 552.07 & & & & \\
\hline BA 1 & 980.52 & 717.14 & & base 1 & 843.12 & 795.94 \\
\hline BA 1 vol $(\mathrm{mL})$ & 3 & 5 & & base 1 vol & 19.5 & 19.5 \\
\hline BA 2 & 2090.08 & 1796.82 & & base 2 & 617.06 & 755.86 \\
\hline BA 2 vol (mL) & 19 & 22 & & base 2 vol & 20.5 & 21 \\
\hline BA 3 & 1564.92 & 1760.65 & & base 3 & 765.2 & 662.97 \\
\hline BA 3 vol (mL) & 20 & 19.5 & & base 3 vol & 20 & 21.5 \\
\hline BA 4 & 649 & 765.14 & & base 4 & 342.1 & 389.27 \\
\hline BA 4 vol (mL) & 16 & 15.5 & & base 4 vol & 19.5 & 19 \\
\hline BA 5 & 205.24 & 207.67 & & & & \\
\hline BA 5 vol (mL) & 22 & 19.9 & & & & \\
\hline BA 6 & 151.22 & 162.47 & & & & \\
\hline BA 6 vol (mL) & 23.1 & 22.5 & & & & \\
\hline HA & 2543.7 & 1947.78 & & & & \\
\hline HA vol $(\mathrm{mL})$ & 15 & 15 & & & & \\
\hline $\mathrm{NH}$ & 57.34 & 43.89 & & & & \\
\hline NH vol (mL) & 79 & 88 & & & & \\
\hline FA & 182.75 & 146.13 & & & & \\
\hline FA vol (mL) & 75 & 105 & & & & \\
\hline & & & & & & \\
\hline base trap 1 & 226.58 & 239.1 & & & & \\
\hline base trap 2 & 26.1 & 10.97 & & & & \\
\hline base trap 3 & 5.61 & 3.73 & & & & \\
\hline base trap 4 & 1.7 & 2.27 & & & & \\
\hline solid mass (g) & 8.8577 & 8.4176 & & & & \\
\hline & & & & & & \\
\hline
\end{tabular}




\begin{tabular}{|c|c|c|c|c|c|c|c|}
\hline $\begin{array}{c}\text { Rabbit food } \\
1-d\end{array}$ & & & & & & & \\
\hline Time (hr) & RF 1 & RF 2 & RF 3 & & blank 1 & blank 2 & \\
\hline 0 & 0 & 0 & 0 & & 0 & 0 & \\
\hline 12 & 116765 & 113794 & 116147 & & 129016.7 & 125930.3 & \\
\hline 24 & 114615 & 120268 & 105533.4 & & 50888.6 & 52912.8 & \\
\hline 36 & 38903.1 & 42828.6 & 43220.1 & & 14750.7 & 16424.7 & \\
\hline 48 & 21777.4 & 27961.2 & 28545.6 & & 13445.5 & 12821.5 & \\
\hline 72 & 20677.2 & 15146.9 & 20082.8 & & 7732.63 & 7859.42 & \\
\hline 120 & 13105 & 12178.4 & 15083.03 & & 6661.15 & 7137.62 & \\
\hline 168 & 10075.2 & 10023.9 & 10883.2 & & & & \\
\hline 216 & 8752.31 & 7951.41 & 8972.1 & & & & \\
\hline 264 & 5326.11 & 4948.54 & 5113.43 & & & & \\
\hline after aging & 9542.92 & 9204 & 9231.51 & & 9229.93 & 9215.51 & \\
\hline liquid & 2630.76 & 2751.04 & 2480.15 & & 7965.75 & 8010.78 & \\
\hline after filtration & 715.16 & 954.19 & 736.265 & & & & \\
\hline BA 1 & 1320.23 & 1537.74 & 1598.7 & base 1 & 758.88 & 929.43 & 771.28 \\
\hline BA 1 vol (mL) & 22 & 23 & 23 & base $1 \mathrm{v}$ & 25 & 25 & 25 \\
\hline BA 2 & 993.81 & 1121.41 & 750.38 & base 2 & 1007.31 & 1357.86 & 1360.17 \\
\hline BA 2 vol (mL) & 15 & 15 & 15 & base $2 \mathrm{v}$ & 20 & 20 & 20 \\
\hline BA 3 & 556.16 & 573.09 & 384.72 & base 3 & 617.1 & 867.91 & 551.51 \\
\hline BA 3 vol (mL) & 15 & 15 & 15 & base $3 \mathrm{v}$ & 22 & 20 & 20 \\
\hline BA 4 & 363.03 & 400.1 & 386.96 & base 4 & 981 & 952.8 & 921.09 \\
\hline BA 4 vol (mL) & 15 & 15 & 15 & base $4 \mathrm{v}$ & 22 & 18.5 & 19.5 \\
\hline BA 5 & 237.93 & 249.55 & 247.84 & base 5 & 413.9 & 631.34 & 358.51 \\
\hline BA 5 vol (mL) & 15 & 15 & 15 & base $5 \mathrm{v}$ & 22 & 18.5 & 19.5 \\
\hline $\mathrm{HA}$ & 1668.55 & 1653.975 & 1929.48 & & & & \\
\hline HA vol (mL) & 15 & 15 & 15 & & & & \\
\hline $\mathrm{NH}$ & 222.55 & 210.56 & 213.09 & & & & \\
\hline NH vol (mL) & 153 & 121 & 103 & & & & \\
\hline FA & 158.73 & 111.66 & 123.81 & & & & \\
\hline FA vol (mL) & 158 & 152 & 157 & & & & \\
\hline & & & & & & & \\
\hline & & & & & & & \\
\hline base trap 1 & 532.47 & 532.36 & 614.08 & & & & \\
\hline base trap 2 & 136.03 & 92.31 & 264.67 & & & & \\
\hline base trap 3 & 2.02 & 0.48 & 15.97 & & & & \\
\hline base trap 4 & 1.26 & 0 & 4.78 & & & & \\
\hline & & & & & & & \\
\hline & & & & & & & \\
\hline
\end{tabular}




\begin{tabular}{|c|c|c|c|c|c|c|c|}
\hline \multicolumn{8}{|l|}{$\begin{array}{c}\text { Degraded } \\
\text { Rabbit food } \\
1-d\end{array}$} \\
\hline Time (hr) & DRF 1 & DRF 2 & DRF 3 & & blank 1 & blank 2 & \\
\hline 0 & 0 & 0 & 0 & & 0 & 0 & \\
\hline 12 & 138390 & 131339 & 131298 & & 125099 & 129978 & \\
\hline 24 & 86193.8 & 101180 & 96594.1 & & 56611.6 & 47680.6 & \\
\hline 36 & 57578.6 & 49508.2 & 55040.2 & & 14590.37 & 18224.43 & \\
\hline 48 & 30280.2 & 35905 & 32961.1 & & 13299.35 & 13671.27 & \\
\hline 72 & 22033.4 & 22729.3 & 22957.6 & & 7648.58 & 7773.992 & \\
\hline 120 & 12980.7 & 13121.4 & 13398.7 & & 6588.746 & 7060.037 & \\
\hline 168 & 13585.3 & 12484.6 & 13393.1 & & & & \\
\hline 216 & 10328.6 & 9924.35 & 10439.6 & & & & \\
\hline \multirow[t]{3}{*}{264} & 7896.07 & 8102.86 & 8527.98 & & & & \\
\hline & 5532.17 & 6102.67 & 6023.52 & & & & \\
\hline & 4103.98 & 4987.63 & 5010.75 & & & & \\
\hline after aging & 9132.18 & 9247.82 & 9035.289 & & 9051.99 & 9085.36 & \\
\hline liquid & 3014.42 & 2822.35 & 2918.385 & & 7936.12 & 8041.48 & \\
\hline after filtration & 791.44 & 824.99 & 808.215 & & & & \\
\hline BA 1 & 2066.75 & 2026.91 & 2046.81 & base 1 & 442.18 & 405.41 & 438.29 \\
\hline BA 1 vol (mL) & 15 & 15 & 15 & base $1 \mathrm{v}$ & 20 & 20 & 20 \\
\hline BA 2 & 322.75 & 373.31 & 323.81 & base 2 & 384.94 & 482.14 & 429.37 \\
\hline BA 2 vol (mL) & 20 & 20 & 20 & base $2 \mathrm{v}$ & 20 & 20 & 20 \\
\hline BA 3 & 275.63 & 287.66 & 294.85 & base 3 & 524.55 & 486.63 & 513.35 \\
\hline BA 3 vol (mL) & 20 & 20 & 20 & base $3 \mathrm{v}$ & 20 & 20 & 20 \\
\hline BA 4 & 225.35 & 237 & 241.98 & base 4 & 240.26 & 224.88 & 225.18 \\
\hline BA 4 vol (mL) & 20 & 20 & 20 & base $4 \mathrm{v}$ & 19 & 20 & 19.5 \\
\hline BA 5 & 177.87 & 180.74 & 170.12 & & & & \\
\hline BA 5 vol (mL) & 20 & 20 & 20 & & & & \\
\hline HA & 272.04 & 240.14 & 256.98 & & & & \\
\hline HA vol $(\mathrm{mL})$ & 15 & 15 & 15 & & & & \\
\hline $\mathrm{NH}$ & 117.29 & 142.78 & 113.09 & & & & \\
\hline NH vol (mL) & 104 & 98 & 103 & & & & \\
\hline FA & 76.94 & 79.2 & 76.81 & & & & \\
\hline FA vol (mL) & 158 & 159 & 157 & & & & \\
\hline & & & & & & & \\
\hline base trap 1 & 372.71 & 438.77 & 464.59 & & & & \\
\hline base trap 2 & 38.67 & 112.01 & 121.59 & & & & \\
\hline base trap 3 & 5.13 & 5.2 & 0 & & & & \\
\hline base trap 4 & 1.38 & 1.59 & 0 & & & & \\
\hline & & & & & & & \\
\hline
\end{tabular}




\begin{tabular}{|c|c|c|c|c|c|}
\hline PVC 30-d & & & & & \\
\hline Time (hr) & PVC 1 & PVC 2 & PVC 3 & blank 1 & blank 2 \\
\hline 0 & 0 & 0 & 0 & 0 & 0 \\
\hline 12 & 39459 & 35969.8 & 36671.5 & 24566.3 & 25681.4 \\
\hline 24 & 35457.7 & 34719.6 & 34189.5 & 11012.7 & 11455.7 \\
\hline 36 & 21067.6 & 22207.7 & 22325.9 & 3869.67 & 2861.73 \\
\hline 48 & 18532.6 & 16995.2 & 18182.6 & 1583.37 & 1407.68 \\
\hline 72 & 23540.6 & 26267.8 & 23558.1 & 1507.81 & 1617.05 \\
\hline 96 & 22683.7 & 28315.6 & 22464.8 & & \\
\hline 144 & 32246.3 & 38086.6 & 34237.5 & & \\
\hline 192 & 32647.6 & 32116.3 & 32092.1 & & \\
\hline 240 & 23693.2 & 23828 & 23675 & & \\
\hline 312 & 29440.7 & 30280.6 & 28708 & & \\
\hline 360 & 18594.8 & 16806.5 & 18073.1 & & \\
\hline 408 & 15850.1 & 14703.1 & 15849.2 & & \\
\hline 456 & 13427 & 12574.8 & 12931.9 & & \\
\hline 504 & 8726.9 & 8236.4 & 8833 & & \\
\hline after aging & 1615.94 & 1466.71 & 1603.47 & 1581.42 & 1602.87 \\
\hline liquid & 1358.47 & 1440.48 & 1423.66 & 1418.06 & 1416.21 \\
\hline after filtration & 292.3 & 350.83 & 342.1 & & \\
\hline BA 1 & 11979.52 & 11518 & 12120 & & \\
\hline BA 1vol (mL) & 15 & 15 & 15 & & \\
\hline BA 2 & 11813.4 & 12867.5 & 10697.2 & & \\
\hline BA 2 vol (mL) & 12 & 12 & 12 & & \\
\hline BA 3 & 6136.62 & 5633.25 & 5732.69 & & \\
\hline BA 3 vol (mL) & 12 & 12 & 12 & & \\
\hline BA 4 & 2577.53 & 2150.09 & 2442.11 & & \\
\hline BA 4 vol (mL) & 12 & 12 & 12 & & \\
\hline BA 5 & 1003.59 & 1069.89 & 1158.79 & & \\
\hline BA 5 vol (mL) & 10.5 & 11 & 10.7 & & \\
\hline BA 6 & 120.53 & 113.29 & 111.98 & & \\
\hline BA 6 vol (mL) & 10 & 12.5 & 14 & & \\
\hline & & & & & \\
\hline & & & & & \\
\hline & & & & & \\
\hline & & & & & \\
\hline & & & & & \\
\hline & & & & & \\
\hline & & & & & \\
\hline
\end{tabular}




\begin{tabular}{|c|c|c|c|c|c|}
\hline HDPE 30-d & & & & & \\
\hline Time (hr) & HDPE 1 & HDPE 2 & HDPE 3 & blank 1 & blank 2 \\
\hline 0 & 0 & 0 & 0 & 0 & 0 \\
\hline 12 & 189653 & 155073 & 179172 & 41692.3 & 37892.3 \\
\hline 24 & 135870 & 169331 & 139191 & 18750.3 & 18912.4 \\
\hline 36 & 30682.1 & 27593.5 & 28083.2 & 6123.47 & 6020.5 \\
\hline 48 & 32232.5 & 31427.6 & 32137.5 & 2134.59 & 2437.88 \\
\hline 72 & 23308 & 24420.4 & 23913 & & \\
\hline 96 & 11654 & 12210.2 & 11235.6 & & \\
\hline 144 & 12752.7 & 11610.2 & 10727.6 & & \\
\hline 192 & 6388.41 & 5803.92 & 6060.33 & & \\
\hline 240 & 5329.61 & 5923.11 & 5211.22 & & \\
\hline & & & & & \\
\hline after aging & 3476.11 & 3799.39 & 3665.89 & 3267.91 & 3032.98 \\
\hline liquid & 4655.42 & 3929.8 & 4370.52 & 2748.09 & 2533.76 \\
\hline after filtration & 654.85 & 631.96 & 646.33 & & \\
\hline BA 1 & 2237.71 & 2297.58 & 2247.68 & & \\
\hline BA 1vol (mL) & 13 & 12 & 12.8 & & \\
\hline BA 2 & 447.89 & 497.55 & 501.26 & & \\
\hline BA 2 vol (mL) & 14 & 15 & 16 & & \\
\hline BA 3 & 103.69 & 111.89 & 177.98 & & \\
\hline BA 3 vol (mL) & 14.5 & 15.9 & 15.6 & & \\
\hline & & & & & \\
\hline & & & & & \\
\hline & & & & & \\
\hline & & & & & \\
\hline & & & & & \\
\hline & & & & & \\
\hline & & & & & \\
\hline & & & & & \\
\hline & & & & & \\
\hline & & & & & \\
\hline
\end{tabular}




\begin{tabular}{|c|c|c|c|c|c|c|}
\hline $\begin{array}{c}\text { Office paper } \\
30-\mathrm{d}\end{array}$ & & & & & & \\
\hline Time (hr) & OP 1 & OP 2 & OP 3 & OP 4 & blank 1 & blank 2 \\
\hline 0 & 0 & 0 & 0 & 0 & 0 & 0 \\
\hline 12 & 19961.6 & 19387.1 & 19782.4 & 19299.3 & 21074.9 & 25694.2 \\
\hline 24 & 15676.2 & 16098.2 & 15478 & 14328.7 & 30468 & 32331.4 \\
\hline 36 & 8658.26 & 9145.39 & 9239.87 & 9397.44 & 17709.2 & 18395.7 \\
\hline 48 & 8330.45 & 8664.61 & 12889 & 10237.2 & 9268.25 & 10469.2 \\
\hline 72 & 18936.7 & 12861.6 & 13920.6 & 13889.6 & 7741.97 & 10064.7 \\
\hline 120 & 12118 & 12551.5 & 12228.2 & 12289.7 & 7106.85 & 6467.15 \\
\hline 168 & 18429.8 & 17970.2 & 15416.8 & 16852.9 & 7503.23 & 5465.77 \\
\hline 216 & 10866.7 & 13455 & 13860.4 & 13354.1 & 2490.38 & 2437.65 \\
\hline 264 & 13885 & 12508.8 & 15314.8 & 14523.6 & & \\
\hline & & & & & & \\
\hline after aging & 5976.4 & 5656.75 & 5919.77 & 5743.08 & 5997.06 & 5844.75 \\
\hline liquid & 1428.72 & 1437.27 & & & 4674.35 & 4963.23 \\
\hline after filtration & 517.9 & 522.79 & & & & \\
\hline BA 1 & 364.11 & 379.55 & & base 1 & 523.64 & 506.23 \\
\hline BA 1 vol (mL) & 15 & 14.7 & & base $1 \mathrm{v}$ & 25 & 25.5 \\
\hline BA 2 & 2074.54 & 1994.23 & & base 2 & 358.44 & 323.52 \\
\hline BA 2 vol (mL) & 15.5 & 14.5 & & base $2 \mathrm{v}$ & 25 & 24 \\
\hline BA 3 & 112.46 & 126.57 & & base 3 & 223.87 & 215.89 \\
\hline BA 3 vol (mL) & 25 & 22.5 & & base $3 \mathrm{v}$ & 25 & 25 \\
\hline base trap 1 & 39095 & 40188 & & & & \\
\hline base trap 2 & 42.65 & 32.76 & & & & \\
\hline base trap 3 & 0 & 0 & & & & \\
\hline base trap 4 & 0 & 0 & & & & \\
\hline solid mass $(\mathrm{g})$ & 5.754 & 5.7124 & & & & \\
\hline & & & & & & \\
\hline & & & & & & \\
\hline & & & & & & \\
\hline & & & & & & \\
\hline & & & & & & \\
\hline & & & & & & \\
\hline & & & & & & \\
\hline & & & & & & \\
\hline & & & & & & \\
\hline & & & & & & \\
\hline & & & & & & \\
\hline & & & & & & \\
\hline
\end{tabular}




\begin{tabular}{|c|c|c|c|c|c|c|}
\hline $\begin{array}{c}\text { Degraded } \\
\text { Office paper } \\
30-\mathrm{d}\end{array}$ & & & & & & \\
\hline Time (hr) & DOP 1 & DOP 2 & DOP 3 & DOP 4 & blank 1 & blank 2 \\
\hline 0 & 0 & 0 & 0 & 0 & 0 & 0 \\
\hline 12 & 65091.1 & 60737.4 & 57844.2 & 139357 & 68557.1 & 70399.7 \\
\hline 24 & 52181.3 & 58331.9 & 59390.8 & 77365.5 & 73130.4 & 70724.2 \\
\hline 36 & 29784.8 & 31498.9 & 24941.7 & 42684.8 & 29990.6 & 25525.4 \\
\hline 48 & 25870.3 & 23041.7 & 32428.7 & 27142.8 & 10434.8 & 12096.3 \\
\hline 72 & 29821.6 & 29786.1 & 29999.6 & 29819.8 & 6072.47 & 9460.44 \\
\hline 120 & 24644.8 & 24912.6 & 23782.7 & 20670.7 & 4840.51 & 2716.12 \\
\hline 168 & 33660.9 & 36450.5 & 31988 & 20228.2 & & \\
\hline 216 & 26609.5 & 27254 & 21904.6 & 13663.2 & & \\
\hline 264 & 15635.1 & 13442.2 & 20211.4 & 9089.99 & & \\
\hline after aging & 8959.43 & 8941.2 & 8726.13 & 8875.58 & 8734.01 & 8732.55 \\
\hline liquid & 3055.97 & 2860.1 & & & 7789.25 & 7713.5 \\
\hline after filtration & 1724.94 & 1634.25 & & & & \\
\hline BA 1 & 863.24 & 927.46 & & base 1 & 777.44 & 628.28 \\
\hline BA 1 vol (mL) & 30 & 29 & & base 1 vol & 29 & 31 \\
\hline BA 2 & 5566.24 & 4705.61 & & base 2 & 234.38 & 454.37 \\
\hline BA 2 vol (mL) & 8.5 & 9.5 & & base 2 vol & 29 & 29.5 \\
\hline BA 3 & 460.65 & 342.3 & & base 3 & 221.17 & 187.89 \\
\hline BA 3 vol (mL) & 24 & 24.6 & & base 3 vol & 29 & 29 \\
\hline BA 4 & 279.79 & 223.97 & & base 4 & 157.95 & 144.21 \\
\hline BA 4 vol (mL) & 23 & 20.5 & & base 4 vol & 29 & 30.5 \\
\hline BA 5 & 177.59 & 189.42 & & & & \\
\hline BA 5 vol (mL) & 20.5 & 21.1 & & & & \\
\hline HA & 0 & 0 & & & & \\
\hline HA vol (mL) & 0 & 0 & & & & \\
\hline $\mathrm{NH}$ & 166.81 & 111.38 & & & & \\
\hline NH vol (mL) & 130 & 120 & & & & \\
\hline FA & 228 & 210.71 & & & & \\
\hline FA vol (mL) & 105 & 95 & & & & \\
\hline & & & & & & \\
\hline base trap 1 & 29 & 30.5 & & & & \\
\hline base trap 2 & 532.89 & 548.16 & & & & \\
\hline base trap 3 & 53.31 & 67.21 & & & & \\
\hline base trap 4 & 2.11 & 7.79 & & & & \\
\hline solid mass (g) & 1.54 & 0 & & & & \\
\hline & & & & & & \\
\hline
\end{tabular}




\begin{tabular}{|c|c|c|c|c|c|c|}
\hline $\begin{array}{l}\text { Newsprint 30- } \\
\text { d }\end{array}$ & & & & & & \\
\hline Time (hr) & NP 1 & NP 2 & NP 3 & NP 4 & blank 1 & blank 2 \\
\hline 0 & 0 & 0 & 0 & 0 & 0 & 0 \\
\hline 12 & 127907 & 135533 & 145491 & 137372 & 125099 & 129978 \\
\hline 24 & 63535.3 & 65535.6 & 64545.7 & 58349.1 & 56611.6 & 57680.6 \\
\hline 36 & 29663.9 & 26156.6 & 26389.4 & 27976.7 & 14269.7 & 12823.89 \\
\hline 48 & 22570.8 & 23809.1 & 22608.6 & 20101.1 & 6659.86 & 6853.24 \\
\hline 72 & 29296.8 & 28519.8 & 27895.5 & 27320.1 & 6443.939 & 6904.872 \\
\hline 120 & 18633.6 & 18117 & 17583.4 & 17631.5 & & \\
\hline 168 & 22158.8 & 23011.9 & 23322 & 21950.3 & & \\
\hline 216 & 15568 & 15391.9 & 14506.2 & 14654.8 & & \\
\hline 264 & 6600.63 & 7798.71 & 6704.03 & 8359.83 & & \\
\hline after aging & 8262.13 & 8015.64 & 8090.53 & 8139.91 & 8124.13 & 8208.12 \\
\hline liquid & 1972.12 & 1888.96 & & & 7089.25 & 7013.5 \\
\hline after filtration & 909.96 & 927.47 & & & & \\
\hline BA 1 & 498.7 & 487.95 & & base 1 & 665.22 & 721.97 \\
\hline BA 1 vol (mL) & 15 & 15.5 & & base 1 vol & 23.5 & 21.5 \\
\hline BA 2 & 1742.69 & 2077.85 & & base 2 & 539.21 & 482.85 \\
\hline BA 2 vol (mL) & 17.5 & 16.5 & & base 2 vol & 26.5 & 27.5 \\
\hline BA 3 & 357.38 & 343.78 & & base 3 & 383.64 & 397.61 \\
\hline BA 3 vol (mL) & 25 & 25.5 & & base 3 vol & 22.5 & 24 \\
\hline BA 4 & 296.22 & 287.39 & & base 4 & 237.63 & 241.95 \\
\hline BA 4 vol (mL) & 26 & 25.2 & & base 4 vol & 21 & 24.5 \\
\hline & & & & & & \\
\hline HA & 1687.38 & 2167.01 & & & & \\
\hline HA vol (mL) & 15 & 15 & & & & \\
\hline $\mathrm{NH}$ & 139.44 & 143.21 & & & & \\
\hline NH vol (mL) & 93 & 82 & & & & \\
\hline FA & 208.05 & 237.4 & & & & \\
\hline FA vol (mL) & 105 & 98 & & & & \\
\hline & & & & & & \\
\hline base trap 1 & 180.62 & 226.96 & & & & \\
\hline base trap 2 & 96.26 & 101.54 & & & & \\
\hline base trap 3 & 12.56 & 7.51 & & & & \\
\hline base trap 4 & 1.29 & 1.02 & & & & \\
\hline solid mass $(\mathrm{g})$ & 8.0917 & 8.7153 & & & & \\
\hline & & & & & & \\
\hline
\end{tabular}




\begin{tabular}{|c|c|c|c|c|c|c|}
\hline $\begin{array}{c}\text { Degraded } \\
\text { newsprint 30- } \\
\mathrm{d}\end{array}$ & & & & & & \\
\hline Time (hr) & DNP 1 & DNP 2 & DNP 3 & DNP 4 & blank 1 & blank 2 \\
\hline 0 & 0 & 0 & 0 & 0 & 0 & 0 \\
\hline 12 & 130222 & 132114 & 130189 & 131168 & 132219 & 124985 \\
\hline 24 & 67050.36 & 67146.21 & 46688.11 & 67098.29 & 48578.9 & 43655.1 \\
\hline 36 & 32042.6 & 34882 & 30242.1 & 33462.3 & 13162.7 & 12478.6 \\
\hline 48 & 22984.5 & 22680.3 & 22370 & 22832.4 & 6024.17 & 6942.59 \\
\hline 72 & 25213.4 & 27778.8 & 25553.1 & 26496.1 & 6414.22 & 6488.87 \\
\hline 120 & 20505.8 & 21103.8 & 21507.2 & 20804.8 & 3660.49 & 4238.34 \\
\hline 168 & 24728.7 & 22472.7 & 24507.6 & 23600.7 & & \\
\hline 216 & 13828.5 & 12923.4 & 12819.7 & 13375.8 & & \\
\hline after aging & 7881.49 & 7644.72 & 7974.3 & 7833.53 & 7964.54 & 7804.44 \\
\hline liquid & 2118.46 & 2244.1 & & & 7098.28 & 7090.86 \\
\hline after filtration & 562.32 & 567.38 & & & & \\
\hline BA 1 & 1173.01 & 1285.46 & & base 1 & 608.3 & 763.88 \\
\hline BA 1 vol (mL) & 9 & 10 & & base 1 vol & 18 & 16 \\
\hline BA 2 & 2011.84 & 2244.88 & & base 2 & 641.22 & 705.55 \\
\hline BA 2 vol (mL) & 25 & 25 & & base 2 vol & 18 & 19.5 \\
\hline BA 3 & 1050.44 & 935.45 & & base 3 & 359.55 & 627.29 \\
\hline BA 3 vol $(\mathrm{mL})$ & 26 & 25 & & base 3 vol & 20 & 19.5 \\
\hline BA 4 & 257.09 & 312.92 & & base 4 & 409.23 & 555.32 \\
\hline BA 4 vol (mL) & 19 & 20 & & base 4 vol & 21 & 21.5 \\
\hline BA 5 & 197.83 & 172.09 & & base 5 & 309.21 & 284.13 \\
\hline BA 5 vol (mL) & 21.5 & 22.5 & & base 5 vol & 21 & 21.5 \\
\hline & & & & & & \\
\hline & & & & & & \\
\hline HA & 2289.49 & 2699.41 & & & & \\
\hline HA vol (mL) & 15 & 15 & & & & \\
\hline $\mathrm{NH}$ & 47.76 & 65.09 & & & & \\
\hline NH vol (mL) & 78 & 78 & & & & \\
\hline FA & 142.58 & 343.57 & & & & \\
\hline FA vol (mL) & 105 & 92 & & & & \\
\hline & & & & & & \\
\hline base trap 1 & 199.61 & 216.55 & & & & \\
\hline base trap 2 & 101 & 56.69 & & & & \\
\hline base trap 3 & 2.83 & 0.83 & & & & \\
\hline base trap 4 & 0 & 0 & & & & \\
\hline solid mass (g) & 8.8001 & 8.9595 & & & & \\
\hline & & & & & & \\
\hline
\end{tabular}




\begin{tabular}{|c|c|c|c|c|c|c|}
\hline $\begin{array}{c}\text { Degraded } \\
\text { Rabbit food } \\
30-\mathrm{d}\end{array}$ & & & & & & \\
\hline Time (hr) & DRF 1 & DRF 2 & & blank 1 & blank 2 & \\
\hline 0 & 0 & 0 & & 0 & 0 & \\
\hline 12 & 62678.5 & 72528.2 & & 129016.7 & 115930.3 & \\
\hline 24 & 118121 & 124427 & & 50888.6 & 57912.8 & \\
\hline 36 & 74303.5 & 57947.9 & & 27230.7 & 23044.8 & \\
\hline 48 & 44362.7 & 33915.1 & & 17452.9 & 16300.4 & \\
\hline 72 & 23340.1 & 15401.6 & & 6549.6 & 6828.04 & \\
\hline 96 & 8504.11 & 11653.1 & & & & \\
\hline 144 & 7997.95 & 10992.7 & & & & \\
\hline 192 & 15235.2 & 14985.4 & & & & \\
\hline 240 & 7079.64 & 7689.41 & & & & \\
\hline 288 & 5252.69 & 5862.14 & & & & \\
\hline 336 & 4013.25 & 3994.12 & & & & \\
\hline after aging & 9173.97 & 9104.3 & & 9051.99 & 9085.36 & \\
\hline liquid & 2807.73 & 2822.35 & & 8076.12 & 7941.48 & \\
\hline after filtration & 877.42 & 873.75 & & & & \\
\hline & & & & & & \\
\hline BA 1 & 1451.67 & 1211.45 & base 1 & 617.3 & 610.14 & \\
\hline BA 1 vol (mL) & 22 & 23 & base $1 \mathrm{v}$ & 28 & 29.5 & \\
\hline BA 2 & 689.21 & 644.28 & base 2 & 617.3 & 610.14 & \\
\hline BA 2 vol (mL) & 20 & 20.5 & base $2 \mathrm{v}$ & 28 & 29.5 & \\
\hline BA 3 & 448.52 & 465.21 & base 3 & 215.94 & 225.18 & \\
\hline BA 3 vol (mL) & 20 & 20.5 & base $3 \mathrm{v}$ & 30 & 30 & \\
\hline BA 4 & 240.89 & 177.73 & & & & \\
\hline BA 4 vol (mL) & 17 & 18 & & & & \\
\hline & & & & & & \\
\hline & & & & & & \\
\hline & & & & & & \\
\hline $\mathrm{HA}$ & 1803.3 & 1898.55 & & & & \\
\hline HA vol (mL) & 15 & 15 & & & & \\
\hline $\mathrm{NH}$ & 113.63 & 141.09 & & & & \\
\hline NH vol (mL) & 98 & 78 & & & & \\
\hline FA & 103.26 & 99.2 & & & & \\
\hline FA vol (mL) & 135 & 113 & & & & \\
\hline & & & & & & \\
\hline & & & & & & \\
\hline base trap 1 & 303.57 & 397.51 & & & & \\
\hline base trap 2 & 246.03 & 255.92 & & & & \\
\hline base trap 3 & 108.53 & 14.03 & & & & \\
\hline base trap 4 & 0 & 1.03 & & & & \\
\hline & & & & & & \\
\hline
\end{tabular}




\begin{tabular}{|c|c|c|c|c|c|}
\hline PVC 180-d & & & & & \\
\hline Time (hr) & PVC 1 & PVC 2 & PVC 3 & blank 1 & blank 2 \\
\hline 0 & 0 & 0 & 0 & 0 & 0 \\
\hline 12 & 36531 & 32166 & 33546 & 24566.3 & 25681.4 \\
\hline 24 & 22254.1 & 22820.5 & 22013.6 & 11012.7 & 11455.7 \\
\hline 36 & 31379.4 & 26098 & 27099 & 3869.67 & 2861.73 \\
\hline 48 & 14058.9 & 14797.7 & 14009.6 & 1583.37 & 1407.68 \\
\hline 72 & 25007.3 & 26680.4 & 26030.5 & 1507.81 & 1617.05 \\
\hline 96 & 19752.2 & 22897.5 & 21947.1 & & \\
\hline 144 & 32472.5 & 33137.9 & 32865.9 & & \\
\hline 192 & 32277.1 & 35029.3 & 32426.5 & & \\
\hline 240 & 23471.1 & 23493.9 & 23526.9 & & \\
\hline 312 & 20259 & 21720.6 & 20856.3 & & \\
\hline 360 & 15213.6 & 16152.3 & 14589.9 & & \\
\hline 408 & 12964.1 & 14466 & 14731.4 & & \\
\hline 456 & 14479.2 & 15663.2 & 15201.3 & & \\
\hline 504 & 10640.1 & 11530.1 & 11125.6 & & \\
\hline after aging & 1278.05 & 1221.62 & 1233.47 & 1581.42 & 1602.87 \\
\hline liquid & 1528.59 & 1575.8 & 1423.66 & 1418.06 & 1416.21 \\
\hline after filtration & 456.18 & 514.18 & 342.1 & & \\
\hline BA 1 & 17097.7 & 16649.2 & 17293.1 & & \\
\hline BA 1vol (mL) & 10.5 & 10 & 10 & & \\
\hline BA 2 & 10037.08 & 12699.03 & 11124.69 & & \\
\hline BA 2 vol (mL) & 10 & 10 & 11 & & \\
\hline BA 3 & 6264.9 & 6875.23 & 6438.29 & & \\
\hline BA 3 vol (mL) & 12 & 12 & 12 & & \\
\hline BA 4 & 3131.98 & 3435.84 & 3498.45 & & \\
\hline BA 4 vol (mL) & 12 & 12 & 12 & & \\
\hline BA 5 & 3759.43 & 3658.46 & 3515.33 & & \\
\hline BA 5 vol (mL) & 10.5 & 11 & 10.7 & & \\
\hline BA 6 & 1254.33 & 1564.32 & 1137.29 & & \\
\hline BA 6 vol $(\mathrm{mL})$ & 10 & 11 & 10.5 & & \\
\hline BA 7 & 969.43 & 875.24 & 961.28 & & \\
\hline BA 7 vol (mL) & 10 & 10 & 10 & & \\
\hline BA 8 & 223.98 & 214.89 & 311.66 & & \\
\hline BA 8 vol (mL) & 10.5 & 11 & 10.5 & & \\
\hline & & & & & \\
\hline & & & & & \\
\hline & & & & & \\
\hline & & & & & \\
\hline
\end{tabular}




\begin{tabular}{|c|c|c|c|c|c|}
\hline HDPE 180-d & & & & & \\
\hline Time (hr) & HDPE 1 & HDPE 2 & HDPE 3 & blank 1 & blank 2 \\
\hline 0 & 0 & 0 & 0 & 0 & 0 \\
\hline 12 & 199995 & 194534 & 196021 & 40850.3 & 36652 \\
\hline 24 & 130438 & 121577 & 123434 & 18774.3 & 18562.4 \\
\hline 36 & 29753.9 & 31182.1 & 30837.9 & 6194.89 & 6108.96 \\
\hline 48 & 12892.2 & 12510.8 & 13003.5 & 3424.98 & 3125.54 \\
\hline 72 & 22550.8 & 23374.6 & 23835.5 & & \\
\hline 96 & 10265.93 & 11517.28 & 11965.41 & & \\
\hline 144 & 10667.2 & 11031.41 & 11327.9 & & \\
\hline 192 & 7952.31 & 7741.21 & 7512.22 & & \\
\hline 240 & 5386.52 & 5412.23 & 5874.98 & & \\
\hline & & & & & \\
\hline after aging & 3558.42 & 3749.92 & 3639.219 & 3365.66 & 3223.76 \\
\hline liquid & 4204.6 & 5421.23 & 4651.29 & 2746.34 & 2864.99 \\
\hline after filtration & 829.51 & 801.3 & 858.93 & & \\
\hline BA 1 & 1081.96 & 1210.95 & 1217.24 & & \\
\hline BA 1vol (mL) & 13 & 12 & 12.8 & & \\
\hline BA 2 & 245.5 & 235.89 & 275.98 & & \\
\hline BA 2 vol (mL) & 14 & 15 & 16 & & \\
\hline BA 3 & 103.69 & 111.89 & 177.98 & & \\
\hline BA 3 vol (mL) & 14.5 & 15.9 & 15.6 & & \\
\hline & & & & & \\
\hline & & & & & \\
\hline & & & & & \\
\hline & & & & & \\
\hline & & & & & \\
\hline & & & & & \\
\hline & & & & & \\
\hline & & & & & \\
\hline & & & & & \\
\hline & & & & & \\
\hline
\end{tabular}




\begin{tabular}{|c|c|c|c|c|c|c|}
\hline $\begin{array}{c}\text { Office paper } \\
180-d\end{array}$ & & & & & & \\
\hline Time (hr) & OP 1 & OP 2 & OP 3 & OP 4 & blank 1 & blank 2 \\
\hline 0 & 0 & 0 & 0 & 0 & & \\
\hline 12 & 19046.3 & 17344 & 19202.7 & 19870.3 & & \\
\hline 24 & 16858.3 & 12802.6 & 15403.7 & 13419.8 & & \\
\hline 36 & 11890.3 & 9698.42 & 9868.95 & 9874.91 & & \\
\hline 48 & 7846.41 & 7446.3 & 8131.03 & 7428.51 & & \\
\hline 72 & 11846.8 & 12378.7 & 9816.06 & 10672.9 & & \\
\hline 120 & 8480.82 & 9118.61 & 9073.04 & 8191.54 & & \\
\hline 168 & 10376 & 12490.7 & 10243.8 & 10205.9 & & \\
\hline 216 & 7596.32 & 9004.12 & 7512.12 & 7516.8 & & \\
\hline 264 & 7424.09 & 8504.96 & 7842.96 & 7007.46 & & \\
\hline & & & & & & \\
\hline after aging & 5410.94 & 5548.13 & 5673.04 & 5467.45 & 5416.18 & 5552.17 \\
\hline liquid & 2375.08 & 2452.98 & & & 4398.07 & 4486.65 \\
\hline after filtration & 1625.67 & 1218.43 & & & & \\
\hline BA 1 & 2370.98 & 2456.17 & & base 1 & 540.03 & 464.89 \\
\hline BA 1 vol (mL) & 7 & 7 & & base $1 \mathrm{v}$ & 22 & 23 \\
\hline BA 2 & 281.63 & 378.56 & & base 2 & 199.17 & 284.2 \\
\hline BA 2 vol (mL) & 12 & 13 & & base $2 \mathrm{v}$ & 20 & 20 \\
\hline BA 3 & 447.89 & 497.55 & & base 3 & 265.98 & 210.62 \\
\hline BA 3 vol (mL) & 14 & 15 & & base $3 \mathrm{v}$ & 20 & 20 \\
\hline BA 4 & 103.69 & 111.89 & & base 4 & 227.51 & 176.57 \\
\hline BA 4 vol (mL) & 14.5 & 15.9 & & base $4 \mathrm{v}$ & 19 & 20 \\
\hline BA 5 & 218.97 & 195.12 & & & & \\
\hline BA 5 vol (mL) & 25 & 23 & & & & \\
\hline BA 6 & 154.23 & 172.12 & & & & \\
\hline BA 6 vol (mL) & 22 & 19 & & & & \\
\hline & & & & & & \\
\hline HA & 0 & 0 & & & & \\
\hline HA vol (mL) & 0 & 0 & & & & \\
\hline $\mathrm{NH}$ & 116.66 & 104.21 & & & & \\
\hline NH vol (mL) & 93 & 97 & & & & \\
\hline FA & 178.51 & 197.41 & & & & \\
\hline FA vol (mL) & 75 & 80 & & & & \\
\hline base trap 1 & 418.18 & 356.22 & & & & \\
\hline base trap 2 & 117.78 & 138.98 & & & & \\
\hline base trap 3 & 13.33 & 10.33 & & & & \\
\hline base trap 4 & 3.97 & 0 & & & & \\
\hline solid mass (g) & 5.1039 & 4.9842 & & & & \\
\hline
\end{tabular}




\begin{tabular}{|c|c|c|c|c|c|c|}
\hline $\begin{array}{c}\text { Degraded } \\
\text { Office paper } \\
180-\mathrm{d} \\
\end{array}$ & & & & & & \\
\hline Time (hr) & DOP 1 & DOP 2 & DOP 3 & DOP 4 & blank 1 & blank 2 \\
\hline 0 & 0 & 0 & 0 & 0 & & \\
\hline 12 & 43762.3 & 45936.6 & 47595.7 & 50736.6 & & \\
\hline 24 & 38435.9 & 47418.1 & 49149.5 & 45285.9 & & \\
\hline 36 & 24317.6 & 28145.4 & 27064.6 & 22571 & & \\
\hline 48 & 23929 & 25549.5 & 23549.5 & 29836.2 & & \\
\hline 72 & 35001.8 & 37892.4 & 34628.6 & 31761.3 & & \\
\hline 120 & 20327.4 & 22405.9 & 19017.9 & 23476.1 & & \\
\hline 168 & 39909.6 & 29901.9 & 38237.2 & 27560.2 & & \\
\hline 216 & 22003.2 & 22881.3 & 19501.8 & 26067.6 & & \\
\hline 264 & 13565.4 & 13271.3 & 12058 & 11770.1 & & \\
\hline after aging & 8784.82 & 8822.13 & 8697.89 & 8768.28 & 8828.41 & 8776.34 \\
\hline liquid & 3870.08 & 3820.17 & & & 7764.37 & 7859.33 \\
\hline after filtration & 2988.74 & 3000.47 & & & & \\
\hline & & & & & & \\
\hline BA 1 & 4149.29 & 4137.34 & & base 1 & 630.43 & 648.65 \\
\hline BA 1 vol (mL) & 15 & 16.5 & & base 1 vol & 22 & 23 \\
\hline BA 2 & 746.2 & 752.44 & & base 2 & 310.83 & 176.68 \\
\hline BA 2 vol (mL) & 9.5 & 10.5 & & base 2 vol & 21 & 20 \\
\hline BA 3 & 538.28 & 468.93 & & base 3 & 139.11 & 196.67 \\
\hline BA 3 vol (mL) & 20 & 20 & & base 3 vol & 20 & 20 \\
\hline BA 4 & 300.4 & 281.07 & & base 4 & 98.75 & 88.24 \\
\hline BA 4 vol (mL) & 21 & 22 & & base 4 vol & 19 & 20 \\
\hline BA 5 & 245.55 & 243.56 & & & & \\
\hline BA 5 vol (mL) & 23 & 24.5 & & & & \\
\hline BA 6 & 197.53 & 184.12 & & & & \\
\hline BA 6 vol (mL) & 25 & 23 & & & & \\
\hline HA & 0 & 0 & & & & \\
\hline HA vol $(\mathrm{mL})$ & 0 & 0 & & & & \\
\hline $\mathrm{NH}$ & 116.66 & 104.21 & & & & \\
\hline NH vol (mL) & 93 & 97 & & & & \\
\hline FA & 178.51 & 197.41 & & & & \\
\hline FA vol (mL) & 75 & 80 & & & & \\
\hline hase tran 1 & 60138 & 5973 & & & & \\
\hline base trap 1 & $\begin{array}{c}001.58 \\
66.1\end{array}$ & $\frac{591.3}{57.41}$ & & & & \\
\hline base trap 3 & 8.57 & 17.27 & & & & \\
\hline base trap 4 & 0.68 & 0 & & & & \\
\hline solid mass (g) & 5.5637 & 5.8742 & & & & \\
\hline & & & & & & \\
\hline
\end{tabular}




\begin{tabular}{|c|c|c|c|c|c|c|}
\hline $\begin{array}{c}\text { Newsprint } \\
180-d\end{array}$ & & & & & & \\
\hline Time (hr) & NP 1 & NP 2 & NP 3 & NP 4 & blank 1 & blank 2 \\
\hline 0 & 0 & 0 & 0 & 0 & 0 & 0 \\
\hline 12 & 130232 & 120095 & 116616 & 111668 & 123934 & 124125 \\
\hline 24 & 73736.2 & 68028.6 & 80480.2 & 69841.2 & 51362.6 & 52358.7 \\
\hline 36 & 29177.8 & 31001.2 & 34224.7 & 35308.9 & 23137.9 & 18150.9 \\
\hline 48 & 16744.8 & 23848.8 & 23564.2 & 23533.9 & 6515.95 & 5430.58 \\
\hline 72 & 26663.2 & 36742.2 & 35941.7 & 33604.2 & 4047.64 & 4075.23 \\
\hline 120 & 16686.1 & 14185.9 & 20757.8 & 18306.6 & & \\
\hline 168 & 20059.9 & 15979.8 & 21956.1 & 20368.3 & & \\
\hline 216 & 10684.5 & 9051.92 & 11444.6 & 14733.6 & & \\
\hline 264 & 4562.46 & 4301.65 & 7728.76 & 8744.51 & & \\
\hline after aging & 8246.4 & 7978.15 & 8030.1 & 8084.88 & 8006.29 & 7087.65 \\
\hline liquid & 2534.69 & 2527.46 & & & 8116.35 & 6998.65 \\
\hline after filtration & 1457.85 & 1466.69 & & & & \\
\hline BA 1 & 1197.5 & 1199.24 & & base 1 & 715.37 & 655.62 \\
\hline BA 1 vol (mL) & 17 & 19 & & base $1 \mathrm{vol}$ & 20 & 21 \\
\hline BA 2 & 496.46 & 512.18 & & base 2 & 447.86 & 421.41 \\
\hline BA 2 vol (mL) & 14 & 15 & & base 2 vol & 22 & 20.5 \\
\hline BA 3 & 469.13 & 504.21 & & base 3 & 614.11 & 636.14 \\
\hline BA 3 vol (mL) & 18 & 18 & & base 3 vol & 20 & 20 \\
\hline BA 4 & 264.55 & 262.83 & & base 4 & 494.15 & 468.26 \\
\hline BA 4 vol (mL) & 20 & 21 & & base 4vol & 19 & 22 \\
\hline BA 5 & 204.87 & 199.75 & & base 5 & 332.15 & 351.29 \\
\hline BA 5 vol (mL) & 22 & 21 & & base 5 vol & 21 & 20 \\
\hline BA 6 & 124.85 & 137.96 & & base 6 & 197.26 & 156.42 \\
\hline BA 6 vol (mL) & 19.5 & 22 & & base 6 vol & 21 & 20 \\
\hline HA & 1588.41 & 1637.86 & & & & \\
\hline HA vol (mL) & 15 & 15 & & & & \\
\hline NH & 103.76 & 129.7 & & & & \\
\hline $\mathrm{NH}$ vol (mL) & 138 & 142 & & & & \\
\hline FA & 141.16 & 139.92 & & & & \\
\hline FA vol (mL) & 202 & 197 & & & & \\
\hline & & & & & & \\
\hline base trap 1 & 329.84 & 316.33 & & & & \\
\hline base trap 2 & 107.98 & 229.28 & & & & \\
\hline base trap 3 & 6.44 & 15.87 & & & & \\
\hline base trap 4 & 0.12 & 0 & & & & \\
\hline solid mass (g) & 6.512 & 6.2932 & & & & \\
\hline & & & & & & \\
\hline
\end{tabular}




\begin{tabular}{|c|c|c|c|c|c|c|}
\hline $\begin{array}{c}\text { Degraded } \\
\text { newsprint } \\
180-\mathrm{d} \\
\end{array}$ & & & & & & \\
\hline Time (hr) & DNP 1 & DNP 2 & DNP 3 & DNP 4 & blank 1 & blank 2 \\
\hline 0 & 0 & 0 & 0 & 0 & 0 & 0 \\
\hline 12 & 118885 & 116990 & 125639 & 113978 & 115397 & 120360 \\
\hline 24 & 73138 & 75612 & 76617 & 77846 & 37829.3 & 42658.4 \\
\hline 36 & 34754.2 & 34794.2 & 37413.1 & 36571.2 & 12384.9 & 16587.2 \\
\hline 48 & 23226.4 & 25979.8 & 24306.8 & 28936.2 & 6489.62 & 5215.41 \\
\hline 72 & 26527.4 & 26888.7 & 24353.4 & 25103.2 & 4029.12 & 4983.41 \\
\hline 120 & 26887.5 & 30990 & 26637.3 & 26784.2 & 3716.52 & 2488.79 \\
\hline 168 & 18373.4 & 20052.5 & 16939.7 & 15423.6 & & \\
\hline 216 & 14858.3 & 16315.2 & 10932 & 11203.2 & & \\
\hline after aging & 7738.9 & 7350 & 7857.95 & 7797.6 & 7630.22 & 7845.66 \\
\hline liquid & 1569.4 & 1717.35 & & & 6845.21 & 6968.45 \\
\hline after filtration & 512.81 & 475.99 & & & & \\
\hline BA 1 & 2117.66 & 2004.03 & & base 1 & 453.44 & 388.97 \\
\hline BA 1 vol (mL) & 15 & 15 & & base 1 vol & 19 & 22 \\
\hline BA 2 & 2796.29 & 2326.58 & & base 2 & 637.24 & 598.46 \\
\hline BA 2 vol (mL) & 10 & 10 & & base 2 vol & 19 & 20 \\
\hline BA 3 & 1470.66 & 1276.74 & & base 3 & 359.69 & 401.2 \\
\hline BA 3 vol (mL) & 15 & 16 & & base 3 vol & 20 & 21 \\
\hline BA 4 & 731.66 & 612.21 & & base 4 & 227.89 & 201.33 \\
\hline BA 4 vol (mL) & 20 & 20 & & base 4 vol & 21 & 20.5 \\
\hline BA 5 & 372.56 & 447.16 & & base 5 & 129.88 & 103.56 \\
\hline BA 5 vol (mL) & 20 & 20 & & base 5 vol & 20 & 21 \\
\hline BA 6 & 237.97 & 289.21 & & & & \\
\hline BA 6 vol (mL) & 20 & 20 & & & & \\
\hline BA 7 & 157.98 & 189.54 & & & & \\
\hline BA 7 vol (mL) & 20 & 19 & & & & \\
\hline HA & 1567.41 & 1632.11 & & & & \\
\hline HA vol (mL) & 15 & 15 & & & & \\
\hline $\mathrm{NH}$ & 106.23 & 114.66 & & & & \\
\hline NH vol (mL) & 128 & 130 & & & & \\
\hline FA & 194.42 & 201.33 & & & & \\
\hline FA vol (mL) & 152 & 154 & & & & \\
\hline & & 2307 & & & & \\
\hline $\begin{array}{l}\text { base trap } 1 \\
\text { base trap } 2\end{array}$ & $\frac{231}{149.2}$ & $\frac{230.1}{110}$ & & & & \\
\hline base trap 3 & 39.7 & 9.87 & & & & \\
\hline base trap 4 & 25.1 & 1.51 & & & & \\
\hline solid mass (g) & 8.704 & 10.2388 & & & & \\
\hline & & & & & & \\
\hline
\end{tabular}




\begin{tabular}{|c|c|c|c|c|c|c|c|}
\hline \multicolumn{8}{|l|}{$\begin{array}{c}\text { Degraded } \\
\text { Rabbit food } \\
180-d\end{array}$} \\
\hline Time (hr) & DRF 1 & DRF 2 & DRF 3 & & blank 1 & blank 2 & \\
\hline 0 & 0 & 0 & 0 & & 0 & 0 & \\
\hline 12 & 40972.4 & 43261.8 & 40426.8 & & 129016.7 & 115930.3 & \\
\hline 24 & 64934.1 & 65776.7 & 69457.2 & & 50888.6 & 57912.8 & \\
\hline 36 & 69641.7 & 62942.7 & 65471.7 & & 27230.7 & 23044.8 & \\
\hline 48 & 48094.3 & 49935 & 47866.7 & & 17452.9 & 16300.4 & \\
\hline 72 & 38896.5 & 38672.9 & 41974 & & 6549.6 & 6828.04 & \\
\hline 96 & 22557.2 & 27105.4 & 23608.4 & & & & \\
\hline 144 & 16676.7 & 17956.18 & 19723.9 & & & & \\
\hline 192 & 20679.7 & 17741.2 & 19622.8 & & & & \\
\hline 240 & 13840.1 & 13087.1 & 12500.2 & & & & \\
\hline 288 & 8138.78 & 8328.73 & 8338.49 & & & & \\
\hline 336 & 6329.41 & 6221.43 & 6425.89 & & & & \\
\hline after aging & 8866.02 & 9204.12 & 9282.65 & & 9034.19 & 9124.57 & \\
\hline liquid & 3625.59 & 3766.22 & 3633.98 & & 7928.07 & 8186.65 & \\
\hline after filtration & 1098.5 & 1110.22 & 858.93 & & & & \\
\hline BA 1 & 1031.36 & 993.42 & 1265.22 & base 1 & 636.11 & 720.03 & 719.23 \\
\hline BA $1 \mathrm{vol}(\mathrm{mL})$ & 18.5 & 20.5 & 19 & base $1 \mathrm{v}$ & 25 & 25 & 25 \\
\hline BA 2 & 344.79 & 359.36 & 341.28 & base 2 & 368.97 & 491.1 & 445.89 \\
\hline BA $2 \mathrm{vol}(\mathrm{mL})$ & 16 & 15 & 16 & base $2 \mathrm{v}$ & 25 & 25 & 25 \\
\hline BA 3 & 181.14 & 187.01 & 197.41 & base 3 & 263.13 & 230.08 & 252.79 \\
\hline BA $3 \mathrm{vol}(\mathrm{mL})$ & 25 & 25 & 25 & base $3 \mathrm{v}$ & 25 & 24.5 & 23.5 \\
\hline BA 4 & 121.89 & 148.87 & 175.49 & base 4 & 179.83 & 108.85 & 152.13 \\
\hline BA 4 vol (mL) & 22 & 23 & 24 & base $4 \mathrm{v}$ & 25 & 25 & 25 \\
\hline & & & & & & & \\
\hline & & & & & & & \\
\hline $\mathrm{HA}$ & 510.22 & 482.13 & & & & & \\
\hline HA vol $(\mathrm{mL})$ & 15 & 15 & & & & & \\
\hline $\mathrm{NH}$ & 176.57 & 242.82 & & & & & \\
\hline NH vol (mL) & 118 & 109 & & & & & \\
\hline FA & 285.79 & 191.87 & & & & & \\
\hline FA vol (mL) & 110 & 98 & & & & & \\
\hline & & & & & & & \\
\hline & & base vol & & base vol & & & \\
\hline base trap 1 & 550.3 & 23 & 722.69 & 15 & & & \\
\hline base trap 2 & 95.96 & 16 & 146.07 & 15 & & & \\
\hline base trap 3 & 22.26 & 16 & 13.39 & 15 & & & \\
\hline base trap 4 & 30.11 & 12 & 0 & 15 & & & \\
\hline & & & & & & & \\
\hline & & & & & & & \\
\hline
\end{tabular}




\section{Appendix B Data of manuscript 2}

TABLE B.1 Enzymatic Hydrolysis Data (dpm)

\begin{tabular}{|c|c|c|c|c|}
\hline office paper 1-d & & & & \\
\hline Time (hr) & w/enzyme 1 & w/enzyme 2 & w/o enzyme 1 & w/o enzyme 2 \\
\hline 336 & 1922.13 & 1968.53 & 820.88 & 1752.44 \\
\hline 360 & 1305.77 & 1214.83 & 1069.44 & 1268.99 \\
\hline 408 & 1159.57 & 1094.91 & 1117.81 & 1532.11 \\
\hline 456 & 1086.9 & 1686.79 & 2332.83 & 1508.87 \\
\hline \multicolumn{5}{|l|}{ office paper $30-\mathrm{d}$} \\
\hline Time $(\mathrm{hr})$ & w/enzyme 1 & w/enzyme 2 & w/o enzyme 1 & w/o enzyme 2 \\
\hline 336 & 2338.9 & 2798.86 & 3173.25 & 3021.56 \\
\hline 360 & 1507.21 & 1439.21 & 1128.3 & 1143.56 \\
\hline 408 & 2025.66 & 2187.21 & 2152.36 & 2310.33 \\
\hline 456 & 1969.33 & 2354.2 & 2509.88 & 2140.11 \\
\hline \multicolumn{5}{|l|}{ office paper 180 -d } \\
\hline Time $(\mathrm{hr})$ & w/enzyme 1 & w/enzyme 2 & w/o enzyme 1 & w/o enzyme 2 \\
\hline 336 & 4648.21 & 4023.1 & 5126.84 & 4986.52 \\
\hline 360 & 3974.89 & 4016.32 & 3395.69 & 3400.18 \\
\hline 408 & 2844.65 & 2856.21 & 1875.56 & 1572.41 \\
\hline 456 & 2013.56 & 2451.88 & 1486.75 & 1754.23 \\
\hline $\begin{array}{c}\text { Degraded office paper } \\
1-d\end{array}$ & w/enzyme 1 & w/enzyme 2 & w/o enzyme 1 & w/o enzyme 2 \\
\hline 288 & 6111.99 & 5424.99 & 3710.93 & 3917.72 \\
\hline 336 & 3319.2 & 3564.98 & 4928.37 & 4410.39 \\
\hline 384 & 2128.84 & 3324.68 & 4136.53 & 3916.2 \\
\hline 432 & 2037.21 & 1998.06 & 2839.64 & 2976.55 \\
\hline $\begin{array}{c}\text { Degraded office paper } \\
30-\mathrm{d}\end{array}$ & w/enzyme 1 & w/enzyme 2 & w/o enzyme 1 & w/o enzyme 2 \\
\hline 288 & 13213.2 & 11284.2 & 15324.1 & 12235.7 \\
\hline 336 & 10332.5 & 10652.6 & 11584.5 & 10238.8 \\
\hline 384 & 7449.38 & 8383.99 & 7560.11 & 8673.29 \\
\hline 432 & 5229.45 & 4309.67 & 4490.15 & 5239.57 \\
\hline $\begin{array}{l}\text { Degraded office paper } \\
30-\mathrm{d}\end{array}$ & w/enzyme 1 & w/enzyme 2 & w/o enzyme 1 & w/o enzyme 2 \\
\hline 288 & 13829.9 & 14079.2 & 14322.1 & 17165 \\
\hline 336 & 9063.23 & 10090.2 & 8821.6 & 4792.11 \\
\hline 384 & 7793.5 & 9265.88 & 7188.37 & 3546.43 \\
\hline 432 & 2591.68 & 4294.73 & 3466.19 & 1437.17 \\
\hline
\end{tabular}




\begin{tabular}{|c|c|c|c|c|}
\hline newsprint 1-d & & & & \\
\hline Time (hr) & w/enzyme 1 & w/enzyme 2 & w/o enzyme 1 & w/o enzyme 2 \\
\hline 288 & 2562.45 & 2577.61 & 7496.16 & 7045.65 \\
\hline 336 & 4889.71 & 4802.48 & 5231.83 & 5528.65 \\
\hline 384 & 4547.2 & 4194.82 & 3856.23 & 3815.66 \\
\hline 432 & 2348.37 & 2633.63 & 2632 & 1765.66 \\
\hline \multicolumn{5}{|l|}{ newsprint 30-d } \\
\hline Time (hr) & w/enzyme 1 & w/enzyme 2 & w/o enzyme 1 & w/o enzyme 2 \\
\hline 288 & 6488.91 & 6477.71 & 3697.3 & 2564.1 \\
\hline 336 & 2541.483 & 2452.48 & 3363.97 & 2799.39 \\
\hline 384 & 1971.48 & 2295.38 & 3044.01 & 2190.97 \\
\hline 432 & 1936.04 & 2162.47 & 1853.38 & 1764.54 \\
\hline \multicolumn{5}{|l|}{ newsprint $180-\mathrm{d}$} \\
\hline Time (hr) & w/enzyme 1 & w/enzyme 2 & w/o enzyme 1 & w/o enzyme 2 \\
\hline 288 & 3518.55 & 2829.28 & 4896.98 & 2101.62 \\
\hline 336 & 2108.34 & 1556.79 & 3823.35 & 3994.32 \\
\hline 384 & 1506.13 & 1117.11 & 1155.3 & 1375.2 \\
\hline 432 & 701.19 & 465.96 & 431.55 & 471.33 \\
\hline $\begin{array}{l}\text { Degraded newsprint 1- } \\
\mathrm{d}\end{array}$ & w/enzyme 1 & w/enzyme 2 & w/o enzyme 1 & w/o enzyme 2 \\
\hline 240 & 4125.84 & 5819.98 & 4956.9 & 5328.79 \\
\hline 288 & 3044.01 & 4456.27 & 2383.07 & 3378.09 \\
\hline 336 & 2342.16 & 2765.18 & 2028.31 & 2139.04 \\
\hline 384 & 2119.58 & 2140.39 & 2208.18 & 2020.71 \\
\hline $\begin{array}{l}\text { Degraded newsprint } \\
30-\mathrm{d}\end{array}$ & w/enzyme 1 & w/enzyme 2 & w/o enzyme 1 & w/o enzyme 2 \\
\hline 240 & 6471.45 & 6636.87 & 6904.56 & 6554.16 \\
\hline 288 & 3424.71 & 3023.55 & 3369.87 & 3224.13 \\
\hline 336 & 2433.67 & 2874.3 & 2566.34 & 2532.09 \\
\hline 384 & 2009.21 & 1919.34 & 1876.39 & 1965.43 \\
\hline $\begin{array}{l}\text { Degraded newsprint } \\
30-\mathrm{d}\end{array}$ & w/enzyme 1 & w/enzyme 2 & w/o enzyme 1 & w/o enzyme 2 \\
\hline 240 & 6231.3 & 6345.3 & 9329.22 & 6563.4 \\
\hline 288 & 3129 & 2939.87 & 3256.86 & 3108.577 \\
\hline 336 & 3129.45 & 2847.65 & 2712.32 & 2626.13 \\
\hline 384 & 2110.35 & 1985.63 & 1954.21 & 1974.12 \\
\hline
\end{tabular}


TABLE B.2 Bioavailability of Toluene Sorbed to Sorbent Composite and Isolated Lignin (dpm)

\begin{tabular}{|c|c|c|c|c|c|c|c|}
\hline $\begin{array}{c}\text { Newsprint } \\
1-\mathrm{d}\end{array}$ & & & & & & & \\
\hline Time $(\mathrm{hr})$ & NP 1 & NP 2 & NP 3 & NP 4 & $\begin{array}{c}\text { NP } \\
\text { lignin 1 }\end{array}$ & $\begin{array}{c}\mathrm{NP} \\
\text { lignin } 2\end{array}$ & $\begin{array}{c}\mathrm{NP} \\
\text { lignin } 3\end{array}$ \\
\hline 0 & 0 & 0 & 0 & 0 & 0 & 0 & 0 \\
\hline 12 & 166631 & 171183 & 176012 & 175487 & 195262 & 192358 & 185969 \\
\hline 24 & 67416.6 & 60267.8 & 70660.6 & 76671.1 & 52398.5 & 53682.1 & 52566.6 \\
\hline 36 & 35795.1 & 34738.1 & 37028.6 & 31639.2 & 28958.1 & 28995.4 & 26884.1 \\
\hline 48 & 39486.1 & 24001 & 27197.1 & 23627.5 & 24482 & 26629.7 & 27078.6 \\
\hline 72 & 27118 & 22740.5 & 29615.8 & 24227.2 & 24290.5 & 24060 & 33008.4 \\
\hline 96 & 16498.6 & 16549.9 & 19375 & 14432.2 & 13795.9 & 13108.3 & 15880.2 \\
\hline 144 & 14010.4 & 12824.2 & 13691.4 & 12158.6 & 12832.8 & 12790.1 & 16590.4 \\
\hline 192 & 8879.2 & 8248.95 & 8623.64 & 8287.09 & 7475.96 & 7875.98 & 8742.67 \\
\hline 240 & 5942.15 & 6237.55 & 6058.79 & 6014.77 & 5894.23 & 5949.57 & 6014.96 \\
\hline \multicolumn{8}{|l|}{$\begin{array}{c}\text { Degraded } \\
\text { newsprint } \\
1-d\end{array}$} \\
\hline & DNP 1 & DNP 2 & DNP 3 & DNP 4 & $\begin{array}{c}\text { DNP } \\
\text { lignin } 1\end{array}$ & $\begin{array}{c}\mathrm{DNP} \\
\text { lignin } 2\end{array}$ & \\
\hline 0 & 0 & 0 & 0 & 0 & 0 & 0 & \\
\hline 12 & 158963 & 166895 & 150594 & 158744.5 & 166976 & 179270 & \\
\hline 24 & 66373.7 & 55863.3 & 68101.2 & 62983 & 55626 & 51617.3 & \\
\hline 36 & 34408.6 & 41392 & 38273.9 & 39895 & 38494.2 & 23655.2 & \\
\hline 48 & 30008 & 27100.3 & 28706.9 & 27913 & 19956.1 & 19909.8 & \\
\hline 72 & 30566.5 & 33988.9 & 31445.3 & 32767 & 35828.7 & 32010.5 & \\
\hline 96 & 15108.8 & 17182.84 & 16308 & 19745 & 20586 & 20511.4 & \\
\hline 144 & 13700.4 & 18399.6 & 14306 & 16753 & 20016.7 & 20102.9 & \\
\hline 192 & 9177.33 & 11841.9 & 9540.81 & 10791 & 9071.31 & 8942.31 & \\
\hline \multicolumn{8}{|l|}{$\begin{array}{l}\text { Degraded } \\
\text { office } \\
\text { paper } 1-d\end{array}$} \\
\hline & DOP 1 & DOP 2 & DOP 3 & DOP 4 & $\begin{array}{c}\text { DOP } \\
\text { lignin } 1\end{array}$ & $\begin{array}{c}\text { DOP } \\
\text { lignin } 2\end{array}$ & \\
\hline 0 & 0 & 0 & 0 & 0 & 0 & 0 & \\
\hline 12 & 141146 & 140055.5 & 140754 & 139357 & 230704 & 229237 & \\
\hline 24 & 69450.1 & 78334 & 79302.5 & 77365.5 & 46755.3 & 48031.6 & \\
\hline 36 & 43930.5 & 43814.55 & 44944.3 & 42684.8 & 15714.4 & 15828.7 & \\
\hline 48 & 28993.3 & 27111.35 & 27079.9 & 27142.8 & 6528.56 & 6395.85 & \\
\hline 72 & 30219.5 & 30612.8 & 31405.8 & 29819.8 & 13503.6 & 13291.2 & \\
\hline 96 & 21271.1 & 20607.25 & 20543.8 & 20670.7 & 6794.61 & 7336.82 & \\
\hline 144 & 20118 & 20389.85 & 20551.5 & 20228.2 & 7933.85 & 7725.6 & \\
\hline 192 & 10842.2 & 12660.65 & 11658.1 & 13663.2 & 5812.11 & 5070.88 & \\
\hline
\end{tabular}




\begin{tabular}{|c|c|c|c|c|c|c|c|}
\hline 240 & 8392.46 & 8969.28 & 8848.57 & 9089.99 & 5013.21 & 4865.75 & \\
\hline $\begin{array}{c}\text { Newsprint } \\
30 \text {-d }\end{array}$ & & & & & & & \\
\hline Time (hr) & NP 1 & NP 2 & NP 3 & NP 4 & $\begin{array}{c}\text { NP } \\
\text { lignin 1 }\end{array}$ & $\begin{array}{c}\text { NP } \\
\text { lignin 2 }\end{array}$ & $\begin{array}{c}\text { NP } \\
\text { lignin 3 }\end{array}$ \\
\hline 0 & 0 & 0 & 0 & 0 & 0 & 0 & 0 \\
\hline 12 & 127907 & 135533 & 145491 & 137372 & 118246.2 & 108001 & 123706.2 \\
\hline 24 & 63535.3 & 65535.6 & 64545.7 & 58349.1 & 64757.29 & 74346.53 & 60184.82 \\
\hline 36 & 29663.9 & 26156.6 & 26389.4 & 27976.7 & 41531.22 & 34278.82 & 39628.76 \\
\hline 48 & 22570.8 & 23809.1 & 22608.6 & 20101.1 & 26853.77 & 21572.92 & 20642 \\
\hline 72 & 29296.8 & 28519.8 & 27895.5 & 27320.1 & 30881.24 & 34189.49 & 32449.63 \\
\hline 96 & 18633.6 & 18117 & 17583.4 & 17631.5 & 22915.24 & 22596.31 & 20542.74 \\
\hline 144 & 22158.8 & 23011.9 & 23322 & 21950.3 & 22299.45 & 25715.19 & 26292.45 \\
\hline 192 & 15568 & 15391.9 & 14506.2 & 14654.8 & 12797.06 & 9432.782 & 12440 \\
\hline 240 & 6600.63 & 7798.71 & 6704.03 & 8359.83 & 8109.795 & 5914.393 & 8888.568 \\
\hline 288 & 3488.91 & 4477.71 & 3697.3 & 2564.1 & 5990.534 & 4566.461 & 6673.185 \\
\hline & & & & & & & \\
\hline
\end{tabular}




\section{Appendix C Relationship between optical density and CFU}

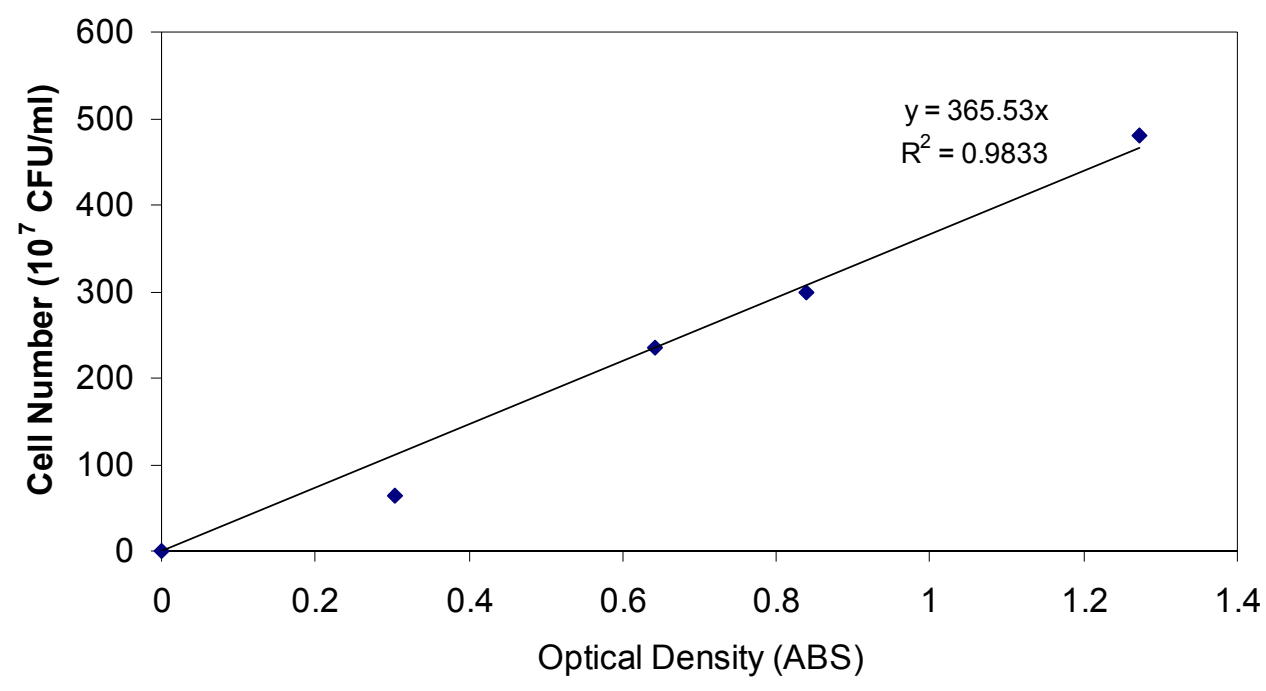

FIGURE C.1 Relationship between CFU and optical density.

CFU was measured by series dilution and plate count. Optical density was measure by spectrophotometer.

\section{Appendix D SAS code for statistical analysis}

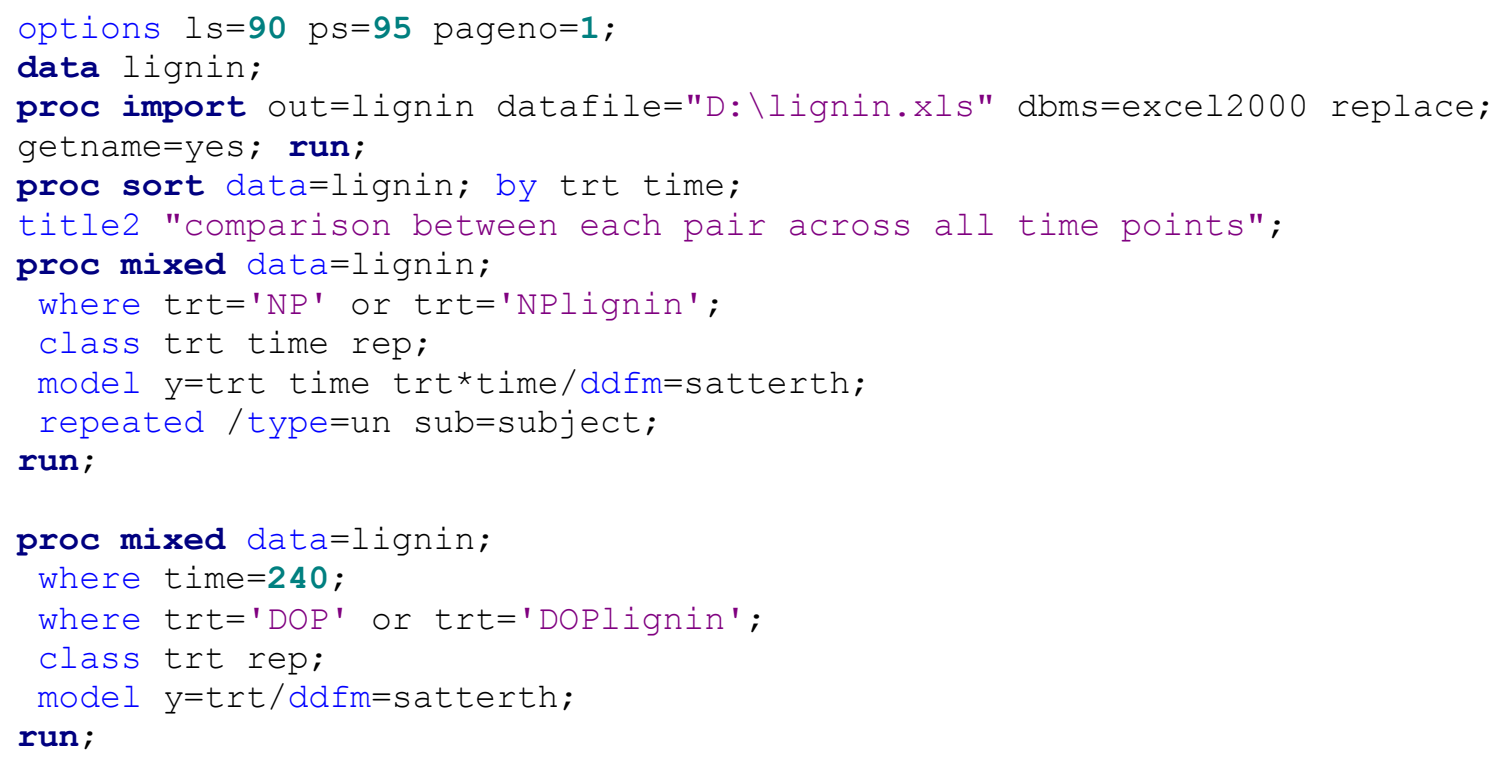

